\title{
DEMOCRATIC TRANSIT IN TERMS OF SECURITY AND DEVELOPMENT: UKRAINIAN AND FOREIGN EXPERIENCE
}

\author{
Collective monograph
}

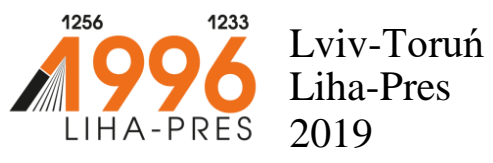




\section{Reviewers:}

Prof. dr hab. Sabina Grabowska, Uniwersytet Rzeszowski / University of Rzeszow (Republic of Poland);

Prof. $d r$ hab. Joanna Marszatek-Kawa, Uniwersytet Mikołaja Kopernika $w$ Toruniu / Nicolaus Copernicus University (Republic of Poland).

Democratic transit in terms of security and development: Ukrainian and foreign experience : collective monograph / L. I. Kormych, A. I. Kormych, T. M. Krasnopolska, Yu. V. Zavgorodnya, etc.; ed. by L. I. Kormych. - Lviv-Toruń : Liha-Pres, 2019. - 296 p. ISBN 978-966-397-158-2

The monograph reveals the multifaceted and multidimensional process of democratic transit. The specific sections focus on the priority problems of modern democracy.

Creating a secure space for the existence and development of states is analyzed as a guarantee of the success of democratic transformations.

The essence of security in the context of the hybrid nature of political processes is characterized. The specifics of conflicts in the modern world are highlighted. The peculiarities inherent in the legal, political, cultural, ethno-national dimensions of democratic transit are investigated. The basic signs of democratization on the examples of Ukraine and some foreign countries are clarified.

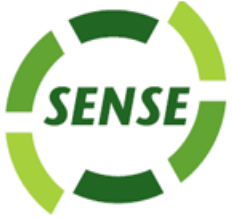

Liha-Pres is an international publishing house which belongs to the category „C» according to the classification of Research School for Socio-Economic and Natural Sciences of the Environment (SENSE) [isn: 3943, 1705, 1704, 1703, 1702, 1701; prefixMetCode: 978966397]. Official website www.sense.nl. 


\section{CONTENTS}

SECURITY AS A DETERMINANT OF DEMOCRATIC TRANSFORMATION: THREAT PARAMETERS AND EVALUATION CRITERIA

Kormych L. I. 1

EXPANDING THE SECURITY CONTENT IN MODERN CONDITIONS AND SPECIFICS OF ITS PROVISION

Kormych A. I. 21

INFORMAL DESTRUCTIVE POLICY PRACTICES AS A FACTOR OF INFLUENCE ON DEMOCRATIC POLITICAL TRANSIT Krasnopolska T. M 41

CONFLICT FACTORS IN A TRANSIT SOCIETY

Zavgorodnya Yu. V. 67

THEORETICAL BACKGROUND OF THE RESEARCH OF THE TRANSITION TO DEMOCRACY PROCESS

Myloserdna I. M. 83

DEMOCATIC CHANGES AND A HYBRID REGIME:

A THEORETICAL ANALYSIS

Dziubenko Yu. M. 103

POLITICAL DIALOGUE - A KEY TOOL

FOR PROVIDING DEMOCRATIC TRANSIT

Pielievin I. Yu.

POLITICAL RISKS AS A SOCIO-POLITICAL PHENOMENON

IN THE ASPECT OF MODERNIZATION OF THE

POLITICAL PROCESS

Pekhnyk A. V. 135

INTRA-PARTY RESTRUCTURING IN THE CONDITIONS OF POLITICAL TRANSIT IN UKRAINE Kroitor A. V. 
FEATURES OF POLITICAL STABILITY IN UKRAINE IN THE CONDITIONS OF POLITICAL TRANSIT

Kozminykh A. V. 175

TRANSFORMATION OF POLITICAL CULTURE IN THE SOCIO-CULTURAL CONTEXT OF UKRAINE

Sushko A. I. 191

FEATURES OF ETHNO-NATIONAL POLITICS IN THE COUNTRIES OF CENTRAL AND EASTERN EUROPE Vitman K. M.

SYMBOLIC ATTRIBUTION OF STATE SOVEREIGNTY

AS A FACTOR OF POLITICAL TRANSIT:

THE POST-SOVIET EXPERIENCE

Mamontova E. V. 225

PROTEST SOCIO-POLITICAL MOVEMENTS

AND ORGANIZATIONS AND THEIR TRANSFORMATION

IN THE LATE 1980S. IN THE MODERN COUNTRIES

OF THE VISEGRAD GROUP

Koltsov V. M.

IMPACT OF CRIMEA'S ANNEXATION ON SECURITY POLICIES IN EUROPE: ADDRESING CHALLENGES AND MANAGING VULNERABILITIES BY THE EU AND VISEGRAD GROUP Dvornichenko D. 271 
DOI https://doi.org/10.36059/978-966-397-158-2/1-20

\section{SECURITY AS A DETERMINANT OF DEMOCRATIC TRANSFORMATION: THREAT PARAMETERS AND EVALUATION CRITERIA}

\section{Kormych L. I.}

\section{INTRODUCTION}

Understanding security as a state of protection for the vital interests of the individual, society, state and world community determines its special role in the process of democratic transformation. This, in turn, necessitates the analysis of security threats, specifying each actor and object, as well as evaluating the effectiveness of models and mechanisms for preventing or overcoming threats. The perspective modeling of security processes and the prediction of possible security threats in an era of global change should be multidimensional. In fact, the degree of effectiveness of such models and the effectiveness of the mechanisms of their implementation determines both the possibility and the time frames of creating a secure environment for successful implementation of democratic reforms. This process, with certain limits due to national peculiarities, is based on the laws that determine the phenomenon of globalization. Priority is given to the category of security threats in the analysis of security status and the creation of normal conditions for the existence and functioning of entities of different levels. Determining the nature of the threats requires an awareness of their specificity, which is conditioned by both the entity causing the dangerous conditions and the object targeted by those threats. This should take into account the circular cause and effect relationship between the actor and the object, which can change the place in the security structure according to the role function. Thus, the paper tends to focus on the current challenges and new trends in security in the current context in terms of structural and factor tectonics, highlighting their main parameters.

\section{Basic parameters for security threats}

The approach adopted hereby is based on conclusions that specificity of the threat parameters is determined by the nature and place, which the particular threat source or its potential object posses in the security system. Thus, by acting as a security threat, a person can become an actor in terrorist 
activity, including becoming a member of international terrorism as a threat to both national and international security. This requires significant restrictions and increased accountability at the legislative, managerial and social levels with respect to a person in order to prevent him or her from participating in such acts or to stop unlawful criminal activity that is threatening to the safety of other entities. And when a person is the target of threats, the other person's target is another: to have a system of protective and stimulating measures for guarantees of human rights and freedoms and their realization.

The subjective role of society as a carrier of threats is related to the spread of aggressive moods, impatience and intolerance in relations with other actors. Hence the need for information and psychological influence on society, education and upbringing for the sake of correlation or change of mass consciousness, reduction of aggressive intentions and introduction of a tolerant model of social behavior. For society as an object of threats, it is about solving a complex of problems of improving the quality of material and spiritual development, preventing decline in quality and standard of living, preventing stagnation or degradation.

The state as a subject of threats is a source of violent, repressive actions in domestic and foreign policy, which are the bearer of genocide, war, mass terror and so on. In this case, there is an urgent need for severe restrictive measures by the international community in the form of various sanctions, coercion to peace, peacekeeping operations and other forms of cessation of aggression by individual states. The problem is also the loss of the monopoly on the use of force by the state, which significantly expands the range of use of violent methods both in the domestic and in the foreign state. The objective role of the state requires evaluation of the effectiveness of the mechanism for ensuring its sovereignty and integrity.

In the context of threats to the world community, the pace of progressive civilization progress, the elimination of inequalities in geopolitical processes, the prospects of inter-civilizational dialogue, and the introduction of a consensus model of international relations to preserve civilization and further improve it, should be analyzed.

However, the nature of contemporary civilizational, political, and economic clashes causes a wide range of potential threats. And it is precisely this multidimensional and ambiguous nature of the contradictions that arise within the various global and national processes of social development that is the object of scientific analysis in the works of many leading theorists, such as: J. Attali, R. Aron, P. Gauder, S. Huntington, O. Spengler, F. Fukuyama and other authors, who analyzed, simulated and predicted the development of modern world processes that are important for understanding the complex of security problems 
of existence and the functioning of their subjects in different aspects - political, economic, legal, etc. ${ }^{1}$.

For a considerable time, the focus of security researchers was on issues of military and political nature: war, arms race, nuclear weapons and other weapons of mass destruction, terrorism. Today, however, convincingly proves the need, and often the priority, of solving a complex of other important issues of social life. This applies to various areas: law, economics and finance, energy and information, health or the environment, criminal business (drug trafficking, human trafficking), national and religious relations, and so on. These issues, both important and costly, require considerable concerted effort. Therefore, public opinion is forming an understanding of the growing importance of non-military threats and the need to address them in the security plane. It is this wide range of threats that characterizes the multidimensionality of the security category, determines its components and, accordingly, the factors influencing them. The globalization of threats also requires the globalization of their prevention. This is addressed by a set of diplomatic efforts, institutional restructuring of the system of international relations, improvement of legal regulation in various spheres of activity.

An important place in today's world is environmental safety. Environmental pollution, lack of natural resources, drinking water; Earth erosion, «ozone holes», «greenhouse effects», environmental disasters as a result of large-scale natural disasters or technological failures, or the deliberate destruction of environmentally hazardous objects are often regarded as threats, levels, and sometimes more powerful in their adverse effects than the military. Preventing and addressing environmental threats is extremely costly and, according to various estimates, totals up to $\$ 425$ billion, while the global community spends three times less on these needs, which is not enough to overcome such threats.

Epidemiological safety is close to this aspect - the spread of AIDS, «bird flu», Ebola, other dangerous and practically incurable diseases for the given period. Annual challenges to these complex tasks are up to $\$ 15$ billion,

\footnotetext{
${ }^{1}$ Attali J. Millennium; Winners and Losers in the Coming Order. New York. Three Rivers Press. 1992. 135 p.; Aron R. Paix et guerre entre les nations, 8e éd. Paris. Calmann-Lévy, Pérennes, 2004. 749 p.; Fukuyama F. State Building: Governance and World Order in the Twenty-First Century. London: Profile Books Ltd, 2004. 256 p.; Fukuyama F. The End of History and the Last Man. New York: Simon and Schuster, 2006. 432 p.; Gowder P. The Rule of Law in the Real World. New York: Cambridge University Press, 2016. 288 p.; Huntington S. P. The Clash of Civilizations and the Remaking of World Order. New York: Simon \& Schuster, 2011. 368 p.; Spengler O. The Decline of the West. Ed. A. Helps, and H. Werner. Trans. Ch. Atkinson. New York: Oxford University Press, 1991. 480 p.
} 
while real costs do not exceed $\$ 2$ billion ${ }^{2}$. The vast majority of countries affected by these diseases have absolutely no ability to address these issues on their own without international assistance, because, for example, the health budget of a country like Ethiopia, with a population of 105 million, is only $1 \%$ of the richest man of the world - the owner of the Amazon company Jeff Bezos with a fortune of 112 billion dollars, according to the international organization Oxfam, prepared for the forum in Davos, held in January $2019^{3}$.

The development of technology and industry is accompanied by the likelihood of large-scale man-made disasters of chemical, radiological, bacteriological nature, which negatively affects both nature and man.

The depletion of the Earth's natural resources causes a shortage of fuel, energy, and food, posing a threat to human existence itself.

All this stimulates the search for alternative sources of the resource base and optimization of its use, requires the identification of ways to solve a complex set of problems that are vital for humanity in general and specific countries, in particular.

The central actors in the process of ensuring non-military security are states, their governments, intergovernmental organizations. But in this area, the «private sector» of the world community also plays a significant role: national and transnational businesses, national and international public organizations, which put pressure on governments and help them solve pressing problems.

Security threats are also posed by transnational criminal processes (nonpolitical violence) - illegal migration, drug trafficking, human trafficking, hacking, corruption, money laundering. Today it is the uncontrolled illegal mass migration and cybercrime that are becoming especially widespread as security threats, requiring new ways of preventing and overcoming them. Primitive bans and restrictions in these areas are ineffective and can themselves threaten the implementation of human rights legislation or the advancement of new technologies. And a certain balance of permits and prohibitions is important, which stimulates the development of positive trends.

There are problems related to the threat of overpopulation and uneven settlement, which in turn causes problems with the provision of food, water and energy resources. During the second half of the twentieth century, the

\footnotetext{
${ }^{2}$ World health statistics 2016: monitoring health for the SDGs, sustainable development goals. World Health Organization, 2016. 136 p.

3 Public Good or Private Wealth? Oxfam Briefing Paper - January 2019. Oxfamilibrary.openrepository.com: website. URL: https://oxfamilibrary.openrepository.com/ bitstream/handle/10546/620599/bp-public-good-or-private-wealth-210119-en.pdf.
} 
Earth's population doubled, reaching over 7.3 billion. At the same time, in Europe it increased by 1.5 times, and in Africa by 3.3. For example, a population estimate of a country such as Nigeria is estimated at 750 million as of 2100. For comparison, the total population of countries much larger than the European Union is now just 500 million. ${ }^{4}$. Thus, according to the Chinese National Bureau of Statistics, its population grew by 6.6 million in 2018, amounting to 1,427 billion. ${ }^{5}$ Whereas in Ukraine according to the state statistics the population in 2018 decreased by almost 200 thousand people ${ }^{6}$. Such uneven population growth calls for new approaches to the pace and direction of economic development and to the distribution of vital values. Only overcoming hunger alone, food security needs up to $\$ 260$ billion, affecting over 821 million people, or every ninth inhabitant of the planet ${ }^{7}$. This is due to the enormous inequality of wealth when, according to Oxfam, prepared for the World Economic Forum in Davos in 2018, the wealth of just 26 of the world's richest people equals the wealth of 3.8 billion of the world's poorest ${ }^{8}$.

Therefore, any non-military sphere is important and costly and requires a concerted effort to create the safe conditions for the existence of a variety of subjects, from the individual and to humanity as a whole.

Although most theoretical justifications for security are threats to the state, they are expanding the subject field of security of the concept of «human security». After all, security measures are designed to protect both states and citizens from external and internal threats, both military and nonmilitary. Over the past 100 years, a far greater number of people in the world have died, not from the fighting of foreign armies, but from the consequences of the erroneous or ineffective policies of their own governments. The list of major threats to human security should include famine, epidemics and natural disasters that take far more lives than wars and terrorism together.

42016 World Population Data Sheet. Population Reference Bureau: website. URL: http://www.prb.org/Publications/Datasheets/2016/2016-world-population-data-sheet.aspx.

${ }^{5}$ Population of China 2018. Worldometers - real time world statistics: website. URL: https://www.worldometers.info/world-population/china-population/.

${ }^{6}$ Чисельність населення (за оцінкою) на 1 грудня 2018 року та середня чисельність у січні-листопаді 2018 року. Офіційний сайт Державної служби статистики Украӥни. URL: http://www.ukrstat.gov.ua/operativ/operativ2018/ds/kn/xls/kn1118_u.xls.

${ }^{7}$ The State of Food Security and Nutrition in the World 2018. Building climate resilience for food security and nutrition. Rome, 2018. 202 p. The Food and Agriculture Organization of the United Nations: website. URL: http://www.fao.org/3/I9553EN/i9553en.pdf.

8 Public Good or Private Wealth? Oxfam Briefing Paper - January 2019. Oxfamilibrary.openrepository.com: website. URL: https://oxfamilibrary.openrepository.com/ bitstream/handle/10546/620599/bp-public-good-or-private-wealth-210119-en.pdf. 
In many cases, it is the realization of non-military threats that creates the conditions for the emergence and materialization of threats of a military nature and without neutralizing the former it is impossible to combat successfully the latter. Therefore, the UN peacekeeping concept offers a comprehensive approach to addressing both military and non-military threats.

There is an alignment of the priorities of the various spheres of «broad security». Military security somewhat loses its former almost monopoly position of «high politics». At the top of the world engagement agenda, it is cramped by those non-military problems that were previously unconditionally attributed to the category of «low politics».

This transformation is due to a number of objective processes: the growth of the well-being of mankind, the possibility of new technologies to combat non-military threats, the collapse of illusions to «shield» from the negative effects of the disadvantaged part of the world, the expansion of the collective efforts to counter transnational threats, which are globally related; improving security in the military sphere.

In spite of all the problems of confrontation in modern conditions, there was a change in the algorithm of «balancing on the brink of war» and «mutually assured destruction». The likelihood of a nuclear missile strike has declined dramatically, even with the demonstration of nuclear efforts by Iran or North Korea and uncertainty about the real results of reaching a nuclear threat reduction agreement, for example, in the 2018 negotiations between the US, South Korea and North Korea; or despite statements by some Russian officials about the possibility of being transformed into US ash. The end of bipolar confrontation has helped to reduce military spending. In its midst, humanity spent $8.2 \%$ of the world's gross product on military needs, and today it accounts for about $3 \%$. Although this trend has certainly not become entrenched in world politics and, in particular, Russia's aggression against Ukraine has forced European countries to address the issue of increasing military budgets, and some positive developments have already taken place.

For example, the arsenals of weapons of mass destruction, heavy conventional weapons, the number of armed forces, and the volume of arms trade have declined significantly. Full-scale wars between the states have gone. However, forms of political crisis such as local wars, frozen conflicts, and the modern kind of hybrid wars require raising the issue of increased military spending and strengthening military capabilities, including the growing number of armies and expanding military presence. The outbreak of armed conflict occurred in the early 1990s and into the first decades of the 21 st century, caused by the destruction of the bipolar world and geopolitical 
change. And even though wars become less bloody for a certain period, they remain a real threat to human life as the highest value. Thus, according to the 2005 Human Security Report, there was a significant decrease in the intensity of armed conflict, such as the number of combat casualties per year. In 1950, the figure was 38,000 deaths a year in one military conflict, and in 2002, 600 people. ${ }^{9}$. But, as the authors of this research point out, combat casualties give a comprehensive idea of the lethality of combat alone. At the same time, war kills people in less direct but predictable ways, especially when it destroys the economy of society, the infrastructure of medical or social services, public security systems, etc.

In addition, there is now a tendency to increase the mortality rate of armed conflicts. For example, the number of casualties of the unleashed Russian Federation in the East of Ukraine in the conflict from March 2014 to March 2017 alone among the servicemen of the Armed Forces of Ukraine and other security agencies amounted to 2629 dead and 9453 wounded $^{10}$. And these numbers are constantly increasing, because the fighting does not stop. The Fifth President of Ukraine P. Poroshenko, speaking on February 19, 2019 in the Verkhovna Rada of Ukraine, named 2949 dead during the armed aggression of the Russian Federation by Ukrainian servicemen ${ }^{11}$. Human casualties are compounded by the deaths of missing persons, as well as casualties among civilians adjacent to the line of contact. According to the statement of the Ministry of Foreign Affairs of Ukraine on February 20, 2019, the number of victims of the armed confrontation of the Russian Federation during the 5 years is about 13,000 dead and more than 30,000 wounded, nearly 1.5 million people have been displaced ${ }^{12}$. As a result, Ukraine's military expenditures have almost doubled and the number of our country's armed forces has increased. Today, Ukraine is forced to anticipate defense spending at 5\% of GDP. Similar was the reaction of European countries to the growing threat of military conflict. Governments of European countries, USA resolve issues of increase of financing of

\footnotetext{
${ }^{9}$ Human Security Report 2005: War and Peace in the 21st Century / ed. A. Mack. Oxford: Oxford University Press, 2005. P. 31.

10 Лысенко: С начала АТО погибли 2 тыс. 629 украинских военных. 112 Украина: веб-сайт. URL: http://112.ua/ato/lysenko-s-nachala-ato-pogibli-2-tys-629-ukrainskih-voennyh378916.html.

11 Виступ Президента під час спеціального засідання Верховної Ради у зв'язку 3 5-ю річницею з початку збройної агресії Росії проти України. 19 лютого 2019 р. Офіuійне інтернет-представництво Президента України: веб-сайт. URL: https://www.president.gov.ua/ news/vistup-prezidenta-pid-chas-specialnogo-zasidannya-verhovnoyi-53254.

12 Заява МЗС України 3 приводу 5-х роковин початку збройної агресії Росії проти України. 20 лютого 2019 р. Офіційний сайт Міністерства закордонних справ Украӥни. URL: $\quad$ https://mfa.gov.ua/ua/press-center/news/70583-zajava-mzs-ukrajini-z-privodu-5-khrokovin-pochatku-zbrojnoji-agresiji-rosiji-proti-ukrajini.
} 
military-defense complex, number of military presence of NATO, etc. At the NATO Summit in July 2018, there was a commitment to finance at least $2 \%$ of GDP from each Alliance member. In other words, as a result of the spread of armed conflict, economic losses of states increase, supplementing human losses and adversely affecting all processes of democratic development.

Undoubtedly, in the beginning of the 21 st century the total number of victims of all kinds of mass violations of human rights in general decreased.

The only exception is terrorism. The number of large-scale terrorist acts is increasing, there is an increase in the psychological and economic damage caused by them, the cost of combating terrorism is increasing. Although it can be noted that the number of victims of terrorism is less than one percent of the total world casualties from political violence, this trend in military security is unstable. The results achieved do not give rise to euphoria, as every terrorist act robs dozens and hundreds of lives at the same time. And such events take place in the most different countries of the world, on all continents. In 2017-2018 alone, terrorist acts were committed by radical extremist groups of different directions in the United Kingdom, France, Turkey, Sweden, Norway, Pakistan, Afghanistan and several other countries in different parts of the world, taking in each case tens and hundreds of human lives. Therefore, the results of public opinion polls indicate a concern for the state of the world military security itself as a way to protect against terrorist threats.

Partially similar sentiments can be explained by purely subjective reasons. For example, the media focuses on the threats that remain, ignoring the positive developments that have taken place. Attention is drawn to conflicts that start tragically, not those that are peacefully settled, as the threat picture has a greater impact on readers and viewers, widens the reach of potential users and consumers of information, promotes media promotion. It does not bring dividends with a balanced comparative analysis of the past and present security situation and politicians who are afraid to look in the eyes of voters are not sensitive enough to today's threats. Sometimes, security threats are artificially inflated to achieve other goals. But the main reason is the growing demand on the part of the world community for security, both military and non-military, and the lowering of the threshold of tolerance for violations. This raises particular interest in security issues from various political actors.

However, as non-interconnected security areas, they remain specific in nature of threats and means of counteraction to them. And such specifics should not simply be taken into account, but the particularities should be the focus of research in order to find effective ways to solve complex problems. For example, ensuring environmental security requires means, tools and 
political and legal mechanisms other than those needed to resolve inter-state armed conflicts or to combat terrorism. The algorithms for the operation of different security areas are unique. They are combined by a common negative impact, and often a deadly effect on the combined security of the individual, country, region and the entire global community. But a comprehensive approach to security should not negate the features of each of its components. It is the specificity of individual subsystems that creates a multidimensional, non-linear vision of the current state of security. This takes into account the various features of the security process with all its components and in different dimensions and aspects. All this allows predicting the behavior of the entire security system and setting up basic criteria for evaluation its status.

\section{Criteria for assessing the state of the security system and its components}

The main criterion for assessing the security situation is the stability indicator, both internal and external. After all, stability is the meaning of the functioning of security mechanisms, without excluding the dynamics of processes and change of forms.

Stability studies cover a wide range of problems, from the absence of war to the evaluation of integrative interaction, from the invariance of structures to the analysis of their dynamic models. They can be divided into two groups. For the first group, the initial postulate is the strong link between the stability of international systems and the configuration of their structures. And within the second, stability is characterized in the abstract, defining the conditions for maintaining stability in any structured system. The first group includes the works of L. Geddis L. Miller, K. Waltz, and others ${ }^{13}$; to the second one - K. Boulding, T. Schelling, O. Bogaturov and others ${ }^{14}$. All of these studies have broadened the theoretical understanding of stability by analyzing it as a systemic parameter of security and finding the difference between static and dynamic measurements of stability.

Stability and development mechanisms have been identified as autonomous, linked to different components of the system that require

\footnotetext{
${ }^{13}$ Miller L. Global Order. Values and Power in International Politics. Boulder: Westview Press, 1994. 269 p.; Waltz N. K. Theory of International Politics. Reading: Addison-Wesle, 1979. 251 p.; Gaddis J. L., The Cold War: A New History. New York: Penguin Press, 2005. 334 p.

${ }^{14}$ Boulding K. E. Conflict and defense: a general theory. New York: Harper \& Brothers, 1962. 349 p.; Schelling T. C. The Strategy of Conflict. Reprint, illustrated and revised. ed. Cambridge, MA: Harvard University Press, 1980. 309 р.; Современная мировая политика: прикладной анализ / Ред. А. Д. Богатуров. М.: Аспект Пресс, 2010. 592 с.
} 
different approaches to their study. The variability of such a study is due to the structural-genetic analysis of the object, which as a result constructs a number of theoretical models that describe the states of stability, or statistical parameters that characterize the interaction of structural elements of complex systems. It is particularly important to analyze the behavior of such systems in motion, that is, dynamic stability as a system parameter inherent in the modern multipolar world, which contributes to the restoration of the stability of the relations system between states and thus stimulates their internal stability. But this principle cannot be equated with the risk of achieving stability at any cost, sacrificing the stability of interests of particular states, concessions to power, etc. There are certain taboos fixed by the international legal norms and rules of civil interaction.

But interaction is most clearly manifested in conflict, so defining the notion of stability for international relations in one way or another included the problems of war and peace. They have completed the form in the works of American scientists K. Deutsch and D. Singer. By definition, stability is the likelihood that the system retains its basic characteristics and there is no large-scale war $^{15}$. Thus the absence of war was not an attribute, but one of the signs of systemic stability, its consequence. Understanding stability as a factor inherent in the international structure from the beginning is characteristic of neorealism. The configuration of the structure in the interpretation of the representatives of this current contains a factor that prevents states from taking action that threatens the very existence of the system and continuing to exist means stability. However, such an interpretation gives to the integral structure an overriding role in shaping the behavior of its elements, eliminating the possibility of influence of individual states on the configuration of the international structure. In this embodiment, stability acts as an attribute of the «general» and is independent of the action and interaction of the «special». Such logic narrows the notion of stability, introduces it into the framework of structural parameters of a holistic system only, and does not take into account the role of specific states in creating and maintaining the stability of the international system. This, in turn, underestimates the dynamics of change throughout the system as an adequate response to the positions of its individual elements. But the analysis of the current state of the system of international relations

15 Deutsch K., Singer D. Multipolar Power Systems and International Stability. In Analyzing International Relations: a Multimethod Introduction. Colpin W. (eds.). New York: Praeger, 1975. $321 \mathrm{p}$. 
convincingly proves that the mechanisms of maintaining stability lie in the plane of behavior of its individual elements. This tendency is confirmed by the criticism of current politicians and scholars of the place and role in the security of an institution such as the UN as a whole, or of the UN Security Council in particular, and the justification of the urgent need to reform them.

A definite solution to the contradiction in understanding the concept of stability is the definition proposed by O. Bogaturov. In his view, stability should be considered as a certain type of movement of the system of interstate relations, a movement relatively smooth, uniform and predictable, under which the system is able to exist, reproduce and change without losing its basic characteristics. Stability characterizes the ability of a system to provide the changes necessary for its self-preservation, compensating for them so that the loss of individual elements and characteristics does not pose a threat to the survival of the system as a whole ${ }^{16}$. Such a definition is based on the recognition of the dynamic nature of the system of interaction of states, on the understanding of the need to create safe conditions for their coexistence, which ultimately aims to stimulate the development of each individual state and provides for strengthening its own security as a guarantee of security of other subjects of international relations.

Therefore, the attention of theorists in the second half of the twentieth century, the comparison of stability mechanisms under conditions of transition from bipolar to multipolar world order was given. The works of D. Baldwin, K. Booth, B. Schmidt, L. Miller, L. Geddis and other authors were devoted to the problems of connection between the structure of the international system and its stability. They outline the main approaches to creating safe conditions for development. The first approach emphasized states' capacity for self-restraint to maintain stability and prevent destruction. However, the «collective goods» theory underlying this approach has drawbacks either due to the neglect of opportunities or the desire to reduce one's own losses. A clear confirmation of such contradictions is the current migration policy of European states, its ambiguous assessment and perception by governments and the societies of individual states. This is evidenced by the difficult talks between EU leaders at the Brussels summit on June 28, 2018, covering issues such as migration, security and protection, jobs, growth and competitiveness, innovation and C. 34 .

${ }^{16}$ Богатуров А. Великие державы на Тихом океане. М.: Конверт - МОНФ, 1997. 
digital technologies, etc. ${ }^{17}$ In such situations, the collective security system in many cases becomes ineffective, as demonstrated today by the UN Security Council, requiring changes that will stimulate the coherence of individual states' actions in order to overcome existing security contradictions and not to be held hostage by individual members overburdened.

The second approach pays more attention to national security features that must be taken into account at both interstate and supranational levels, influencing structural changes in the security system as a whole. After all, national security is a subsystem, a structural element of collective security in today's globalized environment.

National security is characterized by all the features of systematicity: integrity, interconnection, interaction of structural components, their coordination, subordination and so on. The concept of entirety expresses the integrity, self-sufficiency, autonomy and activity of objects. It characterizes their qualitative originality due to specific patterns of functioning and development.

Depending on the location of the source of the danger, national security is divided into two types - internal and external. Each type of security, each such subsystem, in turn, also acts as a system in relation to its components. That is, a certain structural hierarchy is built up.

The structure of a security system is a set of strong relationships and links between the elements that ensure its integrity. And the quality of the security system is determined by the elements themselves (subsystems) and their interaction. All components must be organically interconnected. Interaction is a category that reflects the processes of action of different components on each other, their mutual conditionality, change of state, interaction and creation of others.

The interconnections between elements, system levels, between subsystems can be different: constant and variable, necessary and random, stable and unstable, mutually stimulating, interacting and mutually exclusive.

Interaction is not only a joint and concerted action, but a kind of relationships and links between objects. Any interaction consists of two components: unity and the struggle of the parties involved, or their

7 European Council conclusions. 28 June 2018. Consilium: website. URL: https://www.consilium.europa.eu/en/press/press-releases/2018/06/29/20180628-eucoconclusions-final/. 
promotion, which is a form of unity but does not come down to it completely. The unity of the security system is manifested in the dynamic connection, the interdependence of its structural elements, the continuity of the components of the common security, the inability to achieve it through efforts in one area alone, notwithstanding the other components.

This dynamic link exists between all elements of the security system. At the same time, these elements are not equal in the general system. Their place and role are determined by the extent of external and internal threats.

The structural components of the security system include: actors and objects of the security system; views, goals, principles, concepts, security doctrines of various fields; legal rules governing relations in the field of ensuring each type of security; resources for providing specific types of security; the vital interests of society, the state and the individual as a reflection of their objective needs; information on the dangers and threats to the vital needs of the individual, society and the state; methods and ways of security activities and their results.

Functional components of the security system demonstrate the basic connections of structural components that arise in the process of its functioning. Among them are: organizational - implementation of a certain administrative action on the elements of the system with the aim of consistency of actions; communicative - establishing appropriate interaction between the structural components of the system in the course of its functioning through the transmission of information; constructive - the selection and modeling of action on the system at each stage of achievement of goals, as well as determining the features of activities to ensure a specific type of security in specific historical conditions; design, which includes programming and forecasting activities to achieve the goals of the system; epistemological - the accumulation and analysis of new knowledge about the security system and ensuring its functioning.

Thus, the system of security means a specially created in the country a set of interacting entities, their official views, concepts and doctrines, enshrined in the relevant legal norms, as well as the forces, means, methods and directions that guarantee the quality of the society, its structures and institutions in the parameters of the guarantee of existence and sustainability of development, by eliminating the dangers and threats, their prevention, warning and elimination.

Within the system of a particular type of security several large subsystems interact: institutional, regulatory, functional, information and 
communication, cultural and ideological, each of which has its own characteristics.

The institutional subsystem is the basis of the security system. This subsystem plays a key role in the security system; conditions are ensured to ensure the effectiveness of the security mechanism, forms of interaction with other national security subsystems, as well as international security systems. It is here that the purpose and directions of the functioning of this system are essentially determined through the outlined competencies of the individual elements.

As a security system is a social system, it includes a system of social interactions between individuals, society, the state and the international community and the conditions for preventing or eliminating the dangers and threats posed to the organization. The main elements of this social interaction are actors - carriers of activity, which are inherent in the ability to be an independent source of activity, to realistically and directly influence the course of events, to change reality, thereby to promote the security of man, society and the state and to guarantee their own security, respectively.

The part of the political organization of the society that is directly concerned with security in each of the spheres of life is the institutional actor: it defines the goals of security necessary for its attainment of ways, forces, means, forms and methods of activity; organizes their interaction, manages the security mechanism related to the creation and use of special means. It is, first of all, the state - the system-forming subject of security, in particular its bodies of legislative, executive and judicial power, as well as their specialized institutes, which ensure the security of a specific sphere of life activity.

Institutional actors are also non-state institutions - political parties, public organizations and socio-political movements.

The actors of the social spectrum are social groups, communities (ethnic groups, executions, society as a whole), individual citizens, etc. Social interaction of these entities takes place in all spheres of society.

It is these different actors who make decisions aimed at affirming the safe conditions of their existence and functioning. The implementation of such solutions creates a field of interaction between these actors. The subject of this interaction is the needs and interests of individuals, social groups, social communities and communities.

In today's context, it is necessary to take a comprehensive account of the possible consequences of decisions that are made in certain areas of life and 
affect security. Therefore, the effectiveness of the security system depends on the availability of communicative-managerial capability (or intelligence) of the system, its awareness, as well as the coherence of actions to prevent and counteract hazards and threats. It is in this complex that a modern system of systems is formed.

Intelligence of a security system means its ability to make and timely implement the most effective solutions to prevent, neutralize or eliminate appropriate means of emerging hazards and threats; for the development and implementation of sound policies designed both for the long-term perspective of supporting sustainable development and for operational intervention in situations capable of generating tension or instability in society.

Security awareness is the ability to receive, store and process information in a timely manner to detect and respond adequately to hazards and threats using the available means and capabilities.

An important subsystem of the security system is the cultural and ideological subsystem. Security ideology is a systematic set of ideas and views on the security of states and citizens. It contains the ideological basis of the content of the existence of the state and is based on the synthesis of the accumulated knowledge to ensure a decent life of people both in terms of national and international experience.

The objects of safety are the various spheres of life activity, in which both the people themselves and their technology and the social structures of society, the state are involved; and finally the environment. In other words, there are different components to a security system when viewed vertically or horizontally. These are interrelated and interdependent components, but their place, hierarchy, role are determined by a number of circumstances, among which priority is the nature of public relations, political structure, the volume of external and internal dangers.

In the current model of relations «person - civil society - state» the relations between the elements must be built according to a concrete scheme. In the first place should be the person as the main object and at the same time the main actor of security, which through mechanisms of democracy and institutions of civil society delegates the most important powers to the state, exercising public control over it, but without encroaching on the inalienable, recognized by all right. Such cooperation is carried out within the framework of the social partnership model, where everyone's capabilities work for a common purpose - security. 
For the state, in this context, the purpose of existence and development, the criterion of effectiveness is the real guaranteed rights and freedoms, quality and standard of living. Only in this sense the person is the highest value, the criterion for the welfare of society.

The state and civil society in such a system of interconnections act as a means of preserving this value and achieving the goal of development, but man is the main resource of the state for the protection of his own interests in form, but public in essence.

Thus, the main interest of the state is the comprehensive (physical, spiritual and intellectual) development of the individual. Protection of the constitutional order, sovereignty and territorial integrity of the state; establishment of political, economic and social stability; unconditional implementation of laws and support of law and order, development of international cooperation - effective ways of ensuring the main interest of the state - comprehensive development of personality.

Hence the ideal security model: as the highest value for the functioning of the national and international security system, a person delegates some of the authority to ensure his or her own security to civil society, society, in turn, the state; and the state, to some extent, to the international community. The interconnection of national, international and global security and their interdependence is built on this approach. But nevertheless, the state remains the center of the security mechanism at national, interstate and even suprastate levels.

Recognizing the state as the center of the political system, an instrument of power, we emphasize its ability to prevent, neutralize, localize, weaken, eliminate the dangers and threats to the political system, the territorial integrity of the country, and the life of its population.

In this sense, the security of the state acts as the basis for maintaining the life of the system, which characterizes the qualitative certainty in the parameters of the reliability of existence and sustainability of the state as a whole, and society as a whole and its individual citizens. The security of the state can be ensured by the existence of an effective mechanism for managing and coordinating all social forces of society, as well as effective institutions for their protection.

A sovereign phenomenon is also the safety of society, characterized by a number of features: opportunities for the free development of public life, the sphere of mass movements, parties, unions by conviction and any other attribute; the development of the collective function; implementation of 
compromise interaction between majority and minority; the ability to limit and overcome political alienation within a tolerant model of interaction; sustainable development and preservation of material and cultural values, progressive traditions; non-interference with the sphere of a person's personal life.

The safety of society is guaranteed by the presence of public institutions, norms, developed forms of social consciousness and culture, which allow to exercise the rights and freedoms of all population groups and to resist the actions leading to the split of society. Thus, the security of society is a quality state of social relations that ensures the progressive development of man and society in specific historical and natural conditions, guaranteeing the protection and extension of rights and freedoms, the realization of needs and interests.

When addressing the issues of security in the area of state security and public safety, we constantly cross the area of personal security of citizens, face human security, its position in society, the opportunity to live and work in proper conditions, to realize our material and spiritual needs. In this perspective, human security is a priority in the whole security scheme, characterized by a real guarantee of constitutional rights and freedoms, its access to health, education, and culture systems; opportunity to choose activities by vocation, social guarantees for compensation of labor costs, absence of violent forms of coercion, etc. The personal security is granted by public institutions and organizations, the state, a set of moral and national and international legal norms that allow it to develop and realize socially significant needs and interests without confronting the opposition of the state and society.

All this indicates that the criteria for assessing the security situation is to be different and directly related to the specific subject and security object involved in the process of democratic transit.

\section{CONCLUSIONS}

Thus, it can be concluded that since security is a systemic phenomenon, it has a number of constituent elements that reproduce the diversity of internal and external, essential and irrelevant, necessary and accidental connections and communications, stimulating modern forms of interaction that cover institutional, regulatory and procedural spheres. Such a holistic system vision provides for the possibility of a comprehensive analysis of national and international security systems and mechanisms for their 
provision in the aspect of the general characteristics of the basic parameters of the modern security structure and algorithms of functioning of different security areas, emphasizing on the basic criteria for the assessment of safety states. At the same time, the dynamics of forms are accompanied by qualitative changes in their substantive content, in accordance with changes in the conditions of existence and functioning and the emergence of new challenges and threats to the system as a whole or its individual elements. In this case, tectonics occurs both vertically and horizontally and requires the creation of new security models and the improvement of methods of providing it. Meeting these requirements becomes essential, because a sufficient security status appears the basic guarantee of a progressive democratic development in the modern world. This is especially important for countries in democratic transit whose democratic transformations have not been completed in order to prevent the threat of restoration of the undemocratic format of the state's existence and functioning. Ukraine belongs to this category, following the path of deepening democratic reforms that meets the public needs and demands. Therefore, security problems, especially in the face of aggression of the Russian Federation, are vital. Only safe living conditions may grant Ukraine's democratic progress. Meeting such conditions have a capacity to ensure the attractiveness of democratic transformations both for national society itself and for the external democratic environment.

\section{SUMMARY}

Security as a systemic phenomenon is a guarantee of successful democratic transformations, which determines the special role of this category in the analysis of the process of democratic transit. The security states of different actors: human beings, societies, states have a specific nature and characteristics whose understanding opens up opportunities for refining political strategies. The current era creates new security challenges and trends, requiring the creation of appropriate security models and mechanisms. The basic parameters of threats are caused by circular cause and effect interdependence between elements of the security system. The main criteria for assessing the security situation as determinants of the democratic transit process are due to the parameters of dynamic stability. Creating a safe environment ensures successful democratic progress in all spheres of life, both nationally and internationally. 


\section{REFERENCES}

1. Aron R. Paix et guerre entre les nations, 8e éd. Paris. Calmann-Lévy, Pérennes, 2004. 749 p.

2. Attali J. Millennium; Winners and Losers in the Coming Order. New York. Three Rivers Press. 1992. 135 p.

3. Boulding K. E. Conflict and defense: a general theory. New York: Harper \& Brothers, 1962. 349 p.

4. Deutsch K., Singer D. Multipolar Power Systems and International Stability. In Analyzing International Relations: a Multimethod Introduction. Colpin W. (eds.). New York: Praeger, 1975. 321 p.

5. European Council conclusions. 28 June 2018. Consilium: website. URL: $\quad$ https://www.consilium.europa.eu/en/press/press-releases/2018/ 06/29/20180628-euco-conclusions-final/.

6. Fukuyama F. State Building: Governance and World Order in the Twenty-First Century. London: Profile Books Ltd, 2004. 256 p.

7. Fukuyama F. The End of History and the Last Man. New York: Simon and Schuster, 2006. 432 p.

8. Gaddis J. L.,The Cold War: A New History. New York: Penguin Press, 2005. 334 p.

9. Gowder P. The Rule of Law in the Real World. New York: Cambridge University Press, 2016. 288 p.

10. Huntington S. P. The Clash of Civilizations and the Remaking of World Order. New York: Simon \& Schuster, 2011. 368 p.

11. Human Security Report 2005: War and Peace in the 21st Century / ed. A. Mack. Oxford: Oxford University Press, 2005. 170 p.

12. Miller L. Global Order. Values and Power in International Politics. Boulder: Westview Press, 1994. 269 p.

13. Population of China 2018. Worldometers - real time world statistics: website. URL: https://www.worldometers.info/world-population/chinapopulation/.

14. Public Good or Private Wealth? Oxfam Briefing Paper - January 2019. Oxfamilibrary.openrepository.com: website. URL: https://oxfamilibrary.openrepository.com/bitstream/handle/10546/620599/bp -public-good-or-private-wealth-210119-en.pdf.

15. Schelling T. C. The Strategy of Conflict. Reprint, illustrated and revised. ed. Cambridge, MA: Harvard University Press, 1980. 309 p.

16. Spengler O. The Decline of the West. Ed. A. Helps, and H. Werner. Trans. Ch. Atkinson. New York: Oxford University Press, 1991. 480 p.

17. The State of Food Security and Nutrition in the World 2018. Building climate resilience for food security and nutrition. Rome, 2018. 202 p. The 
Food and Agriculture Organization of the United Nations: website. URL: http://www.fao.org/3/19553EN/i9553en.pdf.

18. Waltz N. K. Theory of International Politics. Reading: AddisonWesle, 1979. $251 \mathrm{p}$.

19. World health statistics 2016: monitoring health for the SDGs, sustainable development goals. World Health Organization, 2016. $136 \mathrm{p}$.

20.2016 World Population Data Sheet. Population Reference Bureau: website. URL: http://www.prb.org/Publications/Datasheets/2016/2016world-population-data-sheet.aspx.

21. Богатуров А. Великие державы на Тихом океане. М.: Конверт МОНФ, 1997. $353 \mathrm{c}$.

22. Виступ Президента під час спеціального засідання Верховної Ради у зв'язку з 5-ю річницею з початку збройної агресії Росії проти України. 19 лютого 2019 р. Офіиійне інтернет-представництво Президента Украӥни: веб-сайт. URL: https://www.president.gov.ua/news/ vistup-prezidenta-pid-chas-specialnogo-zasidannya-verhovnoyi-53254.

23.Заява МЗС України з приводу 5-х роковин початку збройної агресії Росії проти України. 20 лютого 2019 р. Офіuійний сайт міністерства закордонних справ Украӥни. URL: https://mfa.gov.ua/ua/press-center/news/70583-zajava-mzs-ukrajini-zprivodu-5-kh-rokovin-pochatku-zbrojnoji-agresiji-rosiji-proti-ukrajini.

24. Лысенко: С начала АТО погибли 2 тыс. 629 украинских военных. 112 Украина: веб-сайт. URL: http://112.ua/ato/lysenko-snachala-ato-pogibli-2-tys-629-ukrainskih-voennyh-378916.html.

25. Современная мировая политика: прикладной анализ / Ред. А. Д. Богатуров. М.: Аспект Пресс, 2010. 592 с.

26. Чисельність населення (за оцінкою) на 1 грудня 2018 року та середня чисельність у січні-листопаді 2018 року. Офіщійний сайт Державної служби статистики України. URL: http://www.ukrstat.gov.ua/operativ/operativ2018/ds/kn/xls/kn1118_u.xls.

\section{Information about the author:} Kormych L. I., Doctor of History, Professor, Head of the Department of Political Theories of the National University «Odessa Law Academy» 2, Academichna str., Odesa, 65009, Ukriane 
DOI https://doi.org/10.36059/978-966-397-158-2/21-40

\section{EXPANDING THE SECURITY CONTENT IN MODERN CONDITIONS AND SPECIFICS OF ITS PROVISION}

\section{Kormych A. I.}

\section{INTRODUCTION}

The current stage of civilizational development focuses on the category of «security». World security issues become key issues discussed by the UN General Assembly in February 2019. And the issues of national security necessitated amendments to the Constitution of Ukraine made by the Verkhovna Rada on February 7, 2019. This dictates the need for real steps to create normal conditions for life and social development. It is in this perspective, for example, that the Budapest Memorandum of 1994 and its consequences for Ukraine can be evaluated, especially since 2014, following the aggression against Ukraine by one of the signatories to this memorandum - the Russian Federation. Such events confirm that security needs real guarantees, not populist promises. Legal acts must clearly define mutual commitments to support security, and effective institutional changes must take into account the particularities of the modern era and the hybrid nature of ongoing processes.

The practical importance of a wide range of security issues has determined the scientific interest in these issues, which have become the subject of analysis in the writings of many professionals. Thus, foreign authors, and at different times, in particular, N. Machiavelli, K. von Clausewitz, Q. Wright, A. Toynbee, F. Fukuyama, S. Huntington, others investigated conflicts or extreme states - wars, characterizing their place in social development. Many contemporary Ukrainian scientists, such as V. Gorbulin, O. Dzoban, G. Kostenko, V. Lipkan, O. Lytvynenko, G. Pocheptsov, A. Shevtsov, and others, analyze the current state of security by offering complex methods of its provision. However, the dynamics of the processes taking place in the world and in individual countries need to be given further attention to these problems, to analyze them from the point of view of expanding the subject field of security itself, and accordingly the nature of models and mechanisms for its provision. 


\section{The new security content in terms of the functioning of its individual modes}

In terms of content, in security, according to the spheres of activity (in horizontal section) there are the following types: political, economic, environmental, social, informational, spiritual, military and other.

The basis for constituting types of security is a set of objective and subjective prerequisites: the needs of people, social groups, society, state, international community to preserve and develop themselves and vital social and natural values and objects; expanding the range of hazards and threats, risks and challenges; awareness of the vulnerability of people, their vital interests; political and legal recognition and consolidation of security; availability of appropriate concepts, strategies, plans.

The continual expansion of security content in accordance with changes in human life conditions should be noted. Security is a multidimensional concept. However, the dynamics of the elements of its structure have a specific historical meaning and are linked to systemic changes. Therefore, the definition of diversity and priority of security is changing in time and space and serves multiple concepts, due to the different modes of operation of this system.

The main modes of functioning of the security system are traditionally determined by the following: peacetime, high readiness, state of emergency, martial law. These modes can be implemented nationwide, regionally or industry-wide. They may apply to both individual states and their associations and coalitions.

The operation of the security system in peacetime means the existence of normal conditions for the operation of security systems in the absence of threats to the national interests of countries, the needs of the unions of states and their practical implementation. In this mode, security entities carry out: work on forecasting, detection, risk assessment, prevention of their transformation into threats; neutralization of all kinds of threats to the national interests of the states or the interests and needs of the unions of the states; developing, approving and adjusting security plans and programs implemented in accordance with the procedure established by law in the event of a threat to national or inter-state interests; organizational support, including work on recruitment, training and improvement of personnel in various security spheres; control over the level and quality of implementation of strategic programs.

The operation of a security system on alert is its activity in the escalation of dangers and threats to national or interstate interests. Under this mode, security system operators take additional measures to eliminate the dangers, 
minimize the effects of their escalation, to prepare forces and means to counteract real and potential threats.

The presence of real threats to national or interstate interests despite prevention measures indicates the need for a security system to operate in a state of emergency. In such cases, mobilization of forces and a complex of means for counteracting and overcoming threats, either at the national or international levels, takes place to counteract the threats, localize and eliminate them.

A martial law is a kind of state of emergency, its radical form. It is about the realization of military threats that require the use of military force to neutralize and destroy them. In this mode of operation, the security system becomes, first of all, a system of military security. And in such circumstances, the introduction of a state of emergency or martial law for a certain period or in certain territories is possible, and sometimes necessary. These are the circumstances in Ukraine at the end of 2018 in the face of real aggression of the Russian Federation and escalation of threats in connection with the situation in the Sea of Azov, when 24 Ukrainian sailors illegally became prisoners of the Kremlin, which forced to enter a martial law regime for a limited period in a number of areas ${ }^{1}$.

Under all modes, security laws are manifested - the speed of response of security system actors to threats must exceed the speed of their formation and maturation, and the activity of these entities should be directed not simply to the cessation, localization, elimination and destruction of dangers and threats and, above all, to prevent and neutralize the causes that generate them, that is, to prevent the emergence of threats.

Therefore, the security system has a complex structure, each element of which has a specific meaning and performs specific functions to meet the relevant needs of existence and the effective functioning of the system. The normative nature of the relationship within this system is determined by clearly formulated tasks that it is intended to solve (the objective component), as well as the tasks that are imposed from the outside (the subjective component). A security system is a holistic, complex mechanism that interacts with other subsystems continuously. System security is manifested not only in the relationship between its elements, but also in the interaction of the system with the environment.

The concept of security system and system of security provision should be distinguished. The first is a functional system that reflects the processes

\footnotetext{
${ }^{1}$ Про введення воєнного стану в Україні: Указ Президента України від 26 листопада 2018 р. № 393/2018 (Указ затверджено Законом № 2630-VIII від 26.11.2018 із застереженням). Голос України. 28.11.2018. № 226.
} 
of interaction of interests and threats, and the second is an institutional system of bodies, forces, tools designed to solve security tasks.

An important prerequisite for ensuring the integrity and effectiveness of the security system is the proper definition and consideration of the organizational principles for its construction and operation. These may include principles such as: sufficiency focused on the adequacy of the system for foreseeable (potential) hazards and threats; optimality, which reflects the relevance of the security system and its costs to the real capabilities of states and societies; correlations that provide feedback and the ability of control entities to operate effectively at all levels and elements of the security system, with a view to improve them in the face of emerging threats and tasks that change over time and space; the coherence of actions of all actors and security forces, combined with the principle of responsibility for decisions made and the results and consequences of the process of their implementation.

These principles are particularly clearly manifested in extreme, radical situations that the security system is experiencing, especially in wars. At various stages of the history of mankind during the wars were resolved contradictions that have accumulated between the states; a new model and structure of international relations, consistent with the current political, economic and military balance was established; coalitions, alliances and blocs were adjusted. Military power was regarded as the most important component and factor in the strength of the state and the preservation of power. For a long time, the only one correct was the statement made by N. Machiavelli that A Prince ought to have no other aim or thought, nor select anything else for his study, than war and its rules and discipline; for this is the sole art that belongs to him who rules, and it is of such force that it not only upholds those who are born princes, but it often enables men to rise from a private station to that rank. And, on the contrary, it is seen that when princes have thought more of ease than of arms they have lost their states. ${ }^{2}$ That is, government and power were viewed solely through the lens of military success and were associated with the use of force and coercion in their radical format.

For a long time, the views of the war were dominated by the ideas of the German military theorist Karl von Clausewitz, in particular, in his preface to the treatise On War, that war was nothing more than a continuation of state policy by other means ${ }^{3}$. That is, wars were seen as a normal form of

\footnotetext{
${ }^{2}$ Machiavelli N. The prince. Translated with an introduction by H.C. Mansfield. 2nd ed. Chicago: The University of Chicago Press, 1998. P. 58.

${ }^{3}$ Клаузевиц К. О войне. В 2 т. Москва: АСТ. Санкт-Петербург: Terra Fantastica, 2002. T. 1. C. 11 .
} 
interaction of subjects in international relations. In doing so, von Clausewitz emphasized the social nature of armed conflict, noting that «war is an act of human communication». Accordingly, war refers «to the field of social life. It is a conflict of great interests, which is resolved by bloodshed, only in its last difference from other conflicts. «Politics, in turn, «is a war-bearing bosom; politics already contain the hidden features of war, just as the appearance of a living creature lies in its embryo» ${ }^{4}$.

Thus, in spite of the policy-based nature of the war, public policy is still largely related to military considerations. After all, an important task of foreign policy was the creation of favorable international conditions for the victory in future armed conflicts, first of all, through the creation of effective coalitions of their own.

The transformation of views on the war has certainly contributed to the most violent conflict in human history - World War II. The enormous human and material losses have led to a different look at war as a method of solving the problems of international relations. Thus, the English philosopher and historian A. Toynbee emphasized that war is essentially the result of the inability of a political solution to the conflict. He noted that war was «a physical test of power in which conflict of interest or difference of opinion is resolved by brute force. It would be closer to truth to say that war is a payback for the failure of diplomacy» ${ }^{5}$.

The recognition of the nonlinearity of the link between public policy and war as its instrument should be added, since war is the product of a complex set of objective and subjective factors. In particular, as early as 1942, American international scientist Q. Wright noted that «wars result from many combinations of changes in different relationships - technological, physical, sociological, and intellectual. There is no single cause of war. The world is balanced between many forces. Changes in some particular forces (trends, movements or political goals) may, in one case, lead to war, but in other circumstances, similar changes can lead to peace ${ }^{6}$.

On such ideological postulates in the second half of the twentieth century a negative attitude to the military means of conflict resolution began to form in the world politics, which contributed to the efforts of states to prevent a new world conflict, and the development of international legal instruments for conflict resolution, in particular within the UN, and the threat of a global war on the use of nuclear weapons, which would mean the end of

\footnotetext{
${ }^{4}$ Ibid. p. 163.

5 Toynbee A. J., Ikeda D. The Toynbee - Ikeda Dialogue: Man Himself Must Choose. Tokyo: Kadansha International, 1976. P. 186.

${ }^{6}$ Wright Q. A Study of War. In 2 vols. Chicago: University of Chicago Press, 1942. Vol. 2.
} P. 1284. 
civilization. Therefore, the emphasis shifted to the incentives for joint efforts on disarmament, restrictions on the use of military force, etc. Particular successes in the implementation of the new model of state interaction were achieved between the mid-1970s and the mid-1980s. This period became known as the «discharge of tension». However, the next stage in the development of the security system, both international and national, witnessed an increase in threats and a new range of use of military force as a means of conflict resolution, with both internal and external.

The collapse of the communist regimes has caused an outbreak of internal armed conflicts and the use of force at the international level, in particular in the territories of the former USSR, Yugoslavia, Albania, some of which have not yet disappeared or have become so-called «frozen» conflicts. Examples include the war in Bosnia and Herzegovina, the conflicts in Moldova (Transnistria), Georgia (Abkhazia and South Ossetia), Tajikistan, the Armenian-Azerbaijani confrontation (Nagorno-Karabakh), etc. And today Ukraine can be included to this list, where for more than 5 years there has been an armed conflict with the participation of the Russian Federation, which includes annexation of Crimea and hostilities in the east of Ukraine.

It should be noted that there are different theories of conflict. Thus, according to one of them, conflicts arise on the so-called «lines of division between civilizations», where there is a clash between different cultures and systems of values. In particular, characterizing this type of armed conflict, American political scientist S. Huntington notes that «fault line conflicts are communal conflicts between states or groups from different civilizations. Fault line wars are conflicts that have become violent. Such wars may occur between states, between nongovernmental groups, and between states and nongovernmental groups $\rangle^{7}$.

Against the backdrop of the analysis of the situation, theories emerged about the formation of a new "arc of instability and conflict» from the Balkan Peninsula to Afghanistan, where local and regional conflicts were resolved by military means in the form of peacekeeping operations to maintain peace or to compel peace or to cease armed violence. Such operations are mainly carried out under the mandate of international organizations, first and foremost the UN. History provides both positive and negative examples of the use of force in international relations to solve complex problems and establish peace in a particular region. So, successful is the international operation in Iraq, dubbed «Desert Storm», which restored

${ }^{7}$ Huntington S. P. The Clash of Civilizations and the Remaking of World Order. New York: Simon and Schuster, 1996. P. 252. 
Kuwait's independence captured by Iraq during the aggressive war, which had catastrophic consequences for the aggressor himself ${ }^{8}$.

The liquidation of Saddam Hussein's regime has significantly reduced the level of further aggravation of the military and political situation in the region, although it has not solved all the problems. Of course, not all peacekeeping operations are successful. So, the peacekeeping operation in Somalia was unsuccessful, where inter-tribal war actually led to the collapse of statehood. Operations in Africa, in the Great Lakes region, where fierce ethnic wars have unfolded, have proved ineffective. This is indicative of a downward trend in the role of military power, which has often been unable to resolve conflicting political problems.

A similar situation has arisen from time to time in different years. For example, in the 1970s, the US was defeated in Indochina, and the USSR was defeated in Afghanistan in the 1980s. With overwhelming military power, these states could not win and achieve their political goals in these regions. The trend continued in the 1990s: the result was the repeated defeat of the Russian army in Chechnya (Ichkeria). Another manifestation of this tendency was the emergence of a kind of deadlock in a number of local conflicts, when prolonged hostilities exhausted all parties involved and did not lead to any victory. However, the problems of international legitimation of military intervention in the modern world in the context of local conflicts of different internal and external origin, put on the agenda of international relations a number of complex and ambiguous issues. In particular, this concerns situations of mass violations of human rights by criminal authorities. The actions of the United Nations are often ineffective, especially given that there are fundamental differences in the assessment of such regimes among the five permanent members of the UN Security Council or are themselves parties to the conflict. Such situations stimulate discussions on UN reform.

In some cases, the use of force has created new problematic situations. Examples include military intervention on various grounds and with substantially different levels of international support, such as the NATO operation against the Milosevic regime, the Afghanistan war, the operation of the international coalition against Saddam Hussein in Iraq, the RussianGeorgian war of August 2008, the creation of a closed-air regime in Libya during the overthrow of the Gaddafi regime, hostilities against IS in the Middle East, military intervention in civil strife in Syria and several other events on the geopolitical map with diametrically different positions of the participating parties and those who support them.

\footnotetext{
8 Современные международные отношения. Под. ред. А. В. Торкунова. Москва: Российская политическая энциклопедия (РОССПЭН), 1999. С. 68-72.
} 
All these military and political events, regardless of their degree of completion, highlight many of the problems and contradictions that exist in the system of international relations and in international organizations at the global level, such as the UN, which are designed to regulate international conflicts. The most researched from this point of view is the war in the Balkans. One of the important conclusions of this war is, first of all, the confirmation of the need for self-restraint and coordination of efforts in military-political relations.

The involvement of nuclear powers on different sides in the war with the Milosevic regime: Russia - on the one hand, the United States, Britain and France - on the other, fortunately, did not lead to the use of nuclear potential and nuclear status. But the very fact of having weapons of mass destruction among the parties to the conflict is too dangerous and threatening, demonstrating the urgent need for self-restraint and rigid self-control.

At the same time, these events confirmed the effectiveness of coordination of actions, joint efforts of states to solve difficult situations. The NATO nations have achieved a convincing victory by fixing the Rambouillet talks. This reaffirmed the importance of joint action within a military and political structure such as NATO for the effective use of military force to achieve humanitarian goals.

However, the development of the world political process at different stages and in different regions gives much evidence of the tendency that political and economic sanctions and diplomacy may be more effective than direct military pressure and armed violence. An example is the collapse of the communist regimes in Central and Eastern Europe and the collapse of the Soviet Union, which have resulted from the excessive burden of military spending, will lose the race to ensure the proper material standard and quality of life of the population and the result of changes in ideological values.

The diminishing role of the military way of resolving conflicts within the international relations system did not mean a complete rejection of it. Power methods are used both in the traditional version and in new forms of various peacekeeping operations. However, the situation in the world at the turn of the XX-XXI centuries also showed new trends: orientation towards the use of a large arsenal of peaceful ways of resolving conflicts with emphasis on the priority of human rights, protection of its freedoms and creation of normal conditions for existence and development. This contributed to the further democratization of the entire system of international relations, the expansion of the institutional framework for cooperation and the establishment of civilizational communications, and the expansion of a secure space in international relations. 
To be true, the latest trends have given rise to certain illusions that have weakened security both internationally and in terms of national security in individual countries. In particular, it concerns the situation in Ukraine related to the annexation of Crimea and the beginning of the Russian aggression in the East of Ukraine since 2014. This has a number of negative effects, which does not contribute to strengthening security within the international relations system. The world community has proven unable to prevent a range of forms of violence, including hybrid wars, the overall crime rate and the use of repressive methods that threaten human security.

This puts states before choosing a model for ensuring their own security. There are two alternatives: to integrate into a new model of international relations that eliminates the very sources of potential conflict; or stay in an old, confrontational model where military power and the right of a stronger army play a major role. The events of recent years demonstrate the devastating fallacy of implementing the second approach, in particular, the present-day Russian Federation, forcing Ukraine to seek opportunities for a new international order and security that is capable of providing real security guarantees and maintaining stability in international relations, taking into account national interests of all parties. Ukraine's strategic intentions to join NATO are clear evidence of such a search. And such a course was confirmed by the decision of the Verkhovna Rada of Ukraine of February 7, 2019 on amendments to the Constitution aimed at consolidating the strategy of achieving EU and NATO membership?

Along the way, new tasks are emerging or new content is being provided to existing security and support tools in an extremely complex modern environment, when conflicts intersect in different areas. The ambiguity of the conditions of activity accordingly requires similar ways and means of talking the emerging issues.

\section{Hybrid nature of modern conflicts}

Confrontation in today's environment focuses on new priorities, demanding a comprehensive approach to security. This is especially true of the information sphere, which has become a field of active struggle in the face of hybrid forms of confrontation and conflict.

The events of recent years have convincingly demonstrated that domination in the information field enables successful achievement of foreign and domestic policy goals. Obtaining information advantage is seen

\footnotetext{
${ }^{9}$ Про внесення змін до Конституції України (щодо стратегічного курсу держави на набуття повноправного членства України в Європейському Союзі та в Організації Північноатлантичного договору): Закон України від 07.02.2019 р. № 2680-VIII. Офіційний сайт Верховної Ради України. URL: https://zakon.rada.gov.ua/go/2680-VIII.
} 
as an effective and promising tool to achieve political goals in situations where the use of force is impossible or impractical. Information warfare moves from the military and technological sphere to the formation of ideological stereotypes through the methods of political manipulation and linguistic programming. In modern discourse, the latest concepts are widely used: fakes, trolls, bots, etc.

Until recently, the United States led in the propaganda support of political goals, in the last decade the information and expansionist activities of the Russian Federation have intensified, which is large-scale, costly and rather aggressive. So, the US and a number of European countries have been forced to investigate Russia's interference with information technology into electoral processes, and Ukraine has felt the devastating impact of such activities, especially since 2004.

The main objectives of information excellence are to target the adversary with prepared or false information or misinformation, as well as to limit the ability to obtain reliable information about real plans and intentions. An important part of the information war is the creation of favorable public opinion in the country around the operation. The range of tools used varies from traditional propaganda and agitation to the use of the latest technical capabilities, including social networks, to create the desired virtual reality, manipulation of consciousness. Modern researchers, in particular, G. Pocheptsov, A. Shevtsov, and other refer the changes in consciousness to global threats in the process of constructing the future, because such changes are capable of fulfilling both positive and negative functions. So G. Pocheptsov emphasizes that modern «global projects are aimed either at a significant correlation of mass consciousness, or to its complete change» ${ }^{10}$. A. Shevtsov, warning of the possibility of such threats, argues that «scenarios of the future should plan to preserve civilization» ${ }^{11}$.

The combination of technological innovations with methods of information-psychological action allowed developing the concept of «effects based operations». The meaning of such operations is the ability to abandon the physical destruction of the enemy, and to change his behavior, psychologically adjust him to the possibility of gaining capitulation and giving up armed resistance. The RF applies the same nowadays. New tools do not exclude the use of force, but focus on tools of psychological pressure.

${ }^{10}$ Почепцов Г. Глобальні проекти: конструювання майбутнього. Київ: Український центр політичного менеджменту, 2009. С. 6.

11 Шевцов А. І. Майбутнє людства необхідно спланувати: глобальні загрози і довгострокова стратегія розвитку України. Стратегічні пріоритети. 2007. № 1(2). C. 188 
Diplomacy, economic and political influences are also used to change attitudes and behavior. The use of such soft power becomes more effective than direct military pressure in today's international relations.

It should be noted that such actions are not a completely new invention of humanity. Such a hybrid approach, focused on the behavioral motivations of the enemy, suggested in his time Karl von Clausewitz, emphasizing the importance of psychological aspects of war. But the use of innovative techniques and technologies gives such actions scale and effectiveness.

Such effects based operations have a number of advantages: integrated planning provides for the integration of military and non-military aspects, effectively selects goals and prioritizes them, identifies enemy weaknesses; does not destroy, but uses the infrastructure of the enemy; all sources of power of their own state are used optimally - political, economic, military and diplomatic; encourages the interaction of command with other actors in the campaign, thereby reducing the likelihood of errors and inconsistencies; innovative forms of action, such as networking, are introduced.

The information component of the concept of effects based operations has been used quite successfully in the Second Iraqi War. During this campaign, the psychological war against Iraq was fought through 50 million leaflets and hundreds of hours of radio and television broadcasting. At the same time strategies of suppression of communication systems of the enemy were applied, misinformation was used. All this was complemented by the Allied military operations in the framework of air and ground operations, during which the Iraqi military and political leaders and terrorist group leaders were destroyed. It accelerated achievement of goals even in difficult natural conditions and in a situation of specific guerrilla struggle.

From a military and technological point of view, the Second Iraqi War achieved short-term goals in the shortest possible time and with minimal cost. However, there were no long-term political goals, especially after the formation of IS units in Iraq: there is no sustainable peace and democratic regime in Iraq. The Second Iraq War was in fact the first campaign that was fully planned based on the concept of result-oriented operations. But it has shown that even cutting-edge technology alone does not guarantee the achievement of political goals, especially strategic ones, not just temporary ones.

Realizing this, a number of result-oriented operations theorists began to turn to Clausewitz's ideas, to draw on Lenin's understanding of war as a natural form of politics. Similar views dominate in Putin administration, justifying the war, seeking to portray it in the eyes of Russian and world public opinion as the usual means of regulating international relations. However, not taking into account that the same Karl von Clausewitz 
regarded the war solely as an extreme, marginal and in this sense exclusive phase of the political struggle.

This is the approach that Russian politicians and authorities have demonstrated in their relations with Ukraine since March 2014. The information war of previous years is complemented by military presence and efforts to present events as a natural result of Ukraine's internal conflicts and justified actions by Russia. From the logic of this approach, the idea of the possibility of changing the world order will follow. Speech by Prime Minister of the Russian Federation D. Medvedev at the Munich Security Conference in February 2016 fits in with a similar understanding of modern information operations. In fact, he declared such a war with the West in the form of a new variant of the modern Cold War.

Such statements force countries to create mechanisms to counteract information interventions that can weaken security. Moreover, they find evidence of the Russian cyber-intervention in electoral processes in the United States, France, Germany, the Netherlands, which are being investigated and regarded as real threats to the national security of countries. Similar questions have arisen in the UK about preparing public opinion for a decision to leave the EU. Instead, there is a need for counter-measures similar to the creation of a US NSA Task Force on Counteracting Russian Threats in Cyberspace, announced at the 2018 Annual Aspen Security Forum.

For Ukraine, the information war, cyberattacks on the part of the Russian Federation has long been a reality that needs active counteraction. The importance of the formation and continuous improvement of an effective state-legal mechanism in the field of information security has been emphasized by scientists for a considerable period. ${ }^{12}$

However, adequate policy response has not taken place, despite the fact that information wars have become an integral part of modern hybrid forms of war. They create no less tension in international relations than traditional armed confrontation, the level of which has declined somewhat since the second half of the twentieth century.

Humanity in the first half of the twentieth century failed to create a credible security system: two world wars and bloody revolutions claimed the lives of more than 100 million people and disabled more than 40 million. World War II alone, in monetary terms, cost more than $\$ 662$ billion. All of this has led to a rethinking of ways and methods of conflict resolution with the use of weapons, which have become increasingly devastating.

12 Кормич Б. А. Організаційно-правові засади політики інформаційної безпеки України. Одеса: Юридична література, 2003. 472 с. 
The peculiarity of the second half of XX century and the beginning of the 21 st century is that the global community has been able to prevent the major threat to international security, and at the same time to the national security of individual countries - the threat of unleashing a new, this time, fusion war capable of destroying all life on Earth. Bans and restrictions have been introduced on a number of weapons of mass destruction, such as nuclear, chemical, and bacteriological. But even stockpiling, as well as the destruction of such weapons, involves not only enormous financial costs but also threats to the security of the public and the environment.

In addition, prohibited weapons, such as vacuum bombs, anti-personnel landmines, or even chemical weapons, are occasionally used in regional and local conflicts, including military ones. For example, similar questions have arisen regarding Syria on April 5, 2017, when more than 70 people were killed in the sarin gas bombardment, 27 of which were women and children, and more than 540 were found in hospitals with long-banned chemical weapons poisoning. These issues were discussed at the UN Security Council, though without decision-making. The answer was an American rocket attack on the Syrian Air Force base, from which aircraft with illicit chemical weapons lifted. Therefore, it can be stated that the world community of the second half of XX - early XXI century made a major step forward in the direction of democracy, the protection of human rights and fundamental freedoms, and the improvement of economic and social conditions of people. But it has not been able to prevent fully violence in its various manifestations, that is, to ensure security of development.

In this respect, security is also a common crime in the world. Since the 1980 s, crime has increased by $5 \%$ annually in the world and has become an organized feature ${ }^{13}$. The initiators and perpetrators of crime are organized groups that have the latest weapon systems, communications, eavesdroppers, etc. Such criminal groups create skilled staffs, operational services, have predesigned crime plans. Such «criminal communities» are distinguished by a high level of organization, detailed preparation of criminal activities, broad financial resources, a hierarchy of management and discipline. The recent trend is the rapid growth of transnational criminal organizations with the participation of citizens of several countries, criminal activity in a number of countries, the organization of crimes that violate international obligations and international law. Such transnational crime groups are quickly adapting to new circumstances and often act as an additional provoking factor for conflicts, including by escalating international tension, deteriorating international cooperation, provoking local, regional, and international conflicts.

13 Современные международные отношения. Под. ред. А. В. Торкунова. Москва: Российская политическая энциклопедия (РОССПЭН), 1999. С. 111-113. 
The most dangerous form of crime in the world today is international terrorism. The goals of terrorism are varied: changes in political structure, leadership or course of the country; imposing sectarian, radical nationalist, fundamentalist and other beliefs on people; loosening the state of stability in society, intimidation of the population, provocation of hostilities, release of participants in terrorist acts, etc. The arsenal of terrorist methods and means is also broad: assassinations of political leaders, hostage-taking, undermining of important civic objects and institutions; recruitment, financing, training of mercenaries and their use in military and terrorist acts; capture of airplanes, television and radio centers, infrastructure; illegal television and radio and more. Back in the early 90's of the twentieth century. around 500 terrorist organizations and groups of various extremist backgrounds have been active in the world. In the course of 10 years, they have committed more than 7,000 terrorist crimes that have killed more than 11,000 people ${ }^{14}$.

But their existence was seen as part of the political landscape of only a few troubled countries and regions. Only after the September 11, 2001, terrorist attacks in the United States were considered a major security threat to all. The world has realized the real threat to security from terrorist networks that have spread to different countries, even the most stable ones. Today, a major threat to security is, in particular, the activities of a terrorist organization such as the Islamic State, which has already surpassed the scale of al-Qa'ida's crimes.

A serious threat to the international community is the crime associated with drug trafficking. The number of such crimes in the world is growing at such a rapid rate that this process is being compared to an epidemic. In the first five years of the 2000s, the number of drug-related crimes in the world increased in 5 times. A characteristic feature of the modern drug business is going beyond national borders, organization of illegal international traffic, covering almost all countries of the World. Powerful groups have been formed that have a wide network of not only trade but also manufacturing enterprises, their own laboratories, specially trained staff. The international narcotics business is making a huge fortune for its owners. For example, the total annual income of the American Mafia from drug smuggling is more than $\$ 1$ billion, which exceeds the national budgets of several countries. Concentrating money in the hands of drug dealers creates a problem of money laundering, which causes new crimes. The consequence is the harm to the health of a large number of people, reducing their social activity, deterioration of the gene pool of the population. Possession of large sums of money allows to exert pressure on representatives of the authorities, law

14 Шерпаев В. И. Военная политика современной России. Екатеринбург: Изд-во Уральского университета, 2007. С. 127. 
enforcement agencies, mass media, which loosens the stability of society, undermines its security.

Security threats are posed by crimes that infringe upon the personal rights of citizens: exploitation of child labor, trafficking in human beings, the spread of pornography, the forcible abduction of persons for exploitation or ransom. This kind of crime takes on new forms, often hidden and therefore difficult to recognize. In the context of conflicts in different regions, such activity is significantly intensified, which is also felt by Ukrainian society today. The military conflict in the east of Ukraine, supported by the actions of the Russian Federation, stimulates similar criminal forms that create new security threats for individuals and society as a whole.

A new and dangerous type of crime is illegal high-tech operations involving the use of a network of computers, telecommunications equipment, and other types of high-tech technology. These are numerous variants of cybercrime, illegal cloning experiments with the threat of gene pool, and information and psychological manipulation of human consciousness, and more.

The creation and activities of private armies, such as the private military campaign Wagner in the Russian Federation, which are used to obscure the participation of regular military units in other countries, can be included in the category of criminal acts today. This structure was used by the Russian Federation in eastern Ukraine, Syria, to deny its direct involvement in military operations. Such a phenomenon, in our opinion, effectively erodes Weber's understanding that any territorial political organization «will be called 'state' insofar its administrative staff successfully upholds the claim to the monopoly of the legitimate use of physical force in the enforcement its order» ${ }^{15}$, which has been extended by F. Fukuyama thesis that state's essence is nothing more than power of enforcement and possibility to send somebody in uniform and with weapons ${ }^{16}$. Because, the failure to grant such monopoly is not merely issue of a weak state under attack, but to the great extend it is also the issue of the state inspiring such «private» military campaigns, so far the latter can not grant the same level of control and responsibility for its «private» armed proxies as it can grant in case of its military forces. After all, it testifies to the inability of some subjects of world politics to solve civilly complex political problems in the present conditions and, in turn, could lead to the transformation of entire states into terrorists, if such a tendency dominates and the uncontrolled field of aggression dominates. And it is a great threat to the whole system of international relations.

\footnotetext{
${ }^{15}$ Weber M. From Max Weber: Essays in sociology. London: Routledge, 1991. P. 78.

${ }^{16}$ Fukuyama F. State Building: Governance and World Order in the Twenty-First Century. London: Profile Books Ltd, 2004. P. 6.
} 
Thus, the world community at the beginning of the XXI century faced new security challenges and threats, both nationally and regionally or globally. Many of the emerging threatening occurrence and phenomena are directly related to the effect of globalization. The point of view is widely held that the emergence of international threats is the result of an archaic and asymmetric response to globalization by world outsiders unable to fit into the new rules of the game. In many interpretations, the situation is described as a clash of global political and socio-economic processes and new globalizing institutions with reactionary traditionalist ideologies that have «mutated» and their organizational practices. Threats represent «all Western» denial and / or the quintessence of primitive anti-globalization. But such interpretations are too limited and do not take into account the positive results of globalization, focusing only on the negative aspects of the process. They categorically oppose globalization and glokalization and are unable to take into account the positive of each of these processes.

In some cases, the explanation, for example, of international terrorism is based on an analysis of the specific role of authoritarian regimes in particular regions, in particular, in the Middle and Middle East. According to similar interpretations, the victory of national patriotic forces is possible only if any support to the non-patriotic ruling regimes ceases, and terror acts as a means of achieving this goal. However, a significant number of regimes today are hybrid in nature, not being a purely authoritarian variant, which creates certain problems in assessing their behavior and in their attitude to the environment.

Today, in order to overcome threats to national security, as well as international security, a system capable of integrating the resources of both individual states and the international community as a whole must function effectively. It should be based on the principles and norms of international law and national legal systems and combine international and national institutional capacities. The public sector should also be involved in the public sector in the form of public institutions of different profiles and levels. Only such an integrated approach will guarantee success in creating the conditions for the secure existence of man, the state, society, and in return, the global community as a whole and democratic progress.

The most comprehensive approach to security issues was announced by Ukrainian researchers such as V. Gorbulin, O. Lytvynenko, O. Dzoban, G. Kostenko, V. Lipkan, and many other national security experts who analyzed in detail the theory and practice of implementing security strategies ${ }^{17}$.

17 Горбулін В. П., Літвіненко О. В.Національна безпека: український вимір. Київ: Інтертехнологія, 2008. 104 с.; Національна безпека України: концептуальні засади та світоглядний сенс. Ред. О. Дзьобань. Харків: Майдан, 2007. 284 с.; Теоретичні основи та елементи національної безпеки України. Ред. В. Ліпкана. Київ: Текст, 2003. 600 с. 
Despite such complexity, the main focus is on military security, preserving the integrity and independence of the state, protecting its national interests. The new military doctrine of Ukraine introduced by the Presidential Decree of September 24, $2015^{18}$ and the new Law on National Security, adopted by the Verkhovna Rada of Ukraine on June 21, $2018^{19}$, which define a new military doctrine of Ukraine, confirm this approach to understanding the categories of «national security» and «international security» content, forms, directions and methods of security protection in modern conditions.

The corresponding tendencies of security understanding were also enshrined in the amendments to the Constitution approved by the Verkhovna Rada of Ukraine, which should become a guaranteed security strategy of development of society and state and integration of Ukraine into the world security processes on the basis of democratic transformations. And it is important to follow the chosen course despite the changes in the state leadership as a result of regular election campaigns in the country presidential or parliamentary. The consistency of foreign and defense policy is the basis for the security and success of democratic reforms.

In spite of the nonlinear nature of the development and the multiplicity of such processes, the analysis of the factors of influence on them gives effective tools for the real creation of safe conditions for the existence of man, society, state and the world community in the present conditions and advancement of the world political process in the direction of civilizational progress. Institutional, regulatory and procedural transformations, both nationally and internationally, must be subject to this goal. This is the path Ukraine is taking, strengthening its own security, contributing to the international security system and gradual integration into the European security area.

Complex problems of interstate relations and world politics were discussed at the 55th Munich Security Conference, held on February 15-17, 2019 with the participation of heads of many states, ministers, representatives of the world political elite. The agenda included issues of world security, competition of major powers, the actual withdrawal of the Russian Federation and the US response to the treaty on medium - and lowrange missiles, Russian aggression in Ukraine, environmental security, challenges of the North Stream 2, and several other important security issues. The success or failure of dialogue between states largely depends on determining the strategies and prospects for the development of the global

${ }^{18}$ Про рішення Ради національної безпеки і оборони України від 2 вересня 2015 року «Про нову редакцію Воєнної доктрини України»: Указ Президента України № 555/2015 від 24.09.2015. Офіиійний вісник Президента Украӥни. 2015. № 22. С. 19. Ст. 1291.

19 Про національну безпеку України: Закон України від 21 червня 2018 p. № 2469-VIII. Відомості Верховної Ради України. 2018. № 31. Ст. 241. 
political process. Because every such step is able to both strengthen security and produce new security threats. Therefore, common sense should be encouraged to preserve the life and civilization progress of mankind.

\section{CONCLUSIONS}

Researchers interpret the content of security in ambiguous manners. Supporters of a «broad» interpretation of the subject field of security characterize the expansion of the security space in four dimensions. The first one concerns the extension of security «down from states to individuals». The second embodies the vision of «upward from states to the biosphere.» The third concerns the horizontal aspect - military, political, economic, social, environmental, human security, etc. The fourth dimension refers to political responsibility for security, which is «scattered» in all directions: from states upwards to international institutions, and downwards to regional and local authorities, non-governmental organizations, public opinion, the press, etc.

Expanding the content of security provides the ability to withstand the current challenges and threats, to create a secure environment that guarantees the development and deepening of democracy.

The diverse nature of the threats determines a wide range of security activities: military-defense, information, environmental, economic, financial, socio-demographic, energy, ethno-national, religious. Thus, it can be concluded that expanding the content of security in modern conditions and the hybrid nature of the processes of formation of security threats require the definition of indicators, incentives, etc. to justify the prospects for the development of the global political process and to form on this basis a safe environment for successful implementation of progressive changes in different spheres of life. Creating new models of national and international security that can meet the current threats and challenges is an important factor in successfully solving the complex challenges of democratic transit and the further development of democracy. The main thing in this case is the introduction of promising models and real programs for the safe functioning of humanity into practice. The dynamic era of democratic change contributes to these challenges. Through reforms, Ukraine can make the most of the opportunities provided, take a prominent place in the implementation of this progressive trend, pursuing a course of strengthening national and international security and creating favorable conditions for sustainable development.

\section{SUMMARY}

At present, the content of the security concept has expanded significantly, covering different spheres and levels of life. Security issues have become key in functioning of many international and national 
institutions. The security system as a functional reflects the interaction of interests and threats, and the security system as an organizational and institutional system creates mechanisms for protection and prevention of threats. The specificity of security in the context of the development of democracy, above all, needs to improve the legal framework both in the aspect of international law and in the framework of national legislation. Regulatory and procedural features are determined by specific security regimes. The hybrid nature of modern processes dictates the need for a comprehensive approach to the design and regulation of the functioning of a complex security system and models of its provision. The specific experience of countries indicates the need to increase the effectiveness of the security system for the implementation of democratic reforms.

\section{REFERENCES}

1. Fukuyama F. State Building: Governance and World Order in the Twenty-First Century. London: Profile Books Ltd, 2004. 256 p.

2. Huntington S. P. The Clash of Civilizations and the Remaking of World Order. New York: Simon and Schuster, 1996. 367 p.

3. Machiavelli N. The prince. Translated with an introduction by H.C. Mansfield. 2nd ed. Chicago: The University of Chicago Press, 1998. $184 \mathrm{p}$.

4. Toynbee A. J., Ikeda D. The Toynbee - Ikeda Dialogue: Man Himself Must Choose. Tokyo: Kadansha International, 1976. 348 p.

5. Weber M. From Max Weber: Essays in sociology. London: Routledge, $1991.514 \mathrm{p}$.

6. Wright Q. A Study of War. In 2 vols. Chicago: University of Chicago Press, 1942. Vol. 2. 1552 p.

7. Горбулін В. П., Літвіненко О. В. Національна безпека: український вимір. Київ: Інтертехнологія, 2008. 104 с.

8. Клаузевиц К. О войне. В 2 т. Москва: АСТ. Санкт-Петербург: Terra Fantastica, 2002. T. 1.558 c.; T. 2.574 c.

9. Кормич Б. А. Організаційно-правові засади політики інформаційної безпеки України. Одеса: Юридична література, 2003. $472 \mathrm{c}$.

10. Національна безпека України: концептуальні засади та світоглядний сенс. Ред. О. Дзьобань. Харків: Майдан, 2007. 284 с.

11. Почепцов Г. Глобальні проекти: конструювання майбутнього. Київ: Український центр політичного менеджменту, 2009. 211 с.

12. Про введення воєнного стану в Україні: Указ Президента України від 26 листопада 2018 р. № 393/2018 (Указ затверджено Законом № 2630-VIII від 26.11.2018 із застереженням). Голос Украӥни. 28.11.2018. № 226.

13. Про внесення змін до Конституції України (щодо стратегічного курсу держави на набуття повноправного членства 
України в Свропейському Союзі та в Організації Північноатлантичного договору): Закон України від 07.02.2019 р. № 2680-VIII. Офіщійний сайт Верховної Ради України. URL: https://zakon.rada.gov.ua/go/2680VIII.

14. Про національну безпеку України: Закон України від 21 червня 2018 р. № 2469-VIII. Відомості Верховної Ради Украӥни. 2018. № 31. Ст. 241.

15. Про рішення Ради національної безпеки і оборони України від 2 вересня 2015 року «Про нову редакцію Воєнної доктрини України»: Указ Президента України № 555/2015 від 24.09.2015. Офіиійний вісник Президента Украӥни. 2015. № 22. С. 19. Ст. 1291.

16. Современные международные отношения. Под. ред. А. В. Торкунова. Москва: Российская политическая энциклопедия (РОССПЭН), 1999. 584 с.

17. Теоретичні основи та елементи національної безпеки України. Ред. В. Ліпкана. Київ: Текст, 2003. 600 с.

18. Шевцов А. I. Майбутне людства необхідно спланувати: глобальні загрози і довгострокова стратегія розвитку України. Стратегічні пріоритети. 2007. № 1(2). С. 187-193.

19. Шерпаев В. И. Военная политика современной России. Екатеринбург: Изд-во Уральского университета, 2007. 171 с.

\section{Information about the author:}

Kormych A. I.,

$\mathrm{PhD}$ in History, Associate Professor, Associate Professor at the Department of General Jurisprudence of the National University «Odessa Law Academy» 2, Akademichna str., Odessa, 65009, Ukraine 
DOI https://doi.org/10.36059/978-966-397-158-2/41-66

\section{INFORMAL DESTRUCTIVE POLICY PRACTICES AS A FACTOR OF INFLUENCE ON DEMOCRATIC POLITICAL TRANSIT}

\section{Krasnopolska T. M.}

\section{INTRODUCTION}

Democratic political transit is a condition for constructive socio-political changes in society and the prevention of backward movement in which destructive political institutions and practices are involved.

Constructive socio-political changes imply the development of the political system of society, and both state institutions and mechanisms of their functioning, as well as elements of civil society. An important role in these processes is played by the establishment of interaction between the state and civil society, since only as a result of cooperation, that is, the introduction of the social partnership model of these elements of the system, positive changes are possible.

In our country, at the present stage of its development, both groups of political transit conditions are present.

The set of constructive socio-political changes necessary for political transit through democratization can be combined with the definition of «parity democracy». Using this model of democracy will be the key to successful democratic transit, requiring the improvement or creation of new formal institutions and mechanisms for their interaction at the state and nonstate levels, and the inclusion of constructive positive informal practices in the process. An effective mechanism for the introduction of parity democracy is an orderly system of international, regional and national structures of state and civic nature, whose activities are aimed at affirming the principle of parity in different spheres of social life and guaranteeing the implementation of the strategies and policies developed by them ${ }^{1}$.

However, among the factors that hamper the pace of democratic transit and threaten to return to an undemocratic political regime, the manifestation

\footnotetext{
${ }^{1}$ Кормич Л. І., Краснопольська Т. М. Основні напрями стратегії впровадження моделі паритетної демократії в сучасній Україні. Актуальні проблеми політики. 2018. Вип. 62. C. 16 .
} 
of destructive informal political institutions and practices plays a leading role. It is their analysis that should be discussed in detail.

\section{Informal destructive political practices: place and role in the political process}

In recent years, the informal component of the institutional process has intensified, as evidenced by numerous social, political and economic indicators. The destructive upheavals of recent decades in a number of countries are caused by a surge of informal political practices of a radical nature that tends to be political violence and is expressed in the practice of separatism, extremism, terrorism.

The study of informal political institutions and practices is the latest trend in political science, presented in the works of D. S. North (laid the foundation of neo-institutional theory), S. Levitsky and G. Helmke, V. Merkel and A. Croissant (identified the features of informal institutions in defective democracies), C. Patrushev (exploring the possibilities of neoinstitutionalism for political process analysis), etc.

Among the domestic researchers worth mentioning are the developments of M. Karmazina, I. Kushnaryov (proving the interdependence of informal institutionalization and political regime, the level of civil society, the steadiness of democratic traditions, etc.), Yu. Matsievsky (examines the role of corruption, clientelism, nepotism, favoritism, patronage in hybrid regimes), A. Mogylova (analyzes methodological problems of development of modern institutional theory), V. Popoglo (conceptualizes informal destructive institutions of politics, forms of their manifestation and defines mechanisms of counteraction to them), O. Stoyko (sees reasons for the development of destructive informal institutions in the weakness of formal and constructive informal ones), M. Chabannoy (proving the role of informal institutions in political regimes with a low level of democracy), T. Shevchenko (exploring informal institutions through the analysis of essential characteristics and features of informal politics), etc.

Some authors devoted their research to the analysis of the essence of certain forms of destructive informal institutions. Thus, corruption was studied by D. Botalov, K. Davydenko, G. Kohan, T. Mirzoev, I. Revak, favoritism - I. Didenko, S. Paramonova, kronism - O. Oliynyk, clan O. Babkin, M. Mikhalchenko, patron-clientelism - I. Kovalska-Pavelko, O. Polishchuk, Y. Teleshun, V. Shevchuk, nepotism - Y. Nisnevych and others. 
The current political process is a multidimensional phenomenon, involving a large number of actors who use a diverse arsenal of political practices and institutions to achieve their goals.

Political practices are a set of rules, traditions and norms of behavior adopted in a given society. According to D. Budko, political practices can be defined as the reproduction of laws, stereotypes, rules that determine the presence of a political institute, and its interaction with other institutions ${ }^{2}$.

The whole variety of political practices can be represented by their division into formal and informal ones. If the rules and regulations established at the state level are formal practices, then the definition of informal practices is not as straightforward. This is explained by the complexity of the interpretation of the term «informal» itself, as well as its interrelation with the formal elements of political institutions. The latter allows us to include traditions, moral norms, etc. in informal political practices.

More often than not, informal political practices mean the constantly reproduced stereotypical rules of interaction of policy-makers established and supported by socio-cultural regulators: values, political orientations, attitudes, rather than formal legal norms ${ }^{3}$. They aim at gaining public authority and / or increasing the resources of the policymaker. They compensate for the inefficiency of formal institutions and practices of society, integrate a coherent communicative space.

Informal practices are most characteristic of non-Western societies. They become a much-needed political tool in the stage of institutional transformation, during the crisis and the destruction of old institutions ${ }^{4}$. The presence of informal political practices in the society indicates that there are some contradictions, and the subjects of the political process cannot for objective reasons or do not want to go democratically.

Informal political practices and institutions can be both constructive and destructive. However, the classification proposed by G. Helmke and S. Levitsky, which involves four types of informal institutions on the basis of two criteria, is more informative: the degree of difference between the results of the activities of certain interconnected formal and informal

\footnotetext{
2 Будко Д. А. Политические практики взаимодействия органов региональной власти в современной России: дисс... канд. полит. н.: 23.00.02. Санкт-Петербург, 2014. С. 9. URL: https://disser.spbu.ru/disser2/disser/Dissertazija_BudkoDA.pdf.

${ }^{3}$ Подхомутникова М. В. Неформальные политические практики в современной России: субъекты институиионализации: автореф. дисс. на соискание уч. степени к-та полит. н.: 23.00.02. Краснодар, 2010. 27 c. URL: http://cheloveknauka.com/v/335868/a?\#?page=27.

4 Мамчуева Ф.Ю. Формальные и неформальные политические практики современного политического процесса. Историческая и сочиально-образовательная мисль. 2013. № 5(21). С. 153.
} 
institutions (convergent - essentially the same, or divergent) and the effectiveness of the relevant formal institutes (the degree of adherence to paper-based rules and procedures $)^{5}$.

Researchers identify the following types of informal institutions and related policy practices:

- additional - co-exist with and cooperate with formal institutions to make policy outcomes more effective; a set of rules, routines and procedures that facilitate decision-making and coordination of bureaucratic activity, uphold legal norms (so researchers relate the effectiveness of the US Constitution to a range of informal rules, common abeyances and expectations common to citizens);

- adaptive - inherently contrary to the spirit, but not to the «letter» of the written law (informal consultations on harmonization of legislative actions, group agreements, etc.);

- substitutes - exist in a poorly institutionalized environment of weak state power, but contribute to the achievement of policy results, which formal institutions have failed to implement («gentlemen's agreements», public spouses of self-defense, informal courts, etc.);

- competing - arise in conditions of systematic non-compliance with ineffective norms of formal institutions and structure the behavior of political actors in such a way that they are compelled to adhere to the established informal rules, in fact facing the threat of punishment for following formal laws (corruption, clientelinetics) ${ }^{6}$.

German researchers V. Merkel and A. Croissant call «damage» to liberal-constitutional, legitimate and legally established norms by informal institutions and political practices as a key characteristic of post-Soviet regimes. According to these authors, this «deformation» of political procedures and decision-making rules arises, first of all, from a combination of two factors that have roots in the pre-democratic past: the authoritarian inheritance of informal practices; the accumulation of the economic and political problems of the post-authoritarian system that have been transferred from the authoritarian phase. These factors create favorable conditions for

\footnotetext{
${ }^{5}$ Helmke G., Levitsky S. Informal Institutions and Comparative Politics: A Research Agenda. Perspectives on Politics. 2004. Vol. 2. Issue 04. P. 728 . URL: https://wcfia.harvard.edu/files/wcfia/files/883_informal-institutions.pdf.

${ }^{6}$ Helmke G., Levitsky S. Informal Institutions and Comparative Politics: A Research Agenda. Perspectives on Politics. 2004. Vol. 2. Issue 04. P. 728-730. URL: https://wcfia.harvard.edu/files/wcfia/files/883_informal-institutions.pdf. 
the illiberal transformation of political institutions, which is carried out informally and leads to the advantage of informal practices ${ }^{7}$.

Informal institutions are present in various spheres of public life - from domestic (exchange of handshakes, rules of communication) to economic (shadow markets). H. Helmke and S. Levitsky write: «the term «informal institute» is used to refer to an incredibly wide range of phenomena, including personal relationships, clientelism, corruption, clans and mafias, civil society, traditional culture and various legislative, judicial and bureaucratic norms» ${ }^{8}$.

This list can be supplemented by the proposed H.-J. Laut forms: croneyism, nepotism, clientelist parties, autocratic clicks. He refers the use of the threat of putsch or military force, practices of civil disobedience, etc. to particular types of informal institutions ${ }^{9}$.

The most well-known and common form of informal destructive political practices that hinders democratization is corruption. According to the National Institute for Strategic Studies, in the post-Soviet space in recent years, the so-called «full corruption cycle», which can be reflected in the following scheme, has become a prominent place in political corruption ${ }^{10}$ :

$\mathrm{B}-\Gamma-\mathrm{B} 1>_{\mathrm{B}}-\Gamma 1>_{\Gamma}$,

where $\mathrm{B}$ and $\mathrm{B}-$ power, $\Gamma$ and $\Gamma-$ money, $\mathrm{B} 1-$ a new, increased amount of power, $\Gamma 1$ - the amount of corruption accumulated as a result of the corrupt use of power levers. It is in this cycle that such forms of political corruption as corruption lobbying, corruption favoritism, corruption protectionism, secret financing of dubious political projects in terms of public needs are widely used; contributions to the correction of election campaigns in a customer-friendly direction, with subsequent repayment of government positions, etc.

R. Karklins highlights the following types of political corruption prevalent in post-communist countries:

1) corruption at lower levels of government (bribery, deliberate manipulation of regulatory standards, use of administrative checks to solicit);

\footnotetext{
${ }^{7}$ Меркель В., Круассан А. Формальные и неформальные институты в дефектных демократиях. Полис. 2002. № 2. С. 20.

${ }^{8}$ Helmke G., Levitsky S. Informal Institutions and Comparative Politics: A Research Agenda. Perspectives on Politics. 2004. Vol. 2. Issue 04. P. 727. URL: https://wcfia.harvard.edu/files/wcfia/files/883_informal-institutions.pdf.

${ }^{9}$ Lauth H.-.J. Informal Institutions and Democracy. Democratization. 2000. Vol. 7. № 4. P. 27-43.

${ }^{10}$ Циганов В. «Загроза політичної корупції у демократичних політичних режимах». Аналітична записка. Національний інститут стратегічних досліджень. URL: http://old2.niss.gov.ua/articles/882/.
} 
2) withdrawal of assets for selfish purposes (use of state-owned assets for personal purposes, expenditures in the course of ineffective implementation of state programs, illegal profit obtained in the course of non-transparent privatization agreements with state assets; malpractice in the field of public procurement, nepotism, clientelism when appointing candidates);

3) «seizure of the state» by corrupt networks, which means using political institutions as a tool of business or openly criminal purposes. This type includes deliberate methods of reducing political competition, manipulation of electoral processes (including by creating «black box offices» of election campaigns, black PR-technologies), corruption of the legal sphere, abuse of powers of supervisory or investigative bodies on a large scale, use of compromise as a tool of political struggle, corruption of the media) ${ }^{11}$.

It should be noted that the phenomenon of corruption has existed since ancient times, as evidenced by the etymology of the word «corruption». Popular in domestic science is the version according to which «corruption» comes from the Latin «corruptio», which meant «corruption, bribery» ${ }^{12}$.

There is another point of view, in particular, the Russian researcher G. Mishin believes that: «The Latin term corruptio comes from the two root words «cor» (heart, soul, spirit, mind) and «ruptum» (to spoil, destroy, corrupt). Therefore, the essence of corruption is not in bribery, corruptibility of public and other employees, but in violation of unity (disintegration, decay) of a particular object, including public authorities ${ }^{13}$.

The first approach involves existing forms of corruption that are directly related to bribery of officials.

Second, it gives a broader interpretation of the concept and identifies two forms of corruption: «hard» (overt) and «soft» (veiled).

Thus, along with such traditional forms of corruption as malpractice and bribery and undue gain, such manifestations as: the involvement of officials and civil servants in commercial activities for personal or corporate profit, the use of official position for the purpose of so-called «transfer» of public funds for further transfer to cash and theft in banks, the provision of benefits to «their people» using public resources, use of official position to influence

${ }^{11}$ Karklins R. Typology of Post-Communist Corruption. Problems of Post-Communism. 2002. Vol. 49. № 4. P. 24. URL: http://pdc.ceu.hu/archive/00001528/01/03Karklins\%5 B1\%5D.pdf.

12 Суханов В. А. Коррупция в органах государственной власти как глобальная проблема. Вестник МГИМО. 2013. № 4(31). С. 213.

13 Мишин Г. К. О теоретической разработке проблемы коррупции. Коррупция: политические, экономические, организачионные $u$ правовые проблемы. Ред. В. В. Лунеева. Москва: Юристъ, 2001. С 264. 
the media, for personal and collective gain; the use by civil servants of fake persons and relatives in commercial structures for the purpose of personal enrichment; use of official position for distortion, failure to provide or delay deadlines for issuing information, lobbying for decisions on the adoption of normative acts in narrow group interests; providing state financial and material resources to election funds of certain applicants ${ }^{14}$.

All of the above-mentioned acts of corruption are in one way or another related to bribery of officials. In this regard, they refer to so-called «cruel» or explicit corruption. However, not only manifest corruption is widespread in political practice, but also some which, in the opinion of some authors, refer to «mild» corruption. The latter include clan and tribalism, favoritism and nepotism, clientelism and patronage, lobbying, localism and other informal practices.

Let us analyze the above forms of informal destructive political practices. According to V. Rimsky's definition, corruption («cruel» corruption) is the benefit of one's position in the system of state power or of one's associated social status for selfish purposes, by any means and under any circumstances. It also refers to «any action that contributes to the decomposition of state power and public administration, the destruction of mechanisms that ensure the functioning of power structures in the public interest, in the formation and strengthening of mechanisms for their functioning solely in personal or corporate interests, as well as in the interests of very narrow social groups» ${ }^{15}$.

As for politics, they talk about political corruption. According to Y. Nisnevych, «political corruption is defined as the use by a person holding public office of his or her powers and rights, official position and status in the system of public authority, the status of a public authority he represents for the purpose of unlawfully obtaining a personal and/or group, including for the benefit of third parties, political gain (political enrichment) ${ }^{16}$. It can take the form of «hard» and «soft» corruption.

It is possible to distinguish the main features of political corruption, namely: the subjects of political corruption are public officials, local selfgovernment bodies, representatives of political and public organizations (parties, parliamentary factions, blocs, public organizations, etc.).; subjects

\footnotetext{
${ }^{14}$ Хутов К. М. Лоббирование, коррупция, монополизм: исследование криминогенного взаимовлияния. Преступность и коррупция: современные российские реалии: сборник научных трудов / под ред. Н. А. Лопашенко. Саратов: Сателлит, 2003. С. 273-284.

15 Римский В. Л. Бюрократия, клиентелизм и коррупция в России. Общественные науки и современность. 2014. № 6. С. 71.

${ }^{16}$ Нисневич Ю. А. Электоральная коррупция в России: политико-правовой анализ федеральных избирательных кампаний в 2003-2012 годах. Москва: Фонд «Либеральная миссия», 2014. C. 4. URL: http://www.liberal.ru/upload/files/Elektoralnaya\%20korrutsiya.pdf.
} 
of political corruption set, first and foremost, political goals, that is, the preservation, receipt, division, strengthening of state power as the highest form of political power; subjects of political corruption use methods and measures (abuse of office, access of official authorities, graft, bribery, etc.), for which penalties are provided for in the current criminal law ${ }^{17}$.

\section{The impact of certain forms of informal destructive political practices on democratic transit in the post-Soviet space}

One of the most common informal political practices and forms of «soft» corruption is «clientelism» (patron-client relations). As J. Scott notes, although actual use of the terms «patron» and «customer» is largely confined to the Mediterranean and Latin American regions, similar relationships can be found in most cultures and most clearly present in pre-industrial nations. Patron-client relationships can be defined as a separate type of dyadic communication (that is, involving two persons) using an instrumental friendship in which a person of higher socio-economic status (patron) uses his or her own influence and resources to provide protection or benefits to the individual lower status (client), which in turn reciprocates by offering general support and assistance, including personal services, to the patron ${ }^{18}$.

V. Rimsky gives the following definition of clientelism - «a social phenomenon characterized by the formation of relations of prepotance, domination and subordination, dependence and independence on the principle of patron-client. In this relationship, one party - the patron - is the protector and the other - the client - is patronized. The status of the parties to these relationships is very situational and changeable: patrons and clients are interdependent, and in some cases, for example, clients have the ability to force the patron to act in their interests, limiting their own» ${ }^{19}$.

In the system of patron-client relations, the more influential party (patron), who may occupy a high position in the system of government, provides «services» for the less status «client» in exchange for, for example, intangible benefits. Patronage is a distribution of resources by a ruling group

\footnotetext{
17 Тіньков А. Л. Запобігання і протидія політичній корупції в системі державного управління України: Автореф. дис. на здобуття наук. ступеня к-та наук $з$ держ. упр.: 25.00.02. Київ: Національна академія державного управління при Президентові України, 2013. C. 9. URL: http://academy.gov.ua/NMKD/library_nadu/Avtoreferat/32f72418-a3b6-4af99044-46f80c8aef29.pdf.

${ }^{18}$ Scott J. C. Patron-client Politics and Political Change in Southeast Asia. The American Political Science Review. 1972. № 1. Vol. 66. P. 92. URL: http://www.la.utexas.edu/ users/chenry/pmena/coursemats/2009/Scott-1972-clientelism.pdf.

${ }_{19}$ Римский В. Л. Бюрократия, клиентелизм и коррупция в России. Общественные науки и современность. 2014. № 6. С. 74.
} 
to attract election votes or other political support. Participation in patronclient relations is only partially voluntary and often imposed by the patron, acquiring the characteristics of «offer that can not be refused». According to the opinion of S. Barsukov, the patron-client relationship is «involuntary as a result of their hierarchical disposition, which measures the degree of dependence of the subjects and the range of exchangeable goods» ${ }^{20}$. Patronclient relationships are built on a kind of trust, which, however, is not universalistic.

Institutions of patronage are aimed, first and foremost, at achieving private (rather than group) goals rather than common goals and objectives for society. L. Roniger points out the «subversive» role of clientelism in relation to formal public institutions: «patrons and clients are not interested in equal relations or formal rules, their interest concerns specific individuals. They are not interested in setting general rules for all citizens, but rather in using specific situations for their own benefit. Thus, patron-client networks are used to abuse public resources» ${ }^{21}$.

Patron-client relationships can be spread across four levels: interpersonal personal; group (most often within tribal communities and clans - a phenomenon characteristic of traditional societies); at the state level as a whole (when patronage practices begin to play a significant role in the system of resource allocation, elite rotation and substitution mechanisms); supranational (international organizations and intergovernmental associations) ${ }^{22}$. The last two levels have the greatest danger for the processes of democratic transformation.

According to the opinion of M. Afanasyev, such relations are a kind of «airbag» in the conditions when political, financial or any other social upheavals occur, since their invariability is expressed in the peculiarities of functioning. Being held in a liberal democracy, patron-client relations are an indicator not only of the efficiency of the institutions of power, but also to some extent of social maturity and well-being of society ${ }^{23}$. Political connections and «trust receipts» form a different set of relationships between group members, forming interest groups and pressure groups whose origins cannot be explained by the official's functional responsibilities.

\footnotetext{
${ }^{20}$ Барсукова С. Ю. Реципрокные взаимодействия. Сущность, функции, специфика. Социологические исследования. 2004. № 9. С. 27.

21 Roniger L. Civil Society, Patronage and Democracy. International journal of comparative sociology. 1994. Vol. 35. № 3-4. P. 213.

22 Torsello D. Clientelism and Social Trust in Comparative Perspective: Particularism versus Universalism. International Journal of Humanities and Social Science. 2012. Vol. 2. № 23. P. 73-77.

23 Афанасьев М. Н. Клиентелизм: историко-социологический очерк Политические исследования (Полис). 1997. № 1. С. 162.
} 
Clientelism can take many forms. R. Kaufman points to the main characteristics of patron-client relationships: a) such relationships emerge between actors with unequal power and status, b) these relations are based on the principles of reciprocity; c) such relations are of a private nature and are to a small extent guided by public law or public norms ${ }^{24}$. L. Lomnitz believes that patron-client relationships are «a form of reciprocity in which clients benefit in exchange for loyalty and subordination to senior patrons ${ }^{25}$. Some researchers, such as $\mathrm{S}$. Barsukov, propose to distinguish reciprocity (as a special type of social integration - «exchange of gifts between members of the social horizontal network») from clientelism in a number of parameters, such as: specificity of coercion to this type of relationship, duration in time, degree of autonomy from formal institutes ${ }^{26}$.

The peculiarity of the reciprocity phenomenon is that the exchange occurs horizontally and is a manifestation of friendship and to some extent an equal exchange. Participants in this process are linked through formal ties, but the gift itself, in its essence, its signifance and value vary, depending on the context.

Some authors highlight patronage as a separate form of informal destructive political practices. While clientelism is more about the interpersonal relationships of two individuals with different status, patronage, in turn, is often attributed to the redistribution of resources to different groups by a person related to the state apparatus. According to the opinion L. Roniger, «clientelist agreements are built on asymmetric but mutually beneficial and time-limited transactions that underlie participants' access to various resources in a stratified society» ${ }^{27}$.

In the context of variations on the theme of the relationship between the patron and the client a significant and widespread practice during political transit is «favoritism» (from the Latin favor - mercy) - the appointment of services or the provision of resources to relatives, acquaintances, in accordance with belonging to a particular party, race, religion, sect, and

${ }^{24}$ Kaufman R. R. The Patron-Client Concept and Macro-Politics: Prospects and Problems. Comparative Studies in Society and History. 1974. Vol. 16. № 3. P. 295. URL: https://www.cambridge.org/core/journals/comparative-studies-in-society-andhistory/article/patronclient-concept-and-macropolitics-prospects-andproblems/479DDF41BB86BF811586783FD621604F.

${ }^{25}$ Lomnitz L. A. Informal Exchange Networks in Formal Systems: A Theoretical Model. American Anthropologist. 1988. Vol. 90. № 1. P. 45. URL: https://anthrosource. onlinelibrary.wiley.com/doi/abs/10.1525/aa.1988.90.1.02a00030.

${ }^{26}$ Барсукова С. Ю. Реципрокные взаимодействия. Сущность, функции, специфика. Социологические исследования. 2004. № 9. С. 20.

27 Roniger L. Civil Society, Patronage and Democracy. International journal of comparative sociology. 1994. Vol. 35. № 3-4. P. 211-212. 
other groups, which negatively affects the quality of public activity and promotes inefficient and unfair distribution of public resources among those with special access to public office.

As S. Paramonov notes: «The phenomenon of the favorite determines the roles that intuitively perform social actors (individuals, groups and communities), which are characterized by the «clutch» of informal ties and the creation of a single sanctioned field of action of surrounding individuals ${ }^{28}$. Favoritism is an opportunity for a career lift as well as a direct influence on the political situation. If most informal practices are shrouded in a veil of secrecy, then this phenomenon has some publicity: as a rule, the name of the favorite is on everyone's lips, and its role in the political process is well-known.

Favoritism, as a rule, causes a similar chain reaction: if a leader chooses to put in the top positions of their favorites, then they do the same, take to themselves the deputies of their already authorized persons - their favorites. There is a circular bail.

A particular form of favoritism is nepotism (from the Latin «Nepos», nepotis - grandson, nephew), when the leader prefers to nominate for the position of his relatives and next of keen. That is, nepotism is a system of power built on affinity.

A close to nepotism form of informal political practices is cronyism - a system of government that relies on relations between friends.

Cronyism has two forms of propagation - instrumental and relational. Instrumental cronyism aims at fulfilling tasks of a utilitarian nature and satisfying self-interest. The relational form of cronyism is based on partnerships, friendships, loyal and loyal attitude of the subordinate to the leader, which further develops into providing unreasonable advantage, benefits and profits, and also manifests in making unreasonable decisions ${ }^{29}$.

Cronyism and nepotism lead to such things as: big deals when concluding deals, appointing relatives for key posts, preferential purchases of personal property, access to hard currency and more. Control over these areas of business creates the preconditions for using them for corruption. The distribution of such benefits is carried out among a small group of elites and their families, who are expected to return in the form of bribes and other «thanks». Corruption in the family circle is not as big as trade bribes and patronage systems.

${ }^{28}$ Парамонова С. П. Антикризисные меры: «за» и «против» института фаворитизма. Вестник Пермского национального исследовательского политехнического университета. Социально-экономические науки. 2009. № 4. С. 148.

29 Діденко І. Непотизм, фаворитизм та кронізм як причини виникнення конфлікту інтересів. Підприємництво господарство $i$ право. 2017. № 8. С. 104 . URL: http://pgp-journal.kiev.ua/archive/2017/8/22.pdf. 
Nepotism and cronyism are most often manifested during:

- subsidies - public funds provided to a company or industry, in view of the need to adjust the market, which the government considers to be a «failure», enabling a company or industry to obtain more than ordinary conditions, profit or increase its profitability;

- refinancing when the government spends money to support a business that is having problems trying to counteract the consequences that these problems can cause;

- granting government loans or payments offered by the government on preferential terms to specific companies or industries;

- government setting tariffs (import or export tax, state-set prices, creating market barriers) that protect certain industries or businesses;

- securing special interests through abuse of law to approve and preserve business interests;

- in the phenomenon of "revolving doors», that is, the relationship between legislators or regulators and the industries they regulate, which imply the transition of persons employed by regulators to work in enterprises that they once regulated, and vice versa;

- licensing of professional activity - granting permission from a governing body that is required for a particular activity ${ }^{30}$.

Thus, we can talk about the interdependent status of favoritism, nepotism, cronyism as a relation of the whole and the part. All these privileged states are directly related to explicit («hard») corruption, but they cannot be identified.

The use of nepotism has led to the existence of clan relations. And it should be noted that this tendency is inherent in a number of post-Soviet countries. It significantly impedes the processes of democratic transit and even facilitates a reverse movement (to the formation of authoritarian tendencies).

The collapse of the Communist Party, the collapse of the USSR, and the subsequent political transit of the post-Soviet countries led to increased influence by regional elites pursuing their own goals, regardless of ties with formal institutions.

As a result of such processes, post-Soviet politics in a number of new states has acquired a clannish trait where leaders of large clans have authority not through high positions but through the ability to own and distribute economic and administrative resources among clan members. Thus, such leaders gained institutional status, and formal institutions were

30 Cronyism in America. Freedom Partners: website. URL: https://www.freedompartners.org/issues/cronyism-in-america/. 
often replaced by informal relationships. Clans in a number of post-Soviet countries have undermined legitimate state institutions and the power system as a whole ${ }^{31}$.

Therefore, it is crucial that administrative and other reforms in modern Ukraine aim at limiting and eliminating such destructive informal practices. Such measures will enhance the processes of democratization.

Consider this a form of informal political practice. The clan (a genus or related group related to economic and social ties) is the strongest form of solidarity of bloodline and patronage-client integration, the identification of individuals that has prevailed for millennia and has grown from a traditional primitive society. At the same time, it is the most dangerous and destructive form of elite grouping and recruiting for undeveloped democratic societies, since here the unifying basis of people are not personal properties and virtues, but casual biological and natural relations of affinity, nepotism, friendship, etc. As a result, the nation is weakened, divided into many competing families, tribes, their segregation, inequality and injustice, which lead to an ethnos of self-destruction.

Another form of «soft» corruption is localism or regionalism - activities aimed at securing wholly or mainly local, local interests at the expense of broader regional, interregional, nationwide, civic and other public interests ${ }^{32}$.

It should be noted that the term «localism» can be used to describe not only economic but also political corruption that produces separatism (Abkhazia, South Ossetia, Transnistria) and creates frozen conflicts. Ukraine has experienced in its experience this phenomenon in the Crimea and the Donbass, when with foreign military support from the Russian Federation in 2014 it led to catastrophic consequences: annexation of the Crimea and the war in the Donbass.

Tribalism is another form of informal destructive practices that significantly exacerbates authoritarianism in many post-Soviet countries). It has many manifestations: patronage of the representatives of his tribe in the state apparatus, low level of ethnic processes, tribal enmity, desire to deal only with representatives of his tribe ${ }^{33}$. Earlier the term was used in relation to Africa and Oceania, and nowadays it is often referred to as the practice of public relations in the territory of post-Soviet Central Asia.

31 Шкель С. Н. Неформальные институты в политическом процессе постсоветских государств. Фундаментальные исследования. 2014. № 12. С. 1585.

32 Сулакшин С. С., Максимов С. В., Ахметзянова И. Р. Государственная политика противодействия коррупции и теневой экономике в России. Монография в 2-х томах. T. 1. Москва: Научный эксперт, 2008. URL: http://rusrand.ru/files/books/ Protivod_Korrupcii_T1.pdf.

33 Дадабаева 3. Партийно-политическая система в Узбекистане, Таджикистане и Туркменистане. Россия и мусульманский мир. 2008. № 12 (198). С. 78. 
Political tribalism involves the penetration of certain ethnic groups related to tribal principles into public authorities and their influence on decisions at national and local levels ${ }^{34}$. It should be noted that such influence is exercised in the interests of these groups.

The transition from clan, tribalism and localism to particularism (regionalism) and separatism occurs quite naturally as the necessary conditions mature and (consciously or unconsciously) weaken legitimate forms of public communication. Legislative introduction of the concept of normative (mandatory) ethnic (national) proportional representation in the authorities (both local and state) is practiced in many countries) ${ }^{35}$.

An example of this phenomenon is the experience of a number of postSoviet countries, such as Kazakhstan, where according to 2000 data, the Senior Zhuz controlled 23, the Medium - 13, and the Junior - 6 senior state posts. Natives of the Senior Zhuz were the President, the Prime Minister, the President of the Presidential Administration, the Speaker of the Lower House of Parliament (Majilis), the National Security Committee, the Customs Committee, the Central Election Commission, the Minister of Defense, Foreign Affairs and others. ${ }^{36}$ As a result, the level of representation of the Middle Zhuz in the authorities decreased significantly, and the Junior Zhuz was pushed to the political periphery.

Within the Senior Zhuz, the closest environment (the «family») was dominated by N.A. Nazarbayev, which included his daughter Dariga, who controlled up to $90 \%$ of the country's information space through the media holding «Khabar» («News»); her husband, the son-in-law of President Rakhat Aliyev, who chaired the National Security Committee during this period; nephew Kairat Satibaldi and second son-in-law Timur Kuleybaev, who respectively managed KazakhOil and KazakhTransoil corporations ${ }^{37}$. According to the Expert magazine for 2006, all economic assets, except the oil industry, were consolidated within the ruling clan. The approval of the

34 Кыдыралиева М. Р. Трайбализм как социальное явление (на материалах Кыргызстана): автореф. дисс. на соискание уч. степени к-а филос. наук: 09.00.11. Бишкек, 2015. C. 9. URL: http://cslnaskr.jet.kg/collections/uploads/Автореферат_Кыдыралиева\%2 0Миргул\%20Рысбаевна.pdf.

35 Сулакшин С. С., Максимов С. В., Ахметзянова И. Р. Государственная политика противодействия коррупции и теневой экономике в России. Монография в 2-х томах. T. 1. С. 72-80. Москва: Научный эксперт, 2008. URL: http://rusrand.ru/files/books/ Protivod_Korrupcii_T1.pdf.

${ }^{36}$ Амрекулов Н. Жузы в социально-политической жизни Казахстана. Центральная Азия $u$ Кавказ. 2000. № 3(9). URL: https://www.ca-c.org/journal/cac-092000/16.Amrek.shtml.

${ }^{37}$ Власть в Центральной Азии: семьи, кланы, жузы [12.07.2006]. Радио Свобода. 2001. 26 июля. URL: http://www.svoboda.org/programs/RT/2001/RT.072601.asp. 
«family» was required by all major business projects implemented in the republic ${ }^{38}$.

Tribalism in Turkmenistan is most clearly expressed in the rivalry of the clans of the Ahal Oasis, in which Ashgabat is located, with clans of other regions.

Genetically, every Turkmen tribe (about 30 of them and more than 5,000 generic groups) is a fairly tight, distinct subpopulation. The Nation of Tribes is made up of ethnographic groups so divided that each one can, in principle, be referred to as an independent small nation ${ }^{39}$.

The most striking examples of tribalism in Turkmenistan include the following: 1) in December 2015, authorities banned entry to the capital of non-urban vehicles; 2) in 2016, de jure, the President of Turkmenistan secured the requirement to streamline the system of renting apartments in Ashgabat (most of the tenants are representatives of other regions, that is, other Turkmen tribes, as a result, they were simply evicted from the rented apartments), etc. ${ }^{40} ; 3$ ) the leaders of the republic carried out a personnel policy of support to the representatives of their tribe. Only when the head of state changed, did his environment, practically the whole administrative apparatus, change; since Niyazov's time there has been a practice of appointing heads of regions and regional units of law enforcement agencies, representatives of Ashgabat, rather than locals.

\section{Destructive factors of democratic transit in Ukraine: forms of manifestation and ways of overcoming them}

According to Ukrainian political analyst Ivan Symonenko, the process of society's tribalization is a disturbing symptom of entering into socialcivilizational backwardness ${ }^{41}$. The absence in the society of civilized rotation of personnel is replaced by a number of assignments defined by nepotism, localism, tribalism in an environment of purely personal relations.

The state of social consciousness can create prerequisites for the development of favoritism and nepotism, when the level of trust in formal

\footnotetext{
${ }^{38}$ Шустов А. Постсоветский трайбализм - клановые элиты стран Центральной Азии. ЦентрАзия: веб-сайт. URL: http://www.centrasia.ru/news2.php?st=1208944620.

${ }^{39}$ Грозин А. Элиты Туркменистана и центральноазиатские кланы: общее, особенное и трудности модернизации. Азия $u$ Африка сегодня. 2010. №9. URL: http://www.perspektivy.info/print.php?ID=72647.

40 Нарастающий трайбализм. Хроника Туркменистана: веб-сайт. URL: https://www.hronikatm.com/2016/02/narastayushhiy-traybalizm/.

${ }^{41}$ Модернизация и трайбализация на постсоветском пространстве: вместе или врозь? Информационное агентство ИА REX: веб-сайm. URL: http://www.iarex.ru/articles/ 11890.html.
} 
institutions and the level of interpersonal trust in the state and society are very low.

Nepotism and cronyism often lead to the artificial creation of management positions and even entire departments for relatives. Favorites may not be available for long periods of time, be responsible for anything, be transferred to subordinates, while receiving much higher salaries than salaries. This reduces the level and quality of management, creates artificial obstacles to development.

Therefore, the establishment of an independent Ukraine, first of all, required combating similar phenomena, which reflects the legislation.

Ukrainian legislation, for example, Art. $25^{1}$ of the Labor Code of Ukraine as of $07.01 .2017^{42}$ or Art. 32 of the Law of Ukraine «On Civil Service» of 10.12.2015 (as of 05.01.2017) ${ }^{43}$ etc., implies restriction of joint work of relatives and next of keen in one enterprise, in one institution or organization. However, statutory restrictions on the joint work of relatives primarily relate to positions of direct subordination, control or dependence and work related to the ability to make decisions regarding other businesses where close relatives of an official work. That is, a person can be recruited to another department, administration, division, unit, etc. The procedure for imposing such a restriction on state-owned enterprises shall be established by law. And in non-state-owned enterprises, such restrictions are imposed by the owners at their discretion ${ }^{44}$.

The use of nepotism leads to the formation of clan relations. Representatives of different political forces are often linked by family ties, which transforms the hierarchy of the political system into a «tangle» of confusing family ties, which does not contribute to the effectiveness of representative institutions, including political parties ${ }^{45}$. Domestic researchers say that favoritism, nepotism, blat, patronage and clientelism, bribes and

\footnotetext{
${ }^{42}$ Кодекс законів про працю України: Закон України від 10.12.1971 р. № 322-VIII (ред. від 07.01.2017 р.). Офіиійний сайт Верховної Ради Украйни. URL: http://zakon3.rada.gov.ua/laws/show/322-08.

43 Про державну службу: Закон України від 10.12.2015 № 889-VIII (ред. від 05.01.2017). Офіиійний сайт Верховної Ради Украйни. URL : http://zakon5.rada.gov.ua/laws/show/889-19.

${ }^{44}$ Сахань О. М. Проблема непотизму в сучасному українському суспільстві. Вісник Національного університету «Юридична академія України імені Ярослава Мудрого». 2017. № 2(33). C. 191.

45 Політологія: сучасні терміни і поняття. Короткий навчальний словник-довідник для студентів ВН3 I-IV рівнів акредитації. 3-тє вид., випр. і доп. Уклад.: В. М. Піча, наук. ред. Л. Д. Климанської, Я. Б. Турчин, Н. В. Хоми. Львів: Новий світ-2000, 2014. С. 255-256.
} 
bribery and trade in influence were among the most common forms of corruption transactions during $1991-2013^{46}$.

The practice of combating nepotism as a threatening phenomenon for democratic development has been appropriately enshrined in international legal acts. The UN Convention against Corruption ${ }^{47}$ nepotism is considered a manifestation of corruption that harms society and the state. Nepotism is defined by a person's acquisition of new positions or advantages not because of his / her high professional abilities, but because of his / her involvement in a certain social environment.

National legislation also contains rules aimed at preventing corruption and other informal political practices. Thus, the Law of Ukraine «On Prevention of Corruption» (Article 27 «Restrictions on the Collaborative Work of Close Persons») states that persons applying for positions are obliged to inform the management of the authority in the position in which they are applying about employees of the body close to them ${ }^{48}$. The provisions of the Laws of Ukraine «On Civil Service» are also aimed at combating nepotism (Article 12) ${ }^{49}$ and «On Local Government Service» (Article 12) ${ }^{50}$. By «close persons» the law refers to «spouses, children, parents, siblings, grandparents, grandchildren, adoptive parents, adoptive parents, as well as others connected by common life and have mutual rights and obligations ${ }^{51}$.

An example of nepotism in Ukraine, some analysts called the personnel policy of the President of Ukraine V. Yushchenko, which was based on the emotions and desires of the first person of the state and its environment ${ }^{52}$. As a result, the phrase «beloved friends» has become widespread in the Ukrainian political discourse to refer to a managerial system with

\footnotetext{
${ }^{46}$ Копистира А. М. Типологія корупції в Україні. Інноваційна економіка. 2013. № 8. C. 43-46. URL: http://www.nbuv.gov.ua/j-pdf/inek_2013_8_8.pdf.

${ }^{47}$ Конвенція ООН проти корупції. Офіційний сайт Верховної Ради України. URL: http://www.zakon1.rada.gov.ua/laws/show/995_c16.

${ }^{48}$ Про запобігання корупції: Закон України від 14.10.2014 № 1700-VII. Офіиійний сайт Верховної Ради України. URL: http://zakon5.rada.gov.ua/laws/show/1700-18.

49 Про державну службу: Закон України від 10.12.2015 № 889-VIII (ред. від 05.01.2017). Офіиійний сайт Верховної Ради Украӥни. URL: http://zakon5.rada.gov.ua/laws/show/889-19.

${ }^{50}$ Про службу в органах місцевого самоврядування: Закон України від 07.06.2001 № 2493-III. Офіційний сайт Верховної Ради Украйни. URL: http://zakon3.rada.gov.ua/laws/show/2493-14.

51 Рабінович С. Неформальні практики публічної влади як форма дії фактичної конституції. Вісник Національної академії правових наук України. 2013. № 3 (74). С. 108116. URL: http://www.nbuv.gov.ua/j-pdf/vapny_2013_3_16.pdf.

52 Дорош Л., Івасечко О. Непотизм як політико-правова проблема українського державотворення. Humanitarian vision. 2015. Vol. 1. Num. 1. C. 16. URL: http://nbuv.gov.ua/UJRN/hv_2015_1_1_5.
} 
widespread nepotism and clientele associated with the head of state. Therefore, the declared requirements for management personnel, such as professionalism, patriotism and integrity, have been sidelined. At the forefront were those who matched the main and most essential characteristic of any candidate for leadership - belonging to "theirs», which should outweigh all other characteristics and virtues ${ }^{53}$. During the rule of $\mathrm{V}$. Yanukovych in the political and economic system of Ukraine, a specific personalized entity, which in the information and analytical publications is designated as the Presidential «Family» ${ }^{54}$. Directly family and steady friendships, or time-tested business relationships, have become the sole criteria for selection in personnel policy. Therefore, the management of V. Yanukovych's presidency was completely controlled by relatives solely for the benefit of the «family».

Investigating how such informal practices affect policy effectiveness in the country is difficult, but one can say that such a «web» significantly slows down the movement to democracy, reducing people's trust in formal institutions and their desire for effective support for social reform. This breeds disbelief in social elevators and transparent competitions, creating the belief that the position will be occupied by relatives or godfathers of the dismissed person under any circumstances. And so, there is a brain drain, narrowing democratic prospects. Unfortunately, such negative practices are still present in Ukrainian politics, according to the researchers of personnel policy of different national leaders ${ }^{55}$.

Consequently, the presence of such processes contributes to the emergence of corruption within any sphere, and the mechanism of horizontal spread contributes to an increase in the number of corruption crimes. This process will continue until the sphere of corruption is completely affected ${ }^{56}$.

The effect of the spread of corruption, similar to disease, is expressed in its overall multiplication by increasing the number of corruption equipment and persons involved in it, is called contagiousness. It occurs both at the micro level - between individuals within the «closed» system and at the macro level - between regions, countries, etc.

\footnotetext{
53 Лосєв І. Симулякри української демократії. Український тиждень. 2011. 3 червня. URL: http://www.tyzhden.ua/Politics/23922.

54 Рабінович С. Неформальні практики публічної влади як форма дії фактичної конституції. Вісник Національної академї правових наук України. 2013. № 3 (74). C. 108-116. URL: http://www.nbuv.gov.ua/j-pdf/vapny_2013_3_16.pdf.

55 Малко Р. Мандат у спадок. Украйнський тиждень. 2014. 24 жовтня. URL: http://www.tyzhden.ua/Politics/121928.

${ }^{56}$ Борцев В. В. Коррупция : контагиозность, последствия и методы противодействия: дисс...канд. экон. н.: 08.00 .01 (01). Москва, 2014. С. 27-31.
} 
Macro-level contagiousness is expressed in the spread of corruption across regional boundaries and is called inter-regional contagiousness. It arises for three reasons: processes of globalization and widespread business activity have led to a high level of integration, which is why there is a high likelihood of corruption among individuals with intense business contacts; the spread of corruption is possible through cross-border organized crime activities; formed opinion on the actual extent of corruption by citizens of one region generates their expectations for future growth. Corruption is transmitted to citizens of other countries due to social inter-regional interactions ${ }^{57}$.

In 2009, a cross-country survey was conducted in 123 countries $^{58}$. It has shown that the scale of the contagiousness effect of corruption is decreasing with increasing geographical distance. And, importantly, the contagious effect turned out to be just and in the opposite direction, that is, with the reduction of corruption in one of the countries, there are corresponding changes in the neighboring countries. A key determinant of the spread of corruption, as the results of the study prove, was close political contact.

The phenomenon of contagiousness of corruption is a relatively new trend in the field of studying the basic phenomenon of corruption. There is every reason to believe that there is a direct effect of the spread of corruption both between territorial entities within the country and between neighboring countries.

The decisive factor in the latter case is the proximity of the characteristics of the institutional environments or the commonality of the identified political culture. Thus, intergovernmental contagiousness of corruption is more likely to occur in the event of additional unifying institutional, political or economic characteristics.

An effective anti-corruption policy is a prerequisite for overcoming the contagious effect of corruption (both «hard» and «soft»). Here it is necessary to agree with I. Myloserdna that the necessary steps of such a policy are: becoming a society as an equal partner in the development and implementation of the national strategy for combating corruption; involvement of various civil society institutions in anti-corruption counteraction $^{59}$. However, in our view, it is precisely because of the effect of contagiousness that not only civil society institutions within the state but

${ }^{57}$ Becker S., Egger P., Seidel T. Common political: Evidence on regional corruption contagion. European Journal of Political Economy. 2009. 25 (3). P. 300-310.

${ }^{58}$ Ibid.

${ }^{59}$ Милосердна І. М. Участь громадянського суспільства у протидії корупції:досвід країн Центрально-Східної Європи. Політичне життя. 2019. № 3. С. 41. 
also the structures of global civil society need to be involved in cooperating in the sphere of overcoming certain informal destructive political practices.

\section{CONCLUSIONS}

Thus, at the present stage, the use of informal destructive political practices is a significant threat to democratic transformations, a prerequisite for the hybridization of the political regime and the reverse movement of transformation processes toward authoritarianism.

Therefore, given the negative experience of several countries, Ukraine needs to pursue a policy of preventing nepotism, favoritism, cronyism, tribalism and other forms of «soft» corruption in order to prevent political conflicts and successfully democratize society.

Investigating the phenomenon of the contagiousness of corruption leads to the conclusion that only close cooperation and exchange of experience between countries will allow to combat effectively informal destructive political practices, since reducing their manifestations in one country will facilitate similar processes in neighboring countries.

As shown by the analysis, informal relationships, which are a deviation from the norm and can cause significant damage to the political system and society as a whole, at the same time appear to be a form or a way of «smoothing» conflicts between the norms of various kinds and rational law. They are able to correct temporarily the shortcomings of socio-political institutions, allowing some of them relatively adequately, functionally, to work. However, appropriate formal practices aimed at democratization must finally be established and implemented.

An effective anti-corruption policy is one way of overcoming informal destructive political practices, one of which should be to limit the spread of such practices. It is based on two basic conditions, the neglect of which makes the implementation of any initiative absolutely fruitless: the manifestation of the strongest political will and the unambiguous and undisputed rule of law and uniformity of law for each and everyone.

The negative effects of these phenomena require not only the development of means of combating corruption, but also changes in the political consciousness of society in order to prevent the effects of both «hard» and «soft» corruption in the contagious (rapid) effect; to destroy established practices of lobbying of individual and group interests, decisionmaking for the benefit of persons empowered with power or their environment. In our country, such changes will reduce manifestations of policy hybridization and accelerate transformation processes on the path of democratization. 
The constructive socio-political changes necessary for political transit towards democracy, able to combine the formal and the positive informal, can be combined in the concept of «parity democracy». Building such a model of democracy is the key to democratic transit, providing equal rights and equal opportunities for all policy makers.

At the present stage of social development, the problem of achieving parity in society remains urgent in many countries. Despite the theoretical research, in the practical plane the situation is determined by a high degree of negative dynamics and manifestations of mass public dissatisfaction with the actions of the authorities. Today, we see this even in the example of many developed European countries. Sometimes tension is inspired not only by the presence of internal factors, but also by external interventions through the use of negative informal practices such as corruption, falsified or false information on social networks, etc. All this requires constant attention and effective control by the state and society and a clear awareness of both the positive and the negative aspects of the combination of formal and informal in the political process, above all, during the phase of democratic transit.

\section{SUMMARY}

Constructive and destructive factors of democratic transit are considered. The concept and essence of informal political practices are analyzed, the main approaches to their definition are considered. The criteria for the typology of such practices are clarified, their constructive and destructive forms are determined. The division of informal destructive political practices into corruption («hard» corruption) and other forms («soft» corruption) is justified. Forms of «soft» corruption include clientelism, patronage, favoritism, nepotism, cronyism, lobbying, clannishness, localism, political tribalism and others. The analysis of manifestations of such forms of informal destructive political practices as favoritism, nepotism, cronyism, clanism and tribalism in the post-Soviet space is analyzed. The essence of the effect of the contagiousness of corruption is found out. Two groups of post-Soviet countries are identified with differences in prevalent forms of «soft» corruption. It is proved that in the western republics of the former USSR individual practices prevail (clientelism, favoritism, nepotism and cronyism), in the eastern regions - collective (clan and tribalism). It is justified that to create effective mechanisms for overcoming all forms of informal destructive political practices, taking into account the effect of contagiousness, is possible only if a model of parity democracy is built in Ukraine. 


\section{REFERENCES}

1. Becker S., Egger P., Seidel T. Common political: Evidence on regional corruption contagion. European Journal of Political Economy. 2009. 25 (3). P. 300-310.

2. Cronyism in America. Freedom Partners: website. URL: https://www.freedompartners.org/issues/cronyism-in-america/.

3. Helmke G., Levitsky S. Informal Institutions and Comparative Politics: A Research Agenda. Perspectives on Politics. 2004. Vol. 2. Issue 04. P. 725-740. URL: https://wcfia.harvard.edu/files/wcfia/files/ 883_informal-institutions.pdf.

4. Karklins R. Typology of Post-Communist Corruption. Problems of Post-Communism. 2002. Vol. 49. № 4. P. 22-32. URL: http://pdc.ceu.hu/archive/00001528/01/03Karklins\%5B1\%5D.pdf.

5. Kaufman R. R. The Patron-Client Concept and Macro-Politics: Prospects and Problems. Comparative Studies in Society and History. 1974. Vol. 16. № 3. P. 284-308. URL: https://www.cambridge.org/core/journals/ comparative-studies-in-society-and-history/article/patronclient-concept-andmacropolitics-prospects-and-problems/479DDF41BB86BF81 1586783FD621604F.

6. Lauth H.-.J. Informal Institutions and Democracy. Democratization. 2000. Vol. 7. № 4. P. 27-43.

7. Lomnitz L. A. Informal Exchange Networks in Formal Systems: A Theoretical Model. American Anthropologist. 1988. Vol. 90. № 1. P. 42-55. URL: https://anthrosource.onlinelibrary.wiley.com/ doi/abs/10.1525/aa. 1988.90.1.02a00030.

8. Roniger L. Civil Society, Patronage and Democracy. International journal of comparative sociology. 1994. Vol. 35. № 3-4. P. 207-220.

9. Scott J. C. Patron-client Politics and Political Change in Southeast Asia. The American Political Science Review. 1972. № 1. Vol. 66. P. 91113. URL: http://www.la.utexas.edu/users/chenry/pmena/coursemats/2009/ Scott-1972-clientelism.pdf.

10. Torsello D. Clientelism and Social Trust in Comparative Perspective: Particularism versus Universalism. International Journal of Humanities and Social Science. 2012. Vol. 2. № 23. P. 73-77.

11. Амрекулов Н. Жузы в социально-политической жизни Казахстана. Центральная Азия и Кавказ. 2000. № 3(9). URL: https://www.ca-c.org/journal/cac-09-2000/16.Amrek.shtml.

12. Афанасьев М. Н. Клиентелизм: историко-социологический очерк (II). Политические исследования (Полис). 1997. № 1. С. 157-166. 
13. Барсукова С. Ю. Реципрокные взаимодействия. Сущность, функции, специфика. Социологические исследования. 2004. № 9. С. 20-29.

14. Борцев В. В. Коррупция : контагиозность, последствия и методы противодействия: дисс...канд. экон. н.: 08.00 .01 (01). Москва, 2014. $151 \mathrm{c}$.

15. Будко Д. А. Политические практики взаимодействия органов региональной власти в современной России: дисс... канд. полит. н.: 23.00.02. Санкт-Петербург, 2014. 192 с. URL: https://disser.spbu.ru/ disser2/disser/Dissertazija_BudkoDA.pdf.

16. Власть в Центральной Азии: семьи, кланы, жузы [12.07.2006]. Радио Свобода. 2001. 26 июля. URL: http://www.svoboda.org/programs/ RT/2001/RT.072601.asp.

17. Грозин А. Элиты Туркменистана и центральноазиатские кланы: общее, особенное и трудности модернизации. Азия и Африка сегодня. 2010. № 9. URL: http://www.perspektivy.info/ print.php?ID=72647.

18. Дадабаева 3. Партийно-политическая система в Узбекистане, Таджикистане и Туркменистане. Россия и мусульманский мир. 2008. № 12 (198). С. 78-102.

19. Діденко I. Непотизм, фаворитизм та кронізм як причини виникнення конфлікту інтересів. Підприємництво господарство $i$ право. 2017. № 8. C. 103-106. URL: http://pgp-journal.kiev.ua/archive/2017/8/22.pdf.

20. Дорош Л., Івасечко О. Непотизм як політико-правова проблема українського державотворення. Humanitarian vision. 2015. Vol. 1. Num. 1. C. 13-20. URL: http://nbuv.gov.ua/UJRN/hv_2015_1_1_5.

21. Кармазіна М., Шурбована О. «Інститут» та «інституція»: проблема розрізнення понять. Політичний менеджмент. 2006. № 4. C. $10-19$.

22. Кодекс законів про працю України: Закон України від 10.12.1971 р. № 322-VIII (ред. від 07.01.2017 р.). Офіційний сайт Верховної Ради Украӥни. URL: http://zakon3.rada.gov.ua/laws/show/322-08.

23. Конвенція ООН проти корупції. Офіиійний сайт Верховної Ради України. URL: http://www.zakon1.rada.gov.ua/laws/show/995_c16.

24. Копистира А. М. Типологія корупції в Україні. Інноваційна економіка. 2013. № 8. C. 43-46. URL: http://www.nbuv.gov.ua/jpdf/inek_2013_8_8.pdf.

25. Кормич Л. І., Краснопольська Т. М. Основні напрями стратегії впровадження моделі паритетної демократії в сучасній Україні. Актуальні проблеми політики. 2018. Вип. 62. С. 6-26. 
26. Коррупция: политические, экономические, организационные и правовые проблемы. Ред. В. В. Лунеева. Москва: Юристь, 2001. 426 с.

27. Кыдыралиева М. Р. Трайбализм как социальное явление (на материалах Кыргызстана): автореф. дисс. на соискание уч. степени к-а филос. наук: 09.00.11. Бишкек, 2015. URL: http://cslnaskr.jet.kg/ collections/uploads/Автореферат_Кыдыралиева\%20Миргул\%20Рысбаев на.pdf.

28. Лосєв I. Симулякри української демократії. Украӥнський тиждень. 2011. 3 червня. URL: http://www.tyzhden.ua/Politics/23922.

29. Малко Р. Мандат у спадок. Український тиждень. 2014. 24 жовтня. URL: http://www.tyzhden.ua/Politics/121928.

30. Мамчуева Ф. Ю. Формальные и неформальные политические практики современного политического процесса. Историческая $u$ социально-образовательная мисль. 2013. № 5(21). С. 150-153.

31. Меркель В., Круассан А. Формальные и неформальные институты в дефектных демократиях. Полис. 2002. № 2. С. 20-30.

32. Милосердна I. М. Участь громадянського суспільства у протидії корупції:досвід країн Центрально-Східної Свропи. Політичне життя. 2019. № 3. С. 37-43.

33. Модернизация и трайбализация на постсоветском пространстве: вместе или врозь? Информационное агентство ИА REX: веб-сайт. URL: http://www.iarex.ru/articles/11890.html.

34. Нарастающий трайбализм. Хроника Туркменистана: вебcaüm. URL: https://www.hronikatm.com/2016/02/narastayushhiytraybalizm/.

35. Нисневич Ю. А. Электоральная коррупция в России: политико-правовой анализ федеральных избирательных кампаний в 2003-2012 годах. Москва: Фонд «Либеральная миссия», 2014. 204 с. URL: http://www.liberal.ru/upload/files/Elektoralnaya\%20korrutsiya.pdf.

36. Парамонова С. П. Антикризисные меры: «за» и «против» института фаворитизма. Вестник Пермского национального исследовательского политехнического университета. Социальноэкономические науки. 2009. № 4. С. 146-172.

37. Подхомутникова М. В. Неформальные политические практики в современной России: субъекты институционализации: автореф. дисс. на соискание уч. степени к-та полит. н.: 23.00.02. Краснодар, 2010. 27 c. URL: http://cheloveknauka.com/v/ 335868/a?\#?page $=27$.

38. Політологія: сучасні терміни і поняття. Короткий навчальний словник-довідник для студентів ВНЗ I-IV рівнів акредитації. 3-те вид., 
випр. і доп. Уклад.: В. М. Піча, наук. ред. Л. Д. Климанської, Я. Б. Турчин, Н. В. Хоми. Львів: Новий світ-2000, 2014. 516 с.

39. Про державну службу: Закон України від 10.12.2015 № 889-VIII (ред. від 05.01.2017). Офіиійний сайт Верховної Ради України. URL : http://zakon5.rada.gov.ua/laws/show/889-19.

40. Про запобігання корупції: Закон України від 14.10.2014 № 1700-VII. Офіційний сайт Верховної Ради Украӥни. URL: http://zakon5.rada.gov.ua/laws/show/1700-18.

41. Про службу в органах місцевого самоврядування: Закон України від 07.06.2001 № 2493-III. Офіційний сайт Верховноӥ Ради України. URL: http://zakon3.rada.gov.ua/laws/show/2493-14.

42. Рабінович C. Неформальні практики публічної влади як форма дії фактичної конституції. Вісник Національної академї правових наук України. 2013. № 3 (74). С. 108-116. URL: http://www.nbuv.gov.ua/j-pdf/vapny_2013_3_16.pdf.

43. Римский В. Л. Бюрократия, клиентелизм и коррупция в России. Общественные науки и современность. 2014. № 6. С. 65-84.

44. Сахань О. М. Проблема непотизму в сучасному українському суспільстві. Вісник Національного університету «Юридична академія України імені Ярослава Мудрого». 2017. № 2(33). С. 189-209.

45. Сулакшин С. С., Максимов С. В., Ахметзянова И. Р. Государственная политика противодействия коррупции и теневой экономике в России. Монография в 2-х томах. Т. 1. Москва: Научный эксперт, 2008. URL: http://rusrand.ru/files/books/Protivod_Korrupcii_ T1.pdf.

46. Суханов В. А. Коррупция в органах государственной власти как глобальная проблема. Вестник МГИМО. 2013. № 4(31). С. 212-218.

47. Тіньков А. Л. Запобігання і протидія політичній корупції в системі державного управління України: Автореф. дис. на здобуття наук. ступеня к-та наук 3 держ. упр.: 25.00.02. Київ: Національна академія державного управління при Президентові України, 2013. 23 с. URL: http://academy.gov.ua/NMKD/library_nadu/Avtoreferat/32f72418a3b6-4af9-9044-46f80c8aef29.pdf

48. Хутов К. М. Лоббирование, коррупция, монополизм: исследование криминогенного взаимовлияния. Преступность $u$ коррупция: современные российские реалии: сборник научных трудов / под ред. Н. А. Лопашенко. Саратов: Сателлит, 2003. С. 273-284.

49. Циганов В. «Загроза політичної корупції у демократичних політичних режимах». Аналітична записка. Національний інститут стратегічних досліджень. URL: http://old2.niss.gov.ua/articles/882/.

50. Шкель С. Н. Неформальные институты в политическом процессе постсоветских государств. Фундаментальные исследования. 2014. № 12. C. 1582-1585. 
51. Шустов А. Постсоветский трайбализм - клановые элиты стран Центральной Азии. ЦентрАзия: веб-сайт. URL: http://www.centrasia.ru/news2.php?st=1208944620.

\section{Information about the author:}

Krasnopolska T. M.,

$\mathrm{PhD}$ in Political Sciences, Associate Professor, Associate Professor at the Department of Political Theories of the National University «Odessa Law Academy»

2, Academichna str., Odesa, 65009, Ukriane 
DOIhttps://doi.org/10.36059/978-966-397-158-2/67-82

\section{CONFLICT FACTORS IN A TRANSIT SOCIETY}

\section{Zavgorodnya Yu. V.}

\section{INTRODUCTION}

Transit society becomes an intermediate stage in the development of state-building processes, in the formation and establishment of government bodies, in the establishment of a democratic system of interaction of government with citizens. Society is changing and forming a virtually new system of authorities, their hierarchy and mechanism of functioning. At this stage, all changes participants, even passive ones, face misunderstandings and conflicts.

As European countries already have a transit practice, we can speak of the occurrence of recurrence of conflicts in different societies, which requires a thorough generalized analysis and practical universalism for political science and the practical competence of political actors during a conflict in the transit space.

Of course, there are theories in science that do not need to be proved that in state-building processes political conflict constitutes an integral part of the development of the political system, which causes the opposite political parties to improve the level of interaction between the authorities and the society, and thereby stimulate all political subjects to self-improvement. Confrontation, as a social phenomenon, is an integral part of the functioning, and most importantly, of the development of the population and the politicians themselves.

Political transformations continue to evolve and provide the basis for scientific analysis and interpretation in political science. It was in the 1980s that political change began in the direction of the democratic political process.

For the Ukrainian scientific community of political scientists, the issue of transit Ukrainian society is still relevant, as an example of the development of public consciousness and political thought, together with the example of delaying the transition and the emergence of a number of conflict situations, which are the reasons for this. In recent years, we have seen dynamic shifts in the direction of the democratic political system in the management of state-making processes. The transition of society from one political regime 
to another is undoubtedly accompanied by political crises and political conflicts. Today, the political system is beginning to be updated, there is a change of personnel, various directions of action of independent public organizations are being formed, a free form of expression is emerging regarding political subjects and political processes.

Of course, if a comparative analysis of Ukraine with similar transitional processes of other democratic states is to study the political system in the context of the Ukrainian state, it is an indicator of a protracted political process in the direction of socio-political changes.

In the modern geopolitical process, many democratic states are emerging, which are formed as a result of the change from a totalitarian and authoritarian form of government to a democratic one. These are signs of a general civilizational development of the world, which is formed as a result of the maximum modernization of the experience of mankind, and not only in individual countries of the world. Unfortunately, the processes of modernization do not reduce military confrontation, confrontation in the context of interpersonal interaction, conflicts over border demilitarization and many other factors. A number of contradictions are emerging into modern forms of confrontation and influence over one another and become even more dangerous.

When forming a democratic political regime, one should not forget and preserve the heritage of culture as the identification of a nation. An important task for the Ukrainian country, as a state in transition, is to preserve the cultural heritage that has historically emerged in Ukraine. In turn, the task of the entire Ukrainian people is to respect and commemorate traditions and values in different historical periods.

\section{Political conflict in the context of a transit society}

After the collapse of the Soviet Union, a fateful transition begins for statesmen and the entire population, and changes in all socio-political processes take place. All these events are accompanied by difficult conflict processes, protracted crises in the political actions of individual politicians. Such volatile and ambitious processes of politicians and influential citizens of the country delay this process.

Scientists determine the cause of this delay by a sudden process of change, without training the population and managers. Of course, this thesis is quite debatable, since the Ukrainian people have always sought to be independent and substantive, and in fact, throughout their history, people who lived in Ukraine tried to identify themselves, to stand out. That is why, since ancient times, in the conditions of continuous conflict confrontation, a 
group of people has been formed in society, who identify themselves as the people of this land, and therefore require isolation and self-ownership in their own territory.

Considering the vast majority of historical processes regarding the transition to a democratic political regime, there are a number of reasons that delay and plan to slow down this process in the country. Scientists call all these processes of inhibition «factors» or «reasons», «causes», but from this their essence is unchanged. In many countries that have experienced the transition, there are universal, i.e. similar causes of delay, but there are specific causes of delay in a specific territory or individual people. The Ukrainian people have both universal and specific reasons for delaying the transition process.

Conflict, as a manifestation of public opinion and self-expression, is an extreme and rather dangerous form of confrontation in society. There are no conflict-free political processes, there will always be dissatisfied and pessimistic groups of people.

Therefore, political conflicts are increasingly occurring in modern society and, as a rule, do not bring positive results and progress in the development of state-building processes in Ukraine, but rather refer them to countries with unstable legal framework, economically unstable and socially vulnerable state system. ${ }^{1}$

As a result, the grounds that influence the increase of social tensions in Ukrainian society are impoverishment of the vast majority of the population, lack of trust in all public authorities, specific relations between branches of government that publicly influence each other's powers given to them by the state, confrontation between parties, their leaders and others.

In the modern world, conflicts are global in nature and are a natural phenomenon. Therefore, in the event of a conflict in one country, the neighboring country will take all diplomatic measures so as not to affect its internal political system in any way. Given the large-scale value of research and resolution of conflict processes in society for the transit country, it is important to identify prerequisites, objective and subjective causes, motives of conflicts, modeling, search for the best ways to resolve in a timely manner, localization, conversion from violent form to non-violent, prevention which is maturing, not following it. All these circumstances are very important for domestic politics.

Of course, the very nature of conflict in a transit society has to do with understanding the essence of man, his relationship with society and the state.

${ }^{1}$ Білецька Ю. В. Теоретичне визначення політичних конфліктів у сучасній Україні. Актуальні проблеми політики. 2013. Вип. 48. С. 199. 
Any conflict, as it arises in society and exists between people, is always social in nature, that is, a social conflict in the broad sense of the word. In such an interpretation, the conflict is positioned as the collision of two or more different forces in order to realize their social interests in the face of mutual opposition. ${ }^{2}$

The term «conflict» comes from the Latin word «conflictus», which means «collision» in direct translation, and in arbitrary - «opposition», «confrontation». Therefore, scientists define conflict through the concept of antinomy (contradiction) or the concept of struggle (confrontment). Exemplary in this aspect is the explanation of the concept of conflict, proposed by L. Gerasina and M. Panov, who define it as «a manifestation of aggravation of objective and subjective contradictions, which is reflected in the confrontation of its carriers, i.e. the parties» ${ }^{3}$.

Taking into account the peculiarities of political conflict in the society and the peculiarities of the transit society, it can be noted that the longer the conflict process is active and continuous, the longer the transition process is, and the political system is unstable and changeable.

In turn, state power in a transitory conflict society is a weapon of protection and the exercise of power interests. It is worth emphasizing that it is the power interests that arise in the state. Therefore, the most significant difference between political conflict and other social conflicts is that the actors acting in it confront or oppose each other for the main reason - power, control or division. This is the goal pursued by modern political actors in Ukraine. The authorities do not solve the problematic issues, but delay their process (for example, the conflict in the East). In addition, political conflicts arise where interests affect political relations ${ }^{4}$.

Developing a successful country's strategy and tactics is a task for politicians and the community to interact with, and this is not possible without recognizing conflict as an integral part of achieving the set goals. A person's consciousness is capable of critical thinking, and therefore the expression of dissatisfaction is a manifestation of a rational awareness of reality. Such discontent is possible when society does not fully possess objective information about socio-political processes and systematic deception breeds aggression.

\footnotetext{
${ }^{2}$ Бодун Т. І. Особливості феномена конфлікту в державному управлінні. Економіка та держава. 2010. № 5. С. 96.

${ }^{3}$ Бодун Т. І. Особливості феномена конфлікту в державному управлінні. Економіка та держсава. 2010. № 5. С. 96.

${ }_{4}$ Станкевич І. П. Політичний конфлікт та технологія його запобігання. Вісник Київського начіонального університету ім. Т. Шевченка : Філософія. Політологія. 2007. № 87-88. C. 71 .
} 
Thus, a transit society is an indicator of changes in the minds of both society and authorities. When the authorities or society cannot adjust to change, conflicts, dissatisfaction, aggression, and unlawful actions arise that give rise to a lack of confidence between the parties to the conflict. During the reformatting of the political system, changes do not take place in one event (for example, the proclamation of the Act of Declaration of Independence of Ukraine or the approval of the Decree on Non-Nuclear Status). The event of regulatory approval and public announcement is the beginning of future actions, positive or negative.

Since the establishment of an independent Ukrainian state, all major events have taken place under serious contradictions and disputes between politicians and political forces. Adoption of the Basic Law of the state, the Constitution of Ukraine, was accompanied by long discussions and conflicts. The Verkhovna Rada of Ukraine worked continuously for almost 24 hours and as a result, on June 28, 1996, at 9:18 am the Constitution of Ukraine was adopted. Although the Declaration of Independence of Ukraine was adopted on August 24, 1991. For the whole 5 years, the Ukrainian state operated on the basis of the legislation of the Ukrainian SSR. The Basic Law is still incomplete and some of the rules do not apply in practice, although these are rules of direct effect.

In addition, Ukrainian legislation continues to enforce the normative legal acts the Ukrainian SSR. For example, the Housing Code of the Ukrainian SSR, which was adopted in 1983, has been amended several times (the last amendments on January 1, 2019) and is still in effect, and problems in the field of housing and communal services are increasing and not being resolved.

Of course, Ukraine's long membership in the totalitarian Union is one of the reasons for the difficult transition, but it is not an excuse for the Ukrainian statehood and political figures.

For example, consider Lithuania, which independence was recognized in September 1991. The country then joined the UN and the OSCE in 1992. NATO - in 2002, European Community - in 2004. In addition, the updated Constitution was adopted by a nationwide referendum on October 25, 1992. That is, this example follows a clear and sure sequence of actions by political figures on the development of the state, and society takes all measures to support those actions.

Another striking example for the Ukrainian state is the neighboring country of Poland, which was weakened during the Union period, but since the beginning of geopolitical changes in the 1980s and 1990s, Poland has been clearly defining its vector of development, namely developing the 
economy and the administrative sphere and becoming able to join the European Union on May 1, 2004, but does not stop there and on December 21, 2007 becomes a member of the European Union and NATO bloc, joined the Schengen area.

It is worth noting that practically all countries had equal chances and opportunities after the collapse of the Soviet Union to develop their potential, and Ukraine may have had greater chances, resources and opportunities. Due to the economic focus of these resources on the presentday Russian Federation, political forces and individual politicians did not want drastic changes, but rather made the most of the country's full potential for their own purposes. A large-scale privatization of large enterprises has started and it is holding up to date. Privatization of Ukrzaliznytsia, possibly one of the only state-owned enterprises, is on the agenda. The question is quite debatable, there are a number of positive and negative factors.

All statements that the country was not ready for independence, just an excuse for weak politicians, because it fought for independence for a long historical period, a striking example of this is the adoption and proclamation of the first Constitution of Philip Orlyk, who proclaimed the independent country Ukraine by this document. It consists of a preamble and 16 articles. In today's political process, it is seen as a monument of Ukrainian political, philosophical and legal thought. This document did not come into force as it was written in the conditions of exile, but it shows the direct struggle and efforts of politicians and society of that period to the recognition of Ukrainian independence, the impetus to democratization.

The current Ukrainian political reality has a multi-sectoral focus, and all political forces in particular see the development of the Ukrainian state. Integrity, indivisibility and unity are the basic principles that should be applied by both politicians and citizens.

Integrity should be interpreted as the territorial demarcation of a border and its recognition by all international actors. It is very difficult to determine priorities for the direction of development of the state if the population living in these territories does not want or support such development. Ukraine should be united and grouped together by most of all regions in achieving the desired direction.

Indivisibility means the absence of any possibility of isolation of a certain group of people in a separate territory, without division into "yours» and «ours». This will mean a constant struggle, the inability to reach a collective solution, frequent unjustified conflicts. Such actions at the present stage cause a prolonged transitional process. 
Integrity, by this principle, should mean cohesion and tolerance of the subjects of the political process. Their will and democratic spirit in all their actions and endeavors. Therefore, unity means not only the unity of political forces in pursuit of a common goal, but also the support of politicians and vice versa.

It is not possible to build a democratic, legal, social state without a nation that supports its politicians, points them the desired path, and directs their actions in the necessary direction. It is not possible to build a democratic society without the transparent actions of the authorities, which in their activities place the priorities of the people above their own and are governed solely by the rules of law. Strong power, strong people, and vice versa, if every citizen assumes responsibility for the actions of elected politicians, then unscrupulous politicians will become less and the state will be improved and developed.

If we talk about the specific reasons that make it impossible for a real transition to a democratic political regime in Ukraine, they have their cultural and ideological features and need detailed analysis. One of these reasons is not being able, or unwilling, to compromise or consensus when addressing socially important issues.

Compromise, in its essence, in political engagement is one of the essential features of a democratic society. It serves as a decisive principle according to which participants or parties to a political process, when resolving political issues, must agree to concessions, be able to sacrifice particular beliefs or attitudes to reach a crucial issue, and show the public the ability to reach mutual acceptance of intentions and decisions ${ }^{5}$.

The phenomenon of compromise in the political aspiration and democratic formation of the country is a powerful means of preventing socio-political, ethnic, international clashes, mitigating confrontation, overcoming internal crises, avoiding a split in society, but in case of such events, compromise helps the parties to overcome the crisis that their relationship has gone through. Mutual consent in socially significant issues, the ability to make concessions is the highest form of compromise in political issues ${ }^{6}$. At first glance, the simple things of adequate social interaction between the subjects of the political process, but so complicated to implement.

5 Козер Л. Функции социального конфликта. Пер. с англ. Москва: Идея-Пресс, Дом интеллектуальной книги, 2000. С. 12.

${ }^{6}$ Козер Л. Функции социального конфликта. Пер. с англ. Москва: Идея-Пресс, Дом интеллектуальной книги, 2000. С. 12. 
Making compromise decisions is an indicator of maturity and readiness to cooperate to achieve the overriding goal of Ukraine's transition to a democratic political regime to enhance the well-being of Ukrainian society. Political conflicts in Ukraine must be limited in intensity and duration. The parties are obliged to act in the interest of the whole society, otherwise the mechanisms of public administration will be deformed to such an extent that they cannot maintain the balance of public interests ${ }^{7}$.

Along with compromise, consensus plays an important role in the political process. The essence of the consensus mechanism of political parties' interaction is the ability to resolve conflicts in political decisionmaking. That is, the parties to the confrontation should be aware that all misunderstandings have a mechanism of settlement and one of them is a common political decision. Such a decision does not force the parties to make concessions, since this does not require the most problematic issue. The key task of the parties is the ability to negotiate and enforce their own decision.

Consensus inherently encompasses the process of interaction between the parties during which the parties made the decision and the most legally declared decision of the parties. Consensus, in its form, is substantially different from other forms of decision-making, for example by voting, but is effective in its implementation. The parties that actually agree with the decision will demand that the decision be enforced by all policy makers and monitor its implementation.

An important factor hindering the transition to a democratic political regime is certain socio-political processes, namely, external and internal events that influence political processes in the state and contradict the attitudes formed by modern government in society. Ukrainian society is very critical and hostile to changes in the political system offered by the authorities, and so there are certain protests that are accompanied by destructive consequences.

If we analyze the process of transition from a totalitarian regime to a democratic one, namely the turning point of the $80 \mathrm{~s}$ and $90 \mathrm{~s}$, we can conclude that the process of dissatisfaction with the totalitarian system of that period took place in a passive form and not as a planned preparation for radical changes in the social, political process. Therefore, the landmarks of

${ }^{7}$ Валевский А. Failed state Ukraine? Украинская правда. 2009. 19 мая. 
socio-economic, ideological, cultural and other directions of development of Ukrainian independent society have not been determined ${ }^{8}$.

Taking into account all the conflicts and socially important contradictions in the political process, we can say that Ukraine is on the path of modernization. All political changes through reforms and revolutions are aimed at changing the political elites and leaders, changing the vector of development of society, changing the functioning of public authorities, changing the interaction between public authorities and citizens, overcoming large-scale corruption in power, limiting the use of power resources in their own interests.

\section{Factors of conflict in the process of modernization of Ukraine}

The process of modernization in Ukrainian society is very important. If the authorities and the population work together to achieve these goals, it will help Ukraine complete the transition process and embark on the path of a democratic legal society. If the parties miss such an opportunity for modernization, the state may remain in the status of a transit, conflict, fragile country with low economic and cultural development for a long time.

Moreover, since Ukrainian society is post-totalitarian, it is important to pay considerable attention to the responsibility for the consequences of political opposition in domestic socio-political transformations by political actors. In accordance with the requirements of a democratic society, all actors who commit criminal acts in relation to statehood and state-building processes should be punished within the framework of current legislation. In order to comply with international legal instruments ratified by Ukraine and national legislation, the state should punish such political actors within the framework of a sanction.

It is also worth remembering that the lack of transparency in the actions of the judiciary and law enforcement agencies has repeatedly caused conflict between citizens, authorities and politicians, and the number of politicians held accountable does not correspond to the actual number of offenses committed by this category of officials.

However, due to the current political and legal situation in the society, with the advent of a large number of military associations and public organizations, direct pressure is exerted on the judicial and law enforcement agencies. When considering criminal proceedings in which certain actors are of interest, judges cannot resolve the case objectively, which causes a

${ }^{8}$ Кіянка І. Реалізація політичної стабільності в процесі трансформації українського суспільства. Українська національна ідея: реалї та перспективи розвитку. 2009. Вип. 21. C. 91-96. 
violation of the principle of democracy. Interested groups of people gather in courtrooms, who begin to disrupt the lawsuit, use obscene language, create pressure and jitters, and thus violate the lawsuit regulated by procedural law, and encourage the necessary decision.

Such conflicting aspects and problems that arise in the process of democratization are traced back to the fact that the elite, which exercised its powers at the time of the establishment of an independent rule of law, acted in a simplified and unilateral manner towards the implementation of reforms, and therefore showed its unwillingness to carry out the task of effective and rapid transition to the democratic regime, which has delayed the transit period and contributed to a number of political conflicts.

The scientific studies and historical events of the independent Ukrainian state trace a number of reasons that made it impossible for a rapid transition of society to the desired political regime.

The basic reasons for changes in the political system of the state are subjective composition. In the Ukrainian society, changes were made mainly by the same staff, which necessitated these changes. All political decisions regarding the transformation of society were made taking into account the interests of individuals, not the entire Ukrainian society.

Modern reforms and targeted programs that are practically hierarchical, i.e. top-down, are often ineffective and do not work in practice. All the norms and tenets of the change process are general in nature and do not have a clear procedure for implementation. The lower structural forms of society do not support the reform of power, since they do not affect the creation of these reforms, which create possible directions for change. Lack of forms of cooperation between authorities at all levels causes conflicts on various socially significant issues.

Another important factor that causes contemporary political conflicts in Ukraine is the illusion of a conflict-free society. For a long period of time, people are not able to apologize publicly, negotiate and discuss problematic issues. The solution of any political conflict, which is inherently a public phenomenon, is made in the national society in «closed offices». In this regard, there is a growing distrust of the authorities, distrust of politicians, distrust of the entire state apparatus at all levels.

Contemporary scholars emphasize the isolation of ideological conflict, which shows the peculiarities of traditional research, and at the same time characterizes the process of state transformation. Ukraine is an exemplary example of such conflict counteraction, since confrontation of ideologies is an important signal for public figures about the possible serious consequences of such conflict, the confrontation in the political process and the irresponsibility of the consequences of the parties' actions. 
Also, in today's Ukrainian society, which is in a virtually indeterminate status regarding the form of government, there is usually always a confrontation between two parties related to the degree of public confidence in the government. Such value-cultural processes are the legitimation and delimitation of the new political regime in society, which include the recognition of political leaders, the renewed structure of state and non-state institutions in society.

The phenomenon of instability of Ukrainian society in the transit period shows us that the process of legitimation and delegitimization is quite relevant, and that society shows its value in state-building events and shaping the direction of the country's development. During such events, the idea is formed that society is not a gray mass, these are communicative and active citizens, intellectually aware.

Socio-political confrontations, dubbed the Revolution of Dignity in the media, are a direct example of the importance of legitimizing power, the people can forgive the authorities for lack of legality, as happened with the authorities after the Revolution of Dignity, but Ukrainian society will not restrain itself if power does not restrain.

Power delegitimation in the Ukrainian political system is a dangerous means of changing power, as it can have uncontrolled actions and therefore lead to unexpected consequences. The government exhausts all the credit of trust and cannot control the socio-political processes, which may eventually end in the collapse of statehood. In a democratic society, legality and legitimacy are the pledge of the power of the people, and therefore these concepts and political actions are not indivisible and interconnected.

In a transition period characterized by a large number of socio-political changes, society forgives the authorities for lack of stability and sharp socioeconomic fluctuations, but these are only temporary phenomena, since the internal instability of the transit society over time contributes to exacerbation of various problems encountered by the population.

One of the key problems of the transition period is the corruption of the authorities at all levels, and the conflict of political decisions is a confirmation of this. Every political force tries to influence some or other political decisions made in the state, in a favorable direction for them. One of the issues that politicians are in no hurry to address is the legitimacy of amber mining. Many media outlets have been covering the confrontation within the framework of illegal amber mining, the issue has become nationwide and still remains unresolved.

Taking into account all the important factors that influence the emergence of conflicts in the transition period of Ukrainian society, it is necessary to emphasize the attention and life circumstances of citizens, historical peculiarities of the society development. The life circumstances of development and functioning are to change the views of individual members 
of society, taking into account objective and subjective reasons, regarding the historical past, the desired future and the improvement of the present. In this context, a new model of national identity is emerging, perhaps even with a dramatic change in cultural and historical values.

V. Gorbatenko notes the existence of the phenomenon of the «Ukrainian model» of post-totalitarian development, which, for all its economic inefficiency, is capable of maintaining peace in the country and avoiding open internal aggression and bloodshed. The formation of such a model takes effect in the exercise of the powers of the first president, L. Kravchuk. Its main purpose is that the authorities wished to maintain social equilibrium while not essentially changing the socio-political system, maintaining the current system and institutions of the authorities, because there was a fear that there would be a disorder in society and the collapse of the administrative system ${ }^{9}$.

The result of the implementation of such a model is, firstly, the absence in the first years of independence of large-scale conflicts, with negative violent consequences, secondly, the lack of development and economic recovery. The country was dominated by fear of the development of conflicts, which persisted from a totalitarian society, because in its normal manifestation conflict is necessary for the democratic development of society. The existence of contradictions in society is characterized by a certain manifestation of the struggle against the outdated totalitarian leadership structures and the formation of civil society.

A society that intends to shape a democratic political regime is bound to fulfill the basic principles that will stimulate change in consciousness, namely: equality of citizens in all characteristics and indicators without restriction and oppression by color, origin, language and religious affiliation. All of these principles in modern Ukrainian society often lead to the development of socio-political and ethnic conflicts that can lead to the most dangerous consequences. From time to time, such confrontations may integrate several factors of conflict and develop nationwide or globally.

Therefore, taking into account all the above, it can be noted that all the factual circumstances that give rise to conflict are reduced to the main generalization, that the main goal of the transit society of Ukraine is to achieve political and economic stability. At the present stage of the existence and functioning of Ukrainian society, it is possible to identify the main changes in the creation of a democratic political society in the country, namely:

9 Долженков О. Посткомуністичні трансформації в країнах Центрально-Східної Європи та СНД: порівняльний аналіз. Нова політика. 2000. № 5. С. 12-13. 
- firstly, there was a change of personnel in the system of public authorities, which contributed to the emergence of new ideas in the interaction of the authorized person and the citizen;

- secondly, values in the Western industrial world began to change in the Ukrainian society during the transformation period, which means that the state in its activity is also beginning to transform and change the vector of development;

- thirdly, in economic terms, there is a need to fulfill certain conditions to achieve the desired result, which would correspond to the level of European countries, because there is a market for domestic goods, and therefore there is a lively competition. Economic factors today often cause credit and currency problems, as a result of rising unemployment and emigration ${ }^{10}$.

Of course, the issue of transit for Ukrainian society will be urgent for an indefinite period of time, since at the present stage there is no effective mechanism for the transition to a democratic political regime, and the consciousness and mentality of citizens, as key levers of democracy, are not geared for rapid changes in all sectors, such as the state and public life in general. Citizens' consciousness and political views are scattered in different directions. Such multidimensionality limits the effective path of transition.

Therefore, the democratic political regime is one of the most important goals for the political authorities and the Ukrainian people, because it is the desire for better political change, the main thing that such desire is for both the political elite and the overwhelming majority of citizens to jointly move towards its achievement.

Modern realities show us that political power also includes interstate ties of individual political forces that are capable of influencing peoples and nations, thereby increasing the geopolitical influence of individual politicians and political forces. The concept of political power goes beyond the interpretation of governing bodies within one country.

In addition, it is worth paying attention to the hierarchy of power and interconnections in the modern information world, since the power hierarchy is changing somewhat.

According to Bulbenyuk S.S. one of the illustrative arguments regarding the need to rethink public authorities' public awareness in the information age is the emergence in the last decades of alternative centers of making important political and managerial decisions - centers of a network nature. The author argues that, like traditional state institutions, political parties, political leaders and elites, such networking centers do not require institutionalization and formalization. The essence of alternative networking

10 Завгородня Ю. В. Особливості розвитку транзитного суспільства в умовах політичного конфлікту. Актуальні проблеми політики. 2018. Вип. 61. С. 235. 
centers is ambiguous, since, on the one hand, such centers can be formed on social networks, which means that they should be as open and public as possible in their activities, and on the other hand, often outside such centers are elite representatives, which do not contain any elements of publicity. Therefore, the general public (those who are commonly called «people», «ordinary citizens», «voters», «civil society») have no idea about the true nature of such representatives of the political elite ${ }^{11}$.

Thus, taking into account S. Bulbenyuk's statement, we can say that the modern political power has changed peculiarities regarding public influence and interaction with the society, and the structure of the government does not have a clear approved pattern of interconnections and rules of behavior regarding the entry into the power structure. The newest aspects of political power are characterized by the presence of informal centers of influence, the lack of power, or even in some places, the unsettled power relations ${ }^{12}$.

Since power has such characteristics in current political processes, there is a certain power struggle, or so-called sphere of influence, on groups of people or regions. The power itself in the process of interaction, due to frequent conflict processes, becomes a state of political crisis, which leads to devastating processes for the entire structure of government.

As E. Toffler wrote in his famous work, The Shift of Power: Knowledge, Wealth, and Violence at the Threshold of the Twenty-First Century, the system of power pervades modern society to the core, no one is free from it $^{13}$. However, if we cannot be free from power, then we must form it in such a way that this power is effective in the interaction of different political institutions and in relation to citizens.

In transitional societies, it is very important that the effectiveness of political power is determined by the results of the implementation of developed plans, programs, its ability to manage effectively all spheres of public life, to achieve political goals by optimal means. There is no universal notion of «power efficiency» in scientific circulation that can be used to define objectively power by quality. Although in its general form, the effectiveness of power is the use of all possible levers of influence to satisfy the interests of citizens. Therefore, if the government uses leverage to satisfy its own interests, then it is the corruption efficiency of the government that needs radical changes.

11 Бульбенюк С. С. Особливості владно-управлінського дискурсу в інформаційну епоху. Науковий часопис НПУ імені М.П. Драгоманова. 2014. Вип. 14. С. 66.

12 Бульбенюк С. С. Особливості владно-управлінського дискурсу в інформаційну епоху. Науковий часопис НПУ імені М.П. Драгоманова. 2014. Вип. 14. С. 66.

13 Жаровська I. М.Державна влада: правові категорії: Монографія. Львів: Вид-во Львівської комерційної академії, 2012. С. 26. 


\section{CONCLUSIONS}

Considering all the above, we can conclude that the peculiarity of the transit society, besides the struggle for the distribution of powers, for determining the spheres of influence, there are problems regarding the efficiency of the allocation of economic resources in the state. That is why the populist anti-corruption thesis has to move from slogans to actions in order to speed up the transition period.

The current political situation in Ukrainian society demonstrates the most dangerous consequences for the authorities and society as a whole. As conflicts ripen in both society and power, tension and psychological strain on the minds of citizens increases, emotions and aggression often become the norm of communication.

In the current political process, the destruction of political power, which is the result of protracted political conflicts that go into prolonged crisis states, is of great importance, making it impossible for a democratic political regime to emerge.

Thus, transit society is emerging in the face of a series of political conflicts and political crises that have a significant impact on the process of modernizing the political system.

Authorities are pushing for positive change by improving their knowledge, skills and abilities. Conflict over key forms of development limits the ability to improve quickly the political system, and parties to conflict are unwilling to compromise on a swift settlement.

Conflicts are the way to find a way to democratize the political system and society. Changing the political regime is not only a change of the elite, it is also an awareness of the responsibility of every citizen who is a power, not an instrument of power in the old political elite.

\section{SUMMARY}

In scientific research on the signs of conflict in a transit society, scientific analysis of political confrontation in the historical context of political events and political decisions that influence the further development of society is of great value. The main tasks are to carry out a comparative analysis of the factors of conflict in post-totalitarian countries, to create a list of causes of conflict with the definition of their influence on a transitional society, and to analyze the Ukrainian society as a stable transit country. The source of the conflict is not only the cause of the delay in the transition process in society, but also the factor of destructive processes, which have a negative component in the development process. The analysis of current problems will help to determine what priorities should be taken by the political elite during the process of transformation in the political consciousness of one's own and society as a whole. 


\section{REFERENCES}

1. Білецька Ю. В. Теоретичне визначення політичних конфліктів у сучасній Україні. Актуальні проблеми політики. 2013. Вип. 48. С. 199208.

2. Бодун Т. I. Особливості феномена конфлікту в державному управлінні. Економіка та держава. 2010. № 5. С. 96-100.

3. Бульбенюк С. С. Особливості владно-управлінського дискурсу в інформаційну епоху. Науковий часопис НПУ імені М.П. Драгоманова. 2014. Вип. 14. С. 66-70.

4. Валевский A. Failed state Ukraine? Украинская правда. 2009. 19 мая.

5. Долженков О. Посткомуністичні трансформації в країнах Центрально-Східної Європи та СНД: порівняльний аналіз. Нова політика. 2000. № 5. С. 12-16.

6. Жаровська I. М. Державна влада: правові категорії: Монографія. Львів: Вид-во Львівської комерційної академії, 2012. 195 с.

7. Завгородня Ю. В. Особливості розвитку транзитного суспільства в умовах політичного конфлікту. Актуальні проблеми політики. 2018. Вип. 61. С. 226-235.

8. Кіянка I. Реалізація політичної стабільності в процесі трансформації українського суспільства. Українська національна ідея: реалії та перспективи розвитку. 2009. Вип. 21. С. 91-96.

9. Козер Л. Функции социального конфликта. Пер. с англ. Москва: Идея-Пресс, Дом интеллектуальной книги, 2000. 208 с.

10. Станкевич І. П. Політичний конфлікт та технологія його запобігання. Вісник Київського національного університету ім. Т. Шевченка : Філософія. Політологія. 2007. № 87-88. С. 71-73.

\section{Information about the author: Zavgorodnya Yu. V., $\mathrm{PhD}$ in Political Sciences,} Associate Professor at the Department of Political Theories of the National University «Odessa Law Academy» 2, Academichna str., Odesa, 65009, Ukriane 
DOI https://doi.org/10.36059/978-966-397-158-2/83-102

\section{THEORETICAL BACKGROUND OF THE RESEARCH OF THE TRANSITION TO DEMOCRACY PROCESS}

\section{Myloserdna I. M.}

\section{INTRODUCTION}

The modern political world has been complex and controversial for thousands of years. The socio-political organization of human society was changing, mechanisms of interaction between peoples were updated and complicated. And since the legacy of the past is manifested in one way or another today, one can only understand events that take place in the political space by reference to their essence and content. One such event in the political world is the process of transition to democracy. The problem of the establishment and development of democratic foundations has been central to political science and has been addressed for a long time to a greater or lesser extent. In the 1980s and 1990s, the interest of researchers in the problems of democracy and the factors that caused it rose again. This is partly due to the fact that democratization, which took place in a number of regions of the world, was accompanied by trends not previously inherent in the formation of democracy. And thus, new political realities have created an additional impetus for researchers: a new subject area of analysis is formed, and thus the situation of controversy and reflection on new theoretical approaches to it.

We can agree with O.V. Babkina, who at the present stage of understanding the problems of the transition to democracy in political science is carried out in the framework of the transitological approach, which emerged during the neo-institutional turn of the 1980s-90s and the expansion of the theory of rational choice from economics to political science and social theory. The transitological paradigm focuses not on the objective conditions and preconditions of democracy, but on the activities of the main political actors - above all, the strategic choices and actions of political elites ${ }^{1}$.

1 Бабкіна О.В. Передумови переходу до демократії: ризики транзитивного суспільства. Науковий часопис НПУ імені М. П. Драгоманова. Серія 22. Політичні науки та методика викладання соціально-політичних дисциплін. 2015. Вип. 17. - С. 3-11. URL: http://enpuir.npu.edu.ua/bitstream/123456789/22598/1/Nchnpu_022_2015_17_3.pdf 
Consideration of the process of transition to democracy involves the study of the phenomenon of political transit as an object of scientific research and comparative analysis of models of the process of transition to democracy.

In the broad sense, the analysis of the modern meanings and the origin of the word «political transit» makes it possible to say that its content consists in the transformation of the totalitarian or authoritarian political-state system of the state towards the development of the general level of democracy in the state and society.

\section{The phenomenon of political transit as an object of scientific research}

The study of the phenomenon of political transit should begin with the observation that, according to some scholars, the «transitological paradigm» represents only a shy resurrection from the dead of the very theory of modernization that prevailed in the 1950's and 1960's, and the characteristic feature of which was the differentiation of the political structure (institutionalization), which envisaged the formation of an extensive network of socio-economic, political and other institutions of society aimed at ensuring stability and social order, but which in the 1970s revealed its intellectual bankruptcy ${ }^{2}$. In this case, the main feature of this situation is the disorder and decline of the types of knowledge used to understand and justify this worldview. It is precisely from these conditions that the concept of «political transit» emerged as a reflex to criticize the abstractness of modernization theory.

Political transit as a process began to be seen as the substantive essence of modernization, revealing the internal content in the political part. This is understood as political transit in the broad sense. In a more narrow and special sense, political transit in modern political science is the process of transitioning the state-political system from a less perfect in a democratic sense to a more sophisticated and advanced form of democracy, encompassing the political organization of society and the political system of the state. The phenomenon of global political transit is a so-called process of global democratization.

In the theoretical analysis of the phenomenon of political transit, one can agree with I.R. Khintba, who believes that in the development of political transitology it is decided to distinguish three stages: the end of the 1960's 1980 's - an analysis of societal transformations takes place, and the starting point is D. Rastow's work «Transitions to democracy: an attempt at a

\footnotetext{
2 Капустин Б. Г. Конец «транзитологии»? (О теоретическом осмыслении первого посткоммунистического десятилетия). Полис. Политические исследования. 2001. №4. С. 7.
} 
dynamic model»; the end of 1980-the second half of 1990 - an analysis of the fall of communist regimes in the USSR and the countries of Central and Eastern Europe, and among the leading scholars of this period it is worth noting S. Huntington and A. Pshevorsky; end of 1990 - present - analysis of transitional processes in certain countries of Central and Eastern Europe, which are ambiguous and lasting.

As S. Huntington points out, the history of society is such a stream of various events that different processes of political transformation do not have the capacity to self-distribute over strict historical temporal centers. In general, Huntington's approach makes it possible to understand in general terms the development of the process of global democratization and the extent of this phenomenon. Before researching the phenomenon of political transit, its constituents and features, it is necessary to pay attention to the methodological question of the study concerning the interaction of the concepts of «political transit» and «political transformation».

Literally, transformation (Latin - trans and formatio) means the modification or alteration of the appearance, shape, structure or essential properties and characteristics of an object. ${ }^{3}$ Political transformation means the acquisition by the political system of new features, changes in political standards and values; radical structural changes aimed at achieving a qualitatively new state of the system ${ }^{4}$. In the context of this study, political transit, unlike political transformation, is a broader process. Considering transit as a process of systemic transformation of the general spheres of society and the state as a whole, political transformation is seen as a major part of transit, encompassing mainly qualitative changes in the institutional and procedural mechanisms of functioning of the political system. It should be noted that this part of the transit is one of the most important. Based on this understanding of the two terms, they can be used in close relation as they reflect in a particular political segment and within separate time frames relatively similar political processes. According to the opinion of V.Ya. Gelman, justification for this approach may also be dictated by the fact that today, in search of an adequate interpretation of political changes in the CIS countries, transit theories are changing and transforming. The theorist also uses the terms «transit» and «transformation» as synonyms ${ }^{5}$.

${ }^{3}$ Современный словарь иностранных слов: около 20000 слов. СПб. Дуэт. Комета. 1994. С.617-618.

${ }^{4}$ Новейший политологический словарь / Д. Погорелый, В. Фесенко, К.Филиппов. Росто-на Дону. 2009. С. 241

${ }^{5}$ Гельман В.Я. Постсоветские политические трансформации (Наброски к теории). Полис. 2001. № 1. С. 20 
Thus, considering the differences of concepts, it is possible to speak meaningfully about the basic elements and characteristics of political transit, which is understood as intermediate quality, the transition of society from one position to another. In this approach, understanding political transit is reduced to defining the period of time by which the state-political system of the country and society itself undergoes fundamental transformation and coordinate changes. In a meaningful sense, political transit correlates with democratic reform of the system of political power and liberalization of the social and political life of the state.

According to the classical canons, five constituent elements of a political transit can be conditionally distinguished:

a) the preconditions for political transit, which are formed under conditions which are directly or relatively ahead of its inception. The preconditions of political transit, as one of the main components of its element, became of particular importance from the very beginning of the separation of transitology into an independent discipline of political science. So one of the «early transitologists», D. Rastow, suggested that «the only prerequisite is national unity» in the country. Of course, this unity is necessary because it is the basis for the reforms the state is going for. Unlike his followers, D. Rastow, in the question of the essence of national unity, was deeper, considering this unity as a community of the nation. He emphasized that «national rhetoric is most often heard from the mouth of those who are least confident in their sense of national identity» ${ }^{6}$. It should be noted that the assumptions of democracy include the acquisition of national unity and corresponding identity; achieving sufficiently high economic development, the widespread dissemination of such cultural norms and values that imply recognition of democratic principles, trust in major political institutions, citizenship and other. In addition, these prerequisites for political transit certainly have some universality, but the experience of transit states shows that not every prerequisite in the obligatory queue exists in all states where there are political transformations.

b) the starting point from which political transit as a process begins. Its presence is conditioned by the fact that the initial state of society is important, as it determines the nature and direction of transit. It is possible to start transit from a totalitarian state of society, but you can have an authoritarian regime with some elements of democracy as a starting point of transit. In this case, it is, first and foremost, that totalitarianism and authoritarianism serve as sort of starting points of transit in certain countries.

${ }^{6}$ Растоу Д. Переходы к демократии: попытка динамической модели. Полис. 1996. № 5. C.5-15. URL: http://read.virmk.ru/R/Rastou.htm 
Diversity and difficulties not least reveal some of the differences in political transit in authoritarian and post-totalitarian states.

Thus, if political transit has a starting point for a totalitarian regime, then its content in general parameters is characterized by the following aspects: dismantling the totalitarian system as a whole, since it is not capable of democratic change in its content; reforms can go both from above and from below; the opposition is rather artificial; There is an initial absence of civil society because totalitarianism is opposite to civil society, but since it acts as one of the conditions for successful political transit, its formation becomes a priority. In conditions where political transit has a starting point for authoritarianism, its content can be filled with the following aspects: authoritarianism is more pluralistic than totalitarianism; allows for the presence of elements of civil society that are necessary for democratization; transit has little risk of slipping into totalitarianism, while post-totalitarian transit has many chances of being interrupted by authoritarianism.

The selected component of political transit - the point of reference - in one way or another, for these forms, is general in nature and influences the whole process of transit.

c) the purpose of transit, that is, the state of society, the political system, the regime of power in which the transit takes place. As a goal of the transition period for transitional societies, most researchers call democracy, and therefore all discussions are centered on ways and means of achieving a democratic social order.

d) the transit process itself, with its specific content, which is determined by its internal stage and content characteristics. The fact is that assuming that consolidated democracy as a goal of political reform is to be achieved by the transit society at the final stage of the process, it is equally important to understand political transit as a sufficiently long and complex process which at different stages may have a gradual and reversed direction. In this sense, in many transitological concepts, political transit is seen as a step-bystep process, in which periods of liberalization, democratization, and the habit of democracy are consistently revealed. Consider the step-by-step and substantive characteristics of transit in more detail.

As researchers of political transit point out, the development of democracy requires not only some experience of democratic traditions, but also the most important, previous, at least not extensive experience of liberalism, even in monarchical or authoritarian form. It turns out that liberalism is a common basis for different types of democratic system of state and society. Thus, it can be stated that for all models of political transit 
the process of liberalization of the whole system of public relations is of great importance.

So O.V. Lukin, notes that I. Bjorlin, the outstanding theorist of liberalism. stressed that freedom exists more fully in the modes of enlightened liberalism than in democracies where the majority has the opportunity to impose its will on the minority. As O.V. Lukin writes, Western authors «have only recently seriously discussed that planting democracy on an unprepared ground not only does not increase the amount of freedoms, but may even help to eliminate the limited liberalism existing for democracy» ${ }^{7}$. It is worth noting that the distinction between these two concepts is fundamental, since democratization entails liberalization, but is a broader and specifically political concept, since it involves open competition for the right to control the government, which in turn allows for free elections that determine composition of the cabinet. Liberalization predominantly modifies the relationship between the state and civil society. And democratization basically disrupts the relationship between the state and political society as such. It is clear that liberalization does not necessarily have to transfer into forms of democratization ${ }^{8}$.

On a temporal scale, liberalism and democratization represent two phases of the overall process. Therefore, they are interdependent, and their sequence suggests that without prior liberalization, there can be no deep democratization of a transit society and democracy cannot be rooted in it. Liberalization is deepening and capturing all new spheres of the public relations system.

In this sense, political transit must be understood not only as a linear, one-dimensional process, but also as a three-dimensional process that develops horizontally and vertically. On this basis, it can be stated that the nature of the interconnection of the processes of liberalization and democratization in a meaningful way reveals the specifics of political transit. After the relatively successful implementation of a liberalizing and democratizing society by society, the process of political transit enters its last, final stage - socialization (consolidation).

In its classic version, this was reflected in the concept of political transit by G. O'Donnell and F. Schmitter, who distinguish the three stages of the transition to democracy from authoritarianism or totalitarianism:

7 Лукин А.В. Переходной период в России: демократизация и либеральные реформы. Полис. 1999. № 2. С. 140.

${ }^{8}$ Stepan A. Democratizing Brasil? Problems of Tranzition and Consolidation. N.Y. Oxford; Oxford University Press, 1989. P.78. 
1) liberalization; 2) democratization; 3) socialization ${ }^{9}$. According to their concept, the step-by-step essence of political transit is that it progressively evolves from «liberalization» to «democratization», with the subsequent deepening of democracy and assimilation by all social groups at the stage of «socialization», which ensures the transition to «sustainable democracy» as the ultimate goal of political transit.

Thus, it can be stated that the development of political transit is subject to the integral logic of transformation of the undemocratic regime into democracy, which was reproduced in the syntactic construction of political transit by O.G. Kharytonova. According to her design, «... the ideal type of transition to democracy is likely to consist of four main stages: 1) liberalization of political life, providing for the institutionalization of civil liberties, controlling the «opening» of the regime; 2) dismantling the most viable institutions of the previous political system; 3) democratization, which is characterized by the formation of the norms, procedures and institutions of the new democratic regime, is considered the main criterion to be free elections ... and the consolidation of the democratic political system; 4) re-socialization of citizens into a new system ${ }^{10}$. In general, in spite of some schematics, this approach of O.G. Kharytonova is relatively functional for the analysis of intra-transit stages.

e) a result that does not always coincide with its purpose. Moreover, in most cases during the «third wave of democratization» the goal is not achieved. Thus, it is not necessary that the transit will result in consolidated democracy. This is due to the fact that in addition to the above characteristics, political transit has such a significant feature as the uncertainty of its procedures and results. This view is, for example, expressed by F. Schmitter, who associates it with the possible threats to the democracies of states of so-called «connected democracies» ${ }^{11}$.

Researchers propose different ways out of uncertainty, among which one would like to point out A. Przeworski, who characterizes the transition to democracy as the «kingdom of uncertainty». Depending on the purpose and resources of the specific political forces and structures that emerged between them in the «uncertainty zone» of conflicts, A. Przeworski identifies five possible outcomes of the transition period: 1) when no democratic institute can assert itself and political forces begin to fight for a new dictatorship;

${ }^{9}$ О’Доннел Г. Делегативная демократия. Пределы власти. 1994. № 2/3. С. 7.

${ }^{10}$ Харитонова О.Г. Генезис демократии (Попытка реконструкции логики транзитологических моделей). Полис.-1996. №5. С.73-74.

${ }_{11}$ Шмиттер Ф. Процесс демократического транзита и консолидации демократии. Полис. 1999. №3. С.31 
2) when no democratic institution can assert itself and yet political forces agree on democracy as a temporary solution; 3) when the established democratic institutions might remain, but competing forces compete for the establishment of a dictatorship; 4) when, in the case of the introduction of some democratic institutions, they could survive, but the opposing political forces agree on a viable institutional structure; 5) when individual democratic institutions might remain, and when they are introduced, they are indeed strong. As can be seen from the list of possible outcomes of A. Przeworski's transition, variants of the final results of political transit, characterized by a high level of uncertainty, can vary over a wide range ${ }^{12}$.

Thus, an analysis of the theoretical views of theorists on the essence of political transit makes it possible to divide them into two groups: some authors emphasized structural factors (above all, state and national, socioeconomic, cultural and value conditions and prerequisites for democracy), and others - procedural factors (especially the choice and sequence of specific decisions and actions of those political actors on whom the democratization process depends).

Representatives of the structural approach identify major correlations between some socio-economic and cultural values and the likelihood of establishing and maintaining democratic regimes in different countries. Such correlations are understood as structural - that is, conditioned by the attention of certain objective structures, and not by the subjective intentions and actions of participants in the political process - the preconditions and conditions of democratization and democracy.

Such correlations are understood as structural - that is, conditioned by the attention of certain objective structures, and not by the subjective intentions and actions of participants in the political process - the preconditions and conditions of democratization and democracy ${ }^{13,14}$. They believe that the actions of political actors who initiate and make democratic transit are not even conditioned by their «objective» position in the public structure. On the contrary, their «subjective» choices themselves create new political opportunities.

It should also be noted that a theoretical and methodological synthesis of structural and procedural approaches to democratic transit is desirable for

12 Пшеворский А. Демократия и рынок. Политические и экономические реформы в Восточной Европе и Латинской Америке. / Пер. с англ. под ред.проф. Бажанова В.А.-М. : РОССПЭН. 1999. С. 222-225.

${ }^{13}$ О’Доннелл Г. Делегитивная демократия. Век XX и мир. 1994. №7. C.189-195 URL: http://old.russ.ru/antolog/predely/2-3/dem01.htm

14 Шмиттер Ф. Процесс демократического транзита и консолидация демократии. Полис. 1999. № 3. С. 30-33. 
political transit research, as it would allow for a broader set of factors and variables to be considered in the analysis and to build more multidimensional models of the processes studied. It can also be argued that finding a possible way to a primary synthesis of this kind may prove futile to have a specific methodology of analysis, first used in the classic work of D. Campbell and his colleagues «American Voter» and called the «causality funnel».

D. Campbell and his co-authors define this analytical methodology as follows: «Imagine a sequence of events, as if they were inside a cavern of causality.... Let us imagine that the funnel axis is this temporary dimension. The events are understood as if they were following one another in a sequence of convergent causal chains, moving from a wide part of the cone to its narrowing.

The funnel shape is the logical result of the task chosen to explain the task. Most of the complex events in the funnel are the result of numerous previous causes. Each of these events, in turn, affects many representations, but our focus of attention narrows as we approach variable dependent behavior. We are gradually eliminating those consequences that cease to influence political action. As we are forced to consider all partial causes as essential at all times, the implications for us are slightly less than their causes. The result is a convergence effect, a convergence at one point ${ }^{15}$. I will note that this methodology was modified for the analysis of tarsive processes of A.Yu. Melville, who noted that according to this methodology, the factors that influence the progress of democratic transit - from the initial liberalization of the regime to the launch of new democratic institutions and procedures - could be analyzed at the following seven conditional levels of variables:

1. External international environment (world economic situation, political and strategic relations), etc.;

2. State and national factors (a single territory and state, a sense of national identity, and the like) - as a condition and precondition for the movement itself to democracy;

3. General socio-economic level of development and modernization of society;

4. Socio-class processes and conditions (measure of differentiation and development of social structure of society);

5. Socio-cultural and value factors, that is, cultural and political values and orientations that dominate in society;

${ }^{15}$ Campbell A., Converse P., Miller W., Stokes D.. The American Voter. N.Y. 1960. 573 p. 
6. Political factors and processes (interaction of parties, socio-political movements and interest groups);

7. Individual, or personal, political and psychological factors (specific actions and volitional decisions of key political actors, as well as their «charismatic») ${ }^{16}$.

Of course, the following question arises: will the description of factors be systematized according to a multidimensional technique with a theoretical explanation adequate to the complexity of the phenomenon itself? Strictly speaking, no. The proposed use of the «causality funnel» methodology cannot replace other scientific pursuits for developing an integrated theory of democratic transit. And the proposed methodological model is only one of the possible ways to find explanations for the essence of the phenomenon of transition to democracy as such, but not these explanations themselves. This is, strictly speaking, the methodological contours of the study, the specific meaningful content of which - for each specific case - may be different.

\section{Comparative analysis of models of the process of transition to democracy}

The theoretical and methodological approaches to the study of political transit, discussed in the previous paragraph, allow us to consider the universal models by which this political phenomenon develops in the modern world. In this case, the model of political transit means a certain dynamic form within which a country or group of states makes the transition from undemocratic forms of administration and government to forms democratic and which reveals the parameters of the subsequent development of transit societies.

The very variety of possible means of political transit with many options for solving problems and problems arising in it, the limit variety of conditions in which the state enters transit, national peculiarities of experiencing painful transformations, inevitable during the transit period, determine the specifics of transit and dictate.

Most clearly this side of political transit is described by S. Huntington's concept, so let's analyze it in more detail. In Huntington's view, the transition to democracy is a process of step-by-step change in the configuration and nature of the interaction of major political actors in the political field of the state. After considering the empirical material, he

16 Мельвиль А.Ю. Опыт теоретико-методологического синтеза структурного и процедурного подходов к демократическим транзитам. Полис. 1998. № 2. С. 6-37 - URL: http://www.politnauka.org/library/dem/melvil.php 
identified three models of democratization of so-called countries of «the third wave».

The «transformation» process is a major model of transition, as 16 of the 35 «third wave» transit states have been democratized with this option. During the «transformation» period, the ruling elite of the transformative regimes plays a crucial role, since it actually initiated the fall of the previous regime and its change to a democratic one.

According to the opinion of S. Huntington, the «transformation» model of transition is typical for Spain and Brazil, and among post-communist countries - for Hungary. Being the most difficultly structured model of the transition to democracy, the process of «transformation» consists of five main phases, four of which are still under authoritarian regime: 1) the emergence of reformers; 2) the coming of the reformers to power; 3 ) contradictory liberalization; 4) consensus with conservatives; 5) co-opting the opposition ${ }^{17}$.

The first signs of the emergence of the first phase of transformation - the «emergence of reformers» - is the emergence of previous or real leaders, which in turn initiate the transition to democracy.

The advent of the second phase of transformation - the «coming of reformers to power» - in its content means the release of democratic reformers from their status of marginalized within authoritarian regimes and the acquisition of full political power. The very arrival of reformers to power marks the beginning of the third phase of transformation - «controversial liberalization».

According to the opinion of S. Huntington, the content of the third phase of transformation is characterized by the pursuit of liberal reforms in the society on the one hand, and the desire to preserve the stability of the liberalized authoritarian system on the other. In other words, in carrying out liberal reforms during this phase, reformers are in no hurry to carry out large-scale democratic reforms in order to preserve the existing authoritarian regime. As a result of such a two-pronged policy, liberal reformers become temporary figures in power, eventually leaving them and giving way to democratic reformers or conservatives.

The further development of the transformation process takes place in its fourth phase, the Consensus with Conservatives phase, which is due to the fact that gaining power allows reformers to start democratization, but does not deny conservatives the opportunity to challenge them. As S. Huntington points out, one of the main conclusions that reformers come to during the

${ }^{17}$ Huntington S. The Third Wave: Democratization in the Late Twentieth Century. Norman and London: University of Oklahoma Press., 1991. P. 235-236 
fourth phase of transformation is the inability to continue their democratic change without some retreat caused by the need to make concessions to the Conservatives.

The fifth phase of transformation - the phase of «co-opting the opposition», according to S. Huntington is characterized by the entry into the political advance of a political force that opposes the reformist regime. At the level of this phase of transformation, the ruling reform elite is losing the possibility of full control of the situation and, as a result, is forced to engage in real dialogue with the opposition.

S. Huntington's second model of democratization of the «third wave» countries - the «replacement» model - is a process very different from the «transformation». It involves three distinct stages: 1) the struggle for the fall of the regime; 2) the fall of the regime; 3) fight after the fall of the regime.

According to the opinion of S. Huntington, until 1990 in the states of the «third wave of democratization» political transformation was under the option of «replacement» only in 6 cases. At the same time, «replacement» was rare in the transition from one-party systems and military regimes and more common in the transition from personal dictatorships.

The third model of the democratic «third power» holder of S. Huntington is the «permutation» model, which is a process that performs the activity between «transformation» and «replacement». In a «reshuffle», the process of democratic political regime is the result of sharing real elites and opposition. At the same time, in the ruling elite, the balance between conservatives and reformers is that it is ready to contemplate regime change, but is not ready to initiate it, as is the case with the replacement model. Thus, the ruling elite must be pushed to formal or informal negotiations with the opposition. According to the opinion of S. Huntington, approximately 11 out of 35 cases of liberalization or democratization fit the model of «permutation». Among them are Poland, Czechoslovakia, Uruguay and others.

The above typological models of S. Huntington's political transit have an undeniable interest, despite the fact that he constructed them on the basis of the processes of global democratization that were characteristic of the 1990s.

It should be noted that the ideas of A. Przeworski, which considers two stages of political transit: liberalization and democratization, are close to the Huntington`s concept. At the same time, it also differentiates the stage of democratization into three stages: «liberation», «construction» and «rivalry». The peculiarity of A. Przeworski's approach is his emphasis on the content and disclosure of the internal conditions of behavior of the parties involved in the interaction during the transit. 
The stage of liberalization of political transit, which is characterized by instability, can take place in two directions, from above or below, depending on what appears before and brightly - a split in the leadership or the force of the mass movement. Liberalization can both bring about change and provoke repression, that is, a return to the strengthening of the previous authoritarian regime. In the event that the changes continue, the next stage of political transit - democratization - will take place, with its first stage of «liberation» from the authoritarian regime. Releasing from the heightened pressure of authoritarianism can be peaceful enough as a result of compromise, forging a mutual understanding between reformers in the middle of an authoritarian bloc and moderate ones in the middle of the opposition. According to A. Przeworski, such a compromise is possible under three conditions: if the reformers and the moderate ones agree on democratic institutions in which the social groups represented by them would have an influence; if reformers can coerce or neutralize solid line supporters; if moderate are able to control radicals in the opposition. At the same time, the latter two conditions logically warn the first, since they determine the possible actions of reformers and moderate.

The second successive stage of democratization - the «construction» of democracy, occurs through negotiation and which can be realized by three options of development: 1) the balance of forces known and inequalities; 2) the balance of forces known and equilibrium; 3) the balance of forces is unknown.

The third successive stage of democratization - the «rivalry», of those who are fighting against authoritarianism goes through pacting, agreement between leaders of political parties. According to A. Przeworski, the goal of such pacts is to protect embryonic democratic institutions by reducing the incidence of conflicts arising from the political course and recruitment in a particular transit society ${ }^{18}$.

In addition to S. Huntington and A. Przeworski, clear examples of a staged model of political transit are reflected in the concept of D. Rostow, who considers the process of democratization in large blocks, according to which political transit goes through three phases: 1) «preparatory», which is a mandatory prerequisite - the existence of national unity, which can take place in prehistoric times, as in Japan and Sweden; may be ahead of other stages of the transition to democracy for centuries, as in France. It is also necessary to create the constitutional laws or parliamentary practices of a

${ }^{18}$ Пшеворский А. Демократия и рынок. Политические и экономические реформы в Восточной Европе и Латинской Америке./Пер. с англ. под ред.проф. Бажанова В.А. - М. : РОССПЭН. 1999. С.230-231 
pre-existing democracy within this phase, but the theorist immediately noted that it is important to create institutions independently, since copying them alone will not produce the desired result; 2) a «decision-making phase» that plays a large role in a transitional society, and democratic decision-making in some sense can be seen as an act of conscious, openly-revealed consensus. In addition, decision-making should be shifted to the level of professional politicians and the general population; 3 ) an «addictive phase» that assumes that democracy is inherently a competitive process, and in the course of competition, preferences are given to those who can rationalize their commitment to the new system, and even more are - those who genuinely believe in it ${ }^{19}$.

Given the fact that the typological models of the transition to democratization of the aforementioned political scientists were designed by them, based on the realities of the period of global democratization until the 1990s, we can give an example of a typological model of the transition to democracy, which was developed under the influence of 1989 events in the countries Central and Eastern Europe. It is an idealistic model for the democratization of T. Karl and F. Schmitter, who view it from the point of view of a formal transition. In their models, the authors identified two main transition parameters: leading actors in the transition process (elite and masses) and actors strategies in the transition process (compromises and power $)^{20}$. Depending on the combination of these parameters, they have identified four models of the transition to democracy: the «model of the pact transition», according to which the main actors are the elites, the strategy is a compromise character. An example of such a model is Spain's political transformation process; a «model of reformist transition», in which the main actors are the masses, whose strategy is a compromise character. An example is the political transformation of Czechoslovakia in 1989; a «model of revolutionary transition», in which the main actors are the masses, who in turn use power strategies. This model was implemented in Russia in 1917; A «coupled transition model» where the main actors are the elite who use power strategies. This model was quite successfully implemented in Brazil in the period of 1974-1985s.

The advantages of one or the other of these transition models vary. T. Karl and F. Schmitter point out that the transition to democracy by the

${ }^{19}$ Растоу Д. Переходы к демократии: попытка динамической модели. Полис. 1996. № 5. C. 5-15. - URL: http://read.virmk.ru/R/Rastou.htm

${ }^{20}$ Карл Т., Шмиттер Ф. Пути перехода от авторитаризма к демократии в Латинской Америке, Южной и Восточной Европе. Международный журнал социальных наук. 1994. № 1. C. 30 . 
models of «revolutionary» and «forced transition» is not usually conducive to democracy. The «reformist transition» model rarely leads to a stable consolidated democracy. The ideal form of transition is depicted by the «pact transition» model when there is an explicit or implicit agreement between «democrats», a moderate part of the opposition and representatives of other segments of the ruling group ${ }^{21}$. And more transitologists agree with the preference for a «pact transition» to democracy.

According to the opinion of V.Ya. Gelman, analysis of these models makes it possible to confirm that, depending on the relation of forces between the leading actors of the political process, several models of transition to democracy can be distinguished and «they are basically reduced to three options: transformation, by which the process of democratization is carried out by the previous ruling elites; the substitution resulting from the collapse of the authoritarian regime and the process of democratization is carried out by the opposition that has come; a mixed version of the process of democratization as a result of the combined actions of the elites and the opposition $^{22}$.

In view of the above, it is expedient to go beyond the system of classification of political transformation models in the analysis of typological models of political transit and to consider these models on the basis of a number of approaches. The adopted classification system allows to group the transition models of the transit countries of the «third wave of democratization» by those attributes of political transit that are characteristic for each of them. This system of classifications includes a number of quantitative and qualitative and formally meaningful approaches in modeling the transformation of the political system and allows to identify 6 typological models of political transit, each of which has in its midst different variants of implementation:

- a dynamic model of transit, the implementation options of which vary in the pace of democratic transformation (in some countries, including Poland, Hungary, the transition to democracy can be characterized as a forced, and the key to the success of democratic transformations is the presence of economic and socio-cultural preconditions, historical experience of functioning democratic institutions. However, in some Latin American countries, a different scenario of transition to democracy was characteristic a «changeover» variant that included periods of forced change with periods

\footnotetext{
${ }^{21}$ ibid, C. 31-33

${ }^{22}$ Гельман В.Я. Трансформации в России: политический режим и демократическая оппозиция. - М.:МОНФ., 1999. С. 21
} 
of stoppages and reversals, as a result of alternating military or authoritarian regimes);

- a meaningful transit model, the implementation options of which differ in the content of the transition process (so we can speak of a «complex transition» of states, which was characterized by simultaneous economic, political reforms and creation of its independent statehood, that is, carried out a complex transformation. But there were also countries in which development was carried out with the displacement or change of only political system - Spain, Portugal, or changes of purely economic reforms countries of East and Southeast Asia);

- a formal transit model, implementation options differ in the forms of democratic transition: more or less peacefully (such states include those in which the so-called «velvet revolutions» took place - Czech Republic, Bulgaria, Hungary), the transition to democratic rule was the result of intense internal confrontation and struggle by the elites. (Russia), a revolutionary form of transition to democracy (in Latin American countries «... characterized by a sharp liberalization from above, a radical replacement of the political elite, the devastating collapse of the previous regime, democratization from the top and forced socialization. Moreover, such a path of transition is characterized by greater instability, unpredictability and the ability to roll back to a previous, authoritarian system ${ }^{23}$ ).

- a conditioned transit model, implementation options of which differ in the determinants of democratic reform, i.e. the impetus for democratization were external or internal factors, or both.

- a large-scale model of transit, the implementation options of which vary in the scope of citizen involvement in the democratic process (one can observe a mass transition involving large sections of the population, an elitist transition and an intergroup that is under the influence of competition and struggle of several political groups).

- a model of institutional preconditions, the implementation options of which differ in the presence of institutional preconditions of democratization processes in the countries (within this model it is possible to state the initial transition to democracy, which was typical for states that did not have experience of the existence of classical democratic institutions, the secondary transition to democracy, which envisaged the presence in the historical past of democratic and liberal institutions and the aborted transition characterized by the existence of previously certain elements of

${ }^{23}$ Гельман В.Я. Как выйти из неопределенности. Pro et Contra. 1998. Т. 3. № 3. С. 25. 
democratic topics but which were destroyed during the formation of antidemocratic regimes).

Thus, it can be concluded that the separation of models of the transition to democracy is proved by the fact that the transition to democracy in different states is, to a certain extent, conditional, since it is not possible to adjust «unambiguously» the political transformation of the states of one region or even a single country into a framework of strictly defined typological scheme. This will go against the very dialectical process of democratic transit. In the context of the above, we can agree with the opinion of G.I. Weinstein, who emphasizing the importance of analyzing current processes of political transformation in terms of the growth of typological diversity of modern democracy, points out that there are some considerations to be made: «Firstly, the considerable complexity of developing the categorical definitions necessary to describe the typological diversity of democracies should be noted. Secondly, it is necessary to note the essential analytical difficulties of the organic combination of qualitative evaluation of a «new democracy» with its meaningful characteristic» ${ }^{24}$.

\section{CONCLUSIONS}

A comprehensive analysis of the theoretical foundations of the study of the transition to democracy has led to the following conclusions:

«Transit» is to be understood as a transition that develops in a broken pattern, a process that does not always have a positive dynamic and does not always end with the consolidation of democratic institutions and procedures.

It has been established that the development of democracy requires not only some experience of democratic traditions, but also a previous, at least not extensive experience of liberalism, even in monarchical or authoritarian form. It turns out that liberalism is a common basis for different types of democratic system of state and society. Thus, it can be stated that for all models of political transit the process of liberalization of the whole system of public relations is of great importance.

It is determined that the process of political transit includes five main components: initial prerequisites; starting point of reference; goal; the transit process itself and the transit summary. The nature of each of these parameters determines, after all, the specificities of political transit in a particular transitional society.

${ }^{24}$ Вайнштайн Г.И. Российский транзит в контексте глобальной демократизации. Международная экономика и международные отномения. 2000. № 10. С. 81. 
The analysis of classical models of political transit (D. Rostow, L. Diamond, F. Schmitter and G. O'Donnell, S. Huntington) allowed us to consider this process in different focuses. Composing a single process of progressing from a totalitarian state to a liberal democracy, the diagrams of the transit model reflect the diversity of the parties to this process and make it possible to say that one of the main essential characteristics that determines the specifics of political transit is the significant uncertainty of its procedures and results. And the high level of uncertainty of political transit causes a considerable variability in the ways out of this uncertainty at the end of transit.

\section{SUMMARY}

The article provides a comprehensive analysis of the theoretical background of the research of the transition to democracy, which provides for the study of the political transit phenomenon as an object of scientific research and a comparative analysis of models of the transition to democracy process.

The essence of the concept of «political transit» is revealed and its main constituent elements are distinguished. It is established that political transit should be understood not only as a linear, one-dimensional process, but also as a three-dimensional process.

It has been shown that, on a time scale, liberalism and democratization represent two phases of the overall process. Therefore, they are interdependent, and their consistency suggests that without prior liberalization, there can be no deep democratization of a transit society and democracy cannot be rooted in it.

The essence of the concept of «political transit model» is determined and classical models of political transit are analyzed (D. Rostow, L. Diamond, F. Schmitter and G. O'Donnell, S. Huntington). It is established that the transition to democracy in different states is, to a certain extent, conditional, since it is impossible to «adjust» unambiguously the political transformation of the states of one region or even of a single state within a strictly defined scheme.

\section{REFERENCES}

1. Бабкіна О.В. Передумови переходу до демократії: ризики транзитивного суспільства. Науковий часопис НПУ імені М. П. Драгоманова. Серія 22. Політичні науки та методика викладання сочіально-політичних дисииплін. 2015. Вип. 17. С. 3-11. URL: 
http://enpuir.npu.edu.ua/bitstream/123456789/22598/1/Nchnpu_022_2015_1 7_3.pdf

2. Вайнштайн Г.И. Российский транзит в контексте глобальной демократизации. Международная экономика и международные отношения. 2000. № 10. С. 78-89.

3. Гельман В.Я. Как выйти из неопределенности. Pro et Contra. 1998. Т. 3. № 3. С. 21-39.

4. Гельман В.Я. Постсоветские политические трансформации (Наброски к теории). Полис. 2001. № 1. С. 15-29.

5. Гельман В.Я. Трансформации в России: политический режим и демократическая оппозиция. - М.:МОНФ., 1999. 240 с.

6. Карл Т., Шмиттер Ф. Пути перехода от авторитаризма к демократии в Латинской Америке, Южной и Восточной Европе. Международный журнал соииальных наук. 1994. № 1. С. 29-46.

7. Лукин А.В. Переходной период в России: демократизация и либеральные реформы. Полис. 1999. №2. С.134-154.

8. Мельвиль А.Ю. Опыт теоретико-методологического синтеза структурного и процедурного подходов к демократическим транзитам. Полис. 1998. № 2. С. 6-37. URL: http://www.politnauka.org/ library/dem/melvil.php

9. Новейший политологический словарь / Д. Погорелый, В. Фесенко, К. Филиппов. Росто-на Дону. 2009. 318 с.

10. О’Доннелл Г. Делегативная демократия. Предель власти. 1994. № 2/3. С. 5-15.

11. О’Доннелл Г. Делегитивная демократия. Век XX и мир. 1994. №7. C.189-195 URL: http://old.russ.ru/antolog/predely/2-3/dem01.htm

12. Пшеворский А. Демократия и рынок. Политические и экономические реформы в Восточной Европе и Латинской Америке. / Пер. с англ. под ред.проф. Бажанова В.А.-М.:РОССПЭН.-1999.-320 с. C. 222-225.

13. Растоу Д. Переходы к демократии: попытка динамической модели.// Полис. 1996. № 5. С. 5-15. URL: http://read.virmk.ru/R/ Rastou.htm

14. Современный словарь иностранных слов: около 20000 слов. СПб. Дуэт. Комета. 1994. 752 с.

15. Харитонова О.Г. Генезис демократии (Попытка реконструкции логики транзитологических моделей). Полис. 1996. № 5. C. 70-78.

16. Хинтба И.Р. Три этапа эволюции транзитологии: на пути к четвертому? Вестник РУДН, серия Политология 2008 № 2. С. 20-34. 
17. Шмиттер Ф. Процесс демократического транзита и консолидации демократии. Полис. 1999. № 3. С. 30-33.

18. Campbell A., Converse P., Miller W., Stokes D.. The American Voter. N.Y. 1960.573 p.

19. Huntington S. The Third Wave: Democratization in the Late Twentieth Century.-Norman and London: University of Oklahoma Press., $1991.366 \mathrm{p}$.

20. Stepan A. Democratizing Brasil? Problems of Tranzition and Consolidation. N.Y. - Oxford; Oxford University Press, 1989404 p.

\section{Information about the author:}

Myloserdna I. M.,

$\mathrm{PhD}$ in Political Sciences, Associate Professor, Associate Professor at the Department of Political Theories of the National University «Odessa Law Academy» 2, Academichna str., Odesa, 65009, Ukriane 
DOI https://doi.org/10.36059/978-966-397-158-2/103-118

\section{DEMOCATIC CHANGES AND A HYBRID REGIME: A THEORETICAL ANALYSIS}

\section{Dziubenko Yu. M.}

\section{INTRODUCTION}

Modern political processes are characterized by democratic transformations in most countries of the world, which in turn may be accompanied by certain problems. Particularly noteworthy is the problem of threats to democracy and the possibility of a hybrid regime. This problem has become more acute for our country when it comes to the possibility of a return of the political regime in Ukraine to authoritarianism. First of all, it is caused by a significant gap between the purpose, tasks and opportunities of reforming society, its democratization. Implementation and intensification of these threats will facilitate the transition from democratic transformation to reverse transit. Ukraine's political development after the recent events shows that considerable danger to the democratic path of development remains for our country even in the conditions of formally democratic and legitimate institutions.

The need to investigate the threats to democracy and the phenomenon of hybrid regimes is especially important in today's globalized environment, as democratic transit facilitates the country's place and role in the world community and will enable Ukraine to democratize further the society and build a European developed state.

\section{Hybrid political regime: a theoretical analysis}

Thus, among the most famous attempts to investigate the phenomenon of transitional forms of political regimes, we can distinguish the works of such foreign scientists as L. Diamond, G. O'Donnell, M. Ottawa, F. Zachary, T. Carothers, S. Levitsky and L. Wei, A. Shadler, F. Schmitter and others.

Therefore, the main task of this section is the theoretical analysis of the concept of hybrid mode. The hybrid political regime is separated into a separate category, based on the fact that with the existing features of the democratic regime in certain political systems there are still «defects» that characterize the political regime as a hybrid one. Based on this position, it is appropriate to consider the political regime with the term «democracy with 
adjectives $\gg{ }^{1}$ and the current regime is authoritarian, but characterized by the existence of separate democratic institutions, which distinguishes it from the classical forms of authoritarianism. It is not difficult to notice that under both positions the political regime is considered as «mixed», integrating both democratic and authoritarian characteristics. Let's trace the formation and evolution of these two traditions in modern political science.

Domestic scientific literature has been dominated by the view that Gorbachev's perestroika and its consequences should be clearly attributed to the democratization process. Initially, these processes were also considered abroad in the context of democratization ${ }^{2}$.

J.-F. Gage highlights the distinctive features of a hybrid political regime that allow it to be separated into a separate concept. In particular, the author identifies conceptual obstacles in the study of hybrid regimes - recurrence (hybrid regimes worldwide - the predominant form of political regimes), and this tendency is associated with the destruction of the bipolar system of international relations. Since that period, the ratio of the number of states with features of hybrid regimes has hardly changed in comparison with democracies and autocracies ${ }^{3}$ ), sustainability (only recently have studies begun to emerge that highlight the problems of stability and the dynamics of mixed political regimes). Thus, in the period from 1989 to 2007, L. Morlino analyzed the continuity and variability of political regimes. The author concluded that «at least 26 of these can be classified as «stable mixed regimes», i.e., which have been "partially free» for 15 years or longer, and 9 cases as «less continuous and mixed modes», which have existed 10 years without changes; however, of the 45 cases of mixed political regimes during this period, only 7 have carried out or transited democracy and 3 to authoritarianism» ${ }^{4}$ ), regional specifics $-\mathrm{N}$. Brown and K. Kauffman point out that one of the main problems facing researchers of democratic transitional processes is the possibility of separating the «extended transience» from stable political transition.

According to the opinion of A. Remizov, current theories explaining the causes and origins of mixed regimes are more suited to African and Eurasian countries (countries where mixed regimes emerged after the 1990s), and the

1 Collier D., Levitsky S. Democracy with Adjectives: Conceptual Innovation in Comparative Research. World Politics. 1997. Vol. 49. № 3. P. 430-451.

${ }^{2}$ O'Donnel G., Schmitter P. Transitions from authoritarian rule: prospects for democracy.. Baltimore, 1986. 208 p. transit

${ }^{3}$ Analytical briefs. Freedom House. URL: https://freedomhouse.org/report-types/nations-

${ }^{4}$ Ремізов А. Гібридний політичний режим: деякі проблеми концептуалізації. Освіта регіону. 2012. № 3. URL: http://social-science.com.ua/article/848. 
aim of this conception is according to J.-F. Gage, unreasonably, because it is in these regions that there are the most stable «mixed» forms of the regime. In addition, when we talk about mixed regimes created in the post-Soviet space, they are the most unstable, more often than not, changing the trajectory of their development (and, in most cases, not turning toward democracy) $»^{5}$, problems of typology, for example, one country can absorb several types of mixed political regime. In particular, the researchers identified the types of political regime that combined the features of the mixed one. For example, A. Scheedler classified Malaysian political regime as «electoral authoritarianism», L. Morlin as «quasi-democracy», M. Ottawa - «semi-authoritarianism», L. Wei and S. Levitsky as «rivals». On the basis of the above-mentioned meaningful opinion, I consider the opinion of a German scholar, M. Bogar, who in his writings investigated the consequences of the political transformations of the Third Wave and noted, the fact that the presence of numerous definitions of subtypes of democracy and authoritarianism, the absence of common criteria and features that would clearly identify the features of a «mixed» political regime are fundamental to the study of empirical issues ${ }^{6}$.

It should be noted that V. Merkel and A. Croissant can be considered as the first of the scientists to develop a holistic theory and methodological approach to analysis in the phenomenon of mixed political regimes.

The authors introduced the concept of «defective democracy» into scientific circulation. They understand it as a system of domination in which the possibility of access to power is regulated by a powerful and existing universal «electoral regime» (free, secret, equal, and universal elections), but at the same time, there are no other guarantees of basic political and public rights and freedoms, and the horizontal power, control and effectiveness of the democratically legitimate power are severely limited ${ }^{7}$. Particular attention is paid by V. Merkel and A. Croissant to the fact that in defective democracies informal rules (clientelism, personalism, corruption, or cartels, and actors that emerge beyond constitutional boundaries), limit the algorithm for the functionalization of formal, democratically legitimate legitimate factors. They violate the functional codes of formal institutions, deform or

${ }^{5}$ Ремізов А. Гібридний політичний режим: деякі проблеми концептуалізації. Освіта регіону. 2012. № 3. URL: http://social-science.com.ua/article/848

${ }^{6}$ Gagne J.-F. Against Tide? Are Hybrid Regimes more than Sand Castles?. URL: http://papers.ssrn.com/ sol3/papers.cfm?abstract id=1642387.

7 Ремізов А. Гібридний політичний режим: деякі проблеми концептуалізації. Освіта регіону. 2012. № 3. URL: http://social-science.com.ua/article/848. . Brown N., Kauffman C. Introduction. Dynamics of Democratization: Dictatorship, Development, and Diffusion. Johns Hopkins University Press, 2011. P. 1-15. 
replace them as meaningful procedures and decision-making practices. «As a result, at the level of decision-making, democracy functions in accordance with unlawful informal institutions and rules that run counter to the principles of legal democracy» ${ }^{8}$.

V. Merkel cites five criteria that define «defective» democracy: elections, political freedoms, civil rights, horizontal accountability and effects beyond the right to govern'. Accordingly, V. Merkel identifies four subtypes of «defective democracy»: 1) «exclusionary democracy» - which is characterized by all five criteria distinguished by the authors, namely: violation of suffrage by race, ethnicity, gender, polity, gender, sex or gender; 2) «illiberal democracy» - a character that is eroded by the absence of clear boundaries between the executive and the legislative branches, and the judiciary does not, in turn, restrict the first two; 3) »delegative democracy»the legislature and the judiciary exercise limited control over the executive branch, while the constitution is almost not respected by the government in its actions; 4) »guardian democracy» - characterizes the existence of socalled «veto groups» (for example, military movements, international actors), which deprive democratically elected political representatives of the peoples of the political community in access ${ }^{10}$.

Although V. Merkel pays attention to the interconnectedness and importance of every aspect of liberal democracy, the elective indicator of performance is still a function of primus inter pares between "partial regimes». Therefore, first, the emphasis is placed on popular sovereignty as the basis of democracy, secondly, a baseline and criterion is defined for distinguishing democracies from autocracies - countries with no real choices are considered autocritical and are not included in the typology of their democracies.

At the same time, J. Muller and S.-E. Skaaning criticizes some of the propositions of V. Merkel's theory, namely, how to distinguish defective democracies from autocracies, because in their empirical work, researchers have based on the section ad hoc), and not in the dynamics of these regime changes; the correspondence between the "partial regimes» and the subtypes was not perfect, as only four subtypes and defective democracies were constructed as a result of the identification of the five «partial regimes»; the construction of one of the subtypes, namely «exclusionary democracy», does

${ }^{8}$ Ремізов А. Гібридний політичний режим: деякі проблеми концептуалізації. Освіта регіону. 2012. № 3. URL: http://social-science.com.ua/article/848

${ }^{9}$ Меркель В., Круассан А. Формальные и неформальные институты в дефектных демократиях (II). Полис. 2002. № 2. С. 20-30.

${ }_{10}$ Меркель В., Круассан А. Формальные и неформальные институты в дефектных демократиях (I). Полис. 2002. № 1. С. 6-17 
not meet the basic definition of defective democracy as a system and domination in which access to power is governed by its «meaningful» regime; some subcomponents are combined with more than one «partial regime», such as the right to political participation and an independent judiciary $^{11}$.

Also, another point of criticism, but already from another Western researcher - M. Bohaard - is the statement that, that for V. Merkel and A. Croissant there is only one major indicator - democracy, and no other factor is considered - authoritarianism. The German researcher proposes to integrate these two concepts - the defective democracy and the electoral authoritarianism (which is the same «reduced» type of authoritarianism) into one, «two-rooted», for the sake of their variegated regimes ${ }^{12}$. In our opinion, you can agree with M. Bogaards's proposal. Indeed, since any real political regime is composed of many components, the likelihood of combining these components in such combinations when the elements of democratic institutions and processes are combined, explicitly or implicitly, within a single country with certain authoritarian elements. Moreover, the social tradition or habit of the population may even legitimize some authoritarian manifestations of a formally democratic political regime, such as, for example, under General De Gaulle's presidency in France. One can argue about the sources of authoritarian tendencies in the last years of his presidency, but there is undoubtedly the presence in this regime of just such a combination of defective democracy and electoral authoritarianism, as stated by M. Bogaards in his criticism of V. Merkel and A. Croissant.

In this context, a binary typology of the mode offered by the Finnish researcher M. Wiegel is of merit to our attention. Taking the two most important and, according to the scientist, fundamental ideas of democracy the principles of «electoralism» and «constitutionalism» ${ }^{13}$.

All these attributes form a sort of «checklist» for classifying political regimes, following or «comparing» the availability of particular attributes, M. Wiegel identifies four main types of political regimes: authorial, electoral, autocratic, constitutional, oligarchic, and democratic. An

${ }^{11}$ Меркель В., Круассан А. Формальные и неформальные институты в дефектных демократиях (II). Полис. 2002. № 2. С. 23.

${ }^{12}$ Merkel W. Embedded and Defective Democracies. Democratization. 2004. - Vol. 11. Issue 5. P. 33-58

13 . Ремізов А. Гібридний політичний режим: деякі проблеми концептуалізації. Освіта регіону. 2012. № 3. URL: http://social-science.com.ua/article/848. 
analogous «checklist» of Finnish scientists was also built to distinguish mixed political regimes in the model ${ }^{14}$.

Among these, M. Wiegel included «electoral,» «limited,» and «constitutional» democracies. According to the opinion of the researcher, such a two-dimensional typology permits significant comparisons of political regimes and their qualitative and ethical characteristics to be significantly improved from the analytical point of view, since, unlike the one or more, more or less ${ }^{15}$.

Interesting is the variant of typology of the non-critical regimes, proposed by the Danish scientists I. Muller and S.-E. Scaaning.

As a basis for their typology, researchers have taken the following three attributes of a democratic regime: the electoral kernel (free elections) described by J. Schumpeter, the concept of political rights developed by R. Dahl (voting rights, assembly, organizations), and the rule of law, which was justified as a necessary condition of democracy in his writings by G. O'Donnell. Moreover, the researchers emphasize that the well-known Schumper minimalism definition of democracy as a means of gaining power by competing for the electoral votes is more minimal in fact than generally accepted. J. Schumpet's definition is based on general nature of elections (which in this case are «exclusive» - «exclusive elections»), but not at all in their free and deliberate nature (such elections are «inclusive» - «inclusive elections») ${ }^{16}$.

F. Schmitter and G. O'Donnell put forward the concept of «mixed» political regimes and their varieties, which these scholars proposed to call such neologisms, such as dictatorship and democracy ${ }^{17}$. So did S. Huntington, who, analyzing the first results of political transformations in the post-Soviet countries, noted, that a common trend in the development of «third wave democracies» is to turn them into something different from the fullness of democratic regimes. According to him: «We are witnessing the emergence of an increasing number of countries that are somewhere between Denmark and China on the scale of «democracy - not democracy».

${ }^{14}$ Wigell M. Mapping «Hybrid Regimes»: Regime Types and Concepts in Comparative Politics. Democratization. 2008. Vol. 15. №. 2. P. 230-250

${ }^{15}$ Muller J., Skaaning S.-E. Beyond Radial Delusion: Conceptualizing and Measuring Democracy and Non-democracy. International Political Science Review. 2010. Vol. 31. №. 3. P. 261-283.

${ }^{16}$ Bogaards M. How to classify hybrid regimes? Defective democracy and electoral authoritarianism. Democratization. 2009. Vol. 16. Issue 2. P. 399-423

${ }^{17}$ O’Donnell G., Schmitter P. Defining Some Concepts (and Exposing Some Assumptions). Transitions from Authoritarian Rule. Prospects for Democracy / ed. by G. O'Donnell, Ph. C. Schmitter, L. Whitehead. Baltimore, 1986. Vol. 4. P. 9-13 
The essence of the phenomenon of the political regime has forced scholars to return to the question of definition. The first, minimal definition, formulated by J. Schumpeter and subsequently adopted by S. Huntington and other scholars, is based on electoral competitiveness as the essence of those democracies. These conceptions of minimalist democracy, which L. Diamond defines as «electoral democracies,» acknowledge the need for a set of civil liberties that are necessary for competitiveness and participation. At the same time, they do not pay attention to the basic freedoms anticipated and do not seek to include them in the list of valid democracy criteria.

L. Diamond points out that the peculiarity of post-Soviet society is the intermediate position, which does not allow it to be correlated with either liberal democracy or electoral democracy. To understand the dynamics of regime change and the process of democracy development in the context of the «third wave», in which the Ukrainian transformation process takes place, an American scientist considers it necessary to allow the existence of a third category of regimes that do not correlate even with minimalist democracy, but at the same time defines as «pseudodemocracy». These regimes may meet the high demands of constitutional characteristics of «electoral democracy»; they are legally operated by opposition parties; however, they are deprived of such essential democratic qualities as the existence of a field for relatively electoral rivalry capable of leading to the removal from power of the ruling party. L. Daimon believes that many post-Soviet countries, such as Russia or Kazakhstan, in which quasi-institutionalized systems of power were formed, serve as examples of such «pseudo-democracies» ${ }^{18}$.

Thus, in analyzing and post-Soviet political regimes, L. Diamond recommends using a typology, which uses three classifiers. This typology presupposes an account of the evolutionary character of the democracy and should capture intermediate stages within the process. "Pseudodemocracy» is a regime that has made minimal progress from authoritarianism. A more advanced stage is «electoral democracy». Finally, the consolidation of democracy, which means the expansion of mass civil liberties and the assimilation of democratic values at the level of political culture and population, permits the democratization of the regime.

In political science, one of the most widely deployed and substantiated concepts of the essence of the transitional regime can be recognized as the theory of «mixed mode», which was proposed by L.F. Shevtsov ${ }^{19}$.

${ }^{18}$ Levitsky S., Way L. The Rise of Competitive Authoritarianism. Journal of Democracy. 2002. Vol. 13. № 2. P. 51-65.

${ }^{19}$ Шевцова Л. Ф. Режим Бориса Ельцина. М. : Московский Центр Карнеги, 1999. 535 с. 
Investigating the problems of transitional regimes typology, L.F. Shevtsova notes that the experience of some countries of the postSoviet space does not allow them to be fully attributed to the classification already developed. Among them, the most similar to the post-Soviet regimes are the types of «delegated democracy» and «bureaucratic-authoritarian states» developed by G. O'Donnell on the example of Latin American countries $^{20}$. However, the author notes, along with a number of similar characteristics, transitional regimes in countries of the former USSR that have special features.

The concept of «competitive authoritarianism» has received considerable recognition among scholars and was developed by American political logos S. Levitsky and L. Weyem, who were among the first to call for the use of different categories from the category of «democracies with adjectives» to the movement towards democracy. In this case, definitions such as «delegative democracy», "semi-democracy», «virtual democracy», «electoral democracy», «illiberal democracy» and many others are misleading as to the true direction, trajectories, which are obviously not moving in the direction of democracy ${ }^{21}$.

Under the conditions of competitive authoritarianism, basic democratic institutions are functioning, but the abuse of power by the opposition entails that the normative functions of these institutions are deformed.

At the same time, competitive authoritarianism is strikingly different from the traditional authoritarian regime. Unlike pure authoritarianism, in the face of competitive authoritarianism, the opposition maintains some spaces of freedom for its activities. If full-scale authoritarianism overtly and brutally crushes the opposition, then under competitive authoritarianism, the government acts more sophisticatedly, limiting its administrative measures through fiscal, judicial, and other oversight services.

\section{Current trends of deformation of democratic regimes}

As the experience of developed countries shows, there are serious problems in democracy, the solution of which is a prerequisite for its effective functioning. J. Bechler calls these problems «distortions of democracies», N. Bobbio - «unfulfilled promises of democracy», F. Schmitter - «threats of democracy», and S. Eisenstadt - «fragility of modern democratic regimes».

\footnotetext{
${ }^{20}$ Шевцова Л. Ф. Режим Бориса Ельцина. М. : Московский Центр Карнеги, 1999. С. 508.

${ }^{21}$ Levitsky S., Way L. The Rise of Competitive Authoritarianism. Journal of Democracy. 2002. Vol. 13. № 2. P. 52.
} 
Many states in South America, Eastern Europe and Asia, according to F. Schmitter, will not be able to establish a form of stable self-government appropriate to their social structures or acceptable to citizens. Democracy never transforms itself into a specific, reliable and generally accepted set of rules $^{22}$. A particular state chooses its type of democracy by resolving dilemmas related to its own history, geostrategic position, natural and human resources. F. Schmitter identifies the internal dilemmas inherent in modern democracy, regardless of place and time of its emergence, and external ones, which call into question the compatibility of new democratic rules and practices with existing social, cultural and economic conditions ${ }^{23}$.

Scientists include internal problems, first of all, oligarchy, selfelimination, «cyclicality in politics», functional autonomy, interdependence of national leaders from other democracies and some autocracies ${ }^{24}$.

External dilemmas are determined by the collective choice between alternative institutional arrangements compatible with existing socioeconomic structures and cultural realities.

According to F. Schmitter, only knowledge of the habits brought up by the experience of democracy in the country, and only the location of actors within the appropriate methods of transition allow to give a correct assessment of the most adequate use of the institutions of power. History shows that not all countries have ever been able to consolidate democracy on the first attempt.

From the point of view of F. Schmitter, there are at least two other options for development in countries that have embarked on the path of democratic transformation: the creation of a hybrid regime that combines elements of autocracy and democracy, which is endowed with the signs of unconsolidated democracy ${ }^{25}$.

In cases where the transition period is initiated and imposed from above, the former rulers try to protect their interests by «grafting» authoritarian practices. In the cases where they carry out liberalization without democratization (that is, when certain individual rights are allowed without citizenship consent), leading to the emergence of a hybrid regime, this form of government is called by F. Schmitter dictablanda. In the same cases when

22 Шмиттер Ф. К. Угрозы и дилеммы демократии. Русский журнал. URL: [http://www.russ.ru/antolog/predely/1/dem2-2.htm.

23 Шмиттер Ф. К. Угрозы и дилеммы демократии. Русский журнал. URL: [http://www.russ.ru/antolog/predely/1/dem2-2.htm.

24 Роберт Міхельс і його «залізний закон олігархії». URL: http://yuriyshveda.com.ua/de/communication/teoria-politichnih-partiy/484-michels.html

25 Шмиттер Ф. К. Угрозы и дилеммы демократии. Русский журнал. URL: [http://www.russ.ru/antolog/predely/1/dem2-2.htm. 
the political elite conducts democratization without liberalization (that is, when elections are held, but in the conditions of guaranteed victory of the ruling party, exclusion of certain socio-political groups from participation in them, or deprivation of elected citizens of real government) neologism «democradura» was proposed.

Both dictablanda and democradura have become quite commonplace as authoritarian rulers seek to introduce democratic mechanisms in their states to make visible the progressive transformations of international forces that require democratization.

Threats to democracy in post-socialist countries have been studied by many researchers. S. Huntington believes that barriers to democratization can be divided into three broad categories: political, cultural and economic ${ }^{26}$.

Klaus Offe reasonably noted that «the legal and representative political system will become adequate and will restore legitimacy only when a degree of autonomous economic development has already been achieved ${ }^{27}$.

The problem is compounded by the fact that the political culture of authoritarian egalitarianism, shared by the majority of the citizens of these countries, does not envisage either a market economy or democracy as reform goals.

Robert Dahl points to inequality as a fundamental problem in all democracies. The perspective of democracy development, in its view, depends on the degree of approach of the demos (people) to the decisionmaking elite. The improvement of citizens, their active participation in the life of society and the state is a prerequisite for the development of democracy. And the higher the level of political participation, the closer the citizens are to the ever-increasing level of demands on the participants in the political process, the closer democracy is to its ideal, which one can and should strive for, but which cannot be achieved ${ }^{28}$.

Democracy threats can also come from both the masses and the elite. Analyzing the behavior of the masses in the context of American democracy, Peter Bahrach wrote: «The widespread commitment of society to the fundamental norms that underpin the democratic process has been regarded by theorists of classical democracy as an integral element of the survival of democracy. ... Today, however, sociologists tend to reject this view. They came to this conclusion not only because of doubts about the commitment of

${ }^{26}$ Хантингтон С. Третья волна. Демократизация в конце XX века / пер. с англ. М.: РОССПЭ, 2003. С. 338.

27 Оффе К. Культурные аспекты консолидации: заметки об особенностях посткоммунистической трансформации. Восточноевропейское обозрение. 1998. № 1. С. 11.

${ }^{28}$ O'Donell G., Schmitter P. Transitions from Authoritarian Rule: Tentative Conclusions about Uncertain Democracies. Baltimore, Md : Johns Hopkins University Press, 1986. 280 p 
«non-elites» to freedom, but also because there is a growing conviction that «non-elites» are mostly inspired by political elites. The empirical conclusion that the behavior of the masses is usually a reaction to the position, proposals and actions of political elites, further confirms the view that the responsibility for maintaining the «rules of the game» rests with the shoulders of the elites, not the people» ${ }^{22}$.

However, while elites more than the masses are committed to the values of democracy, they often abandon those values in times of crisis and resort to repression. The activism of the masses and the repression of the elites are often combined, creating numerous threats to democracy. The activity of the masses, which is manifested in riots, demonstrations, extremism, violence, arouses fear and danger in the elites who respond to restrictions on will and increased security measures. At the same time, dissent is questioned, the press is censored, freedom of speech is restricted, representatives of potential counter-insiders are imprisoned, and police and security forces are being strengthened in the name of «national security» or «law and order».

The elites are convincing themselves that these steps are necessary to preserve liberal democratic values. T. Dai and L. Ziegler point out: «The irony is that by trying to preserve democracy, the elites are turning society into a less democratic one» ${ }^{30}$.

E. Eisenstadt believes that the constitutional-democratic regimes are fraught with fragility and instability, the origins of which are determined not by specific causes that can cause instability in any social structure or political system, but rooted in the ideological and institutional history of modern political institutions, in the cultural and political agenda of today. Israeli political scientist believes that the basis for such allegations is the openness of the political process in constitutional democracies and the tendency to re-evaluate constantly the political sphere. «This openness,» writes Schnitz Eisenstadt, «is the main reason for the fragility of modern democratic regimes, but the paradox is that it ensures the continuity of their existence ${ }^{31}$. The openness of political systems testifies to their ability to adapt to the changing reality, the perception of the necessary changes, which leads, in the words of Eisenstadt, to the formation of the idea of politics as a «game» with zero amount, when winning one side is not equivalent to losing the other.

29 Оффе К. Культурные аспекты консолидации: заметки об особенностях посткоммунистической трансформации. Восточноевропейское обозрение. 1998. № 1. С. 8.

${ }^{30}$ Дай Т. Р., Зиглер Л. Х. Демократия для элиты: Введение в американскую политику. М. : Юрид. лит-ра, 1984. С. 48-49.

31 Эйзенштадт Ш. Н. Парадокс демократических режимов: хрупкость и изменяемость (I). Полис. 2002. № 2. С. 67. 
J. Bechler explains the "deficit of democracy» by inevitably hostile circumstances. First of all, it is an economic cycle that does not remain in a stable state for a long time, which negatively affects the realization of promises coming from the government to the citizens. An even more hostile circumstance for democracy is social stratification. In an ideal democracy, the distribution, according to the majority of researchers, should not be equal, but fair. Everyone receives their share of power, wealth, prestige in accordance with their competence, contribution to common wealth and their merit. The mobility of the individual, both vertical and horizontal, should be high, which should lead to the creation of ever changing, weakly expressed hierarchies.

However, the reality is far from a democratic ideal, which is explained by the benefits that proximity to power brings to the next generation. This leads to the fact that power, prestige and wealth depend to a large extent on the social layer to which this or that individual belongs. As a result, competence, contribution to the common cause, natural gifts and personal merit can be humiliated and deprived of their legal rights by holders of a position inherited and preserved in the face of democratic justice. The resulting social stratification causes protests against inequality in a democratic society.

As noted, J. Bechler distinguishes three types of distortions of democracy - political, ideological and moral ${ }^{32}$. By political distortions, he understands the political market, which means exchange, distribution, and search. Exchanges occur between the private and public spheres. Private interests act as one of the parties to the exchange and offer their votes and assistance to the partner during the election. Their partners are politicians who need votes and the support of citizens for election to the authorities. This is where the conflict with democracy arises. Since democracy is the the desire in the common affairs for the common good, there is a conflict of interest between the private and the public. The distortion of democracy is all the more explicit here, the more actively the private interests are implemented, which entails the opposite process - the suppression of private interests by the public sphere ${ }^{33}$. Distortion is exposed to the activities of politicians who send their activities not for the common good, trying to convince citizens of their interpretation of the common good and authority in the search for the right goal. The bottom line is that the political market legitimizes dishonesty.

${ }^{32}$ Бешлер Ж. Демократия. Аналитический очерк / пер. с фр. М. : изд-во «Памятники исторической мысли» 1994. 208 с.

${ }^{33}$ Бешлер Ж. Демократия. Аналитический очерк / пер. с фр. М. : изд-во «Памятники исторической мысли» 1994. 208 с. 
Ideological distortions arise from the fact that every principle of democracy can be misinterpreted, and any false interpretation can lead to ideological conclusions that are dangerous to democracy if they are put into practice. J. Bechler dwells on the two most common principles. One of them is the sovereignty of the people. People are abstractions. It is a team that is always silent, possessing neither the will nor the capacity to act. To declare that power belongs to the people means to create a real danger of replacement of the people by its representatives who consider themselves legitimate bearers of power. And since the people are silent and decide nothing, then these representatives become holders of unlimited power, which leads to the emergence of autocratic regimes.

Another ideological distortion is the belief that democracy is the rule of the majority. J. Bechler believes that it is certainly valid for the public sphere, and that there are distortions in the sphere of private interests. So, instead of generating middle interests through a regulated market as a result of free trade, people prefer to organize a general meeting at which a majority, whose interests are imposed by others, is revealed by voting. According to the French political scientist, such a procedure is unlawful and illegal in a democratic society; moreover, it allows manipulation by organized groups and is an excuse for the oppression of minorities. Completed to its logical conclusion, the majority rule leads to autocracy ${ }^{34}$.

Moral distortions include all abuses of liberty that are facilitated by the guarantee of public liberties, the separation of public and private spheres and the principle of political legitimacy of all opinions. The scientist focuses on the differences of people in their adaptation to the surrounding living conditions. The strongest, the minority, are able to clearly set goals and strive to achieve them. Most include not the strongest or the weakest, but ordinary people who are able to take care of the problems and be responsible for the results achieved, while the weakest ones, who are also a minority, are unable to solve the problems that arise. They are poorly adapted and do not know how to experience modern individualization on their own and for themselves ${ }^{35}$.

\section{CONCLUSIONS}

Thus, despite these deficits and the distortions of democracy, J. Bechler looks optimistically into the future of democratic development, justifying his optimism that, first, they cannot all exist forever, and second, their gradual filling enhances the stability of democracy. Democratization is stretching over time, which in an unexpected way contributes to stability. Modern

\footnotetext{
${ }^{34}$ Бешлер Ж. Демократия. Аналитический очерк / пер. с фр. М. : изд-во «Памятники исторической мысли» 1994. 208 с.

${ }^{35}$ Бжезинський 3. Великі перетворення. Політична думка. 1994. № 3. С. 5-14.
} 
democratic institutions and practices are capable of peacefully resolving problems between the authorities and society by changing the team in power in a fair, impartial election.

In order for democratic development to become a reality, citizens must have a sufficient stock of patience and optimism, as they are forced to adapt quickly to the new situation and wait long enough for the positive results of reforms.

Despite all the difficulties that democracy has to face on its thorny path, we are living in a democratic era. For a long time, the danger of human life, liberty and happiness came from the absolutism of monarchies, the dogmatism of churches, the terror of dictatorships and totalitarian leaders. Dictators and some totalitarian regimes still exist, but they are becoming increasingly anachronistic in the modern world. There is no longer a decent alternative to democracy, it represents, in the words of American political scientist F. Zacharya, «part of the present» ${ }^{36}$.

Thus, in the twenty-first century, problems of government are likely to be problems within democracy itself. This complicates their decision as they dress in the mantle of legality.

\section{SUMMARY}

It is established that there is no single and comprehensive classification of hybrid regimes among scientists. However, an analysis of the existing attempts at typologizing allows us to distinguish the electorally-autocratic and constitutionally-oligarchic type of hybrid regime. The criteria for distinguishing between types of hybrid regimes include the level of compliance with the principles of «electoralism» and «constitutionalism». The main tendencies of deformation of democratic regimes in emerging countries and sustainable democracies are revealed. These include the socalled «distortions of democracy», "unfulfilled promises of democracy», «threats to democracy» and «the fragility of modern democratic regimes».

\section{REFERENCES}

1. Бешлер Ж. Демократия. Аналитический очерк / пер. с фр. М. : изд-во «Памятники исторической мысли» 1994. 208 с.

2. Бжезинський 3. Великі перетворення. Політична думка. 1994. № 3. С. 5-14.

3. Дай Т. Р., Зиглер Л. Х. Демократия для элиты: Введение в американскую политику. М. : Юрид. лит-ра, 1984. 320 с.

36 Закария Ф. Возникновение нелиберальных демократий. Логос. 2004. № 2 (42). C. $55-70$ 
4. Закария Ф. Возникновение нелиберальных демократий. Логос. 2004. № 2 (42). C. 55-70.

5. Клямкин И. М. Что значит быть демократом сегодня?: логика реформации тоталитаризма (круглый стол). Полис. 1991. № 4. С. 47-51.

6. Меркель В., Круассан А. Формальные и неформальные институты в дефектных демократиях (I). Полис. 2002. № 1. С. 6-17.

7. Меркель В., Круассан А. Формальные и неформальные институты в дефектных демократиях (II). Полис. 2002. № 2. С. 20-30.

8. Оффе К. Культурные аспекты консолидации: заметки об особенностях посткоммунистической трансформации. Восточноевропейское обозрение. 1998. № 1. С. 8-10.

9. Ремізов А. Гібридний політичний режим: деякі проблеми концептуалізації. Освіта регіону. 2012. № 3. URL: http://socialscience.com.ua/article/848.

10. Роберт Міхельс і його «залізний закон олігархії». URL: http://yuriy-shveda.com.ua/de/communication/teoria-politichnih-partiy/484michels.html

11. Хантингтон С. Третья волна. Демократизация в конце XX века / пер. с англ. М.: РОССПЭ, 2003. 368 с.

12. Шевцова Л. Ф. Режим Бориса Ельцина. М. : Московский Центр Карнеги, 1999. 535 с.

13. Шмиттер Ф. К. Угрозы и дилеммы демократии. Русский журнал. URL: [http://www.russ.ru/antolog/predely/1/dem2-2.htm.

14. Эйзенштадт Ш. Н. Парадокс демократических режимов: хрупкость и изменяемость (I). Полис. 2002. № 2. С. 67-82.

15. Analytical briefs. Freedom House. URL: https://freedomhouse.org/ report-types/nations-transit.

16. Bogaards M. How to classify hybrid regimes? Defective democracy and electoral authoritarianism. Democratization. 2009. Vol. 16. Issue 2. P. 399-423.

17. Brown N., Kauffman C. Introduction. Dynamics of Democratization: Dictatorship, Development, and Diffusion. Johns Hopkins University Press, 2011. P. 1-15.

18. Collier D., Levitsky S. Democracy with Adjectives: Conceptual Innovation in Comparative Research. World Politics. 1997. Vol. 49. № 3. P. 430-451.

19. Diamond L. Is Third Wave Over? Journal of Democracy. 1996. Vol.7. № 3. P. 20-37. 
20. Gagne J.-F. Against Tide? Are Hybrid Regimes more than Sand Castles?. URL: http://papers.ssrn.com/ sol3/papers.cfm?abstract id $=1642387$.

21. Levitsky S., Way L. The Rise of Competitive Authoritarianism. Journal of Democracy. 2002. Vol. 13. № 2. P. 51-65.

22. Merkel W. Embedded and Defective Democracies. Democratization. 2004. - Vol. 11. Issue 5. P. 33-58.

23. Muller J., Skaaning S.-E. Beyond Radial Delusion: Conceptualizing and Measuring Democracy and Non-democracy. International Political Science Review. 2010. Vol. 31. №. 3. P. 261-283.

24. O'Donell G., Schmitter P. Transitions from Authoritarian Rule: Tentative Conclusions about Uncertain Democracies. Baltimore, Md : Johns Hopkins University Press, 1986. 280 p.

25. O'Donnell G., Schmitter P. Defining Some Concepts (and Exposing Some Assumptions). Transitions from Authoritarian Rule. Prospects for Democracy / ed. by G. O'Donnell, Ph. C. Schmitter, L. Whitehead. Baltimore, 1986. Vol. 4. P. 9-13.

26. O'Donnel G., Schmitter P. Transitions from authoritarian rule: prospects for democracy.. Baltimore, 1986. $208 \mathrm{p}$.

27. Wigell M. Mapping «Hybrid Regimes»: Regime Types and Concepts in Comparative Politics. Democratization. 2008. Vol. 15. №. 2. P. 230-250.

\section{Information about the author: Dziubenko Yu. M., $\mathrm{PhD}$ in Political Science,} Associate Professor at the Department of Political Theories of the National University «Odesa Law Academy» 2, Academichna str., Odesa, 65009, Ukriane 
DOI https://doi.org/10.36059/978-966-397-158-2/119-134

\section{POLITICAL DIALOGUE - A KEY TOOL FOR PROVIDING DEMOCRATIC TRANSIT}

\section{Pielievin I. Yu.}

\section{INTRODUCTION}

In today's world, where many of the former restrictions are being removed and the field of social interaction is expanding, dialogue (from Greek dialogos - converse, conversation, or exchange of thoughts, negotiations, understanding) is becoming an increasingly popular form of relationship). In the modern sense, dialogue is a certain analogue of public diplomacy as a negotiated procedure with a final agreement. Political dialogue is a path that leads from disputes, differences and conflicts through the stages of joint discussion of problems, convergence of positions and further - to the understanding and cooperation of participants in communication. It is no coincidence that in politics dialogue turns into a norm of civilized cooperation and democratic interaction of the parties, which may differ in terms of views and functional and structural characteristics, but recognize the right to the existence of other, alternative views, opinions, beliefs, values.

As a reasonable alternative to violence, war, terrorism, revolutions, insurrections, riots and other manifestations of political extremism, radicalism, intolerance and intolerancy, dialogue has always occupied and continues to occupy a special place in the processes of democratic transit. In this context, the dialogue in politics should be understood not as a conversation between two or more persons on the subject of political life, but as a certain configuration of interaction, negotiation process and partnership built on the principles of discursive equality between political communication entities seeking to understand and achieving a mutually beneficial result.

Democratization of relations between the state and society, which is an integral part of democratic transit, involves creating an atmosphere of trust and harmony, including through political dialogue between public authorities, citizens and public institutions representing their interests. Dialogue is not just a conversation, but a certain type of social relationship. In the process of dialogue, the participants of communication must not only 
listen and hear each other, but also follow the agreed rules of communication. In this connection, it should be noted that in our country the culture of political dialogue, debate, controversy has not yet received the relevant theoretical knowledge, or the implementation of social and political and administrative practices. Hence, the study of political dialogue in Ukraine is of particular relevance. After all, the formation of a culture of dialogue interaction is the key to the irreversibility of the processes of democratization, the formation of new democratic, legal, social relations between the main actors of the political process.

\section{Political dialogue as a phenomenon of social life and scientific category}

The axiological status of the dialogue is so high that it is rightly on par with such fundamental political values as democracy, freedom, equality and equal rights. From the point of view of contemporary scholars of political discourse, democracy is not so much a set of procedures and their application, but a dialogical interaction between different policy makers the state, parties, NGOs and individuals including. And some of them go further and propose to abandon the vague and meaningless concept of «postmodernism» in favor of characterizing modern times as an «era of multidimensional dialogue», of inclusive and universal dialogue ${ }^{1}$. In this connection, there is a need for optimal disclosure and understanding of the possibilities of political dialogue, as a special form of dialogue, as relations between two or more actors, exchange of opinions, first of all, on sociopolitical and socio-economic topics, search for effective ways of its using.

To achieve this, one should turn to the arsenal of diverse fields of sociohumanitarian knowledge, each of which focuses on particular aspects of dialogue, both as a phenomenon of social being and as a scientific category.

Thus, in the social-philosophical key, such well-known intellectuals as M. Bakhtin, M. Buber, B. Waldelfels, F. Ebner, E. Levinas, G. Marseille, O. Rosenstock-Hussi, F. Rosenzweig and others were engaged in the analysis of public dialogue.

At the beginning of the last century, the philosophy of dialogue offered its own way of acquiring a person its identity, which was lost as a result of the development of industrial society. In this way, dialogue becomes, in fact, a way of reviving spiritual values, a way of returning to eternal You - God (M. Buber, B. Walldelfels, G. Marseille). Famous works of M. Buber «Me and You» ${ }^{2}$ and $\left\langle\right.$ The Problem of Man» ${ }^{3}$ became the first to come up with the

\footnotetext{
${ }^{1}$ Каган М. С. Философия культуры. Санкт-Петербург: Изд-во «Питер», 1996. С. 402-404.

${ }^{2}$ Buber Martin I and Thou. Martino Publishing, 2010. Reprint of 1937. 137 p.
} 
idea of dialogue as a tool to overcome the spiritual crisis of European civilization. Thus, in the paper «The Problem of Man,» M. Buber identifies two major factors that deepened the anthropological crisis of the twentieth century. It is the destruction of social connections and the loss of spirituality. The result of their actualization was the alienation of man both from himself and from the world he created. In order to resolve this contradiction, the philosopher abandons the traditional individualistic and collectivist approaches and proposes to turn to the dialog model «man with man». At the same time, the essence of the Bouber dialogue is realized not in the subjects (participants) of the dialogue, and not in the world where they are near things - objects, but only in the dimension that is accessible only to them and exists between (desswishen) them.

Other representatives of the philosophy of dialogue attach decisive importance not to dialogue relations as such, but to their individual refraction. Thus, the concept of M. Bakhtin's dialogue contains the idea of the enormous importance of «I». The philosopher places the very personality in the center of the universe, and therefore the dialogue takes place not in the interpersonal space (desswishen by M. Buber), but in the space of the categories «I» and «You» ${ }^{4}$.

Creative achievements of M. Buber, M. Bakhtin and others. provided impetus for further development of various concepts of dialogue and interpersonal communication (C. Axelrod, A. Akhiezer, V. Bibler, P. Vermes, S. Gurevich, M. L. Diamond, M. Kagan, G. Pomerantz, M. Friedman and etc.). Thus, in the context of the processes of archaizing the post-modern society, O. Akhiezer explores the problem of social dialogue. The central ideas of his concept are «inversion» and «mediation» as the focus of public consciousness on the past (outdated, archaic, traditional) and future (new, avant-garde, innovative), respectively. The main source of social tension, according to A. Akhiezer, is the clash of archaization (anti-mediation) and the progress that comes before anything between cultural values and lifestyles that differ in their focus on static or dynamics. According to the scientist, in such a situation, the only cardinal means of overcoming social disorganization is the development of dialogue as a system of certain relationships and (sub)culture through the formation of $132 \mathrm{c}$.

${ }^{3}$ Бубер М. Проблема человека; пер. с нем. Киев: «Ника-Центр», «Вист-С», 1998.

${ }^{4}$ Бахтин М. Эстетика словесного творчества. Москва: Искусство, 1979. 424 с. 
appropriate institutions and the development in various diverse social groups of the ability to make joint decisions ${ }^{5}$.

The problematization of the dialogue relations «I - the Other», carried out in classical phenomenology, is elaborated in the concept of «Alien» by B. Waldelfels. He proposes to remove the traditional dichotomy of «His own / Alien» to establish a new «responsive» type of rationality. Its basic concepts («alien», «failure of intentionality», «challenge - answer») are considered as the basic characteristics of modern discourse ${ }^{6}$.

$\mathrm{V}$. Bibler discusses the dialogical nature of human consciousness in his writings on the dialogue of cultures ${ }^{7}$.

In general, the philosophy of dialogue has shown the importance for the existence of a person of dialogical relations as such.

Further analysis of the phenomenon of social dialogue at the level of methodology of social processes cognition, interaction and exchange of information and theory of polyparadigmatic development of science was carried out in the fundamental works of such authors as M. Weber, G.-G. Gadamer, G. Lasswell, J. Mill, J. Ritter, et al.

Thus, M. Weber explores the phenomenon of social dialogue as a kind of social action. The latter is one of the simplest elements of the social system, a unit of sociological analysis. Action, according to Weber, is human behavior that gives the subject some meaning (motivation). A social scientist called an action that, in its sense, puts into it an active individual or group, focused on the corresponding behavior of other accomplices of interaction, that is, on certain expectations. Therefore, according to Weber, social action must have at least two necessary features: first, the subjective motivation of an individual or group, to be aware; second, focused on the past, present or future behavior of others (friends, work colleagues, etc.) ${ }^{8}$. Social actions are caused by dissatisfaction, that is, a mismatch between what a person needs and what he or she needs. Dissatisfaction is manifested in various forms: hunger, material discomfort, anxiety, creative anxiety. The level of dissatisfaction will change if the goal is achieved. The goal is the expected consequence of meeting the need. Formation of a personal goal aimed at

\footnotetext{
5 Ахиезер А. Архаизация как категория общественных наук. Журнал социологии и соииальной антропологии. 2001. Т. 4. № 1.С. 89-100.

${ }^{6}$ Waldenfels B. Phenomenology of the Alien: Basic Concepts (Studies in Phenomenology and Existential Philosophy). Evanston: Northwestern University Press, 2011. 104 p.

${ }^{7}$ Библер В. Мышление как творчество (Введение в логику мысленного диалога). Москва: Политиздат, $1975.400 \mathrm{c}$.

${ }^{8}$ Вебер М. Соціологія. Загально історичні аналізи. Політика; пер. 3 нім. Київ: Основи. 1998. C. 322-346.
} 
meeting one's own needs, taking into account the possible reaction of the environment, is the motive of social action.

Usually purposeful actions are the most likely to solve problems effectively. However, the likelihood of realization of one or another type of motivation for social action depends both on the characteristics of the individual, his culture, education, intellectual capabilities, and on the type of society, socio-cultural environment, the mass distribution of certain types of motivations.

Each society is dominated by one of these several varieties of interaction, and it defines the relations of domination, subordination, as well as the nature of the society itself. The dominance of traditional and affective interactions forms a traditional society, purposeful and value-rational industrial. In order to understand the functioning of society, it is necessary to consider more closely its interaction with individuals, the interaction of individuals and groups themselves.

In particular, G.-G. Gadamer brings the issues of public dialogue into the field of hermeneutical analysis. For him, dialogue is both communication (conversation) and a way to relate the test to the person reading the text. Consequently, the ontological status of the dialogue is refracted in the plane of speech. Hence, the goal of genuine dialogue, at both personal and social levels, is to understand and reach agreement. However, to understand for G.-G. Gadamer is to understand the case itself, not the opinions of others about the case. In this way, the dialogue creates a community that closely connects the rich number of participants with diverse, often opposite positions, into a single communicative space.

\section{The role of dialog communication in the functioning of political systems}

Dialogical issues are actively studied within the framework of the theory of integrative understanding of social structure of society, which is considered in the works of J. Alexander, E. Arato, Y. Habermas, E. Gellner, E. Giddens, J. Kin, J. Kogen, N. Luman, J. McLean, T. Parsons, N. Smelser, A. Toynbee, O. Toffler, T. de Chardin and others.

Thus, N. Luhmann defines power as a means of communication that «differs from other means of communication in that its code requires partners, that is, on both sides of the communicative attitude, to reduce complexity by actions rather than by excitement» ${ }^{9}$. The regulator of such interaction of actors in civil society space should be dialogue, which leads to

\footnotetext{
9 Луман Н. Власть; пер. с нем. Москва: Праксис, 2001. С. 34.
} 
the emergence of generally accepted norms and principles of joint practical interaction.

This view is also reflected in the works of E. Giddens, who emphasized that $\ll \ldots$ in social systems it is vital to recognize the degree of interdependence, because the relations of interdependence are always and everywhere the relations of power. Power in social systems can be interpreted as containing a relationship of reproducible autonomy and dependence in social interaction $\gg{ }^{10}$.

The eminent American researcher, the founder of the systematic approach to the study of society, T. Parsons emphasized the important constructive role of dialog communication in the formation and development of human activity in the functioning of social systems. According to him, «the complexity of systems of human activity is impossible without relatively stable symbolic systems, and the latter are created and function only through communication processes» ${ }^{11}$.

As a philosophical principle that affirms openness in relations at the individual and social levels and serves as a dialogue. It is the dialogue that allows the individual to be «socially responsible», «able to see» (P. Teillard de Chardin), «to accept challenges» (A. Toynbee).

According to $\mathrm{Y}$. Habermas's theory of communicative action, if instrumental action is aimed at success, then communicative action is about mutual understanding of the subjects of communication, their consensus. At the same time, their agreement on the situation and the expected consequences is based on conviction, not coercion. It involves the coordination of the actors`efforts, which are aimed at understanding.

The analysis of social and psychological aspects of dialogue interaction depending on the forms of political order is presented in the works of F. Borkenau, V. Bocheliuk, R. Dahl, A. Inkeles, R. Leventhal, J. Talmon, E. Fromm, S. Huntington, T. Khomulenko etc.

However, the dialogue aspect has not yet been sufficiently elaborated, taking into account the relevance of the democratic model of public policy to the specific parameters of the dialogue.

In spite of the rather thorough developments in the field of the study of dialogue as a form of social communication, represented by social and philosophical knowledge, in the newest theories of management (V. Isaacs, S. Dietz, O. Zaitsev, L. Ellinor, J. Gerard, N. London, W. Lawrence,

\footnotetext{
${ }^{10}$ Гідденс Е. Соціологія; пер. $з$ англ. Київ: Основи, 1999. С. 122.

${ }^{11}$ Парсонс Т. Понятие общества: компоненты и их взаимоотношения. Американская соииологическая мысль: Тексты. Под. ред. В. И. Добренькова. Москва: Изд. Международного ун-та Бизнеса и Управления, 1996. С. 498.
} 
L. Lynn, B. Pearson, J. Simpson, K. Skelcher, S. Heinrich, S. Hill, L. Hoss, $\mathrm{K}$. Hood, etc.) only indicates the need to find new forms and means of interaction of power with the public.

For example, according to the opinion of the American researcher $\mathrm{W}$. Isaacs, the purpose of dialogue is not so much solving problems as «dissolving» them. The dialogue is defined by V. Isaacs in the line of hermeneutics, as a process of communication, purposefully directed to the search, study and formation of understanding. Dialogue creates a space and a way to study and explore the essence of the issue through the analysis of collective and individual ideas, beliefs and feelings. The dialogue is not about changing people's beliefs or behavior, but about informing and teaching them. Dialogue provides opportunities for its participants to listen and be heard; to talk to others and talk respectfully; to develop or deepen mutual understanding; to learn about other thoughts, to talk about your own point of view; to build relationships in a positive way.

For L.K. Hos, the main component of dialogue is the reduction of the level of conflict, as dialogue is a «practice of mediation in competing and conflicting discourses» ${ }^{12}$. L. Ellinor and J. Gerard describe dialogue as a fundamental process of communication that fosters a high level of trust and openness. There are no differences in the dialogue process. Dialogue, from the perspective of these authors, is used to understand the nature of an existing problem.

According to S. Landon, the purpose of the dialogue is not to solve or eliminate the problem, but to «explore the most promising areas for action.» In his view, the dialogue focuses on common interests, not differences ${ }^{13}$.

S. Dietz and J. Simpson believe that dialogue, since the second half of the twentieth century, has become a major feature of society and humanity's hope that it will ever be able to withstand the global challenges of today. Based on the ideas of Y. Habermas and G.-G. Gadamer they has developed a «politically responsive» communication theory (PRCT) of constructionist dialogue, which recognizes the particular importance of political situationalism and understanding of the «other» ${ }^{14}$. For S. Dietz and J. Simpson, the dialogue is organically linked to communication on socially

12 Hawes L. C. The dialogics of conversation: Power, control, and vulnerability. Communication Theory. 1999. № 9. P. 229.

13 London S. The Power of Dialogue. Scott London: website URL: http://www.scottlondon.com/articles/ondialogue.html.

${ }^{14}$ Deetz S., Simpson G. Critical Organizational Dialogue: Open Formation and the Demand of «Otherness». University of Colorado Boulder: website. URL: http://www.colorado.edu/Communication/comm4600880/Deetz. 
significant public issues between stakeholders. According to the researchers, such a dialogue is synonymous with public discussion.

The dialogic theory of public relations is well developed overseas, especially in North America. Along with J. Grunig, a scientist whose name is associated with the emergence of this model, other foreign authors have worked on the same problem and continue to work on it. In the late 1990s and early 2000s, a number of scientists recorded the so-called «dialogical turn» in public relations (Dialogical Turn of Public Relation). Extremely fruitful contribution to the study of the dialog model of public relations was made by K. Bozan, R. Burkart, R. Lipper, R. Pearson and others.

In our opinion, not only the study, but also the implementation of this model in the processes of social power, are extremely relevant for Ukraine. After all, social practice and increase of civic activity of the population testify that traditional socio-cultural models of monologic communication of the state and civil society require modernization, development of feedback mechanisms and institutionalization of new mechanisms of communication of the authorities and society and technologies of communication with the public in the format of symmetrical dialogue.

All this introduces the issue of improving political dialogue in the subject range of current problems of domestic political science. Today, for policy theory, dialogue is a channel for connecting citizens, social communities, civil society institutions, and businesses with public agencies and government. And since democratization implies that subjective and subjective relationships take place between the institutions of state power and civil society, and are not devoid of conflict and competitiveness, since they involve diversity of interests, awareness of the format of dialogue is very important. In this connection there is a need to explore not only the traditional forms of dialogic interaction in politics, but also its new manifestations.

\section{Dialogue of the state and civil society - the communicative basis of democratic transformations in a post-totalitarian society}

The political dialogue of a democratic format is based on a dialogue, parity and contractual basis, based on general democratic principles, the use of which reflects the general level of development of the state and civil society. On this basis, the main purpose of political dialogue is to involve society in the process of public policy implementation through regulation of socio-economic and socio-political development.

The necessary components of the dialogue structure are: a) the actors, b) the subject of the discussion, c) the space of action, d) the time of the 
action. Each of these elements has its own «dialogical» features. In addition, the dialogue also has other characteristics, which include: a) the position of the actors of the dialogue; b) high energy of the field of interaction (which presupposes expressiveness and effectiveness of positions and parties); c) deep conditionality of the dialogue with the degree of historical development of individuals, society, etc. In this context, the dialogue is, first and foremost, a special type of communication that involves the active interaction of equal actors.

Dialogue is a social phenomenon, because it is first and foremost a contact of people. Dialogue in communication is characterized by the perception of the opponent as comfortable, at least not as uncomfortable, indicating that there is at least a minimal element of unity between the participants of the dialogue. The content of human communication is the achievement of some consensus necessary for any social community to coexist with others. Features of social dialogue, unlike its individualpersonal and group varieties, are more conditioned not so much by personal characteristics, gender, professional or ethnic structure of the population, but by the objective conditions of human existence. That is why public dialogue is of great importance in ensuring the social stability of the society as a whole.

Therefore, public dialogue is the most important functional characteristic of society. It is realized in all forms of interpersonal relationships and interactions, both explicit and implicit. It is, first and foremost, a dialogue between civil society and the state. The first delegates its powers to the second, alienating from the constant dispatch of power functions. It can be said that the degree of civilization of the society is largely determined by the extent to which the dialogue between civil society and the state is open and equal.

It is important that the dialogue between the state and civil society, being one of the varieties of political dialogue, at the same time often acts as social (in the broad sense) or civil (public) dialogue. This dialogue involves not only institutional subjects, actors or policy agents (state, political parties, political leaders, political technologists, etc.) but also ordinary citizens, public associations and non-profit organizations of the third sector.

This tendency is quite clear in the practice of interaction between the authorities and civil society institutions in the developed democracies of the West and some countries of the East. Today, in the face of changing confrontation between the state and civil society, distrust and alertness towards civil society institutions, the need for cooperation and interaction is 
gradually coming to fruition, the broadening of the public sphere, the institutionalization of civil dialogue and public engagement in civil society.

In this connection, it should be noted that in political theory and practice, these processes were often accompanied by criticism of the liberal model of democracy, where the central moment for a long time remained electoral procedures and the formation of a representative system of exercise and functioning of power, which led to alienation of broad sections of society from real participation of society politics, reduced voter activity, loss of legitimacy of the government and its decisions. The solution was found to combine the values of electoral democracy with the mechanisms and procedures of participatory democracy and deliberative democracy of discourse. In fact, the latter significantly expanded and institutionalized numerous dialogues and practices. The mechanisms and technologies of public relations (PR) in the field of political and public administration have been supplemented by GR-technologies, where the public (third sector) and business (second sector) have already initiated interaction, communication and dialogue with the state, government and authorities (the first sector).

At the end of XX - beginning of XXI century, many normative ideas of participatory democracy and deliberative dialogic discourse, which previously seemed utopian, as well as many effective mechanisms and technologies of symmetrical and equal PR and GR - communication in the mode of dialogue, were further developed in the communicative practices of «open government», «e-state» and «e-democracy». Today, relational networking communities with horizontal dialogues and relationships are actively shaping the new networked civil society. Such a society is beyond the control and not subject to the state. But at the same time, it does not oppose it, and will continue to play an increasingly prominent and essential role in the real political process, both within the state itself and internationally.

It is the new interactive media operating on-line in the sphere of Internet space that have become a real alternative to the unified information policy of autocratic regimes, which build communication with the society on the principle of domination of the interests of the state, on the information monopoly, which is reproduced in the form of power, on advocacy and total control over the information agenda, on manipulative technologies of informing citizens and forming public opinion. Moreover, the absence of a full-fledged dialogue between the authorities and the society, effective mechanisms of feedback from the authorities and the public, deprive the government of responsiveness, make it inert, routine, incapable of timely response to the transformation of public opinion and political sentiment in society. 
As the current political situation shows, in some countries, communication technologies that were actively used in the mid-twentieth century during the Cold War have not fully exhausted their militaristic potential and continue to be used in the latest political communications. Former forms and genres of political communication demanded by the authorities themselves still prefer not dialogue, but monologue, not interaction, but influence, not argumentation, but manipulation, not deliberation, but orders, commands or instructions.

And there is some explanation for this. After all, politics is still in some cases the most competitive field of activity, dominated not by the desire for cooperation, agreement, compromise, consensus and dialogue, but the desire to win at any cost. At the same time, the intention to hold power is viewed not so much as competition, contest, rivalry, but as irreconcilable struggle, hostility or even war. In this paradigm of understanding politics and political power, dialogue is pushed out of the political process and viewed as a manifestation of political romanticism has nothing to do with «real politics» and genuine political interests.

In fact, politics involves both competition and consent, which can be implemented in the form of various types of public dialogue, which are a reasonable alternative to violence, bloodshed and civil strife. Thus, it is the real, not the simulative, dialogue that can transform any, even the most acute, socio-political conflict from which all parties can benefit and enjoy. So, the dialogue of the conflict type (rallies, protests, polemics, debates, discussions, etc.) will be replaced by a cooperative type dialogue (negotiations, consultations, hearings, examinations, public control, etc.).

The process of public dialogue implies the availability of tools and mechanisms to enable government agencies and authorities to be more fully informed about the opinions of ordinary citizens. Social dialogue is one of the types of political dialogue aimed at preventing social divisions and deepening mutual understanding, improving interaction and building constructive cooperation between different strata of society. Such dialogue is a continuous, ongoing and improved communication process, involving both representatives of all levels of government and ordinary citizens, both employers and employees. The multilateral and inclusive nature of public dialogue is the objective necessity of creating in the society and the state an atmosphere of trust, openness, readiness for inclusion in an institutionalized system of information exchange.

In general, dialogue in society can be defined as an intersubjective way of publicly expressing socio-political views, opinions, judgments and evaluations of the subjects of communication, whereby understanding and agreement between the participants in the discourse are achieved. Ideally, all stakeholders involved in the topic or issue under discussion should be participants. These are: 1) those on whom decision-making on the problem 
depends; 2) those who can block these decisions; 3) those whose life will be affected by the decisions made on the issue under discussion.

Political dialogue is an important factor in the dynamics of sociopolitical development of society and the modernization of society. At the same time, it is very important that the actors of the dialogue are representative (would have the authority for appropriate communication) and autonomous (financially, organizationally and politically independent both from the state, from business, as well as from foreign sponsors).

An open and full-fledged political dialogue is characterized by the activity of discussion and expression of different points of view with elements of discussion by all its participants. And the peculiarity of the political dialogue is that the act of speaking by one of the participants implies the act of listening and understanding when it is obligatory to change the roles in this interpersonal interaction.

However, it should always be remembered that dialogue or negotiations between government and the public is a tool, but not a strategy for achieving change. Dialogue in itself is not a panacea and its outcome depends on the extent to which its subjects are relevant to their mission, how capable they are, and ready for a full rather than simulating dialogue. It is through dialogue, not ultimatum, or other means of manipulative pseudo-borrowing.

Obviously, the transition from the traditional «vertical» influence to the interaction-dialogue in the relations between the authorities and the public is a key condition for the implementation of a democratic project in transition societies. This involves uniting the creative efforts of government officials and civil society as direct actors of political dialogue.

\section{CONCLUSIONS}

To sum up all of the above, let's try to make some generalizations.

1. Dialogue is an extremely complex, multifaceted and multi-aspect phenomenon. It is no accident that attention is drawn to the dialogue of such political science-related sciences as philosophy, sociology, theory of public administration, cultural studies, psychology, history, logic, anthropology, as well as a number of other disciplines: communication science, management, PR (public relations), pedagogy, philology, rhetoric, religious studies, journalism and more. Philosophers view dialogue in terms of its epistemological, ontological, heuristic, cognitive and methodological aspects. Sociologists' dialogical discourse is interested in the problems of understanding, interpretation and social construction of reality. Dialogue in terms of sociology is the socio-cultural basis of society and the most important means of communication and resolution of social conflicts in society. For cultural scientists, dialogue is of particular value as a way of tolerant coexistence and peaceful interaction between different cultures («dialogue of cultures»), as well as a form of creativity and self-expression 
in the field of art. Psychologists are trying to break into the psychology of interpersonal dialogic interaction. Educators see in the dialogue a humanistic model and method of upbringing and learning. PR and advertising experts view dialogue as the most productive way of establishing mutually beneficial communication with society. For the theory of government, dialogue is a channel for establishing links between public organizations, civil society institutions, and business with government agencies and government.

2. From the standpoint of political theory, the axiological status of the dialogue is so high that it is rightly on par with such fundamental political values as democracy, freedom, equality and equal rights. The prerequisites for political dialogue are political pluralism, political tolerance and communicative competence, the ability to listen, understand and to meet each other for peace, stability and overcoming differences.

3. Dialogue interaction is a form of social interaction and is a form of social dialogue. The latter is the most important functional characteristic of modern society and is implemented in all forms of interpersonal relationships and interactions, both explicit and implicit. As a form of social dialogue, political dialogue is, first and foremost, a dialogue between civil society and the state, which results in the transfer to civil society of some of its powers of the state and control over their implementation. The degree of civilization of a society is largely determined by the extent to which the dialogue between civil society and the state is open and equal.

4. The basic principles of political dialogue as a form of social interaction are the following: mutual assistance with complete independence of the subjects; efficiency in relation to responsibility; transparency and openness in information sharing and planning. Political dialogue is based on a dialogue, parity and contractual basis, based on common democratic principles, the use of which reflects the overall level of development of the state and civil society. In this case, the main purpose of political dialogue is to involve society in the process of regulating socio-economic and sociopolitical development.

5. In Ukraine, the study of political dialogue is of particular importance in connection with the formation of new democratic, legal, social relations between the main social groups, where the leading role belongs to civil society institutions, to achieving their equal interaction with public authorities. Today, in Ukraine, previous monologic relations in the sphere of political interaction as communication between the state and civil society, as a dialogic interaction between the authorities and the individual, are being substantially transformed into dialogical. Former administrative-command, monologue-propaganda methods of managing the society are no longer working, and dialogue is a common practice not only within the civil society itself (in the virtual space of Internet communications), but also in the sphere 
of communication of public institutes with the authorities at the central, regional and local levels. In the process of dialogue interaction, there is symbolic interpenetration and even mediated by the dialogic unity of the fusion of the subjects of communication, that is, hermeneutic - cognitive understanding and mutual understanding of each other by the subjects of dialogue.

6. One of the key conditions for deepening the processes of democratization and establishing a model of democratic governance in Ukraine both at the national and local levels is the legitimate, dynamic and voluntary cooperation of the state with civil society. The main mechanism of implementation of this model is the extension of the communicative (dialogical) space. It is the constant dialogue that ensures mutual understanding and constructive cooperation of the state with civil society. The active role of all parties involved in communication and the willingness, desire and ability of the parties to interact, based on the principles of mutual responsibility on the one hand, and the desire to solve problems independently, play a major role in the process of establishing a dialogue between the authorities and the public. Important in this is both the strengthening of public initiative institutions and the role of nongovernmental organizations, civil society as a whole.

7. The most effective practices for establishing a constructive dialogue between society and the government are contained in the arsenal of participatory democracy, which, in combination with the mechanisms of representative democracy, will be able to ensure that the interests of citizens and social groups are maximally taken into account when making socially significant decisions and public participation in society. Only under such conditions it is possible to guarantee the irreversibility of democratic transformations that Ukraine took the path in 1991.

\section{SUMMARY}

The article is defined the specificity of dialogue as a phenomenon of social existence on the basis of theoretical and methodological approaches within the framework of philosophy, sociology, psychology, philology, cultural studies, theory of public administration, political science and a number of other disciplines. Specific characteristics of dialog communication in the functioning of political systems are given. It is proved that dialogue interaction is a form of social interaction and is a form of social dialogue. The latter is the most important functional characteristic of modern society and is implemented in all forms of interpersonal relationships and interactions, both explicit and implicit. As a form of social dialogue, political dialogue is, first and foremost, a dialogue between civil society and the state, which results in the transfer to civil society of some of its powers of the state and control over their implementation. The main purpose of political 
dialogue is to involve society in the process of regulating socio-economic and socio-political development.

It is determined that one of the key conditions for deepening the processes of democratization and establishing a model of democratic governance in Ukraine both at the national and local levels is the legitimate, dynamic and voluntary cooperation of the state with civil society. The main mechanism of implementation of this model is the extension of the communicative (dialogical) space. The most effective practices for establishing a constructive dialogue between society and government are contained in the arsenal of party-democracy, which, through its combination with mechanisms of representative democracy, will ensure that the interests of citizens and social groups are maximally taken into account when making socially significant decisions and public participation in society.

\section{REFERENCES}

1. Buber Martin I and Thou. Martino Publishing, 2010. Reprint of 1937. $137 \mathrm{p}$.

2. Deetz S., Simpson G. Critical Organizational Dialogue: Open Formation and the Demand of «Otherness». University of Colorado Boulder: website.

URL:

http://www.colorado.edu/Communication/comm4600880/Deetz.

3. Ellinor L., Gerard G. Dialogue: Rediscover the Transforming Power of Conversation. London: Wiley, 1988. 416 p.

4. Habermas Jü. Theorie des kommunikativen Handelnsю Bd. 1: Handlungsrationalität und gesellschaftliche Rationalisierung; Bd. 2: Zur Kritik der funktionalistischen Vernunft. Frankfurt am Main, 1981. $1216 \mathrm{~s}$.

5. Hawes L. C. The dialogics of conversation: Power, control, and vulnerability. Communication Theory. 1999. № 9. P. 229-264.

6. Isaacs W. Dialogue and the Art of Thinking Together: A Pioneering Approach to Communicating in Business and in Life. Bantam Doubleday Dell Publishing Group, 1999. 428 p.

7. London S. The Power of Dialogue. Scott London: website URL: http://www.scottlondon.com/articles/ondialogue.html.

8. Waldenfels B. Phenomenology of the Alien: Basic Concepts (Studies in Phenomenology and Existential Philosophy). Evanston: Northwestern University Press, 2011. 104 p.

9. Ахиезер А. Архаизация как категория общественных наук. Журнал сочиологии и сочиальной антропологии. 2001. Т. 4. № 1. C. $89-100$.

10. Бахтин М. Эстетика словесного творчества. Москва: Искусство, 1979. 424 с.

11. Библер В. Мышление как творчество (Введение в логику мысленного диалога). Москва: Политиздат, 1975. 400 с. 
12. Бубер М. Проблема человека; пер. с нем. Киев: «НикаЦентр», «Вист-С», 1998. 132 с.

13. Вебер М. Соціологія. Загально історичні аналізи. Політика; пер. 3 нім. Київ: Основи. 1998. 534 с.

14. Гадамер Х.-Г. Истина и метод. Основы философской герменевтики; пер. с нем. Москва: Прогресс, 1988.704 с.

15. Гідденс Е. Соціологія; пер. $з$ англ. Київ: Основи, 1999. 726 с.

16. Каган М. С. Философия культуры. Санкт-Петербург: Изд-во «Питер», 1996. 415 с.

17. Луман Н. Власть; пер. с нем. Москва: Праксис, 2001. 256 с.

18. Парсонс Т. Понятие общества: компоненты и их взаимоотношения. Американская соииологическая мысль: Тексты. Под. ред. В. И. Добренькова. Москва: Изд. Международного ун-та Бизнеса и Управления, 1996. С. 494-526.

19. Тейар де Шарден П. Феномен человека; пер. с фран. Москва: ООО Изд-во АКТ, 2002. 553 с.

20. Тойнби А. Постижение истории: Сборник; пер. с англ. Москва: Прогресс. Культура, 1996. 607 с.

Pielievin I. Yu., $\mathrm{PhD}$ in History, Assistant Professor, Department of Political Science, Odessa National Polytechnic University 1, Shevchenko av., Odessa, 65044, Ukraine 
DOI https://doi.org/10.36059/978-966-397-158-2/135-152

\section{POLITICAL RISKS AS A SOCIO-POLITICAL PHENOMENON IN THE ASPECT OF MODERNIZATION OF THE POLITICAL PROCESS}

\section{Pekhnyk A. V.}

\section{INTRODUCTION}

Changes in the modern world, the growth of elements of unpredictability in public life, the uncertainty of the nature of political processes, the need to find the means to take into account the factors of uncertainty in political activities determine the feasibility of investigating the mechanism of the relationship of risk and technology to the actual implementation of the political process. The crisis in Ukraine reduces the level of governance, makes it impossible to solve economic and social problems in a timely manner, the authorities lose the confidence of citizens and threaten democracy. The authorities must not only be able to lead the society out of the crisis, but also to prevent new crises from occurring. In order to be aware of the likelihood of a crisis, risks, including political risks, must be considered. Globalization processes are accompanied by risk in all spheres of activity due to the uncertainty, controversy and ambiguity of the nature of these processes. Significant political risk factors, along with the stated restriction on the sovereignty of the nation-state, are risks in the activities of decision-making governments, as well as actualization of environmental hazards, rising energy prices, international trends in capital movements, global drug trade, rising terrorism, etc. In order to influence the risk factors, it is necessary to study them carefully.

Risk research is an attempt to adapt to the globalized world. The need to study policy and political risks is linked to the need to analyze, predict and model the development of political processes in order to preserve statehood and pursue their own interests within a democracy.

\section{Risk as an object of study in various sciences}

Risk is the object of study in various sciences. Most of the economic works today study the risk associated with investment, insurance, financial activities, risk in business, in the banking sector, and at risk is the risk of incurring losses. Less relevant research in philosophy, law practice, 
sociology, psychology, which consider risk as a form of manifestation of human behavior. It should be noted that risk in politics can include not only the political component, but also a wide range of economic, organizational, social, psychological, manipulative and other actions, it is wider in the content of the category «political risk».

The need to study policy risks is linked to the need to analyze, predict and model the development of political processes in order to preserve statehood and pursue their own interests. And if philosophy, synergetics pose a problem, then the study of risk aims to solve it, to help adapt to the situation of uncertainty.

M. Levchenko defines that «the structure of political risk research includes four stages: a comprehensive analysis of the field of research; systematic assessment of political risk factors; political risk forecasting; political risk management.» ${ }^{1}$ And we have to agree with that.

Until the XVII century, there was no general concept for risk. At the time, it was only about fate or rock or fortune. A new era that changed the understanding of destiny, ideals and goals also brought a new awareness of risk as a key factor in human activity and as one of the conditions for success. The origin of the word «risk» comes from the Portuguese language and translates as «rock», which, in turn, penetrated into Portuguese from the Greek language, which meant «stream». The term «risk» from the Latin «risicare» means «to decide.» In theory and practice, the concept of risk is multilateral and ambiguous.

In most cases, the term «risk» (political, social) is defined as the likelihood of unwanted events. The category «political risk» has appeared in the lexicon of foreign multinationals and banks, which have suffered significant financial losses in foreign markets, especially in countries with so-called transition economies. Risk has been studied to assess the social and political situation in countries of possible investment. Political risk was understood as the risks to which companies in other countries were exposed, assessed as a deterioration of economic activity of entities in foreign markets as a result of the influence of political factors: conflicts, instability, the rise of nationalism, fundamentalism. In all cases, we are talking about the negative impact of political causes on the economy. This understanding of political risk has become entrenched in modern political science. However, it should be noted that this position is very narrow and reflects only the

Левченко М. О. Політичний ризик як один із факторів впливу зовнішньоекономічної діяльності машинобудівного підприємства. Економічний вісник Донбасу. 2011. № 2(24). C. 53-57. URL: http://www.evd-journal.org/download/2011/ 2011-2/Ek_visnyk_2_2011-53-57.pdf. 
utilitarian interests and goals of the investor country. Depending on the purpose, risk assessment and approaches to risk factors may also change.

The modern state is increasingly faced with the need to analyze risks in various aspects not only of foreign but also of domestic policy. Emerging markets and democratization processes increase political instability. It is not only about revolutions, coups, changes in government and exchange rate, but also risks that do not pose a threat to the investor country, on the contrary, are a real threat to national security and political stability, which is caused by internal political processes. Powerful political decisions at the national level do not necessarily affect the activities of foreign companies, dramatically or substantially affecting domestic political processes in economic, political, social and other spheres.

Risks in political activity in the structure of riskology are one of the main research objects, because many kinds of economic, psychological, social and other risks are largely related to the political stability and legitimacy of the authorities. When studying the implementation of a political process, risk theory deals with the problems of its manifestation in political activity, the risks associated with the functioning of the political system, the analysis of the degree of admissibility, social acceptability and justification, the choice of optimal, appropriate technologies for policy implementation. Development of methods that allow to analyze effectively, identify, evaluate risks in political activity, to take it into account in the technologies of political process implementation - is a necessity dictated by the needs of today. But despite this, the problem of risk in the political process is not sufficiently developed for Ukrainian science.

In modern foreign and domestic literature there is no single, commonly accepted definition of the category «risk». Depending on the area of scientific interests of the authors, various phenomena, states and processes are called «risk». But everyone recognizes that risk is a meaningful, multifaceted and unpredictable phenomenon in various processes, including political.

Political risk issues have been the subject of debate in science since the late 1960s. However, attempts to take into account the political risk posed by the actions of individual statesmen or governments were made in the 19th century. So, the Rothschild banker organized a system of information about political events that he received news about them a few days before the government.

In scientific circulation, the term «risk» was introduced by the American researcher F.Knight. In his view, uncertainty and risk should be distinguished. «Risk or likelihood complements to some extent the 
theoretical analysis of empirical data research $»^{2}$. A large number of authors use the term «risk» as a synonym for uncertainty. In this case, they are talking about deciding in uncertainty instead of deciding in risk. Naturally, there are appropriate logical reasons for this, because risk is one of the means of overcoming uncertainty and arises only in a situation of uncertainty about the possibility of achieving the intended result.

In the field of politics, in particular, this means that in a situation of uncertainty, a political entity does not have complete information about alternatives to solving a problem, their usefulness and he is not aware of the likelihood of a political situation, events that are influenced by a large number of external factors. It is in this situation that his actions become risky. That is, the concept of «risk» is used to refer to an objective uncertainty that is subject to regulation, whereas the concept of «uncertainty» is necessary to denote an irrationality given.

There are different approaches in the political, legal, and philosophical literature to understanding the relation between objective and subjective in the phenomenon of «risk». First, there is a widespread view that risk is a phenomenon that has only objective meaning because it is determined by human-independent conditions. Risk is a form of describing real uncertainty, its expression in quantitative and qualitative characteristics, and corresponds to some objective regularities of social life. This is the objectivity of the risk that exists regardless of whether or not political subjects are aware of it, whether they consider it or not in their activities.

In general, the concept of "political risk» appeared in the lexicon of American corporations in 1959 after F. Castro came to power in Cuba. Political risk can be found in virtually any publication dedicated to the problems of modern society and its political development. However, it should be noted that there is very little research on this topic, which indicates, first and foremost, the lack of analytics affecting this particular area of concern. Accordingly, its lack affects the effectiveness of political decisions. This means that there is an objective socio-political order for research on political risks: the creation of methods for their selection and evaluation, as well as the development of methods for its accounting and reduction in the organization of political activity.

This area was most developed in the USA. It is there, since the late 1950 s, that various concepts and theories have been intensively developed to underpin political risk issues. This is, first of all, the theory of modernization, the ideas of popular capitalism, the welfare state, neoliberalism, the theory of globalization, etc.

\footnotetext{
${ }^{2}$ Найт Ф. Понятие риска и неопределенности. THESIS. 1994. № 5. С. 22.
} 
Also, the impetus for the development of this direction in political science was the emergence of a systematic approach, cybernetics, mathematics, etc. Their widespread use as a methodological basis for sociopolitical sciences in the $1950 \mathrm{~s}$ and $1960 \mathrm{~s}$ led to an interdisciplinary synthesis. The result is a rapid development of new theories and applied political studies, one of which in the US is the concept of political risk.

The development of US political risk research has undergone several stages, each reflecting the specifics of the internal and external political situation and, to some extent, the achievement of applied management and political science. There are several stages in the development of this theory: the «phenomenon of growth» (1950-60), «flourishing» (1970s - early 1980s), «difficult» (1980s).

At the turn of the 1950s and 1960s, the classic concept of political risk was born. It has traditionally been associated with the events in Cuba in 1959, when, after Fidel Castro came to power, the ownership of foreign companies was nationalized. Then, in the 1960s, a number of fundamental works emerged, focusing on the issues of political risk assessment and management. At the same time, political risk means, first and foremost, the damage suffered by a corporation as a result of adverse political events: nationalization, confiscation, political and natural unrest. The purpose of those years' research was to provide guidance on protecting the interests of American TNCs and their financial resources. Most of these papers address the political risk analysis of corporations at the international level. Therefore, at this stage, numerous theories of transnational corporations, organization theory, practical experience of companies regarding their interaction with the external environment, as well as the theory of international business have played a significant role in political risk research.

At the same time, the need for political risk analysis was exacerbated by the fact that in the conditions of the struggle of two ideologized systems: the capitalist and the socialist, a political factor was of great importance. Understanding this situation - one of the reasons for the organization, special departments of political risk analysis as an independent structural unit in Western TNCs since the late 60's - early 70's of the 20th century. The expansion of their activities in «third world» countries encountered various trends that had an adverse effect on business: nationalization of property, expropriation, coups, civil and partisan wars, other forms of political instability. The practical needs of business and government circles in the West in managing capital, in the face of political instability and developing theoretical risk studies have led to the development of an entire 
market infrastructure of services to serve the needs of business in risk management.

During the 70-80s of the 20th century, the focus of research attention was broadened in applied political risk analysis. This phase is linked to the 1979 Islamic Revolution in Iran, which forced Western political and academic circles to reconsider conceptual and applied approaches to securing Western representation in the Third World. During this period, which lasted until the mid-1980s, interest in the issue of political risks peaked, but eventually faded away.

The third stage comes in the so-called «difficult»1980s. At this time, the search for reasons for the failure of the application of the concept of political risk in the analysis of the development of different political and economic systems, and attempts to rethink these concepts. Analysts and politicians are convinced that military-political methods, including diversionary measures against the leadership of various states, traditionally used by the US government to protect the economic interests of their corporations, do not always produce the expected results and should be used as a secondary factor in achieving political goals.

In other words, it has become necessary to develop effective tools to anticipate negative events in the political sphere and evaluate their consequences. This has led to the creation of a worldwide network of specialized centers, both commercial and non-commercial, for the analysis and forecasting of political risk. In Western countries, there are more than 500 such organizations, the vast majority of which are in the United States. These organizations study various aspects of political risk and make proposals for political risk management.

\section{Problems of political risk at the level of applied political science}

The problems of political risk that are required in assessing its level of consideration of the complex diversity of different political and social factors relate to applied political science. However, political risk management at the present-day level requires an appropriate scientific base, the development of which plays a fundamental role in basic research in the field of political science, in particular, works that develop contemporary ideas about political and social processes and their patterns. This is a study of applied political science, which studies the issues of stabilizing the internal political situation and must take into account the laws that are important in assessing political risk.

In foreign practice, issues of applied political science are quite often addressed in the literature devoted to strategic planning and management. 
Important provisions on the nature of political risk are contained in works on applied political science by authors such as D. Abell, V. Asher and V. Overholg, I. Ansoff, G. Steiner and many others. Among the Soviet authors who considered political risk, one might call A.P. Algin, who believes that exploring the place and role of risk in the restructuring process is one of the aspects of meeting the requirements of increasing the attention of the social sciences to practice, their addressing the real goals and needs that are relevant in life. Publications in this field have also started to appear in our country, some of which are listed in the sources used.

Classical science defines risk as an objective, manageable, weighted phenomenon. Because of this, the risks are the dangers of technology and natural disasters. C.Star and his followers (R.R. Appuluri, R. Beit, M. Waterstone, W. Werner, M. Douglas, J. Edems, W. Covello, L. Cool, M.J. Cooper, L. Lave, V. Leiss, V. Lawrence, A. Moissy, P. Ricci, J.V. Rodricks, V. Rove, W. Hauptmannns, J. Hendmer, P. Stern, H. Feinberg, K. Chosiolko, M. .Subik et al.) raised the problem of the mismatch of risk perception by scientific, industrial and governmental structures on the one hand, and the public on the other. In their view, the only problem here is people's response to risk, which is generally not rational. The main discussions within this paradigm are around the concept of «pleasant» («acceptable») risk.

Socially oriented scholars (R. Grove-White, S. Jasanoff, M. Douglas, J. Edems, R. Catherine, D. Mayo, R. Hollander, D. Nelkin, M.T. Thompson, S. Rainer, K. Hood) seek to demystify technical risk analysis, enhance the role of social protection and enhance the value of political culture.

Psychology considers risk as a subjective phenomenon that implies choice in alternative situations (B. Bremer, A. Vyks, K. Hood, D. Jones, H. Joe, N. Kogan, M. Volesh, S. Krimsky, X. Margolis, R. Trimpop, F. Jatz). Separate risk areas in psychology are the theory of prospect («prospectus») of A. Tversky and D. Kaneman, who refer to the prospectus as «bet» as a «game» with possible results, and psychometric theory of decision-making by P. Slovik and Y. Kozeletsky, according to by which people tend to behave rationally. Here, risk is seen as an element of the decision-making and implementation process that is usually associated with measuring the likelihood of an error or the success of a given choice in a multi-alternative situation. The risk of making individual decisions is motivated, appropriate. The risk of group decisions is more objective, but destructive processes in group dynamics often reduce the level of group interaction, which increases the possibility of unreasonable risk. Such a 
feature is accepted to be explained by the phenomenon of group thinking, which I. Janis drew attention to.

In jurisprudence, risk is seen as an event that creates disorder, harms, and allows one to identify who is the victim and who is the offender (F. Ewald, K. Coleman, J. Simon).

Economic theory explores risk in the context of decision making. The problem of business riskiness was raised by the classics of modern economic theory such as A. Smith, D. Ricardo, M. Weber, J. Schumpeter, J.M. Keynes, J. Galbright, K. Arrow, F. Knight, etc. In modern western economic science, two theories of risk have been formulated: classical (risk as the probability of damages and loss from the chosen decision and strategy of activity (J. Mill, I. Senor)) and neoclassical (risk is the probability of deviation from the set goals (A. Marshall, A. Pigu, J. Keynes, K. Arrow, F. Knight).

In considering the place of political risk problems in the system of scientific knowledge, the socio-philosophical analysis of this concept deserves special attention. This is important to provide the necessary depth of understanding of the content of the political risk concept and to develop modern perceptions of it as a particular scientific category. For example, in the works of A.P. Algin the idea is presented that this concept reflects the common features inherent in the categories of human cognition of the environment. Therefore, when considering the concepts of risk and, accordingly, political risk from a methodological point of view, it is advisable to analyze the nature and internal contradictions of the properties of these concepts related to the characteristics of activities, including political. This approach to the concept of risk opens new opportunities for theoretical research, allows to introduce into the field of philosophical knowledge those aspects and nuances of social reality, human activity, which are difficult to detect, but which create the preconditions for deepening the content of already known categories. From this perspective, we can analyze the relationship of this concept with different philosophical categories. It is noteworthy, for example, the relationship of the concept of political risk to such categories as necessity, chance, uncertainty, objectivity and subjectivity.

It should be noted that in modern Ukrainian science, the problems of risk, riskology are most developed in the economic aspect, namely in the areas of consideration of investment risks, mechanisms of risk management, entrepreneurial risks, economic activity, etc. A lot of thorough research is devoted to this layer. These are the works of such scientists as M. Damaskin, 

A. Gryschenko,
M. Stepur,
O. Taran,
L. Bondarenko,
O. Kolot,
N. Skopenko, V. Kryvoshein.

As V. Gorbatenko correctly determines, «the main areas of political riskology, which is gradually becoming the domain of applied political science, are: analysis and assessment of non-commercial risks for international business; decision making in conditions of socio-political uncertainty; venture (risky) political technology. Research on political risks is needed first and foremost by the decision-making bodies in the country or region, as well as by banks, firms, organizations planning to invest their capital in certain countries or regions. $\rangle^{3}$.

Another aspect I would like to highlight is the presence of an appropriate level of uncertainty, which is one of the important features and a risk environment. However, such uncertainty must be objectively existing, that is, due to the unpredictability of the actions of socio-political actors, the spontaneity of phenomena that occur in nature and society, the limited resources in decision-making and implementation, as well as the lack of knowledge of the surrounding reality. Uncertainty acts as a reflection on multivariate, ambiguous social and applied processes. It is organically inherent in the whole process of social development, because any stage of it always contains the possibility of change, including qualitative ones, caused by internal and external factors, which are not taken into account due to limited knowledge or subjective mistakes of persons, decision makers. This means the objective impossibility of accurately predicting socio-political events.

Sources of uncertainty in society are diverse. Common reasons that contribute to the creation of uncertainty and subsequently risk situations are usually indicative of limited resources (material, financial and other) in making and implementing decisions, incompleteness or distortion of available information, inability to unambiguously disclose the content of phenomena or processes. Uncertainty is generated by the existence of many differences in socio-political attitudes, ideals, assessments, stereotypes of behavior and values of people in relation to various social relations, as well as under the influence of the results of scientific and technological progress on the socio-economic, political and spiritual conditions of social development. That is, uncertainty is associated with the ability to capture the occurrence of a variety of situations and consequences in a subject's activity.

There are two main types of risk that need to be considered in order to understand what is happening in the world today. The first kind can be

${ }^{3}$ Горбатенко В. П. Політичні ризики: від теорії до практики. Суспільно-політичні процеси. 2016. Вип. 2. С. 55-69. URL: http://nbuv.gov.ua/UJRN/pubpolpr_2016_2_4. 
conditionally called external risk. External risk is a risk that is beyond ourselves: it is related to unchanging traditions or laws of nature. Another variation is the risk associated with our knowledge of the outside world. The category of man-made risk includes situations that humankind has virtually never encountered before in history, for example, most of the environmental risks associated with global warming. Increasing globalization has a direct impact on them.

From a realistic approach, risk means a state of danger, a threat that causes people's desire to protect themselves from possible losses. Risk, in this case, is considered in scientific, technical and economic terms used in economics, statistics, ecology, insurance, epidemiology and emergency management. The starting point of risk here is the concept of danger (harm), as well as statements about the possibility of predicting their occurrence and measuring the consequences. Risk is interpreted as an objective and recognizable fact - a potential danger or already caused harm that can be measured regardless of social perception and cultural environment. At the same time, supporters of this approach recognize that the risk can be misjudged in the framework of one or another way of social interpretation.

In the narrower aspect, risk is understood as activity in the transition from a state of uncertainty to a state of certainty (or vice versa), when a reasonable opportunity to choose when assessing the probability of achieving the expected result, failure and deviation from the goal, taking into account the existing essential norms. It should be emphasized here that risks are constructed through the active perception and selection of people in a process determined by social goals and norms of social activity. On this basis, another scientific area of risk research emerges, focusing on philosophical, social, political and cultural aspects.

We can distinguish the following areas of risk analysis: the cultural and symbolic direction (M. Douglas), the concept of «risk society» (W. Beck and E. Giddens) and the concept of «calculative rationality». Interesting models of sociological studies of risk are also proposed by I. Devyatko and $\mathrm{K}$. Gavrylov. In each of these approaches, there is a moderate and radical line of understanding of risk. Proponents of the moderate concept believe that risk is an objective and subjective reflection of the existing danger. Proponents of radical theory claim that there is no risk as such. One can only talk about the subjective perception of risk, which is due to economic, spiritual, political and social factors and conditions that are specific to a particular social or political situation.

It should be noted that the scientific literature ambiguously interprets the ratio of objective and subjective causes of risk. The objective moment of risk 
is the various conditions, factors, states of collective and individual development, culture, traditions, etc. that exist outside the consciousness of the actor. Risk is objective because it is a form of qualitative and quantitative expression of existing uncertainty. Risk is an attribute characteristic of an activity, because the activity as such is almost always accompanied by uncertainty and the likelihood of finals. On the other hand, risk is the attitude and means of action of the subject, which are based on inherent inherent in him, subjective needs, interests and motives of activity. The subjective nature of the risk is based on the premise that the subject of the action makes the decision to choose a particular alternative of behavior in uncertainty.

Each of these approaches has strong arguments for recognizing both the subjective and objective nature of the risk. Therefore, the subjectiveobjective concept of risk has become most widespread. Its main argument is the recognition that the outside world knows no risk, because it knows neither discernment, nor expectation, nor assessment, nor probability. Thus, risk is the dialectical unity of objective and subjective. Risk researchers note that the subjective-objective nature of risk is also traced in the etymology of the word «risk», which can be interpreted as «maneuvering between rocks», where the former is subjective and the latter is objective.

The presence or absence of analogues of solutions to solve existing risk situations gives reason to speak of ordinary and extraordinary risks. If in the pre-industrial society there were traditional risks, then in the industrial age there are preconditions for technological risks. The latter arise as a result of collective decisions or as a result of the accumulation of a large number of actions by individual social actors. The peculiarity of new risks is that they cannot be the object of direct observation, given their complex nature. As a result, these risks are usually undetermined and their effects are unpredictable.

In the mid-1980's, Perro introduced into circulation the sociology of the notion of «normal accidents», which he understood «inevitable (structurally) failure of technology in complex technological systems - nuclear power plants, petrochemical enterprises, air traffic control systems. As system failures occur due to the complex interaction of technical components, therefore, no fault should be found among the service personnel». According to Perro's words, «the effort to find specific entities responsible for such accidents is driven primarily by the focus on economic growth and the political interests of the economic elite, which underlies the risk assessment 
process itself» ${ }^{4}$. This opinion seems to be quite controversial, which can be agreed upon in the case of technical and technological problems of these systems, which arise in the course of their operation, but are not caused by erroneous technological or design decisions. In other cases, it is wrong to speak of the entire removal of human responsibility for the occurrence of technological disasters, a convincing proof of which is the Chernobyl disaster in 1986.

The risk comes when the number of potential negative consequences can exceed the number of potential positive consequences. In this case, it is a risk as an event (fact), whereas it is necessary to analyze first of all the social and political conditions in which the occurrence of the risk is most favorable and, accordingly, to focus the efforts of the researchers on its prevention or minimization. The focus is on analyzing three types of systems that produce risks in today's society: natural, technological and social.

Although it is not possible to establish a commonly accepted subject definition of the concept of «risk», most scholars note the following essential signs of risk.

- The risk comes from the fundamental uncertainty of reality. Lack of information, the spontaneity of many phenomena that occur in people's lives, limited resources in decision-making and implementation, and the presence of antagonistic tendencies in socio-political development create elements of uncertainty and chaos, creating conditions for risk. The uncertainty category is the basis of an information approach to understanding the nature of risk.

- The probabilistic nature of the occurrence of both adverse and favorable effects of risk. This means that the risk cannot be limited only by the probable loss or damage. Risk carries with it not only the negative but also the positive possibilities, which are taken into account and used as an important point in the decision-making process regarding certain risks. These two aspects of risk - its negative and positive sides - have emerged already in modern times. Probability, in this case, is defined as the objective possibility of an event occurrence.

- Relation of achievement of the set goals and results. Human activity is influenced by factors whose essence and power cannot always be objective and measured in absolute terms. The constant change in the priorities of one interest in relation to others creates situations where the achievement of any results previously considered relevant and productive and in certain

\footnotetext{
${ }^{4}$ Perro J. Crisis hits European car makers. Radio Nederland Wereldomroep. Brussels. October 30, 2008. URL: http://static.rnw.nl/migratie/www.radionethernands.nl/ currrentaffairs/region/Europe/081030-++europe-car-crisis-me-redirected.
} 
circumstances may be reversed among the participants in the political process. Lack of confidence in the subject can lead to arbitrariness and mistakes in assessing the nature of personal and group interests and in conflict situations.

- Orientation to the future. Risk is expressed in reality, which includes elements of goal setting, forecasting and planning of expected states, processes and phenomena. That is, risk appears as a reaction to the situation. As a result, the future risk component makes it a critical setting in the decision-making process and a central category in describing the future. Risk should be seen as a specific form of socio-political communication aimed at assessing the unknown future in the present.

- Controversy. Risk contributes to the implementation of initiatives, innovative ideas, social experiments. This gives you a chance to overcome the inertia, stereotypes and limitations that hinder innovation. On the other hand, it can lead to voluntarism, underestimation of the essential aspects of life, to certain political, socio-economic, legal and moral conflicts. Especially if the decision is made without adequate patterns of development of the situation of preparatory measures.

- Alternative. Risk involves choosing from two or more options. In the absence of a choice, the risk as such is impossible. In this case, the situation can be characterized by a state of «certainty». But, it should be emphasized that refusal to choose is also an option, an alternative. Depending on the specific content of the choice situation, the alternative has varying degrees of complexity and is structured by different means. To do this, we use the classification of problematic situations that require the choice of an alternative. There are three types of tasks: well-structured, poorly structured, and unstructured. Each type of task is answered by a specific set of methods and techniques for analyzing, evaluating and formulating recommendations.

- Evolutionary. Both external and internal risks are able to evolve. Among the risks are the natural selection and the many mechanisms of transformation, conditioned by the nature of the objects in which they must be. Impact on risk involves the answer of reducing its level, but it cannot be completely eliminated because the initial risk will be changed and can be transformed into a number of other risks.

Thus, risk is a concept that has a certain scientific status. As a result of multidimensionality and universality, risk is the object of many interdisciplinary studies, and the term itself is a general scientific concept. Transformation of an abstract concept into concrete terms based on subjective preferences and the transition from conceptual comprehension to operational disclosure of a problem is the main task of any science. 
The concept of risk is linked, according to Giddens, with an active analysis of the danger in terms of future consequences and is therefore widely used only in the future-oriented society for which the future is an area to be conquered or colonized. In this respect, the concept of risk begins to compete with the once basic categories of social development. The future is increasingly being described in terms of risk, not progress 5 .

Theoretical and conceptual approaches to risk determination have been developed in the broadest context of the most extreme states of society and reflect the economic, cultural, political, socio-environmental, legal aspects of risk. This demonstrates the interest in the study of the ricogeneous components of phenomena, both from the representatives of technical knowledge and, to a great extent, by thinkers of the social sciences. The dynamics of the growth of risk concepts reflects the change in the substantive content of risk in the process of development and complexity of structures of modern societies.

At a practical level, we are talking about risk management. The subject of research in risk management is the phenomenon of risk in its various applied levels and is considered, in most cases, in the instrumental aspect. The focus is on analyzing and finding effective means of communication, decision-making and management in situations of risk in certain areas of human life: political risks, business risks, military security risks, psychological and communication aspects of risk, risk management in emergencies legal and enforcement risks, managerial risks.

Another point to be made is the socio-perceptual concept of risk, which defines the parameters of risk perception as a possibility of predicting the risks associated with a subjective decision. In the framework of this concept an attempt is made to study in depth the risk as a factor that shapes the behavioral space of the individual. The risk perception process is characterized as a dynamic process because it is not a constant process and may change over time; so, it is an interactive phenomenon, because individual risk perception is indirect risk perception by the local community. It should be noted that the impact of social institutions on minimizing the impact of risks changes their social interpretation.

$\mathrm{N}$. Luman proposed a scheme to distinguish between risk and danger. Risk is understood here as «an objective and cognitive fact that can change regardless of social or political processes and cultural environment. In today's society there is no risk-free behavior. If for the «risk-reliability dichotomy» means that there is no absolute reliability (i.e. safety), whereas for the «risk-hazard» dichotomy, this means that risk cannot be avoided by

${ }^{5}$ Гидденс Э. Судьба, риск и безопасность. THESIS. 1994. № 5. С. 120. 
making any decision. The better people get to know what they didn't know before, the deeper their awareness of risk becomes. The more rational and detailed the risk measurement becomes, the more aspects of it become known to people» ${ }^{6}$.

Based on J. Ritzer's McDonaldization of Society theory, one can identify the following characteristics of social risk in modern society: «risk becomes compact, which means that risk can be concentrated in compact objects; social risk production is simplified; social risks are «scienced» (from English «science») by their internal structure» ${ }^{7}$.

Proponents of the cultural and symbolic concept try to prove that risk is a socio-cultural fact that differs from natural cataclysm and arises in the case of risk of harm to the subject or object of risk realization or insufficient protection against the danger. Risk-anxiety and risk-tolerance are cultural orientations that influence the level of risk-taking in society.

Cultural and symbolic concepts are represented in three directions: the first is related to the specificity of the culture, which poses a particular level of risk; the second - with historical dynamics as a specific source of new risks; the third - with the development of cultural risk management technologies.

The founder of the theory of «calculative rationality» M. Foucault and his followers focus on explaining how different risk concepts generate specific behaviors that can be used to motivate individuals to participate freely in self-organizing processes in risky situations ${ }^{8}$.

Some researchers, including O. Renn, P.K. Stern, H.V. Feinberg, E. Peters, et al., have proposed a synthetic approach to risk research, pointing to a combination of risk structures and changes in the hierarchy of social values affected by risk. This approach is linked to the concept of risk, which underlies the pursuit of risk or the benefit of it as a life strategy. An attempt to combine the cultural-symbolic approach, the problems of the «risk society» and M. Foucault's arguments in order to give a synthesized understanding of risk as a social phenomenon is to create a socio-cultural theory of risk (works by D. Lapton, P. Kaplan, E. Scott). This area provides

\footnotetext{
${ }^{6}$ Луман Н. Понятие риска. THESIS. 1994. № 5. С. 137.

${ }^{7}$ Ритцер Д. Макдональдизация общества. Москва: Праксис, 2011. С. 56.

${ }^{8}$ Фуко М. Безопасность, территория, население. Лекция 25 января 1978 года. Цикл лекций, прочитанных в Колледж де Франс в 1977-1978 годах. Гуманитарные технологии: Аналитический портал. URL: https://gtmarket.ru/library/articles/6693/6696.
} 
an «important perspective description and examples to study, but limited in theory or discussion» ${ }^{9}$.

\section{CONCLUSIONS}

The gradual awareness of the global community of the fundamental risktaking of any social production stimulates the process of creating technical and social systems that minimize man-made risks. Three fundamentally different but interconnected types of social technologies have been created to combat the risks of the modernization era. Firstly, technology to minimize the production of risk, including closed-loop production. Secondly, the technology of protection against the introduction of industrial safety rules to international collective security systems. The result is an appropriate legislative framework at the international level and active institutions that support certain norms of political risk.

Thus, in risk theory, there are many definitions from different perspectives, as well as its classifications, that illustrate this complex concept. If you try to summarize these definitions, you can combine them into the following two. Risk is defined as a predictable event that could cause damage or harm to someone, that is, have negative consequences. Risk is a specific category that characterizes the deviation of the actual result from what is expected, i.e. there can be both negative and positive consequences from an event or process. The level of risk is almost always proportional to the expected costs caused by the risk event and the likelihood of its occurrence.

Risk theory has reached a new level of cognition when scientists begin to distinguish between theoretical and effective risk, which are related to the concept of eventual risk, which arises when modeling risky situations taking into account the peculiarities of risk perception by the subject. In the case of social risk, the purpose function is to solve social problems and the political aspects are taken into account in the risk factors. For political risk, on the contrary, the purpose function is related to political problems, and indicators of social and economic processes are taken into account when it comes to risk factors.

Assessing the degree of elaboration of the problem of political risk in modern science and the relevance of the study of this phenomenon in modern political processes, we can determine that this problem is stated and studied, above all, in philosophical and socio-economic aspects. The

\footnotetext{
${ }^{9}$ Кривошеїн В. Культурологічна теорія ризику в структурі політичної ризикології. Науковий вісник Ужгородського університету. Сер. Політологія, соиіологія, філософія. 2009. № 12. C. 28-33.
} 
political aspect of the study of this topic is only in its infancy. Theoretical underdevelopment of the problem complicates the management of real political risks, optimization, rationalization of practical management activities in political activity.

\section{SUMMARY}

A study of risk and political risk in the context of adaptation to the conditions of the globalized world, taking into account democratic tendencies, has been made. It is determined that the relevance of the study of risks in politics and political risks is connected with the need to analyze, predict and model the development of political processes in order to preserve statehood and realize their own interests in the framework of democracy. It is justified that the risk theory today has reached a new level of cognition, when scientists began to distinguish between theoretical and effective risk, which are connected with each other by the concept of eventual risk, which arises when modeling risky situations taking into account peculiarities of risk perception by the subject. It is determined that for political risk, the purpose function is related to political problems, and indicators of social and economic processes are taken into account when it comes to risk factors.

\section{REFERENCES}

1. Perro J. Crisis hits European car makers. Radio Nederland Wereldomroep. Brussels. October 30, 2008. URL: http://static.rnw.nl/ migratie/www.radionethernands.nl/currrentaffairs/region/Europe/081030++europe-car-crisis-me-redirected.

2. Гидденс Э. Судьба, риск и безопасность. THESIS. 1994. № 5. C. $116-134$.

3. Горбатенко В. П. Політичні ризики: від теорії до практики. Суспільно-політичні процеси. 2016. Вип. 2. С. 55-69. URL: http://nbuv.gov.ua/UJRN/pubpolpr_2016_2_4.

4. Кривошеїн В. Культурологічна теорія ризику в структурі політичної ризикології. Науковий вісник Ужгородського університету. Сер. Політологія, соціологія, філософія. 2009. № 12. С. 28-33.

5. Левченко М. О. Політичний ризик як один із факторів впливу зовнішньоекономічної діяльності машинобудівного підприємства. Економічний вісник Донбасу. 2011. № 2(24). С. 53-57. URL: http://www.evd-journal.org/download/2011/2011-2/Ek_visnyk_2_2011-5357.pdf.

6. Луман Н. Понятие риска. THESIS. 1994. № 5. С. 135-160. 
7. Найт Ф. Понятие риска и неопределенности. THESIS. 1994. № 5. C. 20-24.

8. Ритцер Д. Макдональдизация общества. Москва: Праксис, 2011. $592 \mathrm{c}$.

9. Фуко М. Безопасность, территория, население. Лекция 25 января 1978 года. Цикл лекций, прочитанных в Колледж де Франс в 19771978 годах. Гуманитарные технологии: Аналитический портал. URL: https://gtmarket.ru/library/articles/6693/6696.

\section{Information about the author:} Pekhnyk A. V.,

$\mathrm{PhD}$ in Political Sciences, Associate Professor, Associate Professor at the Department of Political Theories of the National University «Odessa Law Academy» 2, Academichna str., Odesa, 65009, Ukriane 


\title{
INTRA-PARTY RESTRUCTURING IN THE CONDITIONS OF POLITICAL TRANSIT IN UKRAINE
}

\author{
Kroitor A. V.
}

\section{INTRODUCTION}

In light of current political processes linked to the desire to democratize the political system, the need to restructure party structures in Ukraine plays an important role. Political parties in the context of transit to democracy remain perhaps the most important institution of representative democracy, playing the role of mediator between society and the state on the one hand, and on the other it is not the only significant institution of articulation and aggregation of public interests in the political system. In addition, as part of the mobilization of the masses, the parties ensure their conventional participation in the political process, which ensures the stability of the political system. Through participation in the electoral process, political parties ensure the legitimization of the political system, which ensures its stability.

However, the question of the democratization of party structures remains open, since legitimization of the party elite is not possible in the conditions of maintaining a centralized party structure, with limited influence of ordinary members on the political decision-making process. On the other hand, the question arises as to the effectiveness of the party organization in the inter-party struggle for electoral capital.

The process of forming a multi-party political system in Ukraine in the first stage after the proclamation of Independence is conditioned by the absence of political pluralism, a one-party political system.

According to the opinion of the Ukrainian author B. Gagalyuk, «Modern Ukrainian political parties were formed earlier than formed by social groups, so objectively could not find clear social addresses, become expressions of interests of particular social strata. We should note today the isolation of groups of parties that claim to be sympathetic to virtually the entire 
electorate and, at the same time, function as «business projects» designed to unite and lobby the interests of certain political and economic groups» ${ }^{1}$.

At the same time, it should be noted that the party system of the country is gradually evolving from a one-party to a multi-party system of polarized pluralism with a pronounced regional division, which increases the competition of political parties for control over public authorities.

The characteristics of the modern party system include: increasing the role of parties in the political process, in particular - in parliamentary activities; positioning of political parties, their distribution by the criterion «pro-government - opposition»; formation of a «party of power». In the current context, there is a process of creating party structures based on centers of influence organized around state power institutions; the problem of transforming election technologies into political party activities into an effective democratic governance strategy after the party has gained power; general uncertainty about political ideologies, both in public opinion and in the activities of party structures, the blurring of the right-center-left scale results in the creation of quasi-party groups.

It is a simulation of ideology, which is expressed even in the names of some Ukrainian parties. At the same time, the processes of «ideologizing» political space have two interrelated contexts. On the one hand, postcommunist, when society was tired of the domination of a single totalitarian communist ideology that defined activity in all spheres of public life - from sport and culture to economy and politics.

On the other hand, there are contemporary world-wide transformations of ideologies, under the influence of which the very concept of ideology changes and ceases to be a mere political doctrine; - structuring of political parties around leaders («rating locomotives»), personalization of election campaigns of parties.

Thus, in the process of forming democracy, as an actual form of political interaction in the activities of political parties, one of the main contradictions of the transition period is fully manifested: between full representation of the interests of different social groups and a structured and capable parliament. Obviously, the legitimacy of the government and its political decisions depends on how adequate the representation of group interests in parliament is. However, polarizing the views of political actors and their representation in parliament can slow down or make law-making processes impossible.

1 Гагалюк Б. Концепт «правлячої партії» в умовах парламентаризму: сучасний політичний дискурс. Нова парадигма: Журнал наукових праџь. 2006. Вип. 55. Київ, Вид-во НПУ імені М. П. Драгоманова. С. 152-161. 


\section{Intra-party interaction as a factor of democratization of the political system in Ukraine}

Formation of democracy in the state is complicated by the absence of democratic rules of the game in intra-party interaction. Political parties (ruling or opposition), if they really seek to establish a democratic system in the state, are bound to uphold and protect democratic values and human rights, above all in political parties and intra-party interaction.

The formation of a democratic model of intra-party interaction is complicated by the following factors: limitations and difficulties in the process of horizontal and vertical communication; lack of professional and effective political management; authoritarian style of party leadership; unlimited tenure of office and leadership of the party; insufficient level of political activity and political participation of citizens during the election period; a totalitarian ideology that remains the basis of the programs and activities of some (left and right) parties.

Democracy in party activity is based on the principle of involvement of party members in the party decision-making process, taking into account the political purpose of party activity and party ideology. Freedom of expression of party members, involvement of party members in political activity during election and inter-election periods, gender equality, toleration and tolerance in party relations, defined decision-making procedure, accountability of leaders, etc. The implementation of democratic principles implies publicity and transparency at all stages of the decision-making process, which may conflict with the need for a public demonstration of the party unity sought by each party. That is why the party activity combines the principles of publicity and discussion about the political decision and defines the procedure for its adoption and approval by the party leadership.

Democratization of internal party relations is impossible without effective mechanisms of control by the public, ordinary party members, mass media led by parties. In democratic parties, this is ensured by the presence of powerful party organizations (outlets) on the ground, an extensive network of party representation in all constituencies. At all levels from the community, the district, the region to the capital central office general meetings and meetings of party members, delegates should ensure that the heads of power structures of the respective levels can rely on the mandate given to them democratically.

Each party chooses the mechanism of involvement of ordinary party members in making important decisions and in controlling the activities of the party apparatus. For example, the so-called «women's quota» was set up 
in the Social Democratic Party of Germany when up to 50\% of all party positions and mandates are given to women ${ }^{2}$.

The study of the problems of internal party democracy is one of the main areas of political analysis of the political parties activities. The basis for scientific research on intra-party democracy is the famous iron «law of oligarchy» by R. Michels, who initiated the study of the interaction between the party oligarchy and the masses. ${ }^{3}$

Despite the huge amount of comparative analysis of the internal party structure, there is no consensus in political party studies on clear criteria for assessing democracy and its minimum required so that the party does not lose development dynamics and turn into a regular debate platform.

Within the research of the party model based on the theory of public choice and economic approach to the analysis of political activity, widespread and constant participation of party members in internal party politics and in the recruitment of personnel is considered as a malfunction (dysfunction), because it requires adequate resources, which can be directed to inter-party struggle. In addition, political activity limits the freedom of action of the party leadership and reduces the effectiveness and flexibility of the party organization aimed at achieving the main goal - obtaining the maximum number of votes. The optimal use of the chances of winning the election requires the effective use of available resources (time, people, money, etc.), and this can best be achieved by centralizing power and concentrating decision-making powers in the hands of voter-oriented party leadership. In this way, the formation of intra-party willpower from top to bottom can be achieved.

Based on a model of democracy aimed at satisfying the need to ensure the existence and efficiency of the political system, the whole-systemoriented perspective gives a different scale to assessing the formation of inner-party will. The organizational model of political parties that are relevant to this view is representative, open, responsible, pluralistic, and legitimized by elite domination within the party. This conception of intraparty democracy is based on the premise that «the structure of parties can

${ }^{2}$ Політичні партії України: погляд фахівців. Національна безпека $і$ оборона. 2015. № 6-7. C. 155-156. URL: http://www.razumkov.org.ua/uploads/journal/ukr/NSD155156_2015_ukr.pdf.

3 Лебедюк В. Організаційний баланс ресурсів політичних партій в Україні. Наиіональна бібліотека Украӥни імені B. I. Вернадського: веб-сайт. URL: http://dspace.nbuv.gov.ua/bitstream/handle/123456789/26799/15-Lebedyuk.pdf?sequence=1 . 
only be representative,» as well as on the principle of elite intra-party competition $^{4}$.

The decisive factor of intra-party interaction in the process of political transformation is not the constant communication flow of the formation of ideological and political will from the bottom up, but the election, control, elimination and replacement of intra-party representatives.

Within a democratic model that focuses on the need for legitimation, intra-party democracy is achieved through unrestricted participation of party members in the processes of internal party policy-making. The basis of this concept is the model of formation of inner-party wills from the bottom up, which is clearly oriented to the opinion of ordinary party members. According to this concept, political participation is not limited to simple «participation in organizational matters», but means "participation in decision-making», that is, real participation in binding intra-party decisions at any level of the organization. This concept is inextricably linked to the introduction of an imperative mandate for people`s deputies of all levels.

Based on an intra- party democratic model focused solely on the interests of ordinary party members, any real power within the parties will be essentially undemocratic. At the same time, the analysis is focused mainly on the model of division into ordinary party members and leadership, where the concepts of «leadership» and «oligarchy» become synonymous, and the focus is on the separation and alienation of party elites from other party members. In general, the following criteria are used to assess the state of intra-party democracy: the participation of party members in intra-party work, the participation of party members in policy-making, the participation of party members in the selection of candidates, and the nomination of candidates for elected office.

The internal structure of the party is understood as the organization of the processes of forming the internal party course and political decision-making. In their activities, political parties must adhere to the rules of current law. As a rule, they are free to identify issues regarding their organizational structure, except for certain provisions that are subject to legal regulation in accordance with the law.

The Constitution of Ukraine gives citizens the right to freedom of association in political parties and public organizations to exercise and protect their rights and freedoms and to satisfy political, economic, social,

${ }^{4}$ Плахтій Т. Концепція і стратегія реструктуризації політичних партій в Україні. 2016. 19 жовтня. Хвиля: веб-сайт. URL: http://hvylya.net/analytics/society/kontseptsiyai-strategiya-restrukturizatsiyi-politichnih-partiy-v-ukrayini.html. 
cultural and other interests. ${ }^{5}$ The Law of Ukraine «On Political Parties in Ukraine» puts forward such requirements for the party as all-Ukrainian status, fixed membership, voluntary activity, compulsory registration of an organization with central governing bodies and local branches, program and charter, name, symbolism and registration in the Ministry Justice of Ukraine $^{6}$.

However, domestic legislation does not require political parties to elect and collegial the work of governing bodies, to observe the territorial principle of organizing party structures, to hold conferences periodically, and does not specify the maximum terms of office of party governing bodies and its regional offices.

By defining the rules of political game, the state regulates legislatively issues related to both the functioning and organizational construction of the party. It makes clear requirements for structure, size, territorial scale, election activity, etc.

The party charter fixes the forms of organization, methods of party work and principles of intra-party interaction. The processes of forming a hierarchy within the party, the structure of vertical and horizontal interaction are enshrined in the norms of the charter of a political party.

So, the charter defines the authority of the party congress. If we look at the party charters of the Ukrainian parties, we can see some differences in the interpretation of the role and place of the party congress in the intra-party interaction. So, the chart of the Party of Regions stated that more than half of the elected delegates were sufficient to consider the congress to be authorized. Decisions at the convention shall be taken by a majority vote of the delegates present, except for matters on which the present charter provides for a different decision-making procedure ${ }^{7}$. The same norm is enshrined in the charters of the Socialist Party of Ukraine, the People's Democratic Party and others.

The All-Ukrainian Union «Batkivshchyna» has set other statutory rules for congressional authority. The congress is valid if at least $2 / 3$ of the elected delegates participate in its work ${ }^{8}$. The party's charter contains a rule on the C. 141 .

5 Конституція України від 28.06.1996 р. Відомості Верховної Ради. 1996. № 30.

${ }^{6}$ Про політичні партії в Україні: Закон України від 05.04.2001 р. № 2365-III (зі змінами). Офіційний сайт Верховної Ради Украӥни. URL: http://zakon2.rada.gov.ua/laws/ show/2365-14.

${ }^{7}$ Статут Партії регіонів. Офіиійний сайт украӥнської партї Партія Регіонів». URL: http://www.partyofregions.org.ua/meet/statute/.

${ }^{8}$ Статут Всеукраїнського об'єднання «Батьківщина». Офіційний сайт украӥнської партії «Батьківщинау. URL: http://byut.com.ua/statute.html. 
co-optation of governing bodies (the introduction of new members without additional elections), which violates the principle of election: In the period between congresses, the Political council of the party may, if necessary, within the limits determined by the Congress of the Political council, co-opt its authoritative members of the party and to remove from the Political council those members who are not actively involved in the work or have lost contact with the party»" ${ }^{9}$.

Not all political parties in Ukraine reflect in their charters the norms of activity of deputies of different levels, and when moving to work in state authorities and local self-government, a party member suspends its membership. The harsh conditions of internal party relations are dictated by the provisions of the All-Ukrainian association «Svoboda», which also does not contribute to the democratization of intra-party life. In particular, decisions on the nomination of candidates are made by the party chairman and the party's leading structural units. The party court institute was created in the party. Thus, the charter states that the Party court of UU «Svoboda» (hereinafter referred to as the PC) is a separate structure within the party, which is intended for consideration of complaints, allegations and conflicts of intra-party nature. The Congress of UU «Svoboda» is elected by the Chairman of the Party court of UU «Svoboda». The members of the UU «Svoboda» are elected by the Congress of UU «Svoboda» upon the submission of the Chairman of UU «Svoboda». The provision presented demonstrates the role of the party congress in making personnel decisions.

The charter of the political party «UDAR» (Ukrainian Democratic Alliance for Reforms) of Vitaliy Klichko» declares that the party acts on the principles of voluntariness, equality and mutual respect of its members, collegiality of leadership, observance of internal party discipline and democracy, self-government, legitimacy. Paragraph 9 of the party`s charter states that the procedure for nominating candidates for deputies of the Verkhovna Rada of the Autonomous Republic of Crimea, local councils, candidates for the position of village, settlement, city mayors by local party organizations shall be determined by the Political Council of the Party or the Party Congress. It is stated that the procedure for approving the election programs of candidates for deputies of the Verkhovna Rada of the Autonomous Republic of Crimea, local councils, candidates for the position of village, settlement, city mayors shall be determined by the Political Council of the Party or the Party Congress. These provisions contain important provisions on the democratic procedure for the nomination of candidates for a party by a party congress, which enables the ordinary

\footnotetext{
${ }^{9}$ Ibid.
} 
members of the party to be involved in the procedure for nominating candidates for deputies.

However, in the charters of political parties in Ukraine, insufficient attention is paid to the mechanisms of increasing the activity of ordinary party members and their involvement in the process of party decision making (in particular, regarding the nomination of candidates for deputies). At the same time, the organizational and political functions of the Party Congress are often duplicated by the powers of the Political Council of the Party and the executive committee, which are essentially in charge of intraparty relations.

Analyzing the statutory documents of modern political parties, we can agree with I. Zhdanov's conclusion about the significant influence of the Soviet past on the activities of political parties in Ukraine: «A key feature of the evolution of political parties in Ukraine (as in most post-Soviet countries) is that the CPSU has been and remains the main model for the way of formation, drafting of documents, registration, logic of internal system functioning and specificity of participation in political processes ${ }^{10}$.

One of the main reasons for the closeness of party decision-making and the opacity of intra-party interaction is the problem of financial support for both the current activity of party structures and the party's participation in election campaigns. In these circumstances, the political space is dominated by «leadership» type parties that represent the interests of certain financial and industrial groups. It is worth agreeing that «only one function is $100 \%$ fulfilled - the struggle for power» ${ }^{11}$. One of the reasons for the lack of internal party democracy in the modern political parties of Ukraine is the low level of political activity and participation of citizens and party members in the development, adoption and implementation of internal party politics.

In the electoral period, the activities of a political party are aimed at achieving a certain result, which involves taking into account public opinion, voter motives. One of the main factors capable of supporting voters is the activity of the party leader (the «rating engine» that heads the party's electoral list).

On the one hand, identifying a party with a leader facilitates the positioning of a political party in the electoral space, streamlines the choice of citizens, reducing it to the parameter of evaluating the leader's activity, simplifies it. On the other hand, it encourages the creation of leadership-type

10 Жданов I., Якименко Ю. Нові обрії української багатопартійності. Дзеркало тижня. 2003. № 24. URL: http://gazeta.dt.ua/POLITICS/novi_obriyi_ukrayinskoyi_ bagatopartiynosti.html.

${ }^{11}$ Ibid. 
parties with authoritarian internal organization and focuses the party's election campaign solely on the personality of the leader and his promises, not ideology and programmatic foundations.

To this should be added the process of blurring the ideological base, the convergence of ideologies, which also causes problems for the democratization of party and political interaction, and turns even ideological parties into «voting machines». The intra-party struggle is focused not on ideological discussions, but on defining the leader and asserting his influence, slows down unification processes and the creation of large nationwide parties.

The lack of a defined effective model of intra-party interaction leads to permanent crises in the political party, loss of electoral support and disintegration. The lack of institutionalization of intra-party democracy leads to failures in the system of evolutionary change of party leadership, and consequently to the development of a political party. An example is the situation with a number of schisms in the Political Party «Nasha Ukraina» (formerly called the People's Union «Nasha Ukraina»). So, « the intra-party relations in «Nasha Ukraina», although not marked by the particular dictate of the party leader, but had a typically oligarchic structure of interaction where the party leadership restricted the real functioning of intra-party democracy, as evidenced by the procedure for nominating candidates for deputies. The loss of power by the party caused tensions in the intra-party struggle that spilled over into divisive congresses.

For example, the former chairman of the Political Council of «Nasha Ukraina» Sergiy Bondarchuk said that in the 2012 parliamentary elections, the party fulfilled a «technical task in the interests of the Party of Regions $\rangle^{12}$. On February 9, 2012, Bondarchuk announced his removal from the party of Honorable President Viktor Yushchenko. March 2 Congress «Nasha Ukraina» chaired by S. Bondarchuk decided to liquidate the party. However, part of V. Yushchenko's supporters gathered for an alternative congress, expelling S. Bondarchuk from the party, which gave reason to the Ministry of Justice of Ukraine refused to register the submission of the chairman of the political council of the Party «Nasha Ukraina» on the termination of the party's activity. The political process of intra-party struggle illustrates the tensions in the party, the complexity of the processes of democratization of interaction between members of the political party horizontally and vertically.

12 3'їзд Бондарчука прийняв рішення про саморозпуск «Нашої України». Дзеркало тижня. 2012. 2 брезня. URL: http://zn.ua/POLITICS/sezd-bondarchuka-prinyal-reshenieo-samorospuske-nashey-ukrainy-118067_.html. 
As an example of forming an effective model of intra-party interaction, we can cite the activity of the Party of Regions, which gained power due to the well-considered position of the party leader regarding various groups of influence and the rigid organizational structure of intra-party interaction during the election period.

Considering the former Party of Regions in terms of intra-party relations, it should be noted that it was a «hierarchical political organization with strong centralism and influence of the party leader on the political decisionmaking process $\rangle^{13}$. This is a prominent party-type party whose leader became the President of Ukraine (as the first party president, not just an honorary party leader). This indicates an increase in the influence of parties in the political system. It is worth noting that the political parties of Ukraine are characterized by an image attachment to its leader, since after V.F. Yanukovych to the Russian Federation, the Party of Regions lost its leader and ceased to exist.

It can be argued that the process of intra-party interaction is characterized by an increasing role of the leader in forming the party organization, control over the processes of personnel rotation by the party leadership, exacerbation of conflicts within the parties during the election period, when there is a distribution of seats in the party lists. The development of intraparty interaction demonstrates a certain dependence of the state of internal democracy in parties on the level of political culture (not only in parties, but also in society as a whole). The activities of party structures are affected by the contradictory nature of society's development.

The main principles of intra-party democracy in the transition period are the election of governing bodies, periodic reporting of leadership to ordinary party members, collegiality in the work of governing bodies, personal responsibility of each party member for the performance of duties and powers, the supremacy of the congress as expression of the will of the whole party, democracy at the stage of discussion and discipline in the implementation of decisions after its adoption, bottom-up criticism, publicity and public nature of the action ${ }^{14}$.

An important component of intra-party interaction is the activity of party leaders, who often play a decisive role in the process of developing and implementing organizational strategies of political parties. Functional features of the party leader's activity consist in the ability to compensate for

13 За часів президентства Януковича ПР перетворилася на аналог радянської партії. Правда. 2013. 18 березня. URL: http://pravda.if.ua/print.php?id=37382.

${ }^{14}$ Кройтор А. В. Полухіна А. В. Реструктуризація внутрішньопартійної організації як виклик сучасної доби. Актуальні проблеми політики. 2017. Вип. 60. С. 223-234. 
the low efficiency of the party's organizational, human and program resources. The phenomenon of party leadership implies the primacy of the individual in government structures, political parties and pressure groups.

\section{Restructuring of political parties of Ukraine in the conditions of democratization}

Among the problems of the implementation of the intra-party process there are the following provisions:

Firstly, the primary focuses on reviewing and evaluating party documents and strategies proposed by management; delegates their representatives to party congresses; makes proposals for candidates for deputies of Ukraine. Candidate lists are «batch-approved» by party congresses. However, the procedure for forming the lists of candidates for deputies of Ukraine is not clearly spelled out either in the statutory documents of political parties or at the legislative level. Under the charters of some parties, considerable powers are conferred on governing bodies. However, only in some cases it is assumed that the governing bodies of the parties are made taking into account the regional representation.

Secondly, party leaders seek conservatism and strengthen their power by concentrating several positions in the party apparatus.

Thirdly, party leaders seek to prevent ordinary members from making decisions, creating the illusion of their participation.

The traditionally predetermined electoral orientation of the Ukrainian population to personalize the political process and party organizations leads to an increased role of the leader. Increasing the role of party leader may result in a tendency that manifests in the inclination of party leaders to concentrate power in their hands. Such a development of party life will inevitably lead to the party's transformation into a rigid, authoritarian, closed structure to serve the interests of party leadership and, as a consequence, to its split in the future. Conflict may be triggered by the influence of new activists, who may be more powerful than the «old» functionaries, with significant restrictions on party careers.

Intra-political conflicts «can occur at different levels of party functioning: at the level of central leadership, within grassroots organizations, between grassroots party organizations and the center» ${ }^{15}$.

In recent decades, another important trend has clearly emerged in party activities. Regardless of political ideology and internal party structure, political parties began to focus in their activities on communicative

${ }^{15}$ Шведа Ю. Р. Теорія політичних партій і партійних систем. Львів: ЦПД, 2002. 528 с. 
technologies of influence on society (political advertising, propaganda, political PR). Gradually, this global trend has spread to Ukraine, creating the conditions for politicization of politics, transformation of politics into a media process, emergence of phenomena of «real virtuality» and «virtual democracy». Political parties, like ordinary companies that want to sell their goods, hold party events as PR promotions. First and foremost, it is about staging and directing party congresses that turn into a live show and are being shown live. At the same time, experts note that during such congresses, you can see many elements, the sources of which reach back to the Soviet traditions of celebrations.

With such a visual appeal, the intra-party activities of elites and leaders are characterized by secrecy, conflicts do not become public, and are ignored by official websites and other media resources of the parties. As a rule, party leaders, related to financial and economic interests, silence disputes that occur in intra-party interaction.

Functional features of the process of intra-party interaction at the present stage are also determined by the following factors.

Firstly, political parties are focused not on ideology, but on the communication technologies of organizing political (especially election) campaigns. Political parties' programs have a contradictory combination of liberal principles in the party's economic and political doctrine and socialist and paternalistic provisions (promises of wages and pensions, abolition of pension reform, etc.).

Secondly, the Law of Ukraine on Civil Service No. 4050-VI, which forbids public servants from membership in political parties, is directly related to domestic political activity. A civil servant is required to terminate membership of a political party prior to his or her appointment. The ban on the party affiliation of a civil servant and the need to leave the party immediately after his or her appointment, on the one hand, complicates the participation of a civil servant in elections, and on the other, it deprives political parties of a large layer of educated, qualified individuals, who in many cases form the core of the party organization itself. The aspirations of civil servants to be elected, as well as the interest of political parties in their list of influential, and in some places well-known officials, will inevitably transfer relations between officials and political parties into the informal shadow sphere.

To overcome the oligarchization of the party structure, a prerequisite is the provision of the possibility of influence of ordinary party members on party politics, nomination of candidates in internal party elections, transparency of the decision-making process at the local and central levels of 
the party organization, freedom of intra-party debate, criticism of party organs, in fact, and the basis of intra-party democracy. Thus, in the process of democratization of Ukrainian society an important role belongs to the mechanisms of building of intra-party relations on the basis of democratization.

M. Oferle views political parties as companies that are struggling to make a profit. Thus, the parties as an entrepreneur in the market should exchange their ideas, values, statements in the program in support of the electorate. It is because of this support that the party gains power, and therefore not only the effectiveness of the election campaign, but also the further development of the party depends on a rationally organized internal party structure.

Therefore, the restructuring of a party organization should be understood as qualitative changes in the internal party structure, the introduction of which will not only democratize intra-party interaction, but also enhance the competitiveness of the party in the party market in the struggle for electoral capital. The concept of restructuring, as T. Plakhtiy points out, is the idea of a systematic analysis that the external qualities of systems, in particular the social ones, which are organizations, are determined by their structure. That is, in order to change the qualities of an organization, it is necessary to change its structure or, in other words, to carry out its restructuring.

G. Morgan determines that the effective structure of any organization in a market environment is determined primarily by the challenges facing the organization. That is, in conditions of stable functioning, when the external environment does not form new requirements, the organizational structure has a hierarchical system of formal positions that ensures the day-to-day management of the organization. In addition, the responsibility for the performance of each actor depends on his place in the hierarchy, that is, the higher the level of the organizational pyramid is held by the person, the higher the level of his responsibility in the system of making and implementing intra-structural decisions ${ }^{16}$. With the changing environment that creates new challenges to the system, the management system should be changed towards decentralization and redistribution of roles within the organization.

Considering the structure of domestic parties, it becomes clear that they are centralized and rigidly hierarchized organizations with limited levels of intra-party democracy. This is evidenced by the statutory documents of the

${ }^{16}$ Плахтій Т. Концепція і стратегія реструктуризації політичних партій в Україні. 2016. 19 жовтня. Хвиля: веб-сайт. URL: http://hvylya.net/analytics/society/kontseptsiyai-strategiya-restrukturizatsiyi-politichnih-partiy-v-ukrayini.html/ 
parties. In particular, the party charter fixes the forms of organization, methods of party work and principles of intra-party interaction. The processes of forming a hierarchy within a party, the structure of vertical and horizontal interaction are enshrined in the norms of the charter of a political party.

Also in the charters of political parties in Ukraine, insufficient attention is paid to mechanisms of increasing the activity of ordinary party members and their involvement in the process of party decision-making (in particular, regarding the nomination of candidates for deputies). At the same time, the organizational and political functions of the party congress are often duplicated by the powers of the Political Council of the party and the executive committee, which are essentially in charge of intra-party relations.

One of the main reasons for the closeness of party decision-making and the opacity of intra-party interaction is the problem of financial support for both the current activity of party structures and the party's participation in election campaigns.

At the present stage of development of the political system of Ukraine, there is a transformation of the party system related to the return to the parliamentary-presidential republic, which envisages the formation of a coalition in parliament for the purpose of forming a government, and changes in the electoral system. However, there remains a tendency to dominate leadership-type parties that represent the interests of certain financial and industry groups. At the same time, there are two exceptions to this trend.

Firstly, the political party «Opposition Bloc», formed on the remnants of the once influential Party of Regions with the loss of a «leader-face» and the inability of one of the party's new leaders to embody a party brand, offered such a phenomenon as party co-ordination.

Secondly, from the context of leadership parties, the Ukrainian Patriots Union - «Ukrop», which, although has a formal leader, stands out, but in the public consciousness, its image is not identified with the political party brand. In addition, it should be noted that the new changes to the wording of the charter of a political party indicate a certain, well-considered tendency to democratize intra-party relations. Thus, in the charter of a political party, in order to increase the activity of ordinary party members, there are provided means of encouragement. And a mechanism was created that prevents usurpation of power in the Party, the so-called «1/3 right.» According to these norms, $1 / 3$ of lower-level organizations may initiate a vote of no confidence in top-level executives, and such issues should be considered by the top governing body of such organization. This applies to both the Heads 
of Committees of the primary cells and the Chairman of the Party. In addition, the regional structure of the party introduced primary cells that are created within the streets, neighborhoods, micro-districts in cities or within a village, settlement, united territorial community, city of regional importance $^{17}$. Statutory innovations should also include the extension of the rights of party members to influence the formation of the party's electoral list approved by the congress, as well as the right to challenge decisions of party governing bodies. In this way, ordinary members of the party are given the opportunity to influence the decision-making process within the party ${ }^{18}$.

On the whole, most political parties in Ukraine are characterized by centralization of party management and limited intra-party democracy.

In the electoral period, the activities of a political party are aimed at achieving a certain result, which involves taking into account public opinion, voter motives. One of the main factors that can support voters is the activity of the party leader (the «rating engine» that heads the party's electoral list). On the one hand, identifying a party with a leader facilitates the positioning of a political party in the electoral space, streamlines the choice of citizens, reducing it to the parameter of evaluating the leader's activity, and simplifies it. On the other hand, it encourages the creation of leadership-type parties with authoritarian internal organization and focuses the party's election campaign solely on the personality of the leader and his promises, and not on ideology and programmatic principles.

Given this unambiguous need for domestic parties is the need for their restructuring, which will ensure the formation of an effective organizational structure capable of responding to the current challenges of the political process. Such restructuring implies the replacement of the classic hierarchical structure with a mobile organization that would take into account the regional peculiarities of the party structure and ensure a proper level of intra-democratic democracy with a high range of role-playing functionalization. In this way, bodies responsible for various functions will be created within the party structure, and power will be distributed in proportion between these bodies. In addition, temporary structures of specialists should be created within the party to ensure the management of individual projects aimed at solving specific tasks, especially during the election period. The restructuring of the party structure will ensure the

17 Статут Партії «Українське об’єднання патріотів - УКРОП!». Офіиійний сайт украӥнської партії Украӥнського об'єднання патріотів. URL: http://www.ukrop.com.ua/ uk/about/statut.

${ }^{18}$ Кройтор А. В. Полухіна А. В. Реструктуризація внутрішньопартійної організації як виклик сучасної доби. Актуальні проблеми політики. 2017. Вип. 60. С. 223-234. 
redistribution of power within the party organization, as well as ensure the activity of the members of the lower level of the party structure by reducing the leadership role of the party nucleus in controlling information flows and making management decisions.

Some scholars believe that party restructuring in Ukraine does not happen because parties are more of a leader type and party leader is a party brand without which it is impossible to conduct a successful election campaign. That is why party leaders do not allow for decentralization of internal party management.

However, we must disagree with this view, since restructuring parties does not necessarily lead to a change in party branding. In terms of image technologies, the election campaign may continue to focus on the image of the party leader as a «symbol» of the party, in case such a strategy ensures the party's victory.

Modern party organizations, in their unalterable form, turn into uncompetitive goods, the sale of which is too expensive for their leaders. In view of this, T. Plakhtiy states: «The decline of political parties compels their leaders to appeal to more powerful organizations - oligarchic clans with financial support for access to the media in order to maintain the relevance and awareness of their brand, which for the reasons stated above is not true. This leads to the loss of independence of political parties and the establishment of external control over them by the oligarchic clans, who thus become the main beneficiaries of their activities» ${ }^{19}$. It is through these processes that political parties from the institutions of articulation of the interests of society are transformed into a mechanism of channeling the interests of individual oligarchic groups in the center of decision-making, which in the conditions of a parliamentary-presidential republic is a parliament. As a result, only the core of the organization and the governing bodies on the ground remain in effect.

We cannot but agree with T. Plakhtiy, who argues that the restructuring of Ukrainian political parties involves the choice of: a variable structure of political organizations; dynamic network and principles of its operation; the totality of all its internal organizational processes; systems of control over the flow of internal organizational processes; the order of deployment of the variable structure; concepts of activity of political organizations with a variable structure - a dynamic network that covers the main tasks of the activity, requirements for the activity, structured field of activity,

19 Плахтій Т. Типовий і оптимальний шляхи розвитку політичних організацій за методологією. 2015. 10 липня. Хвиля: веб-сайт. URL: http://hvylya.net/analytics/society/ tipoviy-i-optimalniy-shlyahi-rozvitku-politichnih-organizatsiy-za-metodologiyeyu-adizesa.html. 
methodology of activity, technological process of activity; fundamentals of financing political organizations with a variable structure - a dynamic network ${ }^{20}$.

Such restructuring should not only ensure the effectiveness of parties as an «enterprise» in the political market, but also meet the needs of democratization of the internal structure, which will reduce the level of oligarchicism of the party. Intermediate parties with a high degree of participation in the governance of its members will ensure not only the legitimization of the party elite, but also in the aftermath of the elections, ensure the legitimacy of the entire political system, and therefore its stability and democratization.

It should be noted that after the Revolution of Dignity, there were changes in the technologies of political parties' construction, both those formed before 2013 and those that formed their structures in the revolutionary and post-revolutionary period. V. Karasyov notes: «From the point of view of construction, political parties began to form more from the bottom, based on the active civic position of the people. Parties are intensively engaged in rebranding, recruiting new staff on the basis of active cooperation with new political actors - activists, «new heroes» (ATO participants, volunteers, etc.), public organizations. New parties are horizontal, not vertical, civic rather than leadership parties»» ${ }^{21}$.

Certainly, the main ideological focus of political parties today is focused on patriotic, human rights and integration directions. Parties try to help people protect their rights from arbitrary rule, corruption, injustice. The nature of party activities is also changing. Parties are increasingly working in the field, organizing and actively participating in pickets, rallies, flash mobs, protests. The type of interaction with supporters is also changing. This is facilitated by the active use of social networks and mobile technologies, crowdsourcing and more. However, in contrast to V. Karasyov, A. Kolodiy denies the scale of changes in the processes of party organization in Ukraine, in particular the researcher points out: «The Maidan did not have much influence on the ways of creation of political parties and their typology. The political component of the Maidan was weak and did not respond to the challenges that Ukraine's political system faced. Instead of leading, the leaders of the opposition at the time were adapting, and the public sector

${ }^{20}$ Плахтій Т. Концепція і стратегія реструктуризації політичних партій в Україні. 2016. 19 жовтня. Хвиля: веб-сайт. URL: http://hvylya.net/analytics/society/kontseptsiya-istrategiya-restrukturizatsiyi-politichnih-partiy-v-ukrayini.html.

${ }^{21}$ Політичні партії України: погляд фахівців. Національна безпека і оборона. 2015. № 6-7. C. 155-156. URL: http://www.razumkov.org.ua/uploads/journal/ukr/NSD155156_2015_ukr.pdf. 
could neither identify from among its new political leaders nor create a mass movement on the basis of which a new organized political force would emerge». Conditionally dividing parties into «old» and «new» researcher refers to the new parties «Petro Poroshenko Bloc», «Narodny Front» and «Samopomich» (which gained national significance only after the Maidan), as well as «Opposition Bloc». To the old - «Batkivshchyna, O. Lyashko Radical Party, UU «Svoboda», «Civic Position». Undoubtedly, the BPP is organized under a leader and is a universal type party. This is evidenced by the lack of a clear ideology, and the election platform has actually become a program of party activity. Structurally, the party is organized around a leader, which is the engine of its rating.

«Samopomich» is somewhat more open-minded, closer to civil society and its demands, and a member of the faction on voting. At the same time, the party is approaching two previous parties with a leader, with strong managerial functions.

The analysis of party structures of Ukraine at the present stage of functioning allows to make the following conclusions: parties remain, to a greater extent, financially dependent on oligarchic groups, performing the function of representing the interests of these groups in parliament; for the most part, modern parties are not classical parties, because they do not have extensive networks of primary centers whose activities are formal; parties maintain a centralized, hierarchical structure, with low levels of intra-party democracy.

\section{CONCLUSIONS}

Therefore, given all of the above, a successful political party in Ukraine that would be independent of the oligarchy and based on an extensive decentralized, non-leadership structure could become a party that represents the interests of the middle class. The internal structure of such a party should be based on an adhocratic basis, with a dynamic and extensive management network. T. Plakhtiy notes that participation in party activities should be based on three-level membership: level 1 - members of the organization who systematically participate in the meeting and execute, coordinate, make and implement all decisions; level 2 - candidates for membership of the organization who can optionally attend the meeting with an advisory vote and participate in the implementation of part of the decisions; level 3 supporters who are interested in the activities of the organization and 
optionally take part in activities that it organizes as part of its statutory activities $^{22}$.

At the same time, the structure of the party in different regions of the state should have appropriate units that would work on the solution of highly specialized problems, taking into account the regional peculiarities of the electorate. It should be noted that the structural organization of the party must be variable according to the situation in the external environment. Thus, the main link of the party structure representing the dynamic network is the regional branch of the party. The decision in the party branch of the regional level should be made collectively, through the method of brainstorming, which will allow finding non-standard approaches to solving both current and strategic issues of party functioning.

District and local party units are organized with a small number of permanent members, each of whom is engaged in the implementation of separately set tasks, creating an organizational group that is liquidated or reorganized according to the professional and creative abilities of team members after solving the tasks. This eliminates the need for a hierarchical organization of local party cells based on a permanent structure. The central governing bodies of the party make decisions by coordinating the positions of the regional centers in all directions and profiles of party activity, taking into account the regional specificity.

Therefore, it is precisely through the restructuring of an internal party organization on the basis of democratization that the path to the success and independence of political parties and their transformation into a real institution of articulation and aggregation of interests of society, rather than individual oligarchic groups, will be provided, which will ensure the successful process of democratization of the entire political system of the state system.

\section{SUMMARY}

The article is dedicated to the pressing issue of political science - the study of the intra-party structure and the need for its restructuring in the process of democratization in Ukraine. The specificity of the Ukrainian political parties' internal party organization and the needs of their restructuring in the current conditions of the political process are analyzed. The structures of individual political parties are analyzed on the basis of the study of party charters. It is noted that the main tendency of intra-party

${ }^{22}$ Плахтій Т. Концепція і стратегія реструктуризації політичних партій в Україні. 2016. 19 жовтня. Хвиля: веб-сайт. URL: http://hvylya.net/analytics/society/kontseptsiya-istrategiya-restrukturizatsiyi-politichnih-partiy-v-ukrayini.html. 
functioning is oligarchization of the internal-party structure of the majority of political parties of Ukraine. It was determined that the restructuring of the party structure should be carried out on the basis of democratization of intraparty relations, and decentralization of the system of party management on the basis of building a dynamic, networked party structure, which is an important factor in the democratization of the domestic political system.

\section{REFERENCES}

1. Бутусов Ю. Донецьк в епоху фракційної роздробленості. Дзеркало тижня. 2005. № 15. URL: http://gazeta.dt.ua/ARCHIVE/ donetsk_v_epohu_fraktsiynoyi_rozdroblenosti.html.

2. Гагалюк Б. Концепт «правлячої партії» в умовах парламентаризму: сучасний політичний дискурс. Нова парадигма: Журнал наукових пращь. 2006. Вип. 55. Київ, Вид-во НПУ імені М. П. Драгоманова. С. 152-161.

3. Головатий М. Ф. Професія - політик. Кіїв: Парламентське видво, 2000.88 с.

4. Головатий М. Ф. Соціологія політики: [навч. посіб. для студ. вищ. навч. закл.]. Київ: МАУП, 2003. 504 с.

5. Жданов I., Якименко Ю. Нові обрії української багатопартійності. Дзеркало тижня. 2003. № 24. URL: http://gazeta.dt.ua/POLITICS/novi_obriyi_ukrayinskoyi_bagatopartiynosti.h tml.

6. 3’їзд Бондарчука прийняв рішення про саморозпуск «Нашої України». Дзеркало тижня. 2012. 2 брезня. URL: http://zn.ua/POLITICS/sezd-bondarchuka-prinyal-reshenie-o-samorospuskenashey-ukrainy-118067_.html.

7. За часів президентства Януковича ПР перетворилася на аналог радянської партії. Правда. 2013. 18 березня. URL: http://pravda.if.ua/print.php?id=37382.

8. Конончук С. Г., Ярош О. А. Основні процедури внутрішньопартійної демократії. Аналітичний. Київ: Український незалежний центр політичних досліджень, 2012. 96 с. URL: http://www.ucipr.kiev.ua/userfiles/party_\%20democracy2012.pdfa.

9. Конституція України від 28.06.1996 р. Відомості Верховної Ради. 1996. № 30. С. 141.

10. Кройтор А. В. Полухіна А. В. Реструктуризація внутрішньопартійної організації як виклик сучасної доби. Актуальні проблеми політики. 2017. Вип. 60. С. 223-234. 
11. Лебедюк В. Організаційний баланс ресурсів політичних партій в Україні. Національна бібліотека Украӥни імені B. I. Вернадського: веб-сайт. URL: http://dspace.nbuv.gov.ua/bitstream/ handle/123456789/26799/15-Lebedyuk.pdf?sequence $=1$.

12. Михельс Р. Социология политической партии в условиях демократии. Диалог. 1990. № 5, 9; 1991. № 4. URL: http://www.read.virmk.ru/m/Mixels.htm.

13. Плахтій Т. Концепція і стратегія реструктуризації політичних партій в Україні. 2016. 19 жовтня. Хвиля: веб-сайт. URL: http://hvylya.net/analytics/society/kontseptsiya-i-strategiyarestrukturizatsiyi-politichnih-partiy-v-ukrayini.html.

14. Плахтій T. Типовий i оптимальний шляхи розвитку політичних організацій за методологією. 2015. 10 липня. Хвиля: вебcaŭm. URL: http://hvylya.net/analytics/society/tipoviy-i-optimalniy-shlyahirozvitku-politichnih-organizatsiy-za-metodologiyeyu-adizesa.html.

15. Політичні партії України: погляд фахівців. Національна безпека $i$ оборона. 2015. № 6-7. C. 155-156. URL: http://www.razumkov.org.ua/uploads/journal/ukr/NSD155156_2015_ukr.pdf.

16. Про політичні партії в Україні: Закон України від 05.04.2001 p. № 2365-III (зі змінами). Офіиійний сайт Верховної Ради України. URL: http://zakon2.rada.gov.ua/laws/show/2365-14.

17. Саймон Г. А. Адміністративна поведінка: Дослідження процесів прийняття рішень в організаціях, що виконують адміністративні функції; пер. з англ. Київ: Артек, 2001. 392 с.

18. Статут Всеукраїнського об'єднання «Батьківщина». Офіиійний сайт української партії «Батьківщина». URL: http://byut.com.ua/statute.html.

19. Статут Партії «Українське об’єднання патріотів - УКРОП!». Офіиійний сайт украӥнської партії Украӥнського об 'еднання патріотів. URL: http://www.ukrop.com.ua/uk/about/statut.

20. Статут Партії регіонів. Офіційний сайт украӥнської партії «Партія Регіонів». URL: http://www.partyofregions.org.ua/meet/statute/.

21. Шведа Ю. Р. Теорія політичних партій і партійних систем. Львів: ЦПД, 2002. 528 с.

22. Шевчук О. А. Роль засобів комунікації у формуванні політичних цінностей українського суспільства. Політична наука в Украӥні: стан $i$ перспективи: матеріали всеукраїнської наукової конференції (Львів, 10 - 11 травня 2007). Львів: ЦПД, 2008. С. 183-188. URL: http://postua.info/anisimovych.htm. 
23. Шимонова О. Виборчі списки як індикатор внутрішньопартійної комунікації. Українська національна ідея: реаліі та перспективи розвитку. 2009. Вип. 21. С. 180-184. URL: http://dspace.nbuv.gov.ua/bitstream/handle/123456789/25722/36-

Shimanova.pdf? sequence $=1$.

\section{Information about the author:}

Kroitor A. V.,

$\mathrm{PhD}$ in Political Sciences,

Associate Professor at the Department of Political Theories of the National University «Odessa Law Academy»

2, Academichna str., Odesa, 65009, Ukriane 
DOI https://doi.org/10.36059/978-966-397-158-2/175-190

\section{FEATURES OF POLITICAL STABILITY IN UKRAINE IN THE CONDITIONS OF POLITICAL TRANSIT}

\section{Kozminykh A. V.}

\section{INTRODUCTION}

The study of the features of political stability in Ukraine in the conditions of political transit requires an integrated study. For this purpose it is important to define the concepts and components of political stability, to consider the phenomenon of political transit, its characteristics and peculiarities, as well as to determine what place Ukraine occupies in these processes at the present stage of its development. It is through this knowledge that we can analyze the features of political stability in our country and determine the effectiveness of the mechanisms designed to provide it.

Many scholars have approached the study of the problem of political stability at different times, which can be roughly divided into several groups. The first group of researchers may include scholars studying the theoretical and methodological features of transit processes, in particular modernization (W. Beck, R. Bendix, S. Black, M. Levy, U. Rostow, S. Huntington, P. Stompka, S. Eisenstadt, R. Inglehart, T. Carl, T. Carothers, A. Croissant, X. Linz, S. Lipset, B. Merkel, A. Perevorsky, D. Rostow, A. Stepan, etc.) and transformation (I. O. Batanov, V. Ya. Gelman, T. I. Zaslavskaya, V. V. Lokos, V. O. Yadov, I. S. Yazhborovska, and others).

Another group includes works devoted to the formation of new and functioning of traditional institutions in the conditions of transformation of the political system of society (M.G. Anokhin, L.E. Blacher, S.V. Volodenkov, A.Yu. Zudin, I.M. Igoshin, S.G. Kirdina, A. Rybakov and others). Many theoretical propositions and questions of applied political science were investigated by M.G. Anokhin, A.V. Krutov, L.V. Postnikov, Yu. Semygin, A.F. Shabrov.

The third group is formed by studies that discuss the features of political transformation in the post-Soviet space and Ukraine (V. Bani, R. Darendorf, G. O’Donnell, I.B. Kiyanka, N.O. Latigina, M. McFall, K. Offe, C. White, A. Schleifer and others). 
It should be noted that, despite the considerable amount of research in this field, they all have sufficiently noticeable segmentation, which lacks the most comprehensive approach to studying the features of political stability in Ukraine in the context of political transit.

Therefore, the purpose of the study is to identify and analyze mechanisms that can effectively ensure the political stability of the modern Ukrainian state in the current political transit conditions.

First of all, in order to study the features of political stability in Ukraine in the context of political transit, it is necessary to clarify the concepts of political stability, identify the factors that influence this phenomenon, as well as those criteria that allow us to assign a particular political system to the category of stable or unstable.

The need for political stability is a priority for any state, regardless of political regime, economic development, historical or cultural factors. Political stability is often found in the major constitutional documents of many countries of the world as a priority area of state policy in the field of national security. Maintaining the stability of the political system is one of the guarantees of the security of the state, which is able to respond adequately to the challenges and threats to its existence, both domestically and externally.

Political stability is derived from the influence of many factors on the political system of society: the trust of citizens to the authorities, the consensus of the elites in the directions of the country's development, the progressive economic growth, social well-being, the type of political culture, a strong state, constructive inter-ethnic and inter-denominational relations, etc. Moreover, the full development of the political system requires stability in all these areas.

\section{Political stability in conditions of political transit and the main mechanisms of its support}

Despite the fact that the term «political stability» is quite widespread and is very common in the scientific literature, there is still no common position among scientists to define it. In order not to dwell for a long time on the discussions on the essence of political stability, it should be noted that regardless of the regime, the type of legitimacy of power and other factors, it is characterized by a balanced state, both in domestic and foreign relations.

In the most general sense, political stability should be understood to mean such a state of the political system of society, which preserves and reproduces the essential identity of such a system, the stability of the political regime and forms of government, the protection of the 
constitutional order in the country, as well as the preservation of civil peace and understanding in the country.

We emphasize an important characteristic - the notion of political stability reflects not the static but the dynamic state of political structures and relations. It allows the political system to retain its basic parameters and characteristics over time, preserving its basic characteristics and trends of political development, and without being subjected to destabilizing influences. Let us agree with the opinion of some authors that political stability should be understood as the stability of the political system, which expresses the fundamental interests of the main social groups and ensures the socio-political stability of society and the absence of acute social and political conflicts in it ${ }^{1}$.

In a stable political system, there is a certain balance in political and social forces, which makes it possible to use political mechanisms effectively, both to maintain the status quo and for progressive development and to carry out reforms and transformations that are positive for society. At the same time, it would be justified to say that the lack of such a balance in the political space either leads to destabilization or is a sign of pre-existing instability of the political system.

The destabilizing aspects of the political system can be divided into the following types: the systematic type of destabilization implies violations in the system of regularities and tendencies of holistic, complex development and stability of all institutions of the political system; cognitive appearance is based on the distribution of powers between individuals, where destabilizing factors operate contrary to the reasonable and rational distribution of such powers, and aimed at depriving such entities or any of them of complete information about events and processes occurring in the community leads to a violation of the mechanism of decision-making and coordination at different levels of political governance in order to stabilize the situation in the system; functional kind of destabilization occurs in the sphere of realization of powers, plans and programs of subjects of the political system and is aimed at occurrence of possible and real results from destabilization of political activity of these subjects in society.

The criterion of political stability is the level of coherence of political interests of different social groups of society, the state and all citizens. It is characterized by quantitative and qualitative parameters that respond to deviations from the equilibrium values of the main indicators.

1 Грищенко Д.Ю. Политическая безопасность современного Российского государства: состояние и механизм обеспечения : автореф. дис... канд. полит. наук: 23.00.02. Владимир, 2008. С. 7. 
We can consider such attributes as systemic attributes of political stability; positive development dynamics; absence of exacerbation of processes; the active role of civil society in ongoing processes; predictability of evolutionary processes.

Political stability is an important dimension of social stability, which implies a state of correlation between social groups and political forces, in which none of these forces can significantly change the political system in their interests, which ensures its status quo ${ }^{2}$. This balance is maintained through a complex mechanism of internal and external links between the elements of the political system and the political system itself. Thus, in the first case it is about equilibrium of constituents of political system and interaction between its institutions, and in the second - interaction of the whole political system with other systems of society ${ }^{3}$.

Thus, the state of political stability is intended, in particular, to ensure an adequate level of political security in a society, which should be understood as the absence of severe socio-political conflicts in the society, or constant and at the same time effective actions, first of all, of political power, to minimize the destructive influence on a society of such conflicts ${ }^{4}$. It is the implementation of a prudent policy on existing conflicts, both inside and outside the system, that make it possible to strike a balance of the political system, facilitate its further development and conduct civilized dialogue between the political forces of the country, and thus ensure the stability of the state as a system.

In terms of factors affecting the state of stability, as an important qualitative characteristic of the political system, which is ensured by the well-established interconnections between all its elements, we can distinguish between objective and subjective factors. Objective factors of political stability include: the resilience of political institutions and the effectiveness of the system of separation of powers, the political culture of a society that supports the regime. To the subjective - the effectiveness and legitimacy of power in society ${ }^{5}$.

\footnotetext{
2 Яворський М. Політична стабільність: сутність та основні підходи до класифікації. Політичні науки. 2017.Vol. 3. № 1. С. 62.

${ }^{3}$ Карл Т.Л., Шмиттер Ф. Демократизация: концепты, постулаты, гипотезы. Полис. 2004. № 4. С. 11.

4 Грищенко Д.Ю. Политическая безопасность современного Российского государства: состояние и механизм обеспечения : автореф. дис... канд. полит. наук: 23.00.02. Владимир, 2008. С. 11.

${ }^{5}$ Савин С.Д. Политическая стабильность в изменяющемся обществе : автореф. дис... канд. соц. н.: 23.00.02. СПб, 2003. С. 15.
} 
Undoubtedly, the central entity in the process of ensuring political stability is the state and its institutions. The nature of political stability in a country is largely determined by the political regime that exists in it (democratic, authoritarian, etc.). And depending on this, the mechanisms that support such stability differ.

For example, authoritarian and totalitarian regimes have a peculiar stability that allows such states to maintain their integrity, even under extremely difficult conditions. At the same time, their inherent mechanisms of maintaining the state of political stability are oriented towards the formation of a closed socially homogeneous society, where the regulation of any relations is ensured by repression, violence aimed at eliminating any existing or potential opposition. Such stability is unproductive because it leads to depression and political stagnation and leads to the collapse of the political system. That is, it is about stagnant stability.

At the same time, a democratic society is an open system that is able to adapt relatively quickly to changes in the internal and external environment. Therefore, such a state is inherently dynamic and includes political pluralism and multiparty politics, where competition in the struggle for political power is realized within the framework of generally accepted democratic legislative rules. The openness of a democratic society's political system enables it to adapt relatively quickly to changes in the internal and external environment by responding swiftly, adequately and effectively to its challenges. Such stability is dynamic, it can be called alive, constructive and guaranteeing the self-reproduction of democratic regimes. Thus, the phenomenon of political stability is characterized by the existing mechanism of adaptation of the political system to the conditions of functioning of the society and its peculiarities, thus providing the most optimal conditions for the normal functioning of the political system.

It should be noted that a stable democratic state is characterized by a number of defining features: a sense of belonging to the nation by the population of that state; stability of forms of government with the simultaneous guarantee of legal change of power, which does not allow usurpation of power in one hand. In a broad sense, it is a way of replacing or transferring political power from one individual (government or regime) to other relevant actors, which helps to avoid crises and keeps the process under control; gradual and orderly rotation of ruling elites; the existence of a system of checks and balances, which ensures a balance in the power structure and prevents abuse; multiparty and effective opposition; the presence of a large middle class. 
The aforementioned factors of political stability are interrelated because instability of one of them can lead to instability of the whole country.

Important in this context is the analysis of the theory of political transit, which in its essence represents the transition of society from one state to another, namely from authoritarian or totalitarian political system of the country to democracy, and socio-economic sense - from monopolistic, isolated, controlled mainly state, economy to market economy ${ }^{6}$.

The classical theory of three «waves of democratization» by S. Huntington, which is a group of transitions from undemocratic to democratic regimes that take place over a period of time, according to which democratization is regarded as a global process, made a significant impact on the development of political transit theory ${ }^{7}$.

Democratic transit takes place over a period of time, during which the state-political system of the country and society itself undergoes fundamental transformation and dramatic changes. In addition, this process is characterized by a two-phase «stabilization / destabilization» dynamic, and for the successful completion of the transit process it is crucial that stabilization methods and means contribute to the promotion of democratic principles in the organization of social and political life.

It is important for our study to take into account the fact that there is no consensus among researchers as to where the political transit process should go. The classic view is that of democracy. However, recent researchers are no longer uniquely apprehending its ultimate goal. After all, in some countries, the population will calmly respond to changing conditions, justifying the ultimate goal of transition, and in others, quite quickly disappointment occurs in the process ${ }^{8}$, because of the collapse of illusions about democracy as a path of common prosperity, because the process of democratization is often accompanied by poverty for a large part of the population. The inability of young and not yet established democratic regimes to satisfy the economic interests of the poor will often threaten the entire democratization process.

Thus, transit processes do not always lead to the formation of a «standard» liberal democracy ${ }^{9}$, and during transit, a hybrid political regime may emerge, where democratic and authoritarian elements are closely intertwined, and the transition to consolidated democracy does not occur.

${ }^{6}$ Балаян А. Политический транзит в России: особенности и перспективы на современном этапе. 2006. URL: https://forum-msk.org/material/society/11846.html

${ }^{7}$ Демократія : Антологія / упоряд. О. Проценко. Київ: Смолоскип, 2005. С. 657.

8 Балаян А. Политический транзит в России: особенности и перспективы на современном этапе. 2006. URL: https://forum-msk.org/material/society/11846.html 
Needless to say, «democracy is more of a culture than a system of institutions ... Thus, democracy is based on the slow acquisition of tolerance and awareness of its borders: because a democratic government cannot solve all issues and appreciate its nature faster, than the results of activities that are not necessarily better in all respects than under illiberal rule» ${ }^{9}$.

All these factors lead to the great complexity of effectively ensuring the state of political stability in transit political systems in general and in Ukraine, in particular, because the ongoing processes are characterized by dynamic changes in the political system and the absence of established democratic mechanisms that would be maintained from within and reproduce themselves, and the complete absence of any guarantee of successful completion of the political transit process ${ }^{10}$.

Thus, it is necessary to turn to the consideration of the problem of the state stability as a key issue in ensuring the stability of the political system as a whole. As important forms of systemic counteraction to contemporary threats to political stability are measures to increase the resilience of the state to destructive information influence, economic and military weakening of the country, exacerbation of social contradictions in society and strategies to counter external, internal and cross-border threats ${ }^{11}$.

Increasing the stability of the state is achieved through the implementation of a system of measures and actions of state bodies, local self-government bodies and public organizations, aimed at ensuring the legitimacy of the authorities, preserving internal public, interethnic and inter-confessional peace, territorial integrity and protection of sovereignty at the national level, internal and cross-border threats.

Of course, the achievement of ideal political stability is generally utopian, since constructive political stability is not absolute. Full stability is impossible, as social development is devoid of any conflict, because they are an indispensable driving force for progress. In general, oddly enough, too high a degree of resilience of any system, including a political one, diminishes its viability. Such excessive stability may be a consequence of the hidden resistance to change by such a system. That is, the inability of the political system to adapt to change can be hidden here, which inevitably leads to the death of the system. After all, the normal political process

${ }^{9}$ Демократія : Антологія / упоряд. О. Проценко. Київ: Смолоскип, 2005. С. 16-17.

${ }_{10}$ Бокало Н., Трохимчик С. Проблеми та перспективи демократизації в країнах центрально-східної Європи (на прикладі Вишеградської четвірки). Львів: Львів. нац. ун-т ім. І.Франка, 2000. С. 48.

11 Семченков А.С. Противодействие современным угрозам политической стабильности в системе обеспечения национальной безопасности России: автореф. дис... д. полит. наук : 23.00.02. Москва. 2012. С. 24. 
includes the continuous improvement of the political system, due to its adjustment in accordance with changes occurring in all spheres of public life. And if such improvement is evolutionary, without rigid political crises, then we can assume that the political system is stable. It is this stability that should be sought as it meets the requirements of a stable and normal functioning of the system.

So let's look at the main factors and conditions that make it possible to achieve political stability in the state: the legitimacy of the political regime in the state and its legality; maintaining a high level of public confidence in the authorities through overcoming bureaucratic obstacles and corruption within the country; the ability of the political system to function effectively and respond as quickly as possible to external and internal challenges; the existence of an effective legal system in the state; guaranteeing human rights and freedoms, as well as maintaining the public's desire to participate in the political life of the country; finding the maximum balance between the norms of morality and law in society; maintaining the optimal class structure of society; prevention of acute socio-ethnic and religious conflicts within the state; effective political communication and interaction of the authorities with the people; the use by the authorities of international experience in state and political development ${ }^{12}$.

Obviously, the study of political stability is impossible without taking into account such fundamental properties of political systems as integrity, stability, dynamic equilibrium, organization, activity and informativeness. An extremely important indicator of political stability is also the ability of the system to reproduce its integrity with all its relations and relations between the elements and the fulfillment of their responsibilities. Therefore, we can attribute the system's ability to constantly rebuilding its integrity to an important feature of the phenomenon of political stability.

It should be noted that at the present stage maintaining a state of political stability, besides the influence of traditional elements (state, parties, mass media, etc.), also requires consideration of a number of other factors, processes and phenomena (transitional processes, conflicts, regional integration, new political identification political finance, party building processes, democratization, transitology and more).

12 Семченков А.С. Противодействие современным угрозам политической стабильности в системе обеспечения национальной безопасности России: автореф. дис... д. полит. наук : 23.00.02. Москва. 2012. С. 27. 


\section{Political stability and current transitive processes: the Ukrainian experience}

The use of universal postulates and schemes requires special care, as each transit country has its own specificity, which requires a careful and comprehensive analysis of national experience, which makes the process of regime transformation separate, unique and different from other systems. But in general terms, the transit processes experienced by the Ukrainian political system can obviously be included in the «third wave of democratization» by S. Huntington ${ }^{13}$, and, despite the significant differences in socio-political and economic processes, consideration of this group of countries is of some theoretical and practical interest for Ukraine: in the process of democratic transit, the states in which the establishment of democratic institutions was accompanied by the gradual formation of political and cultural values in the society are the most successful; transformations in the economic and political spheres are characterized by increased conflict and the risk of establishing hybrid regimes; democratic values are positively perceived mainly by citizens of those countries that successfully solve economic and social issues. Conversely, insufficient attention to socio-economic problems complicate the movement of states towards democratization. The unstable, unconsolidated character of the political systems formed is characteristic of those countries where economic and socio-cultural conditions were not necessary, and the process of democratization was only a consequence of the struggle for power of individual elites and political groups; there are no examples of stable democracies in states without market and private property. A market economy ensures the autonomy of the individual, protects him from total state control, stimulates the development of qualities necessary for democracy, such as the desire for freedom, responsibility, enterprise; the country's geopolitical location is extremely important for democratic change. Countries located in areas of «traditional democracy» have significant benefits and a high chance of accelerating political reform. However, the purely mechanical transfer to the countries of the «new democracies» of those methods that have played a decisive role in the democratization of the political system of the «old democracies» countries leads to the fact that in the «new democracies» countries political transit becomes variable or protracted ${ }^{14}$.

13 Хантингтон С. Третья волна. Демократизация в конце XX века. Москва: РОССПЭН, 2003. С. 57

14 Хантингтон С. Третья волна. Демократизация в конце XX века. Москва: РОССПЭН, 2003. С. 313. 
An analysis of the regional experience of democratic transit in the countries of the «third wave of democratization» shows that the rapid pace of political change is characteristic of those countries in which the processes of democratization were caused by a complex of internal and external causes, mass need and participation in these processes by the general population and which had institutional prerequisites. The unstable, unconsolidated nature of the established political regimes is inherent in those countries that did not have the necessary economic and socio-cultural conditions at the time of the beginning of democratic transformations, and the process of democratization is only a consequence of the struggle for elite power and political groups. It is also important to take into account the specificity of the Ukrainian mentality and cultural diversity with countries where transit is more rapid (for many reasons, Eastern Europe, Baltic countries), where old values and relationships are preserved while changing the whole way of life.

The position of modern countries of democratic transit to the model of «democracy with defects» (including Ukraine) is interesting) ${ }^{15}$. Political scientists V. Merkel and A. Croissant identify three varieties of «democracies with defects»: «democracy with exceptions», in which a large segment of the population is deprived of the right to participate in elections because of certain characteristics (racial, age, etc.); «Democracy with enclaves, $\gg$ in which certain spheres of public life are brought out of democratic control; «Unbalanced democracy» in which the actions of the executive are not correlated with parliament and the judiciary.

Thus, when analyzing mechanisms for maintaining political stability in Ukraine in the context of political transit, we should pay special attention to the following characteristics:

There is a marked change in the stabilization / destabilization phases for the Ukrainian political system. As noted earlier, the alternation of the «stabilization / destabilization» phases is a characteristic feature of any political transit process, where the state of political stability of the system corresponds to its antipode - the state of instability, the period of lack of balance between different elements of the political system. In Ukraine, there is a noticeable trend towards deepening and increasing the duration of the destabilization phases compared to the periods of stability. However, it should be noted that in the «stabilization / destabilization» phases of the political process, the destabilization phase is not only a threat but also a

${ }^{15}$ Covington C. Smith E. Dynamics of Democracy. Madison-Sydney: Brown\&Benchmark, 1995. P. 10. 
rather interesting time of opportunity when ineffective mechanisms operating in the political system can be detected and changed;

It is worth noting the positive orientation of the pace and scale of political transformation and reform in other areas. Ukraine has been sufficiently consistent in reforming many spheres of political, economic and social life. However, the many disadvantages of these processes cannot be ignored. So, for political and state stability, the presence of a strong middle class, which is only emerging in Ukraine, is of great importance. Also, until now, Ukraine does not have effective government instruments to protect foreign investors, which is an extremely important issue for potential investors, and therefore to ensure the financial component of political stability in Ukraine. These factors create unfavorable conditions for both domestic entrepreneurs and foreign investors;

Ukraine is characterized by the weakness of the processes of formation of democratic institutions of the political system, which is explained, in particular, by the inertia and reaction of the political elite, which does not want to abandon the use of shadow groups of influence because of fears that their rejection will lead to a general loss of positions on the political Olympics of Ukraine, decreases public confidence in government institutions and their representatives, which, in particular, effectively sabotages many political forces and electoral reform;

Let us note the significant increase in the last ten years of the level of political consciousness of the population, as well as the participation of civil society organizations in the political life of Ukraine. We can say that in this aspect today there are factors that contribute to the formation of political stability in Ukraine. It is about the activity of civil society that has begun to feel its strength, as well as the promotion of a truly democratic system by the European Union and International Financial Organizations. These factors counterbalance destabilizing mechanisms, which include considerable inertia of the institutional structure and weakness of the political will of the ruling elite;

The effectiveness of the methods aimed at ensuring political stability in Ukraine is diminished due to an inefficient, corrupt, management system characterized by a clearly insufficient level of professionalism of the judiciary, the weakness of the judicial system, which will be discussed below, the absence of guarantees of private property rights, structural and infrastructural defects, does not provide the dynamic stability necessary for the development and successful implementation of the state in the $21 \mathrm{st}$ century;

Ideological factors: many researchers point to the era of «mediaocracy» (the media authorities), who no longer reflect and interpret reality as much 
as they construct it by their own rules and discretion. And it is quite clear that the Ukrainian media are becoming a kind of weapon in the hands of the authorities, external enemies, as well as other interested parties. Media interference in politics leads to a decrease in the amount of closed information on political decision-making, including through political negotiations. The systematic acquisition of audience information about what is being discussed at interstate meetings creates a picture of the world that determines attitudes towards political figures and even states, and, consequently, the reaction to their actions. Therefore, in Ukraine, as in the whole world, the media are becoming a means of pressure, significantly reducing the effectiveness of traditional methods of conflict resolution, in particular, such as political negotiations. Today, as never before, the issue of the need for special measures is being raised, which will minimize the negative manipulative influence of the media on the political decisionmaking process. Also, the extremely difficult state of social integration of Ukraine is exacerbated by the fact that part of Ukrainian society is under the influence of another state in artificially alienated territories - illegally annexed Crimea and unrecognized republics of Eastern Ukraine. This destabilizing factor has many challenges not only for today but also for the future, the search for answers that is attracting worldwide attention;

Economic factors: today, Ukraine faces many economic problems, including, inter alia, the military conflict in Eastern Ukraine;

Foreign policy factors: external political stability includes at least four parameters: geopolitical, political, foreign economic, military-strategic. In today's world, the first place, along with geopolitical, foreign economic (geoeconomic) activity of state structures, which aims at creating adequate mechanisms for defending the interests of the national business community, supporting the competitiveness of Ukraine's national economy, including all national business, regardless of ownership and capital. What is needed is not so much a radical breakdown and complete denial of national experience as the adjustment of the course to the new realities that are constantly emerging in Ukraine.

The political stability of the Ukrainian political system is significantly influenced by the difference of interests of individuals, social groups, political actors, etc., which objectively causes conflicts of interest within the political system and, as a consequence, the presence of various conflicts and causes for their emergence and, consequently, the possibility of political disturbance of stability in society.

Based on the above methodological prerequisites, let's look at specific factors that can affect political stability in Ukraine. 
Political transit in modern Ukraine should be recognized as incomplete, as we noted, Ukraine is referred to countries with «defective democracy» ${ }^{16}$. The peculiarity of such a model is that elections as a democratic procedure are entrenched, but there is no real opportunity to exercise citizens' rights and freedoms. Therefore, in modern Ukraine, there is a need not only for the modernization of the country's legal and economic system, but also for the creation of modern effective institutions, the formation of an appropriate system of values, sustainable social practices, and it is also important to provide an evolutionary path of development, since another deep phase of destabilization may even end with the collapse of the entire political systems.

The most important characteristic of political transit in Ukraine is the increased level of conflict and the weakness of the mechanisms of their settlement, which is especially dangerous given the high level of social polarization and military conflict into which Ukraine has been involved.

At the present stage, the most important factor in Ukraine's political stability is the state mechanism of preserving the bodies and institutions of the authorities, increasing their authority in the eyes of the population, as well as the search by the existing political institutes of ways of constructively overcoming manifestations of opposition sentiments among the population of the country without bringing them to the stage of «Maidan».

Stability, in turn, does not deny the existence of a conflict field for Ukraine's political system. As we have already noted, it is impossible to avoid conflicts at all, because the human society itself is conflicting in nature, it presents many views, personalities who are drawn into political parties and public organizations representing the interests of certain sections of the population. That is why one-sided political coloring is not allowed in democratic political doctrines, and particular attention is paid to pluralism of opinions and mechanisms of compromise settlement of contradictions.

It should be emphasized that the study of democratic transit in modern Ukraine is not only theoretical, in view of the specificity of the process, but also practical, since it depends largely on the political, economic, social, cultural development of the society, the outcome of the transit in many respects are crucial for the future of the country. The political elite of Ukraine must ensure the stability of the political system by consensus, when the development of political processes is carried out without actual violence, the balanced nature of relations between the main social groups is ensured,

\footnotetext{
${ }^{16}$ Merkel W. Embedded and Defective Democracies. Democratization. 2004. Vol. 11. № 5. P. 48 .
} 
the level of equilibrium is acceptable and the civilized forms of dialogue of the political forces of the country are used in the context of political transit.

\section{CONCLUSIONS}

Thus, it can be argued that the processes taking place in Ukraine today are complex and ambiguous in nature. The stability of our country's political system under transit conditions should be considered in direct connection with the stability of the whole country as a whole and the mechanisms for ensuring such stability that the state has. It is important to take into account the ambiguous events of recent years that indicate a serious threat not only to political stability in Ukraine in terms of political transit, but also to the Ukrainian statehood itself. From where political transit takes us, the nature of change in all spheres of the country's political and socio-economic system depends to a large extent. This does not mean that political transit will not happen, just the outcome may be far from democracy.

It is determined that the political system of Ukraine plays a significant role among the entities providing political stability, which are held by state and local self-government bodies, as they provide mechanisms for supporting political development in the country, and act as legitimate state authorities. An effective mechanism for ensuring political stability should include political and party pluralism, where there is competition between actors in the struggle for political power. The trajectory of European development and the relevant mechanisms for ensuring political stability may become elements of a mechanism that supports political stability in Ukraine.

Contemporary Ukraine is in dire need of new approaches to ensure effectively political stability, which naturally attracts the attention of scientists, politicians and statesmen. Studying and identifying mechanisms that can support political stability in our country has become of paramount importance. In today's Ukraine, the nature of political stability or instability is determined by socio-economic and ideological conflicts, both in society and in the elite environment, and the reasons for this are the ineffectiveness of lawmaking. This is due both to the use of the imperfection of legislation for selfish purposes and to the lack of political will to carry out democratic reforms and to form narrow group interests in business and political groups.

Today, Ukrainian society has undergone a major transformation of its basic political values, which has led to its transition from a totalitarian system of government to a regime of democracy. Then a new wave of crisis phenomena, ethical and moral problems emerged, political struggle intensified. Obviously, the main task of civil society development in Ukraine 
is to ensure constitutional norms and legal regulation that contribute to the emergence of political stability.

\section{SUMMARY}

The article deals with the phenomenon of political stability in transitional political systems. It is determined that political stability should be understood as the stability of the political system, which expresses the fundamental interests of the main social groups and ensures the sociopolitical stability of society and the absence of acute social and political conflicts in it. Political stability implies a dynamic, evolutionary, stable and continuous on the basic characteristics when the development of political processes is carried out without actual violence, there is an adequate form of power conversion (from state to society and back), balanced relations are maintained both within the elite and the elite with other social groups, as well as an acceptable level of balance and civilized forms of dialogue between the political forces of the country. Undoubtedly, the fundamental condition for ensuring political stability in Ukraine is the end of the armed conflict, the return of the captured territories and the achievement of peace and social stability in the country.

\section{REFERENCES}

1. Балаян А. Политический транзит в России: особенности и перспективы на современном этапе. 2006. URL: https://forummsk.org/material/society/11846.html

2. Бокало Н., Трохимчик С. Проблеми та перспективи демократизації в країнах центрально-східної Свропи (на прикладі Вишеградської четвірки). Львів: Львів. нац. ун-т ім. І.Франка, 2000. 68 с.

3. Грищенко Д.Ю. Политическая безопасность современного Российского государства: состояние и механизм обеспечения : автореф. дис... канд. полит. н.: 23.00.02. Владимир, 2008. 26 с.

4. Демократія : Антологія / упоряд. О. Проценко. Київ: Смолоскип, 2005. $1108 \mathrm{c}$.

5. Карл Т.Л., Шмиттер Ф. Демократизация: концепты, постулаты, гипотезы. Полис. 2004. №4. С. 11-14.

6. Кіянка І. Б. Політична стабільність: суть і основні засоби iii досягнення в Україні : автореф. дис. ... канд. політ. наук: 23.00.02. Львів, 2003. $18 \mathrm{c}$.

7. Латигіна Н. А. Демократія : реалії versus утопії. Київ: Київ. нац. торг.-екон. ун-т, 2008. 400 с. 
8. Савин С.Д. Политическая стабильность в изменяющемся обществе : автореф. дис... канд. соц. н.: 23.00.02. СПб, 2003. 29 с.

9. Семченков А.С. Противодействие современным угрозам политической стабильности в системе обеспечения национальной безопасности России: автореф. дис... д. полит. наук : 23.00.02. Москва. 2012. $50 \mathrm{c}$.

10. Хантингтон С. Третья волна. Демократизация в конце XX века. Москва: РОССПЭН, 2003. 368 с.

11. Шмиттер Ф. К. Будущее демократии : можно ли рассматривать ее через призму масштаба. Логос. 2004. № 2. С. 137-156.

12. Яворський М. Політична стабільність: сутність та основні підходи до класифікації. Політичні науки. 2017.Vol. 3. № 1. С. 61-66.

13. Covington C. Smith E. Dynamics of Democracy. Madison-Sydney: Brown\&Benchmark, 1995.

14. Merkel W. Embedded and Defective Democracies. Democratization. 2004. Vol. 11. № 5. P. 48-49.

\section{Information about the author: Kozminykh A. V.,} $\mathrm{PhD}$ in Political Science, Associate Professor, Associate Professor at the Department of Political Theories of the National University «Odessa Law Academy» 2, Academichna str., Odesa, 65009, Ukriane 
DOI https://doi.org/10.36059/978-966-397-158-2/191-208

\section{TRANSFORMATION OF POLITICAL CULTURE IN THE SOCIO-CULTURAL CONTEXT OF UKRAINE}

\section{Sushko A. I.}

\section{INTRODUCTION}

Transformational changes occurring in Ukraine at the turn of the XXXXI centuries significantly affect political and socio-cultural processes. Democratization of society, formation and realization of new cultural and spiritual values testify to the establishment of Ukraine as a unique local civilization. It is in this context that the place of our country in the European and global world space should be determined. The study of political culture becomes more relevant from the standpoint of combining the best examples of the European Union's cultural standards on the one hand, and the preserved and enhanced spiritual values and national traditions on the other.

In order to analyze the processes of functioning of the political culture of our society in the historical understanding of the specifics of its formation, the author considers that special attention should be paid to the possibilities of socio-cultural approach. Carrying out such an analysis of various phenomena of manifestation of political culture allows to expand considerably the subject field of its research and on this basis to comprehend the most effective models of political culture, which have historically been formed, which correspond to modern needs of both citizens and society as a whole.

Foreign and national science in recent decades has been enriched by a large number of works that take into account various aspects of the development of political culture in the modern civilization. At the time, a number of issues need further attention. Thus, the features of the formation of political culture of the Ukrainian people under the influence of internal and external factors are underdeveloped, which led to a change in the forms of manifestation of political culture, the peculiarity of its evolution in the context of the civilizational choice of Ukraine.

The study of this problem is based on the use of classic methodological tools - systematicity, historicism and objectivity. This allows us to investigate thoroughly the dialectic of socio-cultural processes within which the formation of political culture of our people was. The author prefers a 
civilizational approach in the analysis of the peculiarities of the historical process, which allows, first, to more fully reveal the interaction of political culture with the mentality, spirituality, and secondly, to embed organically this complex process as an integral part of the European civilization paradigm. In this way the pattern and tendency of the development of the identity of the political culture of the nation are revealed, which allows to overcome the crisis phenomena in the socio-cultural processes of modern Ukraine more effectively.

\section{Understanding the historical processes of transformation of political culture}

A positive factor in the development of theoretical construction is the understanding of the concept of «political culture» in the broad sense. The authors of this approach include in its composition both the basic elements and the formed political traditions, norms of socio-political activity, ideas, concepts and beliefs concerning the interaction of political institutions of the state and society. Within this framework, political culture is defined from the standpoint of the characteristics of qualitative traits of different social actors in the sphere of political relations. In essence, all supporters of this approach emphasize the long absence in the political field of Ukraine the activities of democratic institutions and, consequently, the inability to shape fully the modern political culture.

In developed democracies, civil society has a role in transforming political culture. It significantly influences the activity of the authorities and the state administration and through the existing political and legal model of interaction the process of becoming a democratic type of political consciousness is underway; the political behavior of an active citizen is formed. Such a variant receives the necessary stability only in stages and with the condition of entering into real political activity of the majority of citizens, representing all social groups of a given society. It is being implemented more effectively, and, most importantly, new institutions are operating, the search terms for finding a way out of the crisis are shortening, civilizational landmarks are coming into force more quickly.

It is important that the socio-cultural approach allows us to comprehend more adequately contemporary socio-political realities, in particular, to disassociate from the one-sided vision of the political system and its institutions - firstly, and secondly - the political culture itself is seen as a characteristic of the full realization of all the essential possibilities of the sub political relations. Therefore, more and more attention is being paid to the analysis of the interpretation of the concept of «sociocultural» within the 
dominant tendency of modern humanities to consider human activity in the cultural dimension. Various problems of socio-cultural identity, sociocultural world of Ukraine are revealed in the works of L. Males, A. Sokuryansky, M. Yurii ${ }^{1}$. It is also worth noting the works directly devoted to the civilization understanding of the culture of Ukraine. First of all, it is the groundwork of L. Hubernsky, V. Andrushchenko, Y. Kalakura, M. Mikhalchenko, O. Rafalsky and V. Sheiko².

The authors of these and other works view the theory of civilizations as a more universal paradigm, which qualitatively blends with the sociocultural view of history, compared to the formative approach that dominated sociopolitical analysis by the end of the twentieth century. A new look at the factor of culture in collective self-identification is gradually changing the priority of the economic basis, which, in the opinion of the proponents of the traditional approach, was decisive in characterizing the functioning of any society at all stages of its development. Of course, the problem of cultural resources, the ability to dispose adequately of them is quite a multifaceted and ambiguous problem. Her new understanding is seen as a field of multiplicity, differences, gaps in historical development. «Culture is a manifestation of a person's interpretive subjectivity in relation to himself and his world. It is simply identical to the mental process of delivering or creating content without which human life would be impossible». ${ }^{3}$ Thus, according to the opinion of L. Nagorna, «the focus of the analysis is there, and this is where the ethos is - the space of values, the ideal objects that outline the circle of priority representations of man. It is the values that lay the spiritual-orientation foundation of social life, which is equally interesting to historians and political scientists».. ${ }^{3}$ The author emphasizes that the reflexive potential of historical culture evaluates, first and foremost, its socio-cultural space - with a set of values and meanings circulating in it, and political forces, as a rule, adversely affect the state of socio-cultural reflection, creating a delineation of levels of strategy and tactic. It is permissible to say, the author thinks, even about the existence of different

\footnotetext{
${ }^{1}$ Малес Л. Розуміючий потенціал соціокультурного аналізу //Якісні дослідження в соціологічних практиках. Навч. посібник. К, 2009. С. 77-95.

Юрій М. Ф. Соціокультурний світ України: Моногр. 2-е вид. К.: Кондор, 2004 С. 736.

2 Губернський Л., Андрущенко В., Калакура Я., Михальченко М. Ідеологія, особистість, методолого-світоглядний аналіз. К.: Знання України, 2002. 580 с..; Калакура Я., Рафальський О., Юрій М. Українська культура: цивілізаційний вимір. К.: ІПіЕНД ім. І. Ф. Кураса НАН України, 2015. 496 с.; Шейко В. Культура України в глобально-цивілізаційному вимірі (історико-методологічні аспекти). К.: Інститут культурології НАМ України, 2011. 624 с.
} 
historical subcultures in Ukraine, subordinated to different political goals and oriented towards opposite cultural patterns. ${ }^{3}$

In the post-socialist space, Ukraine is one of the countries with the longest transit, in addition, with deviations in movement. In fact, our country is in the midst of a consolidated democracy and a semi-authoritarian regime. According to the opinion of the most researchers, transit is a concept that refers to changes in the political regime and has a beginning and an end. Sometimes it is interpreted as a synonym for transformation, or transition, that is, it depends on the meaning put into these concepts by various authors.

Transformation, as a concept, is used in relation to objects with complex structures that have changed significantly, and as a rule, for the better. The trajectory of socio-political transformations in Ukraine has a long period and, at certain intervals, is less definite in comparison with the countries in which transit has ended with the consolidation of democracy.

Within the framework of socio-humanitarian knowledge, the process of historical discourse is increasingly viewed in a cultural context. The imperative of time is contextuality - the need to study any historical phenomenon in the context of the sociocultural environment that gave birth to it. Modern epistemology strongly rejects the search for universal theoretical constructs that are suitable for analyzing the history of different times and peoples, says A. Nagorna. It is only through the cultural context in which it is destined to exist that one can understand the way of thinking of the person of the past and the framework of his «life world». ${ }^{4}$ Therefore, it is natural for skeptics to be able to create a common theory of socio-cultural evolution and optimistic about the prospect of a comparative analysis of cultural traditions, separated from each other by millennia ${ }^{5}$.

In general, historical memory is quite functional and has its own cycles in different socio-historical conditions. Thus, the transformation processes of the late and XVII and XX centuries increased the interest in our own historical past, as a result, the consciousness of society increased.

It is not the formational but the civilizational approach that is most successfully combined with socio-cultural history. Although its methodology requires further development, the achievements of this approach allow revealing more fully the originality of national cultures, including the Ukrainian one. A political approach that will reveal the influence of the

${ }^{3}$ Нагорна А. Історична культура: концепт, інформаційний ресурс, рефлексивний потенціал. К.: ІПіЕНД ім.І.Ф.Кураса НАН України, 2014. С. 53-56.

${ }^{4}$ Нагорна А. Історична культура: концепт, інформаційний ресурс, рефлексивний потенціал. К.: ІПіЕНД ім.І.Ф.Кураса НАН України, 2014. С. 116

${ }^{5}$ ibid C. 117. 
political systems of Kyiv Rus, Galicia-Volhynia principality and the Cossack-Hetman state, as well as the cultural process and profound changes in the mentality of Ukrainians, their way of life and worldview, should also be considered promising.

The interaction of political and cultural processes is especially relevant during periods of instability at bifurcation points. For Ukraine, these are structural displacements and their disintegration, changes «centerperiphery». In the context of the synergistic approach, transitions become the field of study of the problem of historical alternatives, the possibilities of changing the vector of development, the combination of traditions and modernizations.

In today's context, the scientific discourse of marked research is becoming the focus of humanitarian thought in Ukraine. The phenomenon of borderlands, which O. Kryvitska points out, is that in the space of its interaction new forms of solidarity of social communities are emerging, socalled, transformational social networks are being formed. In the border areas there are processes of layers of different socio-cultural markers, which affects their «privileged» status, provides the opportunity for various communications. The boundary of an element of spatial organization is transformed into factors of influence, providing a new quality of development of the border socio-cultural and mental space ${ }^{6}$. It is here as in the most intense areas of the cultural space that the choice of a further life strategy of a person is made. Overall, the intense functioning of the crossborder region generates a kind of culture.

Research into the historical competition of different strategies - settled agriculture and nomadic in forest-steppe zones - has started quite intensively. Dominance has shifted from one side to the other within a certain field of ethnic unity. Controversial in this context is L. Gumilev's statement about the combination of Desh-i-Kipchak and Kyiv Rus in one multi-ethnic state (XII-XIII centuries) ${ }^{7}$. Even more controversial is the position of another author (M. Aji) on the Turkish character of Kyiv and Ukraine $^{8}$. More justified is the picture of showing the victory of agricultural culture from the standpoint of civilization approach. Of course, a significant segment of the nomadic world has entered a new whole. This process

\footnotetext{
${ }^{6}$ Кривицька. О. Дискурс пограниччя в соціокультурних дослідженнях: теоретичнометодологічні аспекти. Наукові записки: ІПЕНДім. І. Ф. Кураса НАН Украӥни. - 2015 Вип. 4(78). С. 173-174.

${ }^{7}$ Гумилев Л. Н. Древняя Русь и Великая Степь. М.: Товарищество «Клышников Комаров и К», 1992. С. 327.

8 Аджи М. Европа, Тюрки, Великая Степь. М.: ООО «Издательство АСТ», 2004. C. 67-80.
} 
stretched across time and space, and the Cossack community was born in the buffer strip. As each transition form, it disappears over time.

As a segment of socio-cultural history we can also consider the mentality of certain social groups, which most fully reflects the picture of the world of different stages of development of our society. In this context, mentality is seen as a historical phenomenon, that is, it embodies a certain level of social and individual consciousness, the associated spectrum of culture and behaviors as the inheritance of certain ethnogenetic memory. The historical problems of mentality, in particular the sources and archetypes of the Ukrainian mentality, considered in the collective monograph by M. Popovych are quite thorough ${ }^{9}$. He and other well-known scientists (S. Krymsky, M. Mikhalchenko, Y. Pavlenko) hold the opinion that Ukrainian society has always belonged to a larger system than the country and has its history and structure of many elements.

The problems of assimilation and acculturation, intercultural interaction and synthesis are becoming more relevant and debatable. And if for a long time they have been paying attention to the processes of assimilation, which leads to the loss of their own cultural specificity of certain social groups (princes, Ukrainian nobility), then the modern researchers shift the emphasis to the study of permanent acculturation, which forms a border culture. They are defined by multiculturalism, the appearance of a marginal person - a kind of «cultural hybrid». Being a process of mutual influence of cultures, the perception by one ethnos of the culture of another, acculturation also promotes marginal forms, often condemning people to exist in several cultural worlds at the same time. Such individuals are celebrated or, by bilingualism, have more independent views and a broader choice, or a negative process of subordination to a dominant group of society, which in most cases marginalizes a person, causes a sense of social dichotomy, bifurcation. The third variant has also been actively studied, when the sociocultural environment of the cross-border region is a realm where two cultures intertwine and where a space-absorbing culture combines and integrates the features of two cultures. And at the center of this encounter is a marginal man struggling to be a key figure between the two lights ${ }^{10}$.

${ }^{9}$ Проблеми теорії ментальності / Ред. М.В. Попович . К., Науккова думка, 2006. 404 с.

${ }^{10}$ Калакура Я., Рафальський О., Юрій М. Українська культура: цивілізаційний вимір. К.: ІПіЕНД ім. І. Ф. Кураса НАН України, 2015. 496 с.; Шейко В. Культура України в глобально-цивілізаційному вимірі (історико-методологічні аспекти). К.: Інститут культурології НАМ України, 2011. С. 280. 
Worldview is a broad concept, but less related to adaptive elements, so it is better to use the term «world picture». Different social groups within the domestic culture in the same period had different pictures of the world.

Being a fundamental pillar of human existence, the picture of the world reflects the connections of man with the world, which objectively exist in practice, and it fixes those transformations that are productive in nature. The core of the picture of the world is formed by socio-cultural constants, which essentially make up the system of rules of perception, thinking, action. At the same time, the external environment significantly influences them and thus creates the conditions for new manifestations of human behavior. In the history of different socio-cultural communities, previous orientations have been displaced to the periphery of the world picture and exist in a latent form.

The process of becoming a Ukrainian nation took place in different socio-cultural coordinates, and the states that owned Ukrainian lands in the XIII - XVII centuries were politically and even civilly quite different. Some were based on the principles of despotism, while others had representative government bodies. Due to the heterogeneity, different ethnic groups developed in cultural settings, which differed significantly from each other, and this affected political culture.

Not having state support, the Ukrainian ethnic group in the process of acculturation got into a situation of crisis of its own identity, which is especially characteristic for the elitist part of society. After coming under the rule of the Grand Duchy of Lithuania, there was no own center of concentration of the elite. The process of study in European cities made it possible to get acquainted with the social achievements and legal institutions of the West, which contrasted sharply with the samples of their own ethnicity. The inferiority complex was also facilitated by the name «Mala Rus», which appeared in the XIV century and spread again in the XVII century on church and political spheres. In the XVIII century the name «Malorosia», made of the name «Mala Rosia», only concerned the Hetmanate, where the Malorosia identity was formed. At the end of the century, this process was suppressed by the efforts of the imperial center.

The idea of free people who have chosen a military destiny and serve nationals is based on the cultural model of Zaporozhian Cossacks. Formed in the fronts of the agricultural and nomadic worlds, the Cossacks were able to create a unified system with other lands, and their culture was perceived as part of the Ukrainian tradition. This made it possible to take a leading role in establishing their own statehood, to form an administrative and political system throughout Ukraine, which has long operated on the Left Bank. Thus, 
being the creator of new values and ideals, the Cossacks spread them to all regions of Ukraine. The authors of political treatises of the Hetman era were aware of the continuity with previous eras of the statehood of their people. It did not matter in the future for the development of the social-state idea of Ukrainians ${ }^{11}$.

It can be stated that significant socio-cultural changes of the XVIXVII centuries. In general, they were in line with pan-European processes, including state-building, moreover, Ukrainian society was directly involved in them. Social and religious conflicts at the turn of the Middle Ages and Modern times were quite long and bloody all over Europe and Ukraine is no exception here. Therefore, fundamental trends in Ukrainian society, represented by Orthodox fraternities, militant anti-Catholic polemicists, and grassroots social movements, whose political leader was often Zaporozhian Sich, became uncompromising ${ }^{12}$. But, in these extremely difficult conditions, it is Cossacks who, to a great extent, owe it to the selfpreservation of the identity of the Ukrainian nation.

Ideas of humanism and the Renaissance, the myth of the Great Sarmatia, which became the epitome of the Polish-Lithuanian Commonwealth as an outpost of Christianity, were popular among the Ukrainian elite. The nobility's liberties found support in Russia-Ukraine and in some way contributed to the creation of their own historical and political identity. In the writings of humanists of Ukrainian origin, the awareness of equal partners with the Poles is clearly expressed. There are various projects of restoring the statehood of Rus within the framework of the Commonwealth (S. Orikovsky, I. Dombrovsky, K. Sakovych). In particular, such ideas became relevant in the search for a common identity of Galicia, Podillya, Volyn and Kyiv region, when these lands were in the same state after the Union of Lublin (1569). The complexity was, first, in the spiritual-religious conflict of the turn of the XVI - XVII centuries, and secondly, in the absence of real experience of political management in the Ukrainian nobility, which did not allow it to become a dominant political force in Ukrainian society. Its place was taken by the new Cossack-born elite, who embarked on a path to electing political rights by armed means ${ }^{13}$.

National liberation movements of the XVII century clearly demonstrated the process of formation of an early-modern national community, the

${ }^{11}$ Іванченко Р. П. Історія без міфів: бесіди з історії української державності : навч. посіб. 2-ге вид., переробл. і допов. К.: МАУП, 2006. С. 211.

12 Юрій М. Ф. Соціокультурний світ України: Моногр. 2-е вид. К.: Кондор, 2004. C. 296 .

${ }^{13}$ Шевченко Н.В. «Ягелонська спадщина» у світлі сучасних українських історичних студій. Історичний архів. Миколаїв, 2008. Т. 1. С. 34-35. 
concept of Ukraine as a mother country, the beginning of their own statehood.

Ethnic and then national consciousness is a central component of the mentality of all sociocultural entities and individuals.

The Enlightenment period in Ukraine contributed to the creation of a more open-ended culture, in which several independent zones coexisted, with each other being primarily sacred and secular. They had different languages of use, but there was no rigid demarcation and legal boundaries. Often, authors move freely from one language to another, depending on the purpose of the work. Being in different socio-cultural situations formed by the interaction of the Catholic and Orthodox worlds, which supported respectively the Commonwealth and the Russian Empire, Ukrainian culture was able to use this situation to form many mixed forms. This did not preclude discussions and the emergence of new forms of national liberation movement.

The continuation of the traditions of the Middle Ages in the sacral zone was especially clearly manifested in the system of education, the arts, above all, in icon painting, chronicle, and teacher literature. The new baroque aesthetics allowed religious values to be developed on a new basis without negating traditions. Thus, in baroque forms of religious poetry, the secular was combined with the sacred, which had not been the case before. In this way, the synthesis of styles gave rise to new phenomena becoming a sign of Ukrainian culture of modern times, as well as the constant fluctuations of many authors between the archaic of the Middle Ages and the new Baroque forms. Moreover, there were different levels of baroque and this allowed recreating the reality, to break the line between «high» and «low» themes, and most importantly to change the opposition of the sacred and secular to their rather peaceful coexistence.

More and more scholars are linking the time of nation birth in Europe to the first translations of the Bible into national languages. Printing in the four Gospels in ancient Ukrainian literary language helped to establish ethnic identity. According to the concept of B. Anderson in the XVII century, the emergence of national histories and printed educational literature more intensively accelerate the national consciousness, which shape the perception of each people about themselves, its mission in the world - the national idea.

Thus, according to the author, these factors began to influence the basic ethnic characteristics of Ukrainians, updating their mentality and subsequently, to determine the peculiarities of the political culture close to the values of the European world. 


\section{Sociocultural factor of the national creation process in Ukraine in the XIX - beginning of the XX centuries}

Researchers on issues of national relations emphasize the speed of emergence of national communities as the foundation of socio-cultural ties in the modern times.

Specific to this approach is Ya. Gritsak's research on the process of natiogenesis. He considers the time of the appearance of the "early-modern» Ukrainian nation of the XVI-XVII centuries, and the modern - the XIXXXI centuries. ${ }^{14}$ In the second half of the XIX century the process of politicization of the Ukrainian society based on the national idea begins. This period was a turning point for a new era - the Modern Age, when political nations and their political unions are dominant. Political becomes a national movement and peoples without a state. In this concept, the Ukrainian national movement was born on the basis of cultural and linguistic requirements, and in the XX century. It is clearly politicized, especially in the Austro-Hungarian Empire. This process contributes to the growth of political consciousness of Ukrainians.

During the XIX century the birth of a modern Ukrainian nation is taking place, which has led to the emergence of nationalism. During this period he went through a 3 phase self-development: the cultural interests of the intelligentsia; the ethnic, national identity of the intellectual elite of Ukrainian society; and at the end of the nineteenth century, it is framed into an ideology and political movement whose task was typical of nationalism in Eastern Europe - to transform the masses into a nation. Ideological and political design of Ukrainian nationalism at the turn of the 19th-20th centuries. powerful social factors also provoked ${ }^{15}$.

According to a research report prepared on the basis of a survey of 58 Ukrainian and foreign experts, the main source of significant problems of modern Ukrainian society is the lack of a national idea and common identity. «The crisis of trying to unite the quite different national conceptualizations existing in modern Ukraine leads to the lack of a clear vision of the desired end results of social transformations, the slowing of the latter and the deepening of economic decline» ${ }^{16}$.

${ }^{14}$ Грицак Я. Нариси історій України. Формування модерної української нації XIXХХ століть. К.: Генеза,1998. 279 с.

15 Касьянов Г. В. Український націоналізм: проблема наукового переосмислення. Украӥнський історичний журнал. 1998. № 2. С. 48.

${ }^{16}$ Резнік В. Теоретико-методологічні семінари в Інституті соціології НАН України. Соиіологія: теорія, методи,маркетинг. 2013. № 3. С. 182. 
The answer to the causes of such phenomena should be sought not only in social processes sufficiently enlightened by our scientists, but above all in the socio-cultural aspects of life, especially in the period of modernization. Thus, the deployment of industrialization, urbanization, general education, which constitute the essence of this phenomenon, in the territory of the Russian and Austro-Hungarian empires, despite some dynamics, were insufficient and delayed in comparison with most European countries. In essence, modernity has shaped modern Europe as a post-traditional society, dominated by individualism and the dynamism of the social system, primarily by increasing its influence on the intellectual and cultural sphere. Transformation in Ukrainian society of the XIX century under the influence of the spiritual values of modernism allows us to understand the essence of our modern life, tendencies and processes of socio-cultural development of Ukraine.

National processes are particularly controversial in traditional societies when marginalization becomes a dominant trend in crisis social systems. It proceeds in the form of a subculture of transitivity, with specific interests and values, patterns of behavior in different spheres of life ${ }^{17}$.

The abolition of the institution of the Hetmanate is a time-consuming process and finally ends in the 30's of the XIX century. This process, in fact, ended with the prospect of developing a little Russian identity, showed the impossibility of forming on this basis a self-aware political nation. «Instead of developing into a modern Malorosian national consciousness, Malorosian identity went the way of the strange Landespatriotismus, who planned the decline of the Malorosian nation.»18.

Essentially, the sociocultural self-identification of the Malorosians worked for regionalism, the allocation of local identity to the religion of service to the Russian Empire. Positive in this process were the search for cultural sources, determination of the peculiarities of the character of native Russian culture, their folklore, everyday life, and language, which in the future helped the new stage of the already Ukrainian revival and national liberation movement. It should be agreed that Russians as a whole were part of the historical process of developing the consciousness of the elite in the role of state institutions of Russia and foreign cultural domination. But it's not just about integrating Ukraine into the imperial space. Other factors that have encompassed a broad socio-cultural condition that integrate elements of integration and marginalization should be highlighted.

${ }^{17}$ Радзієвський В. Базові резонансні субкультури сучасної України: монографія. К.: Логос. 2014. С. 220-221.

${ }^{18}$ Когут 3. Російський централізм і українська автономія: Ліквідація Гетьманщини, 1760-1830. К.: Основи, 1996. С. 187. 
The crisis of traditional values also gives rise to various kinds of marginalized existence with its forms of social impatience, denial of existing social institutions. Margins are the social base of terrorism, incl. and revolutionary, especially when their social value system extends to other social groups and becomes the basis of political upheavals and revolutions.

This connection is well grounded in the monograph of V. Volkovinsky and I. Ikonikova, incl. peculiarities of the terrorist movement of Ukrainians ${ }^{19}$. Authors of such works are increasingly revealing the influence of ideology and activity of terrorist groups of different directions on sociocultural processes in Ukraine. At the same time, he is still waiting for his analysis of the issue of the features of political terrorism in the Ukrainian national liberation movement, its ethical justification and moral evaluations.

Unlike the Russians, the Ukrainians were formed in other socio-cultural coordinates. Kyiv Rus was part of the European civilization community. Grand Duchy of Lithuania, Commonwealth of Poland closely related to Western European cultural values. The new era politically united Ukrainians and Russians within a single state. The center of the union is faith, in other aspects it is difference, and so the empire began to erase it by assimilation. Among other consequences, this caused some amorphism in the sociopolitical and cultural activities of Ukrainians who lived in the Russian Empire, unlike the part under the rule of Austria-Hungary. It is only natural that some Ukrainians saw only the abuser in the state, and the Cossack Mamay became the ideal of life. This gave rise to a mass movement of anarchism led by Nestor Makhno.

In the political culture of Ukrainians, the view of violence as a duty is an attribute of power to which it is itself legitimized. Even in the regions of Ukraine where people have traditionally sought freedom, they have been hiding from harassment by the authorities. For a long time there was no real state power, which was usually not its own, in the South-East of Ukraine. Leadership functions were performed by local chieftains. Individual freedom was more important than in other regions of Ukraine and not in comparison with the values of the population of other regions of the Russian Empire. Conquering such people is the most effective force of terror possible. It should be noted another negative feature of the carriers of this mentality, which, in particular, emphasized E. Fromm: «This, at first glance, their independence seems to be like the inner strength and integrity pushing them to fight and any force that limits their freedom ... It is an attempt to assert themselves, to overcome the feeling of their own powerlessness, but a dream to obey, conscious or not, when this is preserved $\rangle^{20}$. This socio-cultural

19 Волковинський В., Іконікова І. Революційний тероризм в Російській імперії і Україна(ІІЦ пол. ХІХ - початок XX ст.). К.: Старий світ, 2006. 416 с.

${ }^{20}$ Фром Э. Бегство от свободы. Тайна порока. Харьков: Эдис, 1995. С. 168. 
peculiarity of a part of the Ukrainian society gives arguments to attribute Ukraine to the limit, which is, first of all, high level of conflict, feeling of peripherality, discomfort related to blocking of partisipation experience ${ }^{21}$. Addition to this position on limitroph as a zone of contact between local civilizations of steel and the assertion of the inevitability of this atmosphere of Manichean structures and the corresponding cultural worldview and outlook, which leads to the split of cultural consciousness. Therefore, «two programs of reproduction of the socio-cultural whole live and constantly update themselves in Ukrainian culture, which mutually disable one another. It is important to realize, - the authors emphasize, - that the split is happening through the consciousness of the native Ukrainian culture. Hence - the severity and lack of integration of the personal field, a number of instant inertial transitions and much more» ${ }^{22}$.

The author considers that such phenomena should be more constructively considered within the concept of postmodernity as a new cultural paradigm and interpreted as a special type of world view oriented towards the following values: freedom in everything, rejection of priorities, complete spontaneity in the activity of the individual, above all the artist. And, importantly, it should be used to analyze any period in the history of our socio-cultural development. Postmodernism is not just a modern methodology of sociocultural knowledge, but is a characteristic of social reality in which the attitude to chaos is a kind of order ${ }^{23}$.

It is clear that the epochal socio-cultural transformations that took place at the turn of New and Modern Times also caused crisis phenomena, which take on various forms of manifestation. The need for their analysis and rethinking is conditioned by the likelihood of their recurrence in our times when Ukrainian society has signs of a crisis society. It is promising to analyze the peculiarities of interaction in this situation of personality and nation. At the turn of XIX-XX centuries, processes of industrialization destroyed the structures of the traditional agrarian society, in which the dominant factor was the community and family, not individuals. The process of national formation itself was impossible without replenishment of the nation by individuals. The concept of the nation as an imaginary community of B. Anderson fully discloses this process. Leaders of national cultural movements developed sufficiently substantiated concepts of the nation and disseminated it through the system of education, literature and brought under

${ }^{21}$ Андрущенко В. Соціальна філософія: історія, теорія, методика. К.: Генеза, 2006. C. 624-627.

${ }^{22}$ Калакура Я., Рафальський О., Юрій М. Українська культура: цивілізаційний вимір. К.: ІПіЕНД ім. І. Ф. Кураса НАН України, 2015. С. 398-399.

23 Уварова Т. Постмодернізм як нова парадигма української культури. Аркадія. Культурологічний та мистечттвознавчий журнал. 2009. № 2(24). С. 13 
it a solid historical base. The most extensive scientific research was presented in the History of Russians, when the beginnings of the Ukrainians were associated with the Sarmatians, and later the concept of direct origin of Trypillians appeared. These and other scientific developments represented national formation as a long process, during which ethnic characteristics were formed, which became decisive at the final stage. In this context, constructivist and ethnocultural approaches have been combined whereby the freedom of self-determination of individuals and nations is an interconnected process and the rights of the individual must be upheld by the concept of national rights. From these points of view, nation-building can be seen as a response of the Ukrainian people to political-assimilation, further accelerating the collapse of political empires in the early twentieth century.

The socio-cultural specificity of Ukraine is also in the relationship of different ethnic groups, especially with regard to Russians and Poles. So armed speeches of Poles of 1830-1831 and 1863-1864 took place in RightBank Ukraine and influenced the relations of representatives of these ethnic groups. The repression of the tsarist authorities against the insurgents was quite widespread, but there was no doubt in their status as a national minority. At the same time, Russification of the region is increasing. Thus, the Ukrainians were not denied the formal equality of individuals, but were not recognized as a separate national community. On the territory of AustriaHungary, the Ukrainian population had certain rights, but they were largely offset by the position of Polish citizenship, which was the main opponent of granting political rights and freedoms to Ukrainians. At the beginning of the twentieth century, this conflict of political elites has grown into a confrontation between peoples, which is gaining ground ${ }^{24}$. This situation, on the other hand, contributed to the growth of national consciousness and the radicalization of national movements of both Ukrainians and Poles. We also feel its consequences in the current context of the relations between the two peoples, especially regarding the historical past.

At the heart of civilizational knowledge of political culture should be placed such a category as the «picture of the world», i.e. the system of ideas, a set of knowledge and views on the surrounding world and its structure. Typically, this category performs an orientation function in the knowledge of human activity. Specifying the problems, it should be noted that in these circumstances the tradition of independent existence of Ukrainians in the political field from Russia and Poland is realized. It is clear that not everyone in these countries agrees with such approaches, but for us this means self-denial of our own history and national identity.

Thus, within the framework of modernity, profound socio-cultural changes are taking place in Ukraine, which have markedly influenced the

${ }^{24}$ Субтельний О. Україна: історія. К.: Либідь, 1991. С. 290. 
character of people's thinking. The more traditional positivist worldview of the XIX century was replaced by modernism. He paid attention to the spiritual values and life practices of people who have been marginalized the notion of race, people, life, etc. Moreover, the usual notions were filled with other content within the philosophy of culture. The process of human life on the basis of systematic, orderly, ethics of modest work and philosophy of small affairs was changed by the destruction of the routine of human life. Its place was taken by the energy of impulse, the creative life of the individual not bound by duties and responsibilities. This approach actively penetrated into the sphere of political culture, where the notion of freedom of creativity of the individual, independence from everyday life, and superficial attitude towards everyday life occupy an increasingly prominent place. Life was thought of as a value filled with struggle, creativity, embodiment of utopian ideals. Of course, this was a protest against the then lifestyle based on calculation and practicalism, against the subjection of human rigid standards of behavior. But, an approach to the formation of a special type of individual that will assert a new way of life, including totalitarianism of the twentieth century, is unambiguously formed in its various versions, because modernism is also characterized by such a component of ideology as totality, the desire for mass.

Modernization processes became the basis for the creation of modern nations, and the catalyst for the rise of the national movement were the revolutionary events of the early twentieth century and the First World War. They accelerated the transformation of traditional lifestyles and, as a result, Ukrainian self-determination became a fact of history, and its independence became a concrete manifestation of the proclamation of Ukrainian statehood.

\section{CONCLUSIONS}

The study of the process of becoming a political culture, its place and role in the structure of the Ukrainian society becomes more synergistic and complex within the framework of the interaction of the humanities, which allows clarifying its influence on the assertion of identity of the Ukrainian nation more thoroughly. Drawing on the work of domestic and foreign researchers, using different scientific methods of cognition, the author tries to explore the leading tendencies of the formation of political culture in complex socio-political conditions, considering it as a process of long evolutionary character.

This process should be considered more in line with the socio-cultural development of our society. The changes of modern times were in line with modernism, which brought a new outlook and a new ideology at the heart of the idea of human ability to change the world. It is about a radical change of world outlook, creation of new paradigms of political thinking. This revolution, which continues in the current context, is closely linked to 
radical changes in all spheres of socio-cultural life. The author considers that when considering modernization processes it is necessary to understand the transition from the traditional society to the modern is always dramatic, there are different deviations from the general rules of modernization, and accordingly, there are complications. Therefore, from these positions the process of formation of political culture of the Ukrainian people is characterized against the background of significant changes in society. Systematic historical analysis shows that socio-cultural processes most adequately reflect the transitional changes characteristic of modern times, and in particular, the essence of transformations at the turn of the nineteenth and twentieth centuries.

The presence of their own cultural field, the carriers of which demonstrated the potential of integration of different styles and values, which laid the foundation for the renewal of the political mentality of Ukrainians in modern times, formed a new socio-cultural environment. This has had a significant impact on the consciousness of the social communities of all parts of Ukraine, above all on their traditional behavior and collective perceptions, i.e. key features of political culture. The processes of politicization of the Ukrainian society were unequal in the pace of development in the Russian and Austro-Hungarian empires, which demoralizingly affected the worldview and values of all groups of the population, especially the upper echelons of Ukrainian society. The growth of political consciousness and activity of the Ukrainians was hampered by elements of Russians and Russophiles, which contributed only to the defense in the regional consciousness of Russians and Poles. Cultural, social movements were not noticeable in nature until the end of the nineteenth century, which reflected on the nature of political culture.

Despite such factors and circumstances, the national idea in the early twentieth century is becoming widespread among the intelligentsia and other groups of society, and thanks to the various socio-political and cultural activities of the Ukrainians, first of all in Austria-Hungary and then on the lands controlled by the Russian Empire, they are transformed into a national community with their own political culture for the purpose of living in their own state.

- Ukraine is in a state of transition in its political history, and there is no clear picture of the current period of our past in the public consciousness. There is a difference of opinion both at the level of the collective and individual layers of consciousness of the majority of citizens of modern Ukraine. Therefore, an analysis of the essence of political culture, the peculiarities of its origins and the functioning of its various types can be productive, provided the historical approach, restoration of the completeness of historical and cultural memory of the Ukrainian people. This provides more opportunities for a comprehensive analysis of the essence of the 
political culture of Ukrainians and for understanding the dynamics of change in the role and place of Ukraine in European and world civilizations.

In today's context, the civilizational choice of Ukraine has a significant influence on the evolution of political culture, which is increasingly evolving as a synthesis of traditional domestic traits of political mentality with the adaptation of pan-European values, which opens a wider space for the formation of a modern political nation in Ukraine.

\section{SUMMARY}

The paper analyzes the process of becoming political culture of Ukrainian society in difficult conditions of influence of various external and internal factors. The author pays special attention to the consideration of scientific approaches that significantly expand the subject field of political culture functioning in the conditions of transformation of society. The problem of changes in the manifestation of political culture in different state organisms and especially the factor of preserving its identity in the absence of state support is investigated.

\section{REFERENCES}

1. Аджи М. Европа, Тюрки, Великая Степь. М.: ООО «Издательство АСТ», 2004. 473 с.

2. Андрущенко В., Губерський Л. В., Михальченко М. І. Соціальна філософія: історія, теорія, методика. К.: Генеза, 2006. 728 с.

3. Волковинський В., Іконікова I. Революційний тероризм в Російській імперії і Україна(II пол. XIX - початок XX ст.). К.: Старий світ, 2006. 416 с.

4. Грицак Я. Нариси історій України. Формування модерної української нації XIX-XX століть. К.: Генеза,1998. 360 с.

5. Губернський Л., Андрущенко В., Калакура Я., Михальченко М. Ідеологія, особистість, методолого-світоглядний аналіз. К.: Знання України, 2002. 580 с.

6. Гумилев Л. Н. Древняя Русь и Великая Степь. М.: Товарищество «Клышников - Комаров и К», 1992. 512 с.

7. Іванченко Р. П. Історія без міфів: бесіди 3 історії української державності : навч. посіб. 2-ге вид., переробл. і допов. К.: МАУП, 2006. $624 \mathrm{c}$.

8. Калакура Я., Рафальський О., Юрій М. Українська культура: цивілізаційний вимір. К.: ІПіЕНД ім. І. Ф. Кураса НАН України, 2015. $496 \mathrm{c.}$

9. Касьянов Г. В. Український націоналізм: проблема наукового переосмислення. Украӥнський історичний журнал. 1998. № 2. С. 39-54.

10. Когут 3. Російський централізм i українська автономія: Ліквідація Гетьманщини, 1760-1830. К.: Основи, 1996. 317 с. 
11. Кривицька О. Дискурс пограниччя в соціокультурних дослідженнях: теоретично-методологічні аспекти. Наукові записки: ІПЕНДім. І. Ф. Кураса НАН Украӥни. 2015. Вип. 4(78). С. 173-197.

12. Малес Л. Розуміючий потенціал соціокультурного аналізу.Якісні дослідження в соиіологічних практиках: Навч. посібник / За ред. Н. Костенко, Л. Скокової. К.: Інститут соціології НАНУ, 2009. C. 77-95.

13. Нагорна А. Історична культура: концепт, інформаційний ресурс, рефлексивний потенціал. К.: ІПіЕНД ім.І.Ф.Кураса НАН України, 2014. $382 \mathrm{c.}$

14. Проблеми теорії ментальності / Ред. М. В. Попович. К.: Наукова думка, 2006. 404 с.

15. Радзієвський В. Базові резонансні субкультури сучасної України: монографія. К.: Логос, 2014. 661 с.

16. Резник В. Теоретико-методологические семинары в Институте социологии НАН Украины. Социология: теория, методы, маркетинг. 2013. № 3. С.180-187.

17. Рюзен Й. Нові шляхи історичного осмислення. Львів: Літопис, 2010. 358 с.

18. Субтельний О. Україна: історія. К.: Либідь, 1991. 512 с.

19. Уварова Т. Постмодернізм як нова парадигма української культури. Аркадія. Культурологічний та мистеитвознавчий журнал. 2009. № 2(24). С. 12-16.

20. Фром Э. Бегство от свободы. Тайна порока. Харьков: Эдис, 1995. C. 168.

21. Шевченко Н.В. «Ягелонська спадщина» у світлі сучасних українських історичних студій. Історичний архів. Миколаїв, 2008. Т. 1. C. 29-39.

22. Шейко В. Культура України в глобально-цивілізаційному вимірі (історико-методологічні аспекти). К.: Інститут культурології НАМ України, 2011. 624 с.

23. Юрій М.Ф. Соціокультурний світ України: Моногр. 2-е вид. К.: Кондор, 2004. 736 с.

\section{Information about the author: Sushko A. I., Associate Professor,} Associate Professor at the Department of Political Theories of the National University «Odessa Law Academy» 2, Academichna str., Odesa, 65009, Ukriane 


\section{FEATURES OF ETHNO-NATIONAL POLITICS IN THE COUNTRIES OF CENTRAL AND EASTERN EUROPE}

\section{Vitman K. M.}

\section{INTRODUCTION}

The prospect of EU membership has enabled Central and Eastern European countries to become countries with a strong democratic system and a fully functioning market economy in the short term. Membership in the European community imposes certain obligations on the policy of the state, including on national minorities. It is a binding European standard to respect and safeguard their rights, including the right to use and develop their language and cultural heritage. All Member States of the European Union must abide by these standards and establish bodies that ensure the implementation of obligations to respect the rights of national minorities. The European Union is very careful about this issue, as many Member States have to deal with interethnic conflicts.

The problem of protection of the rights of national minorities has become so important since the adoption of the Council of the European Union Directive on anti-discrimination policy (2000/43 / EC «Implementation of the principle of equal treatment of persons irrespective of racial or ethnic origin»). ${ }^{1}$ By implementing this legal mechanism, all EU member states are obliged to implement an active policy that encourages the participation of national and ethnic minorities in public life, including in politics. Policies that equalize the chances of persons belonging to minorities in the labor market and in the public sphere. The requirements of the bodies of the European Union were of great importance for the EU candidate countries, since the adoption and implementation of legal and institutional mechanisms protecting the rights of minorities at national level was one of the elements of assessing a country's political readiness for membership (as part of the Copenhagen criteria).

${ }^{1}$ EU COUNCIL DIRECTIVE 2000/43 / EC, which implements the principle of equal treatment of persons, irrespective of racial or ethnic origin. URL: https://zakon.rada.gov.ua/ laws/show/994_a65. 
Although the European Union made specific demands on the candidate countries of the 2004 Pre-enlargement Coverage, among which the implementation of the European Standard on the Observance and Safeguarding of the Rights of National Minorities took the last place, each country chose its path of implementation. The models of ethno-national politics of the countries of Central and Eastern Europe have their peculiarities in view of the specifics of the historically predetermined and contemporary problems that each country faces.

The ethno-national issue for the European Union remains extremely tantalizing, in particular as regards legal redress. The researchers of these problems demonstrate two extreme points of view. ${ }^{2}$ Proponents of the former believe that it is necessary to set rigid standards set out in international instruments for the protection of minority rights and to require every country to comply with them. The main argument for this position is that the rights of national and ethnic minorities are fundamental human rights and must be protected by international standards. Another point of view is that the regulation of minority rights is an internal matter of the state in which they reside and should be governed solely by domestic, national law. The main argument in favor of this position is that the situation of minorities in different countries is different, so it is not necessary, and it is impossible to work out a single system of rules at the international level. Therefore, while international documents concerning the protection of the rights of national minorities are of a recommendatory nature, national legislation and the practice of its application are directly decisive for ethnic and national minorities. And since the countries of Central and Eastern Europe, which have joined the European Union, have confirmed their compliance with democratic requirements, unlike other post-socialist states, their legislation and the practice of its application also comply with democratic principles.

\section{Legal and social mechanisms for ensuring the rights of national minorities in Hungary}

The Republic of Hungary pursues the most liberal ethno-national policy in the region. It is one of the exemplary countries for the protection of the rights of national minorities, both at the legislative and practical levels, with the establishment of separate institutions to address the most pressing problems in this area. For Hungary and Romania, it is a Roma minority issue that is at its worst. In the countries there are separate state bodies dealing

2 Варфалви A. Осуществление прав национальных и этнических меньшинств Официальный сайт Научно-исследовательского института соииальных систем URL: littp://niiss.ru/mag13_natrights.shtml 
with the protection of the rights of the exclusively Roma minority. In Romania, this is the National Office for Roma. This issue will be addressed in Hungary in the context of the study of legal and institutional mechanisms for ensuring the rights of minorities, including the Roma.

Researchers say Hungary's most liberal minority policy is linked to the large number of Hungarians living outside their homeland in neighboring countries. By granting the greatest rights to national minorities, Hungary expects to obtain the same benefits for the Hungarian minority in Romania, Slovakia, Serbia and Ukraine.

Hungary's liberal ethno-national policy, focused on EU standards, has been implemented since 1990. In the Hungarian Constitution, Article 68 sets out the status of national minorities. National minorities are members of the government, they are a state-forming factor. The Republic of Hungary protects national and ethnic minorities. It provides them with collective participation in public life, the preservation and development of culture, use, teaching, the right to use names in their native language. ${ }^{3}$ Hungary's fundamental law guarantees the right of national and ethnic minorities to create self-governing bodies - both local and national, and provides for the adoption of laws to ensure representation of national and ethnic minorities living in the territory of Hungary.

The relevant bill was drafted with the active participation of minorities and passed in 1993 under the name Law on the Rights of National and Ethnic Minorities ${ }^{4}$. This law and the Constitution empower national and ethnic minorities, and their number - 13 - is defined by law, with the right to form their own self-government bodies at their places of residence. The essence of this right lies in the fact that the minority of the masses have the right to create in their settlement and at the state level their self-government, which is designed to solve the issue of preserving the cultural and linguistic identity of this minority. A municipal government can declare itself a minority government if more than 50 percent of its elected members are of a particular national or ethnic minority. This is possible provided that in a particular settlement or district of Budapest a national or ethnic minority constitutes a majority of the population, a majority of minority representatives are elected in accordance with the local authority. In practice, it turns out that in this locality a minority self-government body carries out

3 Конституция Венгрии (Венгерской Республики) // Конституции государств Европы.- М.:НОРМА, 2001. 356 с.

4 Act LXXVII of 1993 on the Rights of National and Ethnic Minorities. URL: https://www.minelres.lv/ NationalLegislation/Hungary/Hungary_Minorities_English.htm 
administrative management. That is, the minority gains some territorial autonomy.

If more than 30 percent of representatives of a certain minority are elected to a local government body, they can indirectly create a minority self-government body consisting of at least three persons.

The legislation provides for the right of national minorities to establish self-government bodies at the national level as well. In addition to agreeing on issues related to cultural autonomy, the tasks of these bodies include expressing the position of this minority on all issues of urgency to it, as well as ensuring the proper protection of the interests and rights of the minority or its representatives at the Hungarian level.

The system of establishing local self-government bodies was first tested after the 1994 Law on the Rights of National and Ethnic Minorities in the municipal elections in 1994. Not all minorities have shown a desire to create local governments. The Roma were the most active, and the Ukrainians became the only one of the 13 minorities who did not want to have their own self-government. However, Ukrainians do not belong to the largest national minority in Hungary. The ethnic composition of this multi-ethnic 10million country is dominated by the titular ethnic group, the Hungarians make up 89.9 percent of the population. The largest minorities are: Roma 4 percent, Germans -2.6 , Serbs -2 percent, the rest - Slovaks, Romanians, Croats and others - do not exceed one percent. ${ }^{5}$

In general, all legislative acts, targeted programs in Hungary are aimed at the widest possible protection of the rights of national minorities in accordance with European norms and standards. The main focus in ethnonational politics is on maximizing the involvement of ethnic and national minorities in government. This is done through close co-operation of minorities with public authorities through the interaction of minority selfgovernment bodies or through the inclusion of these bodies in the public authority system.

The Hungarian Constitution and the Law on the Rights of National and Ethnic Minorities establish the concept of positive discrimination. Accordingly, national and ethnic minorities have the right not only at the level of the titular ethnic group of opportunity, but also to additional mechanisms for their implementation, which are provided to them by the government through appropriate government programs and legal mechanisms. Positive discrimination sometimes transfers into discrimination

5 Вітман К.М. Етнонаціональна політика постсоціалістичних країн: моделі, особливості, проблеми:монографія. К.: Лотос, 2007. С.68. 
against the titular ethnic group, so protected are the rights of minorities in democratic countries.

Self-government bodies are a unique solution to an ethnic issue. Hungarian law empowers ethnic and national minorities with effective and powerful mechanisms to resolve their own problems and ensure their interests. As a result, granting minorities the right to formulate public policies at local and national levels in this way can be taken only after their agreement or consultation with minority bodies. For example, a local authority of a settlement requires the consent of a minority self-government body, even to appoint a school principal, if it concerns the teaching of a national or ethnic minority. No decision can be taken without proper consent.

Mandatory consultations are held with national self-government bodies in the preparation of bills related to the conservation and development of the historical heritage of minorities and the definition of educational programs for them. National minority bodies at the national level have the right to make suggestions or recommendations when discussing a government report on the situation of minorities in Hungary. Local governments also have the right to make inquiries with any government body about minority issues.

Thus, a powerful legislative mechanism to involve national minorities in the political process of the state was created at the local and national levels in Hungary.

In addition to legal mechanisms that allow minorities to form effective bodies for the protection of their rights and interests, Hungary has created effective institutional mechanisms within the system of public authorities designed to ensure the proper development of all national and ethnic minorities in the country. The first is the Ombudsman for National and Ethnic Minorities. Establishment of an institution of a special parliamentary ombudsman - the Ombudsman for National and Ethnic Minorities is provided for in Article 32 / in the Constitution, which also defines the main function of the Ombudsman for Minorities - to investigate or commission an investigation into known violations of the rights of national and ethnic minorities and to act on behalf of others measures to remedy these violations. The Ombudsman is thus responsible for investigating any abuse and violation of the rights of national minorities. The Law on Parliamentary Guarantees of Citizens' Rights regulates in more detail the functions and powers of the Ombudsman for the Rights of National and Ethnic Minorities.

The Ombudsman's nomination is coordinated by the President with the national minority self-government bodies at the national level, in the absence of such bodies, with a registered body representing the interests of a particular national or ethnic minority. The proposed nomination is approved by Parliament by two thirds of the votes. 
The second institute is the Office for National and Ethnic Minorities. It was created by the Hungarian government back in 1990 to coordinate governmental tasks and programs for the development of national and ethnic minorities living in the country. The Office for National and Ethnic Minorities is subordinate to the Ministry of Justice, which, among others, performs the functions of legal control over the regulation and legislation of national minorities. Although the operation of the Office is supervised by the Minister of Justice, the Office for National and Ethnic Minorities is an independent governmental organization with national jurisdiction. It is headed by its Director, who is appointed and dismissed by the Prime Minister upon the submission of the Minister of Justice.

The Office for National and Ethnic Minorities liaises with the Minority Ombudsman and cooperates with national minority self-government bodies and other minority interest organizations in Hungary. The Minority Office directly maintains close contact with all national and ethnic minorities residing in Hungary and has the following departments: the Roma Department; German minority Department; the Romanian Minority Department; Department for Croatian and Slovenian Minorities; Department for Bulgarian, Greek, Armenian and Serbian Minorities; Department for Polish, Russian, Slovak and Ukrainian minorities; Department for Legal Affairs and Local Authorities; Department of International Relations; Minority Research, Information, Documentation and Analysis Department; Financial Department.

According to the Law on the Rights of National and Ethnic Minorities, the government must submit to Parliament twice a year a comprehensive report on the current status of minorities in Hungary. The Office for National and Ethnic Minorities prepares this report and is responsible for it.

Director of the Office of Minorities assumes the duties of chairman of the Board of Trustees of the Public Foundation for Minorities - another institute established to implement programs that ensure the preservation of national and ethnic identity of minorities, the development of their cultures and the protection of interests. Its operation is provided for by Article 55 of the Law on the Rights of National and Ethnic Minorities, according to which the Public Fund is established by the Government with its headquarters in Budapest. This fund provides the bulk of the financial resources for cultural events, programs, bookkeeping support and national minority periodicals.

In particular, the Roma Community Fund operates as the most numerous and problematic minority in Hungary. It supports the development of small businesses, employment programs and Roma health care. The Hungarian Budget Law provides for the annual allocation of funds to the Public Minority Fund and the Public Roma Fund. The trustee boards of these funds are responsible for determining the mechanism of use of these funds. 
The main decision-making body of the Public Foundation for Minorities is its Board of Trustees, which includes:

- one representative from each national minority self-government body elected at a general meeting, and in the absence of a national body, a representative elected by minority organizations;

- one representative from each party represented in parliament;

- one representative from the Ministry of the Interior, the Ministry of Foreign Affairs, the Ministry of Cultural Heritage, the Coordination Council for Children and Youth and the President of the Hungarian Academy of Sciences.

This is not limited to the institutional body of authorities whose task is to exercise the rights of Hungarian national and ethnic minorities. In 1995, the government created an inter-ministerial committee, comprising representatives of all ministries and bodies responsible for ethnic politics. The Committee's mandate included drafting bills, action plans, monitoring program implementation and coordinating minority policy.

Thus, in Hungary, there is more than one ministry dealing with issues of national and ethnic minorities at the national level. Minority issues also lie within the functional responsibilities of the Department of Public Education and Minority Relations in the Ministry of Education, the Department of National and Ethnic Minorities in the Ministry of Cultural Heritage, the Department of Labor Market Programs and the Department of Social Welfare in the Ministry of Social Policy and Affairs. That is, in any area of government, minorities are given particular attention. The Office of the Prime Minister has a Public Relations Division responsible for engaging with civil society organizations, including establishing and maintaining contacts with non-governmental minority organizations. Thus, the entire state apparatus of Hungary is in one way or another imbued with the function of protecting the rights of national and ethnic minorities.

In addition to legal and institutional protection, effective social mechanisms are in place in Hungary to enable national and ethnic minorities to exercise fully their right to their national or ethnic identity. These mechanisms create a favorable social atmosphere in which members of national minorities can freely declare, defend and develop their national or ethnic identity.

In Hungary, one cannot freely express a negative opinion about a particular minority. There are legal restrictions governing minority opinion. State-owned media should also provide time and space for coverage of minority issues. The Law on Radio and Television provides for the legal responsibility of the state media for providing continuous information on the lives of national and ethnic minorities. The Ombudsman's reports on national and ethnic minorities on the basis of requests, complaints, as well as 
the Government's biennial report on the status of respect for national and ethnic minorities, prepared by the Office for National and Ethnic Minorities, are not only the outcome of the work of state bodies in the field of security minority rights, but also the starting point for new programs, activities, and more.

Minority Day in Hungary is a social mechanism. The Hungarian government declared December 18, the day the General Assembly adopted the OOP Declaration on Human Rights, National, Ethnic, and Religious Minorities in 1995 - Minority Day, to draw public attention to ethnic issues and to support and develop the most favorable social climate for development minorities. Minority Prize is awarded by the Prime Minister of Hungary during the celebration. It is received annually by foreigners or Hungarians, organizations, self-governing bodies of minorities who demonstrate outstanding achievements in the public sphere, education, culture, religion, science, media, business, and minority interests.

\section{Romania: problems of interethnic interaction}

Despite the territorial neighborhood, the situation of minorities in Romania and Hungary is fundamentally different. Throughout history, Romania has had to deal with many complex issues in the area of interethnic relations. After the First World War and in the interwar period, ethnic tensions increased in the country. As a result of the war, accession and annexation, the territory and population of Romania has doubled. In addition, ethnic composition has changed significantly: the number of national minorities was more than a quarter of the population.

Without a brief excursion into the history of interethnic relations in Romania in the twentieth century, it is impossible to understand the contemporary problems of an interethnic nature. The constitution of 1923 resolved the problem of interethnic relations on the principle of equal rights, civil and political freedoms to all minorities of Romania. Immediately after the liberation of Romania, a new legal document regulating the status of national minorities - the Decree Law on the Status of National Minorities appears. After the Second World War, the Hungarians remained the largest minority, increasing to 10 percent due to Romania's accession to Northern Transylvania. The decree-law proclaimed the equality of all citizens before the law, granting them the same civil, political and legal rights regardless of race, nationality, language and religion (Articles 1,4). A separate section enshrined the right to use one's own language, that is, the language of the national minority, in all administrative and judicial bodies in areas where national minorities made up at least 30 percent of the population. Legislative acts which were adopted after August 23, 1944 were translated into national languages. National minorities were guaranteed the right to receive 
education in their mother tongue at all levels of the education system, including higher education. Judicial and administrative officials in areas where minorities made up at least 30 percent of the population «were obliged to speak the languages of their respective nationalities» (Art. 12). ${ }^{6}$

The next constitution established a new administrative-territorial division, which was developed taking into account the national peculiarities of the regions and envisaged the creation of a separate Hungarian Autonomous Region with extremely wide internal powers. The Hungarian Autonomous Region was created to use the Transylvanian problem to maintain the required Hungarian-Romanian balance in the region.

The Transylvanian problem is that this historic territory with a mixed Hungarian and Romanian population, which is now almost a quarter of Romania's territory, has repeatedly moved from Hungary to Romania, and vice versa. Mutual claims have not disappeared as Romania has gradually begun to revise its policy towards the Hungarian minority. Following the withdrawal of Soviet troops in 1958, the rights of the Hungarian Autonomous Region were restricted, and higher education opportunities reduced in Hungarian (Hungarian University of Cluj was merged with Romanian). Trends in moving away from democratic principles of resolving the national issue are being traced. For example, in the postwar years, against the background of giving preferences to the Hungarian national minority, another minority, the second largest in the country, remained discriminated against. It's the Germans. The German minority was directly responsible for co-operation with Nazi Germany. Most Romanian Germans were subject to unjustified restrictions on civil rights and freedoms, confiscation of property, expropriation of land ownership and real estate.

Subsequently, national communism Ceausescu led to the assimilation of national minorities. As early as the 1960's and 1970's, the term «national minorities» was replaced by «cohabiting nationalities». The assimilation course was based on the concept of a «single Romanian nation». These and other social experiments culminated in the revolution of 1989, which gave rise to many expeditions in the environment of national minorities, but did not satisfy all. The national composition of Romania has not changed much since then. The titular ethnic group is about 89.5 percent of the population; the largest minority are Hungarians - 7.1 percent; the second largest Gypsies, 1, 8 percent; the third - the Germans, 0, 5 percent; other minorities (Ukrainians, Russians, Turks, Crimean Tatars, Serbs and Slovaks) make up

\footnotetext{
${ }^{6}$ Декрет-закон о статусе национальных меншинств // Конституция и основные законодательные акты Румынской Народной Республики М. Изд-во иностранной литературы, 1950. С. 109-114.
} 
0.8 percent of the population. ${ }^{7}$ The main legal instrument for the protection of the rights of national minorities remains the Basic Law. The Constitution of Romania of 1991 guarantees to persons belonging to national minorities the right to preserve, develop and display their ethnic, linguistic, cultural and religious identity (Article 6, Paragraph 1). At the same time, the protection measures applied by the state to preserve, develop and manifest the identity of persons belonging to national minorities must comply with the principles of equality and non-discrimination against other Romanian citizens (Article 6, paragraph 2). With this provision, the constitution seeks to prevent the positive discrimination that Romania has had in its history.

The political rights of minorities, including the right to have representation in the legislature, should be mentioned separately. Representatives of national minorities are elected both to the lower house the Chamber of Deputies and to the Senate. If the national minority did not secure the passage of their representative to parliament, the Constitution provides it the right of representation by a separate provision ${ }^{8}$. Para. 2 of Article 59 establishes that organizations of citizens belonging to national minorities who do not vote in the elections for a sufficient number of votes for representation in the parliament are entitled to one deputy seat each, subject to the conditions established by the election law.

The Romanian Constitution also regulates minority language rights. Despite the fact that the Romanian language is called native for 89.5 percent of the population and Art. 13 of the Constitution proclaimed that «Romanian is the official language in Romania», it guarantees the right of persons belonging to national minorities to study their mother tongue and receive education in their mother tongue (Para. 3 of Article 32).

However, in the 1990s, the situation for Romanian national minorities was far from democratic, despite the fact that according to the Romanian Constitution, in international instruments for the protection of national minorities ratified by Romania, priority was given to those that provide not only the rights of national minorities but also state relations in preserving their identity, creating favorable conditions for the development of culture, language and religion, taking into account the interests of national minorities by the state in domestic and foreign policy. Romania was in no hurry to fulfill these responsibilities. Even now, according to an analysis of the legislation by the Center for Human Rights and the Association for Human

${ }^{7}$ Вітман К.М. Культурна автономія як потенційний механізм забезпечення прав національних меншин Румунії // Актуальні проблеми політики. Збірник наукових праць / Голов. Ред. С.В. Ківалов; відп. за вип. Л.І.Кормич. - Одеса:ПП «Фенікс», 2007. Вип. 30. C. 399.

${ }^{8}$ Конституція Румунії. URL: // http://www.ilpp.ru/8508757867 
Rights Protection in Romania, national legislation does not fully meet the democratic requirements of securing minority rights. Meetings of local authorities, even in regions where national minorities make up a large proportion of the population, are held in an official language. Representatives of national minorities may file complaints, applications to local governments in their native language, but with translation into Romanian, which is required along with the application.

The situation of national minorities in the political sphere was not the best, despite the guarantees given to them by the Constitution. In Romania, all minority organizations have the status of parties. Other Romanian parties do not like this very much. They are still unanimous in the fact that there are too many national minorities in Romania and they either need to be reduced or their rights restricted. In particular, some political forces have sought to pass through the legislature a law that impeded the passage of national minorities to parliament. Even in local elections, it is difficult for national minority organizations and parties to compete with other Romanian political forces.

In elections to local authorities in 1992, 1994, when there was no electoral threshold (the number of votes required to obtain one mandate was required), 10 minorities won deputies in local councils. Hungarians - in all counties of Transylvania, Banat and Krishna ${ }^{9}$. The Germans - in the three counties of Banat and in Sibiu. Even Roma, known for their political inactivity, even though they make up 5 per cent of the country's population, have gone to local authorities. Three Roma parties received mandates. In addition to the aforementioned minorities, Russians, Ukrainians, Slovaks, Poles, Greeks, Serbs, Turks and Tatars also sat in the seats. But in 2000, a 3 percent barrier was introduced in local elections, up to 5 percent in 2004. This substantially restricted the activity of national minorities in local government elections.

Such measures are contrary to the declared principles of the protection of national minorities, especially for a Member State of the European Union. For all national minorities, except Hungarian and German, such a barrier is insurmountable. To tell the true, other political problems were solved in this way, but doing so at the expense of the rights of national minorities is unacceptable in a democratic state. Raising the barrier, the legislator sought to stabilize Romania's rather entropy, chaotic political system.

A serious restriction on the rights of national minorities in Romania was the adoption of the Education Act of 1995, which restricted the possibility of representatives of national minorities to receive education in their mother

9 Sandru V. Aspects of Romanian Experience in Building Democratic Inter-Ethnic Relationships. Romanian Journal of International Affairs. 1996. Vol. 2. P. 219. 
tongue far more than previous education laws. It enforced the norms that aroused national minorities. Entrance and graduation exams in the mother tongue can only be taken in schools or high schools where teaching is done in the minority language or there are departments in higher education. However, the limited number of such institutions at the lyceums, high schools, and even more so in higher education institutions, forced parents to send their children to Romanian-language schools. University education in the mother tongue of national minorities was provided for only two specializations - pedagogy and culture. A whole barrage of protests prompted a textbook and the title of the course - «Romanian History» instead of «Romanian History», which minimized the study of the contribution to Romanian national minority history. In addition, the provisions of the Act excluded the possibility of returning nationally owned private and denominational schools of nationality in 1948. While national minorities have criticized this law on education, nationalist Romanian circles have called it too liberal. The National Unity Party saw in the Law the danger of a privileged position of national minorities and discrimination against the Romanian language. An open letter from the party to the President of Romania stressed that the adoption of the law would lead to segregation of education through the organization of ethnic-based schools, the dismissal of Romanian teachers and the exclusion of Romanian students from mixed schools, and would continue the process of «madiranization of Romanian in the districts» ${ }^{10}$. But the law was passed despite the discontent of both parties. The European Parliament immediately responded to this by a resolution condemning Romania for passing a law that violates the rights of national minorities. Protest rallies of national minorities took place in the country.

Due to the lack of consensus on ethnic politics in Romania in the 1990s, the law on national minorities was not passed and the need for it was over. Several draft laws were actively discussed. The main drawback of the draft law from national minorities, which relied on international experience, was the recognition that the rights of national minorities were considered in it as a component of human rights and accordingly provided for the right to internal self-determination, personal, local and territorial autonomy. In addition, this draft, which provided for the right of national minorities to autonomy, was put forward by the Romanian Democratic Union of Hungarians. And since the time of Ceausescu, the concept of internal selfdetermination and territorial autonomy has been regarded as a direct threat to maintaining the unity of the Romanian state. As the draft law was crushed by

10 Кравченко Т. Проблема прав национальных меньшинств в Румынии (вторая половина 40-х - 90-е годы). URL: http://liber.rsuh.ru/Conf/FreedomlI/kravchenko.htrn 
criticism, Romania's Democratic Union of Hungarians abandoned territorial autonomy, leaving only cultural. However, no compromise has been reached.

Even the slightest hint of the issue of autonomy in Romania is seen as an assignment to Hungarian separatism. And it is not grounded, as Hungary supports these trends in Romania. A conference on Hungarian diaspora issues took place in Budapest in 1995, during which the principle of combating the autonomy of the Hungarians in Romania was publicly announced. In 1996, a corresponding Declaration was adopted stating that the Hungarian Republic was «responsible, as stated in the Constitution, for Hungarian communities abroad». Hungary's activity in Romania was seen as an attempt to interfere in the country's internal affairs and threaten the integrity of its territory. Thereafter, a co-operation and support agreement was signed between Romania and Hungary to join the European Union, based on the rejection of territorial claims, which Romania sought.

However, this treaty did not change Romania's conceptually different approach to ethno-national policy. The state component in it continues to dominate. Romania's ethno-national policy envisages the integration of national minorities into the Romanian community while preserving their national and cultural identity, but which is particularly emphasized in the light of the fundamental rights of the state of which they are nationals.

This approach is not endorsed by a united Europe. Therefore, the scientific and political circles of Romania are returning to the idea of cultural autonomy every time. After all, cultural autonomy in no way threatens the territorial integrity of the country, as it is granted to representatives of the minority and not to the territorial community. Cultural and territorial autonomy are radically different. Cultural autonomy implies that all citizens - both the titular ethnic group and the minorities - are interested in increasing the welfare and development of the state in which they live. As noted by leading Baltic German interwar period theorist Paul Schillman, «Minority policies must work for the state in which they reside; any other approach to politics is detrimental». Therefore, it is only possible to allow a national minority to carry out their cultural life autonomously when it demonstrates complete loyalty to the country of residence ${ }^{11}$.

From this it follows that the mechanism of recognition in the form of cultural autonomy does not at all mean the automatic creation of a «state in a state» (which equates a national minority to a state), something that Romanians fear when discussing the issue of granting cultural autonomy to the Hungarians. On the contrary, the theory of cultural autonomy

${ }^{11}$ The Cultural Autonomy of Etnic Minorities in Estonia . URL: http://www.linst.ee/faetshects_uus_knjii/thc_cultural_autonomy_of_etnie_minorities_in_esto 
presupposes the existence of a state as a civic community and a territory populated equally by a minority and a majority. In other words, cultural autonomy creates a common territorial space. The law on cultural autonomy applies only to citizens and only citizens are entitled to form it.

National minorities in Romania enjoy universal rights as citizens of the state and additional specific rights that ensure the development of their ethnic identity as a minority. However, the prerogative of securing these rights is reserved only to the State of residence, provided that other States do not interfere. In Romania, however, special emphasis is placed on the fact that in international instruments regulating the rights of national minorities, their responsibilities as citizens of the state in which they reside are not sufficiently reflected, and therefore, the rights of national minority representatives are not protected, the case of the Romanian nation living in compact settlements of national minorities. In Romania, the issue of developing a mechanism for accountability of states for rhetoric and actions against their minorities and the titular ethnic group is rather rigid ${ }^{12}$.

\section{CONCLUSIONS}

Thus, the Republic of Hungary has created one of the best post-socialist countries in the region to secure rights, interests and create favorable conditions for the development of identity, culture, language of all national and ethnic minorities living in its territory. This system contains powerful legal mechanisms for the protection of minorities by involving them in the government system on a voluntary basis in the form of forming local selfgovernment bodies of minorities. Hungary's effective legislation has made it possible to build a state apparatus in such a way that, at all levels, it participates in the internal policies of national and ethnic minorities, their representatives or bodies representing their interests. No decision, even indirectly concerning a minority, can be made without its consent, even initiated without consultation with a minority. To this end, a considerable number of institutional mechanisms are functioning directly within the system of public authorities, such as the Ombudsman of Minorities. The parallelism and complementarity of legal, institutional and social mechanisms for the protection of minorities creates an interpenetrating network of opportunities and ways of securing and realizing rights and interests by Hungary's national and ethnic minorities.

Thus, securing the rights of national minorities in Romania is not yet recognized as a public value, a priority for Romania as a multi-ethnic, multicultural state, and they are still considered a threat to national

12 Сака В. Национально - возрожденческие отношения как фактор транзита к демократии (Молдова, Румыния, Украина). URL:http://www.e-journal.ru/bzarub-st3-17.html 
sovereignty. But a democratically resolved national issue can lead, even in the opinion of some Romanian scholars, to separatist tendencies and interethnic conflicts. Considering at least that the most problematic minority - the Hungarians - are able to support these trends from their ethnic homeland. Moreover, Hungary is considered to be a model country among the countries of Central and Eastern Europe in terms of protection of the rights of national minorities. Therefore, even in view of her image, she cannot leave the Romanian Hungarians for granted.

In view of all the above issues, Romania has become one of the most problematic candidates for EU membership because of the poor state of protection of national minority rights. And, as you know, the problem of exercising their rights is one of the most delicate, difficult to solve, especially in a transitional period in Romania. On the one hand, the state is trying to demonstrate Romania's movement at all levels to meet EU standards in this field, and on the other, the position of national minorities remains unsatisfactory due to internal resistance in the Romanian society itself and lack of consensus on this issue.

\section{SUMMARY}

The features of ethno-national politics in the countries of Central and Eastern Europe are studied, in particular the legal and social mechanisms in Hungary and the problems of interethnic interaction in Romania. The peculiarities of the implementation of ethno-national politics, determined by the priorities and rates of social transformation in these countries, are determined. The political and legal bases for the protection of the rights of national and ethnic minorities are analyzed.

\section{REFERENCES}

1. Act LXXVII of 1993 on the Rights of National and Ethnic Minorities. URL: https://www.minelres.lv/ NationalLegislation/Hungary/Hungary_ Minorities_English.htm

2. EU COUNCIL DIRECTIVE 2000/43 / EC, which implements the principle of equal treatment of persons, irrespective of racial or ethnic origin. URL: https://zakon.rada.gov.ua/ laws/show/994_a65

1. Sandru V. Aspects of Romanian Experience in Building Democratic Inter-Ethnic Relationships. Romanian Journal of International Affairs. 1996. Vol. 2. - P. 219.

2. The Cultural Autonomy of Etnic Minorities in Estonia URL: http://www.linst.ee/faetshects_uus_knjii/thc_cultural_autonomy_of_etnie_minorities_in_esto

3. Варфалви А. Осуществление прав национальных и этнических меньшинств. Официальный сайт Научно-исследовательского 
института социальных систем URL: http://niiss.ru/ mag13_natrights.shtml

4. Вітман К.M. Етнонаціональна політика постсоціалістичних країн: моделі, особливості, проблеми. - К.: Логос, 2007. - 336 с.

5. Вітман К.М. Культурна автономія як потенційний механізм забезпечення прав національних меншин Румунії // Актуальні проблеми політики. Збірник наукових працьь. 2007. Вип. 30. С. 394-402.

6. Декрет-закон о статусе национальных меншинств // Конституция и основные законодательные акты Румынской Народной Республики / ред., авт. предисл. С. Н. Соловьев. М. : Издательство иностранной литературы, 1950. 240 с.

7. Конституция Венгрии (Венгерской Республики) // Конституции государств Европы.- М.:НОРМА,2001. - 356 с.

8. Конституція Румунії URL: http://www.ilpp.ru/8508757867

9. Кравченко Т. Проблема прав национальных меньшинств в Румынии (вторая половина 40-х - 90 -е годы) URL:http://liber.rsuh.ru/Conf/FreedomlI/kravchenko.htrn

10. Сака В. Национально - возрожденческие отношения как фактор транзита к демократии (Молдова, Румыния, Украина) URL: http://www.e-journal.ru/bzarub-st3-17.html

11. Чепулкаускайте Е. Венгрия: система образования: политическая обстановка и историческая справка URL: http://www.sociumas.1t/Rus/Nr3/mazumos.asp

\section{Information about the author:} Vitman K. M., Doctor of Political Sciences, Professor, Professor at the Department of Political Theories of the National University «Odessa Law Academy» 2, Academichna str., Odesa, 65009, Ukraine 
DOI https://doi.org/10.36059/978-966-397-158-2/225-242

\section{SYMBOLIC ATTRIBUTION OF STATE SOVEREIGNTY AS A FACTOR OF POLITICAL TRANSIT: THE POST-SOVIET EXPERIENCE}

\section{Mamontova E. V.}

\section{INTRODUCTION}

In the context of the generally accepted understanding of political transit as a state of change in the characteristics of the political system in the transition from one political regime to another, the vector of democratic transit is defined by the coordinates «authoritarianism - democracy». However, as practice shows, democracy is not a necessary result of this process. Among the reasons for this situation are almost all the basic theoretical models of the transition of the state from authoritarian to democratic political regime (structural (G. Almond, S. Verba, R. Dahl, R. Inglihart, D. Rastow, R. Rose), procedural (G.O'Donnel, F. Schmitter, H. Linz, A. Stepan), integrative (J. Mahoney, R. Snyder), synthetic (S. Larsen, A. Melville), called slowing down of the transition in the phase of consolidation of democratic values at the level of the cultural code. In order for democratic development to become irreversible, not only political decision-making, awareness and perception of democratic rules and procedures, the establishment of democratic institutions, but also the consolidation of democratic values, are needed (D. Rastow, A. Przeworski, G. O'Donnell, F. Schmitter, etc.). The latter is influenced by national and cultural-value factors, among which symbolism occupies an important place.

History has repeatedly proved that systemic transformations always affect the symbolic sphere of society. Typically, the first indicator of these transformations is state symbolism, which, by fixing changes in the nationalstate symbolic space, consolidates state sovereignty. That is why one of the first steps to follow the act of declaration of independence is to recreate it in new symbols - attributes of state sovereignty. This provision also demonstrates the state-building experience of post-Soviet countries.

In this connection, it should be noted that as a backbone historical process of becoming a political organization of society, state formation is a multifaceted phenomenon of ontological order that covers all spheres of social life. Hence, the implementation of a state-building project requires the 
involvement of all possible resources, including non-institutional nature. Among the resources of the latter category, one of the most powerful is the symbolic resource, which we propose to define as a multifaceted tool, based on symbolic complexes formed according to their structural and functional load, which they carry in the process of state self-determination in the symbolic space of politics.

Historians are well aware that in the struggle for independence, symbols always play a huge role in proclaiming sovereignty as statehood. Under the state symbol, we suggest to understand a special, historically formed, distinctive sign of a state, which is embodied in its sovereignty and carries an ideological burden, established by the constitution or a separate law. It should be noted that each of the symbols of state sovereignty - the flag, the emblem, the motto and the anthem - fulfill their special mission, and together they create a coherent semantic text interwoven with the discourse of politics.

So, the flag is historically the first state symbol and, thanks to the totemic nature and abstract nature of semantics, acts as the nucleus of the civic symbolosphere and is the constituent structure of the state symbolic space. The peculiarities of the emblem as a state symbol are conditioned by the fact that it is a sign of institutional attribution. Hence the emblem is, above all, a symbol of official power in the country. The state motto, which became part of state symbols as a result of the transformation of dynastic coats of arms into state (imperial), articulates the mission of the state and its goals in a concise form. The State Anthem, in turn, contains a message in an external communicative environment that contains an annotated text about the worldview universals of the nation.

Review of state symbols in the context of their ontological status, historical origin and semantic load, indicates that as the most specified ideological manifesto of universal principles of national and statesman's outlook, the anthem complements the metaphorical and interpretative nature of the abstract flag and emblem symbols and together, which acquires systematic properties. This symbolic complex of attribution (hereinafter SCA), being a symbolic formation, is transformed with changes of spiritual priorities, values of society and reflects systemic transformations in its political sphere.

All this was fully evidenced by the history of independence of the postSoviet countries.

Let's try to explore the main stages of the formation of symbolic sovereignty in young countries that emerged in the former USSR, and to identify and correlate the political and sociocultural determinants of social 
development on the basis of identifying and comparing their characteristic features. The solution to this problem will enable us to achieve the goal of our research, namely to reveal the peculiarities of the symbolic attribution of state sovereignty as a factor of political transit and to evaluate its statebuilding potential.

\section{Symbolic representation of democratic transit: from transitional societies to consolidated democracy (for example, the Baltic countries, the Caucasus and the Caucasus, Moldova)}

The first acts that gained symbolic meaning on the difficult path of free political self-determination of the new countries and its constitutional consolidation were the Declarations of Sovereignty and Independence brief, meaningful documents that outlined the basic principles that characterized their independence and sovereignty and, at the same time, symbolized peoples' desire to enter the circle of democratic countries of the world. The further trajectory of the state-making process was determined, in our opinion, by such significant events in its development as the change of the official name of the country, the acquisition of new symbols of state sovereignty, the adoption of the Constitution.

At the forefront of these changes were the Baltic countries, which were the first among the Soviet republics to abandon communist symbolism.

Leading among them was Lithuania, which was able not only to restore and legalize historical symbolism, but also to consolidate it in the legal field of the USSR, giving it state status. On November 18, 1988, the Supreme Soviet of the Lithuanian SSR adopted a law "On Amendments to Articles 168 and 169 of the Constitution of the Lithuanian SSR», according to which the State Flag of the republic was proclaimed «a State Flag consisting of three equal horizontal stripes: upper - yellow, medium - green, middle - green, lower - red» ${ }^{1}$. A new norm for the size of the State Flag was also symbolic. The Soviet flag etiquette in force at the time suggested that while the flags of the USSR and the republics were being used at the same time, the latter could not be larger than the Union flag (it had a 1:2 ratio). However, it was expected that the newly proclaimed republican flag would become an equal State Flag.

Article 169 of the Constitution of the Lithuanian SSR approved the «National song» of V. Kudirka as the State Anthem. On March 11, 1990, on the day of the proclamation of the Act on the Restoration of Lithuanian Independence, the Parliament of the Republic adopted a law «On State

${ }^{1}$ Про изменение статей 168 та 169 Конституции Литовськой ССР: Закон Литовской РСР от 18.11.1988 г. Советская Литва. 1990. 19 ноября. 
Name and Coat of Arms», which approved the new name of the country and approved as the official State Emblem of the Republic of Lithuania an image of Vitis - a rider in the armor, considered a heraldic sign of the Lithuanian territories. However, the reference images of the coat of arms and its description were later adopted by a separate law «On the State Emblem of Lithuania» of April 10, 1990. The systematic transformations were evidenced by the re-approval of the national tricolor by the Law «On the State Flag of Lithuania», adopted by the Verkhovna Rada on June 26, 1991.

In a similar scenario, there were changes in the attribute complex of Estonia. In general, the model of the acquisition of symbolic sovereignty of the republic was defined by the coordinates: «from the legislative consolidation of national symbols to the legalization of symbols of the statehood of the pre-Soviet period» and continued from the fall of 1988, when the Decree of the Presidium of the Supreme Soviet of the Estonian SSR of October 20, 1988 «On Approval of the Regulation on the Procedure for the Use of the National Symbols of Estonia» the national blue-blackwhite flag was renewed and national cornflower and swallow were designated by the end of 1990).

A few years later Lithuania and Estonia decided to attribute symbolically their independence to Latvia. On February 15, 1990 the Laws «On Amendments to the Constitution of the Latvian SSR», «On the State Emblem», «On the State Flag» and «On the State Anthem» returned the status of state one to pre-war symbols of the country. The State Flag again became a carmine-red cloth with a longitudinal white stripe in the middle.

With the introduction of the presidency institute in the state, which was renewed in the summer of 1993 with the Constitution of 1922, the use of the pre-war presidential flag (standard) was restored.).

Thus, the formation of the symbolic complex of attribution of the Baltic countries was based on the return and legalization of the heraldic system of the pre-Soviet interwar period with a final and unanimous rejection of communist symbolism and can be regarded as a progressive process, organically woven into transformational changes of a systemic nature. And today, relying on the ideology of the Soviet occupation, the Baltic countries often use symbolism to solve all kinds of domestic and foreign policy problems. Where the language of diplomacy does not work, the techniques of «symbolic wars» that we have repeatedly witnessed in recent years have been effectively used.

Thus, as the experience of the symbolic self-determination of the state sovereignty of the Baltic countries testifies, the dramaturgy of the formation of the symbolic complex of attribution is clearly linked to the political and sociocultural determinants of social development. Thus, in the countries of the region where democratic political regimes were formed today, in the process of independence, a radical reformation of the symbolic space took 
place on the basis of the return to the historical symbols of the statehood of the pre-Soviet model. Given that this process took place in a situation of absolute civic support, it can be argued that in societies dominated by (or gravitating to) the democratic system of values in the processes of statebuilding, national symbolism becomes the subject of the political process. Performing the traditional political symbolism functions of mobilization and integration, national symbolism becomes a real catalyst for political transformations.

The process of symbolic attribution of the state independence of the Soviet republics of the Caucasus and the Transcaucasia was somewhat similar. However, unlike the Baltic countries, whose symbolic selfdetermination was the unconditional and complete resuscitation of the symbolism of the pre-Soviet period, the specificity of the political history of the Caucasian territories, which resulted in the absence of a systematic heraldic tradition among the peoples of the region, determined the independence of the governed people and their independence to the arsenal of national historical symbolism.

Thus, the symbolic self-expression of Armenia, which, with the restoration after its six-hundred-year break of statehood, turned to the arsenal of historical symbolism, is based on symbols that date back to the times of ancient kingdoms. The first attribute of its national selfdetermination was the flag enshrined in the Law of August 24, 1990: a rectangular panel with three equal horizontal stripes - red, blue and orange (1:2 ratio of width and length of the flag). In the popular interpretation, the red flag means bloodshed in the struggle for independence, blue means the unchanging nature of the earth, and orange means the industriousness of the Armenian people ${ }^{2}$.

On July 1, 1991, a resolution of the Verkhovna Rada of the Republic approved the new State Anthem of Armenia. The anthem of the Republic of Armenia from 1918 to 1920 (the so-called first republic) was taken as its basis). On September 21, that year, a nationwide referendum was held, which resulted in the decision to withdraw from the USSR, and September 23 has been recognized as the official Independence Day.

The acquisition of state sovereignty required its immediate consolidation in the heraldic space. The result of the public discussion was the resolution of the Supreme Council of Armenia of April 19, 1992 approving the State Emblem. Its ideology is based on the national symbols of the Armenian people: in the center on the shield is the two-peak Mount Ararat with Noah's Ark, at the foot of the mountain are the silver waves of Van Lake; they are surrounded by the arms of four royal dynasties - Artashesid, Arshakuni,

${ }^{2}$ Гречило А. Герби новопосталих держав. Пам'ятки Украӥни: Історія та культура. 2001. № 2. C. 163. 
Bagratuni and Rubinians (Cilicia); the shield is supported by an eagle and a lion - symbols of the power of spirit and power, and under the shield depicts a sword, a broken chain (symbols of the people's struggle for freedom and independence), a feather, ears (embodiment of creative talent, peacefulness) and a ribbon in national colors ${ }^{3}$.

Thus, the symbolic attribution of Armenian sovereignty came about with wide public resonance and ran along the trajectory: «flag - anthem declaration of independence - coat of arms - Constitution», which allows to speak about the subjectivity of state symbols as an agent of political transit.

In almost similar scenarios, the symbolic spaces of Georgia and Azerbaijan were reformatted. The post-Soviet symbolic creation of the 1990s in these countries relied on centuries-old historical and national traditions and was inspired by the heraldic aesthetics of the democratic republics of 1918-1920.

In general, the processes of symbolic attribution of state sovereignty of the former Soviet republics of the Caucasus region can be characterized as occurring against the backdrop of lively civic debate. Although, in most cases, the introduction of new symbols did not encourage political transformation, but only anchored them in the civic symbolism of the country.

The national symbolism in the processes of state self-determination of the people of Moldova played a fundamentally different role. The period between the proclamation of sovereignty and the adoption of the Declaration of Independence (June 23, 1990 - August 27, 1991) became the defining and intense one on the path of rebuilding the national symbolic space of the republic. Chronologically, this process is marked by such moments as the Latinization of the Moldovan alphabet (August 31, 1989), the change of flag (April 27, 1990), the proclamation of sovereignty (June 23, 1990), the introduction of the post of president (September 3, 1990), adoption of the state emblem (November 3,1990), change of the official name of the state (May 23, 1991), declaration of independence (August 27, 1991). As we can see, the starting point in the process of systemic transformation was the adoption of laws on August 31, 1989 «On the status of the state language of the Moldavian SSR» and «On the return of the Moldovan language to Latin graphics» by the supreme legislative body of the Moldavian SSR, which granted the status of the state language to Romanian and enshrined the return of its Latinized version.

The proclamation of state sovereignty, which took place on June 23, 1990, was also preceded by the most important, in the context of symbolic self-determination of statehood, the decision to adopt a new state flag. On April 27, 1990 the Supreme Council of the Moldavian SSR adopted the Law

\footnotetext{
${ }^{3}$ Цугунян М. 3 історії герба та прапора республіки Вірменії. Знак. 1994. № 7. С. 9.
} 
on the State Flag - blue-yellow-red tricolor. The Regulation on the State Flag, approved by the Decree of the Parliament No. 17 - XII of May 12, 1990, reads: «The State Flag of the Republic of Moldova - tricolor - is the official symbol of the Republic of Moldova. It symbolizes the past, present and future of the Moldovan state, reflects its democratic beginnings, historical tradition ${ }^{4}$.

An important part of the process of preparation and declaration of independence was the restoration of traditional national symbols. Thus, on September 3, 1990, two months after the new flag was adopted, simultaneously with the establishment of the post of President of the country (Decree of the Supreme Council of the Moldovan SSR No. 251 - XII of September 3, 1990), the Supreme Council of the MSSR chooses as an emblem the ancient Moldavian symbol - the head of the tour'. The Regulation on the State Emblem of the Republic of Moldova, approved by the Law of November 3, 1990, states: «The State Emblem of the Republic of Moldova is a horizontal cross-section, in the upper part of which is a red field, in the lower part - blue. The center of the shield depicts the head of a bison, between the horns of which is an eight-ray star» ${ }^{6}$.

Further changes in the civic symbolism of the republic took place on May 23, 1991, when the name of the country was officially changed by Law of the Supreme Council of the MSSR No. 589-XII. The Soviet Socialist Republic of Moldova was renamed the Republic of Moldova.

In our view, Moldova's declaration of independence, which took place in response to the August events of 1991, can be regarded as the result of processes of national and state self-determination, an integral part of which was the reformatting of its symbolic space.

On August 27, 1991, the Parliament of the Republic adopted the Declaration of Independence of the Republic of Moldova. This date was declared a national holiday - Moldova Independence Day. In 2003, it was renamed Republic Day.

With the adoption of the Constitution of the Republic of Moldova on 29 July 1994, the status of national symbols was finally affixed to the flag, coat of arms and anthem (Article 12). However, it should be noted that the State Anthem was introduced the last among the elements of the symbolic

${ }^{4}$ Государсвенный флаг Республики Молдова: Положение о Государственном флаге, утвержденное Постановлением Парламента №17-XII от 12 мая 1990 года). Президентура Республики Молдова: веб-сайm. URL: http://www.president.md/simb.php?lang=rus.

${ }^{5}$ Про Державний герб Республики Молдова: Закон РМ № 337-XII от 3 ноября 1990 г. Президентура Республики Молдова: веб-сайт. URL: http://www.president.md/ simb.php?lang=rus.

${ }^{6}$ Положение о Государственном гербе, утвержденное Законом Республики Молдова № 337-XII от 3 ноября 1990 года. Президентура Республики Молдова: веб-сайт. URL: http://www.president.md/simb.php?lang=rus. 
complex of attribution in the symbolic space of the country. By a law of July 22, 1995, the song «Limba noastră $»$ on the poems of Alexei Mateevich (1.2.5.8.12. Stanza) and the music of Alexander Christa in arrangement by Valentin Dingy was officially approved as anthem ${ }^{7}$.

Thus, the example of Moldova proves that the process of symbolic attribution of state sovereignty can become a real locomotive of systemic transformations in the political and spiritual sphere of society and contribute to the political transit to the democratic channel.

\section{Specificity of symbolic attribution of state sovereignty in Central Asian countries as a marker of consolidation of authoritarian tradition}

The attribution of independence in the Central Asian and Kazakhstan republics was somewhat different. First of all, in the symbols of state sovereignty, the traditional Muslim symbolism for these territories has received a new, albeit hidden, sound.

Given that the tradition of symbolically presenting subjects of sociopolitical relations, such as the European heraldic sign systems, has not historically been formed in the countries of the Islamic circle, the history of heraldry in the post-Soviet region de facto begins in Soviet times. After all, the final formation of nation-states in this territory in modern borders dates back to the 1920's. That is why, faced with the need for symbolic selfdetermination of state sovereignty, the new states of Central Asia, without being able to turn to historical models, chose the path of conceptual symbolization «from a blank sheet.» The most significant in this aspect was the experience of Uzbekistan.

Having proclaimed its sovereignty on August 31, 1991, the Republic of Uzbekistan actively began to create its own symbolic complex of attribution. On November 18, 1991, the Supreme Council of the Republic of Uzbekistan approved a new state flag following the results of the competition ${ }^{8}$. The green-blue-white palette and the heraldic signs on the flag are interpreted by the official Uzbek heralds as follows: blue is a symbol of eternal sky and water; white - peace, wishes for a happy journey, purity of thoughts and actions; green is the color of nature, new life and fertility; red means vitality. The moon is interpreted as a sign of independence, the stars as a symbol of a cloudless sky, and their number is associated with historical traditions and the ancient solar calendar ${ }^{9}$. However, it is indisputable that under this secular

${ }^{7}$ О Государственном гимне Республики Молдова: Закон РМ № 571-XIII от 22 июля 1995 года. Президентура Республики Молдова: веб-сайт. URL: http://www.president.md/ simb.php?lang=rus.

${ }^{8}$ О Государственном флаге Республики Узбекистан: Закон Республики Узбекистан. Правда Востока. 1991. 27 ноября. С. 1.

${ }^{9}$ Гречило А. Символи нових незалежних держав. Пам'ятки Украӥни: Iсторія та культура. 2001. № 4. С. 135-141. 
and sufficiently poetic description are hidden basic symbols traditional for the Muslim world, such as green color, stars, new moon, etc.

On June 2, 1992, the Parliament of the Republic approved the State Emblem of the RU. Its semantics are in harmony with the State Flag palette and are based on traditional Uzbek culture symbols (humorous bird with wings that are considered the embodiment of the idea of happiness and love, cotton, wheat) and at the same time include Muslim ornamentals (octagon, crescent, star). On December 10 of the same year, a separate law approved the anthem of the RU: «Get up, my free country.» However, despite the efforts of the official experts to mark the new attributes of Uzbekistan's sovereignty as original, the genetic connection of the visual decision of the new state symbols with the Soviet heraldic stylistics is striking.

In general, it should be noted that the symbolic process in this country was not actualized in the broad civil debate, but passed under the patronage of the state, creating a model more characteristic of the political culture of the Soviet society. New symbols of independence, without becoming subjects of political discourse, played the role of signs that only fixed the status quo.

Similar scenarios of symbolic consolidation of statehood, the format of which can be defined as «symbolic formation from the mountain», have been implemented in other republics of the region - Turkmenistan, Kirghizia. All of them slowly changed the semantics of the new signs of statehood. With the help of specially formed collectives, the complex esoteric motifs that appeared in the symbolic expanses of the countries in the early 1990s were gradually replaced by the associative symbolism (cotton, ears, book, mountain outline, etc.) that characterized the Soviet heraldic tradition.

The most active search for forms of a new symbolic presentation of state sovereignty of the countries of the region unfolded in the Republic of Kazakhstan.

On December 10, 1991, the Kazakh SSR was renamed the Republic of Kazakhstan. And on December 16, 1991, Kazakhstan declared its independence.

After the collapse of the USSR, in Kazakhstan tenders were announced for projects of new national symbols, which received 453 variants of the flag and 245 sketches of the coat of arms ${ }^{10}$. On June 4, 1992, the Verkhovna Rada of the Republic of Kazakhstan approved laws on the state emblem and flag. Their semantics were radically different from the Soviet ones and were built on the combination of gold and blue with the motives of the sun's rays. We will add that, the symbolic complex of attribution of the Republic of

\footnotetext{
${ }^{10} \mathrm{Ibid}$
} 
Kazakhstan is the result of complex collective work, which clearly reflected on its conceptual foundations and aesthetic manifestations.

Summarizing the overview of the Central Asian region, we note that the formation of symbolic attribution complexes in its territory followed the model from above. At the same time, being the result of the author's developments, the new symbols of state sovereignty fully retained their loyalty to the Soviet heraldic style (except Kazakhstan). Thus, state symbolism in the Central Asian republics did not become a detonator of systemic changes, but only a reflection of them.

\section{State symbols as a reflection of the political order in post-totalitarian Belarus and Russia: lessons for Ukraine}

Particular attention should be paid to the role of national symbols in the formation of new political regimes in Belarus and the Russian Federation.

The history of the symbolic self-determination of Belarus was extremely dramatic. On July 27, 1990, the Supreme Council of the BSSR adopted a Declaration of State Sovereignty following a heated political debate that was ongoing in the Parliament. After the August events of 1991, it was decided to grant the document the status of a constitutional law. On the same day, on August 25, 1991, a resolution was issued to suspend the Communist Party of Belarus. And on September 19, 1991, the Belarusian Soviet Socialist Republic was renamed into the Republic of Belarus and the national symbols were changed ${ }^{11}$. The independent state of Belarus has received a new coat of arms and flag. The semantics of these symbols were based on the historical traditions of the Belarusian territorial heraldry, which is genetically related to the heraldic systems of the Grand Duchy of Lithuania and the Commonwealth. It was built on the traditional Belorussian culture of red and white color and the symbolic figure of the rider Pogoni. On March 15, 1994, the transformations that took place in the symbolic space of Belarus were enshrined in its Basic Law.

However, the political changes that followed the 1994 presidential election, following which President Lukashenko held the office of head of state, have become more active in trying to return Soviet-era symbols to the country's civic symbolism. A campaign to discredit the revived national symbolism as one that embodied the collaborative movement on the lands of Belarus during the period of German-fascist occupation (1941-1944) began).

11 О государственном флаге республики Беларусь: Закон Республики Беларусь от 19 сентября 1991 г. № 1090-ХІІ. Ведомости Верховного Совета Республики Беларусь. 1991. № 30. Ст. 493; Об утверждении эталона Государственного герба Республики Беларусь и Положения о Государственном гербе Республики Беларусь: Постановление Верховного Совета Республики Беларусь от 10 декабря 1991 г. № 1294-XII. Ведомости Верховного Совета Республики Беларусь. 1992. № 1. Ст. 13. 
Given that traditional national symbols were negatively perceived by Belarusian society, in particular by veterans' organizations, and against the background of a rather indifferent attitude of the political establishment to the problems of state symbols, the newly elected President of the Republic made the decision to change the topic for national discussion. On May 14, 1995, at the initiative of the President, a referendum was held in Belarussia on granting the Russian language the status of a state language, approving new state flags and emblems, as well as supporting the actions of the head of state aimed at economic integration with the Russian Federation. On all issues, a positive decision was made and the traditional Belarusian state flag and coat of arms were deprived of the status of state one ${ }^{12}$. And on May 16, 1995, the white-red flag was removed from the roof of the Government House. According to eyewitnesses, the cloth was torn to shreds «for souvenirs». From this moment, the national bicolor and coat of arms of the pursuit is used by the democratic opposition of Belarus as symbols of the struggle against the Lukashenko regime. Thus, with the change of political regime, the former state symbols of the Republic of Belarus have become political.

According to A. Grechilo, in the conditions of frantic propaganda the results of the referendum were predicted ${ }^{13}$. On this basis, a presidential decree of June 7, 1995 approved new symbols, which are essentially modified symbols of the BSSR. Thus, Belarus became the only former USSR republic, which with a small correction restored the attributive complex of the Soviet era. With the approval of Presidential Decree No. 350 of 02.07.2002, the new text of the State Anthem of Belarus, which was still in existence in the wording of 1955, finally formed the basic triad of national symbols, and on July 5, 2004 the Law of the Republic of Belarus «On State Symbols of the Republic of Belarus» (No. 301-3), coat of arms and anthem have been finally confirmed.

Tectonic changes in the process of political transit in the 1990s and 2000s have undergone the civil symbolosphere of the Russian Federation. After all, it was influenced by two multi-vector trends, determined by the need to acquire its own identity on the one hand and the need to assure the succession of the status of a country - a geopolitical and geocultural leader on the other.

12 Об итогах голосования на республиканском референдуме 14 мая 1995 года: Сообщение Центральной комиссии Республики Беларусь по выборам и проведению республиканских референдумов. Центральная комиссия Республики Беларусь по выборам и проведению республиканских референдумов: веб-сайт. URL: http://www.rec.gov.by/refer/ref1995resdoc.html.

${ }^{13}$ Гречило А. Герби новопосталих держав. Пам'ятки Украӥни: Історія та культура. 2001. № 2. C. 168. 
The liberalization of the Soviet political regime, which took place in the late 1980s, helped to bring the issue of national Russian symbols to the epicenter of public debate. The fiercest debate has been around the new flag. Their participants were divided into three groups. Representatives of the first, the most radical, strongly advocated the need to revive the blackyellow-white flag with monarchical symbolism. The second group tended to abandon the Soviet symbols. However, the position that insisted on the restoration of the white-blue-red flag was won, since it was defined by most citizens as national. During the dramatic events of the August putsch, national Russian tricolor was widely used by forces opposed to the State Emergency Committee (SEC). On August 22, 1991 by the Decree of the Supreme Council of RSFSR «the historical flag of Russia» was recognized as «the official State Flag of the Russian Federation ${ }^{14}$. And as early as November 1, 1991, it was approved in the status of the state flag of the RSFSR at the legislative level ${ }^{15}$.

The end of 1991 was marked by another important change in the symbolic space of Russia: on December 25, 1991, the name «RSFSR» was legally changed to «Russian Federation».

If the new flag was organically incorporated into the civic symbolosphere of a democratic Russia, then the issue of the state emblem was rather difficult, which affected the timing of its setlement.

It is clear that with the acquisition of the new coat of arms radical changes come not only in the socio-cultural sphere, alleys and office. Firstly, the emblem of the RSFSR continued to be used after the renaming of the state itself on December 25, 1991, until May 1992, when a number of amendments was not made to the Constitution and Basic Law of the RSFSR. And only on December 6, 1993 «... with the aim of restoring the historical symbolism of the Russian statehood», as well as «bearing in mind that the State Emblem of the RSFSR lost its symbolic meaning», a fundamentally new heraldic concept was introduced by the Presidential Decree. The Decree stated: «1. The State Emblem of the Russian Federation is an image of a golden two-headed eagle placed on a red heraldic shield; above the eagle three historical crowns of Peter the Great (above the heads - two small and above them - one larger); in the paws of an eagle - the scepter and the state;

14 Об официальном признании и использовании Национального флага РСФСР: Постановление Верховного Совета РСФСР от 22 августа 1991 г. № 1627/I-I. Caŭm Конституции Российской Федерации. URL: http://constitution.garant.ru/history/.

${ }^{15}$ Об изменениях и дополнениях Конституции (Основного Закона) РСФСР: Закон РСФСР от 1 ноября 1991 г., принят пятым (внеочередным) Съездом народных депутатов PCФСР, (прекратил действие). Сайт Конституции Российской Федерации URL: http://constitution.garant.ru/history/ussr-rsfsr/1978/zakony/183125. 
on the chest of an eagle on a red shield is a rider striking with a spear. 2. Reproductions of the State Emblem of the Russian Federation in the onecolor variant, as well as its reproduction in the form of the main figure two-headed eagle are allowed $\gg{ }^{16}$.

However, this dramatic return to imperial discourse was not supported by all Russians. For example, in the debate that began in the late 1990s around the issue of state symbols, many supported the idea of returning to the symbolism of socialist Russia. On December 20, 2000, the Federal Constitutional Law «On the State Emblem of the Russian Federation» was promulgated, which put an end to disputes. The obvious imperial semantics of the Russian emblem in the official interpretation takes on the following meaning: the three crowns represent the sovereignty of both the entire Russian Federation and its constituent entities, and the scepter with the state holding the two-headed eagle in its paws symbolizes the state power and united state ${ }^{17}$. Thus, in general, the coat of arms of the Russian Federation is a reflection of the foundations of the political culture of Russian society, the basic components of which are the cult of great power, piety before the authorities, etc.

Indicative in terms of the characteristics of those processes that take place in the civic symbolism of post-Soviet Russia, is also the story of her acquisition of a new anthem. Today's State Anthem of the Russian Federation - the resuscitated Soviet anthem for the music of Alekdandr Alekdandrov - was approved on December 8, 2000 by a separate Federal Constitutional Law signed by the newly elected head of state V. Putin ${ }^{18}$.

The previous State Anthem of the Russian Federation (1990 - 2000) M. Glinka's «Patriotic Song», which did not receive poems as a state symbol - failed to gain unquestionable popularity in the general public.

With the change of leadership of the country in 2000, which marked the return to the ideological discourse of the theme of national patriotism and the continuity of traditions of strong imperial statehood, the question of changing the main musical symbol of the country was put on the agenda. Based on the data of many sociological polls and noting the low popularity of the «Patriotic Song», the State Duma of the Russian Federation adopts a draft of the law «On the National Anthem of the Russian Federation» on

${ }^{16}$ О Государсвенном гербе РФ: Указ Президента РФ № 2050 от 30 ноября 1993 г. Официальный сайт Президента России. URL: http://president.kremlin.ru.

17 Государсвенная символика РФ. Государственная символика: веб-сайт. URL: http://www.statesymbol.ru.

${ }^{18}$ О Государственном гимне Российской Федерации: Федеральный конституционный Закон №3-ФКЗ от 8 декабря 2000 г. Официальный сайт Президента России. URL: http://document.kremlin.ru/doc.asp? $\mathrm{ID}=5163 \& \mathrm{PSC}=1 \& \mathrm{PT}=3 \& \mathrm{Page}=5$. 
March 10, 1999 in the first, and December 8, 2000 - in the third, final reading. On December 20, 2000, the law was overwhelmingly approved by the Federation Council: the music of A. Aleksandrov (USSR anthem) was approved as the tune of the anthem, and poems were sought. On December 25, 2000, Putin created a working group to consider proposals for the anthem text. In the period from December 2000 to February 2001, 5 drafts were tabled in the country's parliament on the subject. Among them was a poem by S. Mikhalkov and G. El-Registan. This modernized version of the Soviet anthem was supported by Putin. It was adopted as the text of the official anthem of the Russian Federation on March 7, 2001.

Summarizing the history of the formation of the symbolic complex of attribution of the Russian Federation, it can be noted that it is a rather eclectic formation, consisting of fragments of various political discourses (monarchical, Soviet, national-patriotic), characteristic of post-Soviet Russia and explicitly amateurish and the geopolitical domination of Putin's Russia.

\section{CONCLUSIONS}

Familiarity with the main milestones of the formation of new attributive complexes in the new post-Soviet countries allows us to make some generalizations about the place and role of state symbols in the processes of independence and statehood and to identify, on this basis, the relationship between a particular model of formation of a symbolic complex, the attribution of its symbolic complex, filling and specifics of newly created political regimes.

So, first, according to the functional load in the processes of political transit several varieties of symbolic attribution complexes (SAC) can be distinguished, namely:

a) SAC, whose constituents are symbols - catalysts, where the latter can be fully considered the basis of the symbolic matrix of political transformations (Baltic Republics, Moldova, Georgia). We will add that the main functions of the symbols - catalysts for the transition period are political mobilization and integration of public communities.

b) SAC, whose constituents are symbols - retainers, which act as reverberators of already made systemic transformations (Central Asian countries). This model of SAC formation foresees, first of all, the reliance on the state symbolism of the function of legitimizing the newly emerging political regime of authoritarian nature.

c) SAC, the dominant component of which is represented by symbols indicators. They serve as markers of social inquiry in the market of spiritual and ideological production and perform, above all, the function of political 
identification (Belarus, the Russian Federation, partly the republics of the Caucasus and the Transcaucasia).

Second, the form and semantic load of the SAC formed in the post-Soviet space can be divided into those based on:

a) the return of state symbols of the pre-Soviet period (Baltic countries, Russian Federation (in part));

b) national symbols and national symbols of the postwar period (Caucasus and Transcaucasian countries, Moldova (partially));

c) for symbols - copyright work (Central Asian countries);

d) for partial resuscitation of Soviet heraldic stylistics (Russian Federation, Belarus).

Finally, let's note the following. The emergence of new independent states on the political map always requires a radical review of the foundations of their symbolic attribution complexes. As the experience of the republics of the former USSR showed, the ways and dramaturgy of the SAC formation are clearly linked to political and socio-cultural factors. Thus, in the European and Caucasian countries of the post-Soviet space, where today democratic and hybrid regimes were formed, despite the notable enough ideological resistance from the party nomenclature, the turn to historic national symbols took place in the process of independence. On the contrary, the authoritarian republics of Central Asia and Kazakhstan have constructed SACs of their sovereignty on wholly newly created (though not beyond national or cultural) symbols. And the heraldic-semantic and conceptual eclecticism of the SAC of the Russian Federation and Belarus clearly indicates the main tendencies of political development of these countries at the present stage.

Equally revealing was the process of rebuilding the symbolic complex of Ukraine's attribution. Given that in today's political realities and geopolitical challenges, these issues need to be thoroughly considered and deserve some basic research ${ }^{19}$, let us note only that the systemic changes that our country has been experiencing in recent years were also reflected in the content load of the symbolic attribution complex, which went from the symbols of the liberation struggle through a period of emblematic official protocols to the transformation of the Ukrainian society into an instrument of consolidation of political nation. All this reinforces our hopes for the irreversibility of the results of democratic transit that our society has embarked on

${ }^{19}$ Мамонтова Е. В. Державний протокол та церемоніал як символічний інструмент забезпечення процесу публічної комунікації: витоки, структура, нормативноорганізаційні засади: монографія. Одеса: Друкарський дім, 2011. 480 с. 


\section{SUMMARY}

The work on the material of the countries of the former Soviet Union shows the place and role of state symbols in the processes of independence and statehood. The interdependence of political and socio-cultural determinants of social development is determined on the basis of identification and comparison of characteristic features of symbolic selfdetermination of the Baltic countries, Caucasus, Central Asia, Moldova, Belarus, and the Russian Federation. The peculiarities of the symbolic attribution of state sovereignty as a factor of political transit are revealed and an assessment of its state-building potential is given. The main sources of symbolization of the post-totalitarian era are outlined: national and spiritual symbolism; state (imperial) symbolism of the pre-Soviet period; republican symbols of the postwar period; resuscitation of Soviet heraldic stylistics; artificial symbolism as a result of copyright. The relationship between functional and semantic loading of state symbols with the trajectory of political transit is shown. The specific character of the retainer symbols, which act as a retractor of the already implemented systemic transformations and provide the function of legitimizing the newly emerging political regime of authoritarian character, is outlined. Characteristics of symbols - indicators that perform the function of political identification and serve as markers of social inquiry in the market of spiritual and ideological production in hybrid modes are characterized. It is proved that to provide a democratic vector of political transit symbols - catalysts are capable, which in the processes of state formation perform the function of political mobilization and integration of public communities. It is argued that the irreversibility of democratic change can be ensured not only by the development of democratic institutions and formal perceptions of democratic rules and procedures, but also by the consolidation of democratic values at the level of the cultural code. The last task can be realized only under the influence of cultural and value factors, among which the important place belongs to symbolism.

\section{REFERENCES}

1. Государсвенная символика РФ. Государственная символика: веб-сайm. URL: http://www.statesymbol.ru.

2. Государсвенный флаг Республики Молдова: Положение о Государственном флаге, утвержденное Постановлением Парламента № 17-XII от 12 мая 1990 года). Президентура Республики Молдова: вебcaüm. URL: http://www.president.md/simb.php?lang=rus.

3. Гречило А. Герби новопосталих держав. Пам'ятки Украӥни: Історія та культура. 2001. № 2. С. 162-167.

4. Гречило А. Символи нових незалежних держав. Пам'ятки України: Історія та культура. 2001. № 4. С. 135-141. 
5. Мамонтова Е. В. Державний протокол та церемоніал як символічний інструмент забезпечення процесу публічної комунікації: витоки, структура, нормативно-організаційні засади: монографія. Одеса: Друкарський дім, 2011. 480 с.

6. О Государсвенном гербе РФ: Указ Президента РФ № 2050 от 30 ноября 1993 г. Официальный сайт Президента России. URL: http://president.kremlin.ru.

7. О Государственном гимне Республики Молдова: Закон РМ №571-XIII от 22 июля 1995 года. Президентура Республики Молдова: веб-сайт. URL: http://www.president.md/simb.php?lang=rus.

8. О Государственном гимне Российской Федераџии: Федеральный конституционный Закон №3-ФКЗ от 8 декабря 2000 г. Офищиальный сайт Президента России. URL: http://document.kremlin.ru/ doc. asp? ID $=5163 \& \mathrm{PSC}=1 \& \mathrm{PT}=3 \& \mathrm{Page}=5$.

9. О государственном флаге республики Беларусь: Закон Республики Беларусь от 19 сентября 1991 г. № 1090-XII. Ведомости Верховного Совета Республики Беларусь. 1991. № 30. Ст. 493.

10. О Государственном флаге Республики Узбекистан: Закон Республики Узбекистан. Правда Востока. 1991. 27 ноября. С. 1.

11. Об изменениях и дополнениях Конституции (Основного Закона) РСФСР: Закон РСФСР от 1 ноября 1991 г., принят пятым (внеочередным) Съездом народных депутатов РСФСР, (прекратил действие). Сайт Конституции Российской Федеращии. URL: http://constitution.garant.ru/history/ussr-rsfsr/1978/zakony/183125.

12. Об итогах голосования на республиканском референдуме 14 мая 1995 года: Сообщение Центральной комиссии Республики Беларусь по выборам и проведению республиканских референдумов. Центральная комиссия Республики Беларусь по выборам и проведению республиканских референдумов: веб-сайт. URL: http://www.rec.gov.by/refer/ref1995resdoc.html.

13. Об официальном признании и использовании Национального флага РСФСР: Постановление Верховного Совета РСФСР от 22 августа 1991 г. № 1627/I-I. Сайт Конституции Российской Федерации. URL: http://constitution.garant.ru/history/.

14. Об утверждении эталона Государственного герба Республики Беларусь и Положения о Государственном гербе Республики Беларусь: Постановление Верховного Совета Республики Беларусь от 10 декабря 1991 г. № 1294-XII. Ведомости Верховного Совета Республики Беларусь. 1992. № 1. Ст. 13.

15. Положение о Государственном гербе, утвержденное Законом Республики Молдова № 337-XII от 3 ноября 1990 года. Президентура 
Республики Молдова: веб-сайт. URL: http://www.president.md/ simb.php?lang=rus.

16. Про Державний герб Республики Молдова: Закон РМ № 337XII от 3 ноября 1990 г. Президентура Республики Молдова: веб-сайт. URL: http://www.president.md/simb.php?lang=rus.

17. Про изменение статей 168 та 169 Конституции Литовськой ССР: Закон Литовской РСР от 18.11.1988 г. Советская Литва. 1990. 19 ноября.

18. Цугунян М. 3 історії герба та прапора республіки Вірменії. Знак. 1994. № 7. С. 9.

Information about the author: Mamontova E. V., Doctor of Political Sciences, Professor, Professor at the Department of Political Theories of the National University «Odessa Law Academy» 2, Academichna str., Odesa, 65009, Ukraine 


\section{PROTEST SOCIO-POLITICAL MOVEMENTS AND ORGANIZATIONS AND THEIR TRANSFORMATION IN THE LATE 1980S. IN THE MODERN COUNTRIES OF THE VISEGRAD GROUP}

\section{Koltsov V. M.}

\section{INTRODUCTION}

The consequence of the introduction of the concept of democratization and modernization of socialism incorporated in the processes of «perestroika» as an alternative to the political regime which, being «obsolete», took place in the second half of the 1960s, as well as the systemic crisis in the socio-economic and socio-political spheres was that from the late 70's, but more from the middle - the second half of the 80's of the twentieth century in Poland, Hungary and Czechoslovakia the structural and organizational network of protest began to expand, which as a result turned out to be a variation of the transition from dissidence to opposition (in the «resistance - dissidence - opposition» triad).

However, such a transition from dissidence to opposition was not straightforward and one-vector, but was mainly carried out in the categories of protest socio-political movements and organizations, which eventually substantially and conceptually transformed into political opposition, in particular through the prism of its understanding as a form of social / sociopolitical protest.

In this context, the ideas of J. Rothschild, M. Sczabo, and G. Schopflin that the modern countries of the Visegrad Group, until at least the 1980s, were not characterized by widespread practice of protest socio-political movements - that is, processes of civil society - deserve attention, mobilized for the support of specific socio-political demands and non-institutionalized or partially institutionalized collective actions that sought to mobilize broad public support in order to achieve the publicly-formed goals and requirements of workers. That is, as Jenkins points out, no social movements were created in the region until a certain period of time, which were collective actions, envisaged deliberate actions to change individual and social institutions and non-institutional forms of political participation that would be characterized by such attributes (as ideology) conceptual structure 
based on an awareness of the importance of collective action, organization (a way of coordinating collective action and the environment (the participation of various actors in the design of socio-political actions that target the protest groups ${ }^{1}$.

It was only in the aftermath of the events of the partial liberalization of the communist regime in the 1960s, as well as during and on the basis of the socio-political and socio-economic crisis of the early and mid-1980s that made leadership structures immobile and subordinate conservative bureaucratic interests (less so in Czechoslovakia, where the communist regime held on to a comparatively more coercive state-party apparatus and more pronounced support for the Soviet Union), in the midst of dissent and other social groups (and communist parties) matured at least some chance of protest against the regime of «real socialism» ${ }^{2}$. Although these opportunities were never institutionalized, they were accordingly dependent on the «goodwill» of the Soviet and national political regimes, as well as on the regional patterns of new mobilization perspectives embodied in the form of a protest culture aimed at democratization. Thus, the emergence of political opportunities in Poland, Czechoslovakia and Hungary for the mass mobilization and development of protest culture was driven primarily by the general trend of the decline of the communist regime in the region and the response of the national socio-political environment.

\section{Formation and functioning of protest socio-political movements in the modern countries of the Visegrad Group}

The formation, functioning and consequences of protest socio-political movements in the modern countries of the Visegrad Group were quite different, and therefore they require both a consistent separate review and a consolidated comparative analysis. It must begin with the observation that the phenomenon of socio-political movements is quite different from the phenomenon of dissidence (even including it) ${ }^{3}$. And not only in the achieved results, but also structurally and systematically. Thus, dissidence emerged as a reaction to the collapse of the «revisionist project» of the creation of «socialism with a human face» and to the «strict» conservatism of the Brezhnev era. Accordingly, dissidence was positioned primarily as a form of

\footnotetext{
1 Jenkins R. Movements Into Parties: The Historical Transformation of the Hungarian Opposition. Program on Central and Eastern Europe Working Paper Series. 1992. No. 25. $80 \mathrm{p}$.

${ }^{2}$ Batt J. The End of Communist Rule in East-Central Europe. Government and Opposition. 1991. Vol. 26. No. 3. P. 368-390.

${ }^{3}$ Bernhard M. Civil Society and Democratic Transition in East Central Europe. Political Science Quarterly. 1993. Vol. 108. No. 2. P. 307-326.
} 
moral conviction addressed to challenge the position of the «party-state» and its activities ${ }^{4}$. In turn, and in view of the collapse of the concept of revisionist Marxism and the «overflow» of dissidence into the sphere of human and citizen protection, protest socio-political movements were more constructed on the logic and strategies of opposition resistance. It turned out that, relying primarily on the «forces» of society, for the first time in the conditions of «real socialism» regimes, they began to put pressure on political power and the party-state over how they functioned and were supposed to function. Moreover, the protest socio-political movements resorted to rhetoric about the need to reform the existing systems of regimes of «real socialism», in particular the instruments of influence of the contradictions of social resistance and opposition, which first felt and exploited the existing contradictions. This, according to L. Kolakovsky, meant that political protest groups concealed themselves as instruments and mechanisms of opposition, as they resorted to a «reformist orientation in the sense of believing in the possibility of effective, gradual and partial pressure», in particular with a view to a «long-term perspective» social and national liberation ${ }^{5}$ and towards a long-term strategy for the behavior of socio-political movements ${ }^{6}$. Accordingly, the appearance of sometimes in the late 70's, but mostly in the middle - the second half of the 80's of the twentieth century of protest groups with outlined ideological and programmatic postulates meant the transformation of the very phenomenon of protest from a format of dissidence into a format of political opposition incorporated in the form of socio-political movements ${ }^{7}$.

For the first time protest / opposition socio-political movements began to take shape in Poland in the late 1970s, marking the emergence of the first opposition (as a form of social / political protest) in the Soviet bloc. For example, in 1976, the first step in self-liberalization of civil society in Poland emerged, as a result of the failure of the workers' strike resulted in the first attempt under the communist regime to implement the opposition rather than the dissident line of resistance. The most important social actor in creating such a protest was the Workers Protection Committee (KOR). In addition, other protest groups with highly diversified political or ideological orientations competed with the Committee. So, over time, the largest «public space» in the region for protest / opposition activity was generated in

${ }^{4}$ Rakovski M. Towards an East European Marxism. New York: St. Martin's, 1978. P. 105.

${ }^{5}$ Kolakowski L. Hope and Hopelessness. Survey. 1971. Vol. 17. P. 48.

${ }^{6}$ Michnik A. The New Evolutionism. Survey. 1976. Vol. 22. P. 274.

7 Кольцов В. Вплив протестних суспільно-політичних рухів і організацій на формування політичної опозиції в сучасних країнах Вишеградської групи (70-80 роки ХХ століття). Молодий вчений: науковий журнал. 2017. № 6 (46). С. 28-32. 
Poland, which in fact initiated the process of limiting the dependence of public interests on the state. In this space, the leading protest / opposition movement was the Solidarity movement, which even though it was weakened in the early 1980s, in particular by the pressure of the communist regime, soon revealed that the party-state was simply not able to reform successfully the «stagnant» Polish economy, and therefore completely isolate the protest / opposition, first and foremost in the expression of Solidarity, from its sources of social support. Moreover, it was the organizational and political experience of members of the protest / opposition Solidarity that had a tremendous impact on the further deployment of the political process in Poland. The culmination was the «contract» between the authorities and the socio-political movements, which eventually peacefully during the February-April 1989 roundtable negotiations and the partially free parliamentary elections in June 1989 led to the collapse of the «real socialism» regime and the democratization of Poland.

The result of these processes is that: - independent trade unions are legalized; the election of the president-elect was first introduced by parliament, and subsequently nationwide (with the cancellation of the General Secretariat of the Polish United Workers' Party); a bicameral parliament within the Seimas and the Senate was formed; incorporated the practice of the «Contracted Seimas» (a communist V. Jaruzelsky was elected the president, a prime minister - a representative of «Solidarity» T. Mazowiecki, and there was an agreement on the distribution of the maximum number of mandates for «Solidarity» with the predominance of the opposition regime of social and political movement.

In the course of the processes exemplified in Poland, as well as on the basis of their experience, the formation of protest / opposition movements and anticommunist transformations in other countries of the modern Visegrad Group and in the USSR as a whole began (often this is the basis of the question of the primacy of not the «Gorbachev effect» but «The effect of Poland»), which led to the collapse of the communist regime in the region ${ }^{8}$.

Thus, the case of Poland demonstrated and signaled that processes were possible: peaceful/concerted delegitimization and change of political regime; maneuvering and legalization of political protest groups; ensuring freedom of the press, speech, conscience and association; political participation and

${ }^{8}$ Kenney P. A Carnival of Revolution: Central Europe 1989. New Jersey: Princeton University Press, 2002. P. 2. 
electoral competition ${ }^{9}$. In turn, Poland's «exclusivity / uniqueness» was due to the fact that: a) protests and opposition in this country were constructed on the basis of the experience of earlier "waves» of the working and intellectual opposition to the communist regime ${ }^{10}$; b) Communism in this country has never been interpreted as a «natural» phenomenon, but rather as a phenomenon implanted by Poland's «historical enemy» - backward Russia - making the legitimacy of the communist regime positioned as a threat to Polish national sovereignty ${ }^{11}$; c) the communist regime did not outline the current and urgent sociopolitical divisions existing in Poland after World War $\mathrm{II}^{12}$, and therefore Poland did not get used to positioning Russia artificially as a «friend» and Germany as an «enemy»" ${ }^{13}$, as a result, the protest groups recognized the right to the political subjectivity of all other Polish neighbors; d) the communist regime in Poland failed to deny the «moral status» and autonomy of the Catholic Church, so the election of Pope John Paul II only strengthened anti-communist antagonisms in Polish society and consolidated their working and intellectual resources and manifestations ${ }^{14}$.

The results of such a signaling of Poland's experience influenced primarily Hungary, where negotiations of protest/opposition socio-political movements and the communist regime began shortly after the «round table» in Poland. On the other hand, protest groups in Hungary were much weaker than in Poland, as they never felt strong enough to speak «on behalf of society» and negotiate «compromise democratization» with representatives of the «old regime». Accordingly, the Hungarian «oppositionists» have resorted to a strategy of uncompromising, that is, to demanding free elections as a mechanism for legalizing political protest. In this context, it is interesting that the first protest/opposition socio-political movements in Hungary, as well as in Poland, began to take shape in the late 1970s. - first

9 Bruszt L., Stark D. Remaking the Political Field in Hungary: From the Politics of Confrontation to the Politics of Competition. Banac I. Eastern Europe in Revolution. Ithaca: Cornell University Press, 1992. P. 13-71.

${ }^{10}$ Ackerman P., Duvall J. A Force More Powerful. A Century of Nonviolent Conflict. New York: St. Martin's Press, 2000. 544 p.

${ }^{11}$ Prizel I. National Identity and Foreign Policy. Nationalism and Leadership in Poland, Russia, and Ukraine. Cambridge University Press, 1998. P. 103.

12 Snyder T. The Polish-Lithuanian commonwealth since 1989: national narratives in relations among Poles, Lithuanians, Belarusians and Ukrainians. Nationalism and Ethnic Politics. 1998. Vol. 4. No. 3. P. 5.

${ }^{13}$ Curp T. The politics of ethnic cleansing: The P.P.R., P.Z.Z., Wielkopolska nationalist revolution, 1944-1946. Nationalities Papers. 2001. Vol. 29. No. 4. P. 588.

${ }^{14}$ Sonntag S. Poland. Pollack D., Wielgohs J. Dissent and opposition in communist Eastern Europe: origins of civil society and democratic transition. Ashgate, 2004. P. 18. 
of all, from dissident groups. However, quantitatively, structurally, organizationally, ideologically and typologically, the Hungarian protest or opposition was much smaller than the Polish one, and therefore was able to be systematized only in the second half of the 1980s. Moreover, the protest in Hungary was characterized by the fact that it concentrated mainly around large cities, above all Budapest, and for the most part, not the workers, but the intellectuals of the liberal and social democratic ideological orientation. However, the biggest difference between the Hungarian protest / opposition and the Polish one was that it was strongly supported or at least not denied by the reformist wing of the Communist Party. This played a crucial role in promoting civil society in Hungary in the late 1980s. ${ }^{15}$. The situation in this country began to resemble Poland when the phenomena of the socioeconomic crisis emerged, and in particular, in 1987, several rather influential networks of independent initiatives, independent trade unions and environmental movements were created at once ${ }^{16}$. The most influential were the populist-nationalist Hungarian Democratic Forum (MDF, 1987), the liberal Union of Free Democrats (SzDSz, 1988) and the nationalconservative Fidesz (1988). However, in general, the protest / opposition socio-political movements in Hungary (which were almost immediately transformed into parties) remained not very influential for some time. Instead, they were significantly stimulated by the reformist wing of the Hungarian Communists, which catalyzed the restoration of civil society in the country. On this basis, at the end of 1987, the communist regime began informal negotiations with official mass organizations created by protest / opposition groups as well as new reform groups ${ }^{17}$. As a consequence and in view of the political influence of Poland, the roundtable negotiations in June 1989 regulated the first fully free parliamentary elections in the spring of 1990. The victory was firmly won by a coalition of parties led by the Hungarian Democratic Forum, which was able to get more votes than other post-protest and post-communist parties - SzDSz, Fidesz, the Hungarian Socialist Party (MSZP) (reformed communists), etc. ${ }^{18}$.

As regards Czechoslovakia, protests / opposition socio-political movements were extremely weak and dispersed in this country (especially in

15 Gati C. Reforming Communist Systems: Lessons from the Hungarian Experience. Griffith W. Central and Eastern Europe, The Opening Curtain. Boulder, CO: Westview Press, 1989. P. 235-236.

${ }^{16}$ Urban L. Hungary in Transition: The Emergence of Opposition Parties. Telos. 1989. Vol. 79. P. 115.

${ }^{17}$ Hankiss E. In Search of a Paradigm. Daedalus. 1990. Vol. 119. No. 1. P. 205.

${ }^{18}$ Bozöki A. Post-Communist Transition: Political Tendencies in Hungary. East European Politics and Societies. 1990. Vol. 4. P. 228-229. 
the Czech and Slovak units). This was conditioned by years of repression by the communist regime in the aftermath of the Prague Spring in 1968. However, one of the attempts to form protest social and political movements took place in the late 1970s in the form of Charter 772 and the Committee on the Protection of the Unjustly Persecuted Persons ${ }^{19}$, but these expressions of protest were positioned on the brink of dissidence and opposition. On the other hand, the renewal of the influence of civil society was not caused by mass demonstrations under the auspices of protest groups, but by means of mobilization influence in the public groups. This happened in the late 1980s, when the atmosphere of fear and repression in Czechoslovakia began to decline as a result of a change in party leadership and the beginning of «perestroika» in the USSR, and as a result public demonstrations. It was as a result of the crackdown on one of these demonstrations involving students in Prague on November 17, 1989 that a «velvet revolution» against the communist regime began in Czechoslovakia ${ }^{20}$. As a result of such processes, organizations were formed in the Czech and Slovak part of the federal state (which did not have the status of socio-political movements, although formally / legally), such as the Civic Forum (OF) and the Society against Violence (VPN, respectively). Altogether, this determines that due to the relative weakness of the Czechoslovak opposition and limited «public space», democratic change was only possible if protest groups and organizations were able to direct spontaneous, unorganized and mass demonstrations by the far-flung parties from the far-flung party. Thus, civil society in Czechoslovakia was restored only after the "public space» had been «seized» by a spontaneous popular uprising, which allowed the opposition to be mobilized against the party-state. It is because of this logic of the event that the communist regime not only negotiated with protest groups and the public, but in fact escaped power.

It is worth noting that in these countries protest social and political movements and organizations, especially in the period from the second half of the 70's of the XX century and until 1987-1990, they acted as «agents» of anti-communism and anti-authoritarianism, because they fought first and foremost any manifestations and later remnants of the communist regime. Also, summarizing the peculiarities and tendencies of the formation and existence of socio-political movements in Poland, Hungary and Czechoslovakia, it is obvious that they were averagely characterized by

${ }^{19}$ Skilling G. Czechoslovakia Between East and West. Griffith W. Central and Eastern Europe, The Opening Curtain. Boulder, CO: Westview Press, 1989. P. 256.

${ }^{20}$ Wolchik S. Czechoslovakia's «Velvet Revolution». Current History. 1990. Vol. 89. No. 551. P. 413-416, 435-437. 
certain common and distinct attributes. The common attributes or patterns of protest socio-political movements in the region were the following tendencies: the attachment directly to illegal or semi-illegal protest groups of the communist political regime during its political and socio-economic crisis and the «perestroika»; postulation as a «debt» due to the influence of the anti-communist repressive-intolerant apparatus of the mobilization resistance and opposition to the political regime; appeals to issues of pre-communist nature - for example, national and ethnic sociopolitical divisions - that have persisted in the political culture of civil societies of the communist period; appeals to strategies for reforming «real socialism» regimes, in particular the construction of dogmatic and alternative socialism and social democracy, taking into account the traditions of the interwar period; articulation as «alternative» issues of peace and environmental protection ${ }^{21}$; positioning in the form of a «protest market» based mainly on trade unions and NGOs, concentrated more around urbanized rather than regulated areas; organization in the form of mobilization resistance to communist economic, social and cultural structures ${ }^{22}$, as well as based on historical and existing socio-political divisions and integrative norms and values (in the form of protest culture).

It is also noteworthy that the confrontation between the communist regimes and political protest groups in the region was quite similar, as the conflicting or rival parties/groups (communist power and anti-communist opposition) were interconnected in the fact that they could not solve the political crisis without help and assistance influence of each other - that is, they could not unilaterally impose the desired solution for each other if they really wanted to satisfy their different interests. Accordingly, in different countries at different times (for example, in Poland and Hungary predominantly until 1987, and in Czechoslovakia until 1989), including on the basis of fears of social and political upheaval, the need to construct a new one was clearly recognized social compromise «or» anti-crisis pact «by leading politicians and actors of the communist regime and anti-communist protest/opposition. Accordingly, it was the agreed form of peaceful interaction between the communist government and the anti-communist opposition that was the defining concept and strategy for the interaction of these forces. There were two explanations for this: first, the representatives of the protest groups believed that a revolution and any other form of violent political change could only lead to the emergence of another repressive

${ }^{21}$ Bugajski J., Pollack M. East European Fault Lines. Dissent, Opposition and Social Activism. Boulder, San Francisco, London: Westview Press, 1989. P. 200-217.

${ }^{22}$ Tilly C. From Mobilization to Revolution. Addison-Wesley, 1978. P. 35-40. 
political regime; second, they argued that violent political changes could not only jeopardize the possibility of a democratic order, but also undermine the chances of preserving human rights.

For the Communist parties, «pact» and «non-violence» were relevant in view of their desire to remain in power at least in part, because: on the one hand, their position on protest groups meant the official recognition of the right to form and operate groups that were always perceived by the regime's supporters as «enemies» and constantly suppressed; on the other hand, supporters of the «old regime» relinquished monopoly political power, guided by fear and «ghosts» of «white terror» by oppositionists. Overall, according to L. Bryusht, this means that the Communist parties were expecting the implementation of at least one of the two political strategies: a)»defense mobilization» in the form of controlling «top» political negotiations, preserving the role and status of communist parties, and «freezing» the balance of political forces with a tendency to block the emergence of other protest / opposition groups; b) separation of powers on the basis of a compromise between Communist parties and protest organizations, on the basis of which the former would be positioned as moderately authorized and moderately responsible parts of the coalition political process, alongside the latter. In turn, protest/opposition sociopolitical movements have «sacrificed» their moral and political authority and the concept of the so-called «new evolutionism». Moreover, protest movements were not decisively convinced that negotiations and compromise with the communist regime necessarily and utterly should have meant the collapse of the latter, and therefore they were in "constant fear» of radicalizing political protest / opposition in different countries of the region, and especially in Poland ${ }^{23}$.

It is also noteworthy that anti-communist socio-political movements were of varying influence - for example, weaker in Czechoslovakia, but stronger in Poland and Hungary - and lasting - for example, most tested in Poland, much less in Hungary, and least in Hungary in Czechoslovakia which is why they have led to different scenarios of the collapse of the communist regime and transit to democracy. At the same time, as D. Pollak and G. Eckert point out, the collapse of the «real socialism» regimes was influenced not only by the successes of protest anticommunist socio-political movements, but also by the "Gorbachev factor» and "perestroika» in the Soviet Union, by the fragmentation of Soviet power elites in the beginning. in the mid-1980s, the destructive impulse of the «surge in the Soviet empire»

${ }^{23}$ Siedlecki M. Time for Positive Action. East European Reporter. 1989. Vol. 3. No. 4. P. 35 . 
and more. Or, in other words, the collapse of communism in the region was systemically conditioned and accidental, because it was caused by both endogenous and exogenous factors, one of which was the increase in the influence and success of protest socio-political movements ${ }^{24}$.

It should also be noted that three key factors configured variations at first to change and subsequently to the collapse of «real socialism» regimes in contemporary Visegrad countries: the mobilization of the general population and civil society in particular; the ability of protest / opposition groups to act; the level of cohesion of the communist leadership and the quality of its response to the crisis of the system. These factors, in sum, generated two models of the impact of political protest on the collapse of «real socialism» regimes. According to the first model inherent in Czechoslovakia, the key factors of the communist crisis were not the role of protest/opposition groups, and the impact of the mobilization of the public and the inability to respond adequately to the individual (especially loyal) parts of the disintegrated consequences of the socio-economic crisis of the elite «old regime». Accordingly, socio-political movements / counter-attacks, which were also often not ready for diffuse and spontaneous manifestations of population mobilization, were able to act in response to the «vacuum» of political power, which was «warmed» by the sentiment of civil society (such a model of political protest influence averaged referred to as «implosion» or «replacement»). Instead, according to the second model, which was typical for Poland and Hungary, the main factors of the crisis of communism were the confrontation of some (especially reformist) facts of the Communist parties and political protest / opposition groups, which were «warmed up» by the influence of mobilization activities in the public / community environment. In view of this, the collapses of the «real socialism» regimes have taken place unplanned and unjustified, but as attempts to modify them partially, in particular to neutralize partially hardline supporters in the environment of communist parties and prevent the escalation of social and political conflicts.

\section{General characteristics of the consequences of protest socio-political movements in the Visegrad countries}

The consequences of the transformation of protest socio-political movements and organizations into political opposition (as a form of political

24 Ettrich F. Die «Zerstörung des Zerstörten» (Hegel). Der Zusammenbruch des Sozialismus sowjetischen Typs als sozialwissenschaftliches Problem. Brussig M., Ettrich F., Kollmorgen R. Konflikt und Konsens: Transformationsprozesse in Ostdeutschland. Leske, Budrich, Opladen, 2003. P. 231. 
protest) in Poland, Hungary and Czechoslovakia (Czech Republic and Slovakia) were the following: the practice of functioning as a determinant communist political system was discontinued and the systematic transformation of the state started; the process of democratization has begun in the form of involvement in the political process of legalized opposition configurations; the social expenditures system has been liberalized for different ways and variants of representation of social and political, including protest, interests; institutional mechanisms for guaranteeing public participation and representation in the socio-political process and public administration have been formed and tested ${ }^{25}$. As a result, in particular, on the basis of roundtables between representatives of the communist regime and protest socio-political movements in 1989, the region eventually began transformational processes, which were accompanied by the expansion of the sphere of protest, and consequently the expansion of the demands and goals of the socio-political movements. These changes, in turn, affected the further acceleration and variation of the dynamics of mass mobilization of political protest, as the collective actions of representatives of political protest / opposition groups began to be more frequent and drastic.

All this is incorporated in the fact that it is from the late 80's - early 90's of the XX century (and peaked in 1989-1993) and to this day civic activism in the modern countries of the Visegrad Group has started to be and still is an important element of political culture and a catalyst for institutional politics incorporated in the institutionalization of relations between the authorities and the opposition ${ }^{26}$. The manifestation of this was that, directly from the results of the impact of socio-political movements and the general public on the collapse of the communist regime, any existing conflicts between institutionalized political actors, in particular the government and parliamentary and non-parliamentary (generally political) opposition, can easily oppose the opposition and enhance the political role of protest. And in general, it is argued that the influence of protest socio-political movements and organizations on the formation of political opposition and the collapse of the regimes of «real socialism» in the modern countries of the Visegrad Group generated the perception of the phenomenon of socio-political protest as legal, institutionalized and non-political part of culture actions in the region $^{27}$. On this basis, M. Scabo argues that socio-political / political protest

${ }^{25}$ Szabo M. Some Lessons of Collective Protests in Central European Post-Communist Countries: Poland, Hungary, Slovakia, and East Germany Between 1989-1993. East Central Europe. 2000. Vol. 27. No. 1. P. 59-75.

${ }^{26}$ Ekiert G., Kubik K. Contentious politics in new democracies: East Germany, Hungary, Poland, and Slovakia, 1989-1993. World Politics. 1998. Vol. 50. No. 4. P. 554.

${ }^{27}$ Ibid, P. 554. 
in the form of opposition movements and organizations during and after the period 1987-1990 began to position itself as a central element in changing the political regime and consolidating the new political system in the Visegrad Group countries.

At the same time, an important role in defining the attributes of functioning of protest socio-political movements and organizations in the modern countries of the Visegrad Group, in particular through the prism of their opposition to the communist regimes, was to take into account how these movements and organizations developed further - mainly before and after the first democratic (constituent) parliamentary or presidential elections. In this section, it is clear that the first (constituent) elections played the role of a «springboard in the form of a referendum», in which protests and opposition communist movements and organizations demonstrated their formal anticommunist orientation and a far-sighted prospect of democratic reform and transformation. At the same time, given the Western political tradition and civilizational progress, to which the opinions of apologists of the processes of democratization by the forces of socio-political movements and organizations in all analyzed countries were «tied,» their further political discourse simply could not take place in structured or unstructured ones, but established organizational framework. It had to be defined and determined by more specific institutional procedural mechanisms. Accordingly, this specificity has been decisive in the transformation of protest socio-political movements and organizations in the party, which, as experience shows, have become the primary agents of transformation and, in particular, the institutionalization of political opposition, in the modern countries of the Visegrad Group not only in the way of their democratization, but and on the path of their integration into the EU.

The initial transformation of protest socio-political movements and organizations into political parties in the analyzed countries took place in 1989-1993, or in the period between the preparation for the first democratic (constituent) and the first multi-party (in the sense of political party participation) elections (namely in this period Czechoslovakia transformed into the Czech Republic and Slovakia, and soon the newly formed Visegrad Group began to be referred to as four countries).

Analytically and comparatively, such dynamics are crucial for several reasons. First of all, given that all of these countries have previously been or are currently being evaluated as consolidated or semi-consolidated democracies, so taking into account the experience of forming political parties in them is important for constructing / refining the theory of 
democratic transit ${ }^{28}$. Secondly, given the fact that the different dynamics of the processes of these protest socio-political movements and organizations have differently influenced their future positioning and delineation of the essence of political opposition within the different systems that emerged on the place of communist regimes.

For this reason, comparative analysis of the transformation of protest socio-political movements and organizations into political parties, as well as the failures of this process in individual countries, should be carried out in a constant and close mutual relation to such indicators as political activity at the level of movements, organizations and parties, organizational experience and attributes of the political (in the context of democratization and democracy) regime. Such correlation is needed to answer the question of why some protest movements and organizations, including the umbrella structures, led to the emergence of stable institutionalized systems with influential parties, while others led to the fragmentation and organizational weakness of political parties and party systems. In practical terms, this is as follows: why, for example, the powerful Polish «Solidarity» protest movement with deep rootedness in society could not form any stable or successful political party that would remain in power during the postcommunist period, or why Hungary's relatively weak divided, small and isolated opposition protest groups have been able to form parties that are centralized, resilient, and widely supported.

To address this range of issues in the context of political opposition, scientific evidence has been taken as a basis to show that the formation of parties and party systems in Poland, Slovakia, Hungary and the Czech Republic, especially in terms of their stability and institutionalization, are based on electoral features of the political process and attributes of existing socio-political divisions. They are, as M. Duverger points out, determined how party systems are fragmented, structured and stable. In addition, it is noted that all the socio-political divisions that existed in Poland, Hungary, the Czech Republic and Slovakia from the late 1980s to the mid-1990s were not as significant as expected theoretically. On the other hand, previous studies of the influence on the party systems of the countries of the region of the phenomena of the ideological concentration of electorates of different polities $^{29}$ played a significant role in evaluating the attributes of the transformation of protest socio-political movements and organizations in the

28 Кольцов В. Методологічний інструментарій дослідження демократичного транзиту. Актуальні проблеми філософії та соиіології. 2016. № 10. С. 65-67.

${ }^{29}$ Horowitz S., Browne E. Sources of Post-Communist Party System Consolidation: Ideology Versus Institutions. Party Politics. 2005. Vol. 11. No. 6. P. 689-706. 
party in 1989-1993 or the duration and consequences of the different perspectives of political transit initiated by political elites in the sample of countries analyzed ${ }^{30}$. Moreover, it is also important that the leading role in the fact that protest/opposition movements and organizations successfully or unsuccessfully transformed into the party was primarily played by political elites and strategies that incorporated them into various determinative moments of political transit.

Another indicator of the causality of the protests transformation by the communist regime of socio-political movements and organizations into political parties, as well as the independent (separate) formation of political parties in post-communist Poland, Hungary, the Czech Republic and Slovakia (Czechoslovakia), was influenced by the peculiarities of historical development and particularity, reflection in the determinations of the political process of the late 80 's - early 90's of the XX century. In this context, according to the opinion of A. Gzymalo-Buss, the processes of transformation of communist parties of «real socialism» regimes into other political forces in the conditions of formation and consolidation of democracy were important and additional to the formation of political opposition. The fact is that in the act of transformation of the former communist parties of Poland, Hungary and Czechoslovakia some procedural refinements were concealed to the case analyzed in our context: if the decline and / or restoration of communist parties depended on the history of communist political forces until 1989, then it could not arising from the transformation of the protest / opposition groups of the communist regime also had to be explained by the historical attributes of the development of such groups (which is the focus of the previous section of the study). Therefore, it is advisable to check the extent to which the organizational legacy and genesis of protest socio-political movements and organizations influenced the ways and features of the formation, development and imitation of party competition in the future (especially in the early 1990s).

In this case, two research positions and strategies are important: 1) an examination of how likely protest / opposition movements were in Poland, Hungary and Czechoslovakia earlier than 1989; 2) checking the level of antagonism between the communist regime and protest / opposition movements until 1989. In view of this, we consider that the evaluation of the listed factors, positions and strategies is effective in explaining the factors that influenced the effectiveness or inefficiency of the processes of transformation of protest / opposition socio-political movements and

${ }^{30}$ Reich G. Coordinating Party Choice in Founding Elections: Why Timing Matters. Comparative Political Studies. 2001. Vol. 34. No. 10. P. 1237-1263. 
organizations into political parties in the countries that are now members of the Visegrad Group. Moreover, this marker is also important in assessing the institutionalization of party systems, which is an indirect manifestation of the institutionalization of political opposition (which will be discussed in detail in the following sections of the study).

In this context, it should be noted that there can only be two research positions. The first assumes that there is a «well-organized» and «strong» opposition or protest movement that is in antagonistic relations with the authoritarian communist regime, and this is quite sufficient reason and motivation for a consolidated position in the conditions of his (this movement) transformation into a strong political party during the postcommunist phase of the development of a certain polity. However, there are a number of comments on this, which, for example, boil down to the case that was peculiar to the communist and post-communist stages of Poland's development. The fact is that in this country, as noted above, there was a very powerful and popular solidarity-based anti-communist protest movement that failed to transform itself into a single strong political party. The second position, however, argues that this is not exceptional and not even surprising, because by organizational structure such (as in Poland) movement had to be transformed into a number of not necessarily strong parties with sufficiently powerful representative capabilities. This was due primarily to the breadth of interests that had been incorporated into the social base of "Solidarity». The reason for this is that the protest / opposition movement had deep roots in civil society, a large number of sympathizers and a tradition of mass membership ${ }^{31}$. And unlike and in justifying the second scientific position, parties that emerged from Hungarian anticommunist protest, as noted by D. Stark, were labeled as having no deep connection with elements of civil society. Accordingly, the examination of the outlined cases shows that in fact they were united by the opposite: a) «Solidarity», which suffered a significant loss of membership after the collapse of the communist regime, completely «dissolved» into incoherent fragments that did not resemble that of the «Solidarity» movement that existed in 1989; b) organized, but much weaker, Hungarian political protest / opposition, which faced a much milder communist regime, «spawned» at least two significant «post-opposition» (analyzed) political parties; c) In the Czech Republic, for example, the relatively weak anti-communist opposition, which had virtually no capacity to grow organizationally and combinatively into a solid political structure under the brutal communist

\footnotetext{
${ }^{31}$ Grabowski T. The Party That Never Was: The Rise and Fall of the Solidarity Citizens' Committees in Poland. East European Politics and Societies. 1996. Vol. 10. No. 2. P. 214-254.
} 
regime in Czechoslovakia, was almost completely transformed into a group of «technocrats-reformers» in the post-communist period of $1989^{32}$. On the basis of such experience it is concluded that it is appropriate to combine different practical components and theoretical and methodological perspectives of transformation of protest / opposition socio-political movements and organizations into political parties, since it allows comparing the preconditions of political-legal status with political connection and its connection the process of democratization in the region. Moreover, it regulates that the process of transformation of protest sociopolitical movements and organizations in the party should be discussed in a multifactorial and cross-thematic manner, in the form of a case-stage and regional comparisons, etc. ${ }^{33}$.

Let's start with the analysis of individual cases, because they allow us to identify as political protest to the communist regimes in each of the analyzed countries, transforming into official political opposition, poured into the process of forming new political parties and even generating new party systems. And then let's look at the patterns of transformation processes cross-thematically and regionally, which will reveal additional analytical similarities and differences.

We start chronologically from the case of Poland, the only country in the region where protests of social and political movements, especially the «Solidarity» trade union movement, gained organizational significance and became mass organizations with a considerable opportunity to exert pressure on the communist regime by the end of the 1980s. (and in particular, in the case of «Solidarity», in 1980-1981.). However, in this case, the «fate» of «Solidarity» after the 1989 parliamentary elections is of particular interest. Exploring it, we proceed from the fact that, being a larger organization of social-democratic ideological orientation, it consisted of micro-groups united solely by the idea that Poland should be an independent democratic country. Accordingly, in the wake of the 1989 elections, it became a parliamentary faction, and internal organizational conflicts began to emerge and intensify in the «Solidarity» environment, causing the organization to lose electoral support $^{34}$. It lasted until December 1990, when the first national elections of

\footnotetext{
${ }^{32}$ Innes A. Czechoslovakia: The Short Goodbye. New Haven: Yale University Press, 2001. $334 \mathrm{p}$.

${ }^{33}$ Кольцов В. Роль політичної опозиції у краху режимів «реального соціалізму» в сучасних країнах Вишеградської групи (70-80 роки XX ст.). Вісник національного технічного університету Украйни «Київський політехнічний інститут». Серія: Політологія. Соиіологія. Право. 2016. № 3-4 (31-32). С. 154-157.

${ }^{34}$ Cockerham W. Health and Social Change in Russia and Eastern Europe. Routledge, 1999. P. 157.
} 
the President of Poland took place, the victory of which was won by Lech Wałęsa. As a result, in February 1991, M. Krzaklewski was elected leader of «Solidarity». It is because of this vision of the future post-protest / post-opposition movement on the part of Lech Wałęsa and the new leadership of the organization that diverged, on the basis of which Solidarity began to position itself as a political force of parliament, increasingly critical of the government.

As a result, in order to participate in the 1991 parliamentary elections, it was decided to transform «Solidarity» into a party of the same name ${ }^{35}$. But as a result of elections determined by a large number of competing political forces, many of which appealed to the legacy of post-communism, «Solidarity» (S) received only $5.1 \%$ of the vote (or 27 seats in the Seim) ${ }^{36}$. In 1992, the party attempted to confront a government created by democratic parties: first, a one-hour and later a two-hour strike against the government cabinet. And in May 1993, "Solidarity» MPs proposed to declare a noconfidence vote and promoted the resignation of the coalition government by Kh. Sukhotska, which in turn ended with the announcement of early parliamentary elections. But according to their results, «Solidarity» did not get seats in the Seim (winning $4.9 \%$ of the vote at the five percent barrier) ${ }^{37}$. The paradox is that, with no other option, «Solidarity» began to cooperate with its former adversary, the Polish Trade Union Alliance (OPZZ). However, in the 1995 presidential election, «Solidarity» supported Lech Wałęsa candidacy.

This is the sole story of the "Solidarity» Party. However, in 1996, more than 30 Liberal, Conservative and Christian-Democratic forces formed the «Electoral Action of Solidarity» (AWS), a political party in the form of an electoral coalition. In 1997, the party was renamed the «Solidarity of Right Electoral Action» (AWSP). In 1997-2001, the political force was the largest in parliament and twice participated in the formation of government offices (led by E. Buzek). But because of the failures of Poland's development, corruption problems, internal contradictions in the electoral coalition, as well as the failure of the last one in the 2001 parliamentary elections, the «Solidarity»-based party received no mandate (winning $5.6 \%$ voters' votes, which was not enough formally to win the electoral coalition mandate). After that, the party departed from the political process, and subsequently its

${ }^{35}$ Kubicek P. Unbroken Ties: The State, Interest Associations, and Corporatism in PostSoviet Ukraine. Michigan: University of Michigan Press, 2000. P. 188.

${ }^{36}$ Nohlen D., Stöver P. Elections in Europe: A data handbook. Baden-Baden: Nomos Verlagsgesellschaft Mbh \& C., 2010. P. 1491.

${ }^{37}$ Ibid. 
dissolution. As a result, only one organization, called «Solidarity», continued to operate in Poland, a trade union that originates directly from the anti-communist socio-political movement and the trade union.

Another vector of the development of the anti-communist organization «Solidarity» and its transformation into political parties in the late 1980s and early 1990s was the focus and concentration of sympathizers and members of the socio-political movement around, above all, such individuals as Lech Wałęsa and B. Geremek. Back in 1988, they formed the basis for the formation of the semi-legal (up to 1989) Civic Committee «Solidarity» (or Civic Election Committee), which was represented in the Seim by the results of the "partially free» constituent parliamentary elections of 1989. In June 1989, the Parliamentary Civic Party (OKP) was formed on its basis. But due to the controversy, two structures were isolated from the parliamentary faction: 1) the conservative populist wing, on the basis of which the Party «Center`s Consent» (PC) emerged, led by L. Kaczynski; 2) the liberalintellectual wing that formed the «Civic Movement for Democratic Action» $(\mathrm{ROAD})$, which after some time joined three distinct parties - the «Democratic Union» (UD), the «Freedom Union» (UW) and the «Democratic Party» (PD). The most obvious division within «Solidarity» was during the 1990 presidential election campaign: the conservatives supported Lech Wałęsa and the liberals T. Mazowiecki. It is interesting that such division, although partly conditional, continues still to exist in Polish party politics. Thus, the transformation of «Solidarity» into a party in Poland did not significantly affect the generation of the current state of the party system, although it facilitated the competition and institutionalization of political opposition at the beginning of democratization processes.

In Hungary, political protest groups were not endowed with the same considerable organizational unity / depth as in Poland, but managed to form themselves in the late 1980s. Despite the fact that dissidence and other protests in Hungary, in particular in the 70's - early 80's of the twentieth century were virtually invisible, the deepening economic crisis in the mid to late 80 's of the twentieth century and the weakening of the communist regime as it sought ways out of the crisis, generated considerable space for opposition activity ${ }^{38}$. As a consequence, in the late 80 's of the twentieth century the selected groups of independent intellectuals began to form organizations with specific requirements and alternative political and economic proposals for reform.

38 Jenkins R. Stabilizing the Democratic Transition: The 1990 Hungarian Parliamentary Elections. Rutgers. URL: http://hi.rutgers.edu/szelenyi60/jenkins.html. 
The first of these is the Hungarian Democratic Forum (MDF), which appeared in 1987 on the basis of the tacit consent of supporters of the communist regime's reforms. The MDF grouped different writers and intellectuals from the national populist movement, who focused on the need for national and moral renewal, as well as on the rights and status of ethnic Hungarian minorities in neighboring countries. Soon this organization was transformed into a political party of the same name, which ideologically positioned itself as a center-right liberal-conservative and Christiandemocratic movement ${ }^{39}$. The party from 1990 to 2010 was represented in the national parliament of Hungary. At the same time, the party's electoral successes were steadily diminishing: from the status of the primary in the coalition offices of J. Antal and P. Borosh (1990-1994) to the status of the additional one in the coalition government of V. Orban (1998-2002) (in other cases, the party positioned solely as opposition ${ }^{40}$. As a result of the 2010 parliamentary elections, the party did not receive representation in the Legislature (2.2\% of the vote) and subsequently turned into another electorally unpopular party - the «Democratic Community of Welfare and Freedom» (JESZ) - finally ceasing to operate in 2011.

Another post-protest/post-dissident organization that emerged in Hungary in 1988 is the «Union of Free Democrats» (SzDSz). This opposition structure was formed on the basis of the so-called «Democratic Opposition Movement» in Budapest (from which, in 1988, the «Network of Free Initiatives» was formed.). But soon, including the 1990 parliamentary elections, the group transformed into a liberal political party of the same name, the «Union of Free Democrats» ${ }^{41}$. What is interesting is that during 1990-2010 the party received support mainly from the population of Budapest. During the opposition to the communist political regime, the political party radically advocated a change in the political, economic and social system of the country. Unlike the «Hungarian Democratic Forum», the analyzed post-protest party was a long-running electoral and coalition ally of the post-communist «Hungarian Socialist Party» (MSZP). Accordingly, the «Union of Free Democrats» in 1994-1998 and 2002-2008 (unlike 1990-1994, when it had the status of the largest opposition party) positioned itself as the coalition partner of the «Hungarian Socialist Party».

39 Enyedi Z. The Survival of the Fittest: Party System Concentration in Hungary. Jungerstam-Mulders S. Post-communist EU Member States: Parties and Party Systems. Burlington: Ashgate, 2006. P. 177-202.

${ }^{40}$ Ramet S. Central and Southeast European Politics Since 1989. Cambridge University Press, 2010. P. 80.

${ }^{41}$ Hlousek V., Kopecek L. Origin, Ideology and Transformation of Political Parties: EastCentral and Western Europe Compared, Ashgate, 2010. P. 115. 
But after that there was a split in the relations between the parties. On average, in 1990-2010, electoral support for this post-protest party was steadily diminishing. As a result of the 2010 parliamentary elections, the party did not receive representation in the Legislature, and in 2013 it was dissolved altogether.

The third Hungarian post-protest organization, which also emerged in 1988, is Fidesz. In its origin, it relied on a democratic youth movement created by graduates of I. Bibo Law College. Ideologically during this period, it was a shift from the center-right to the right spectrum of the National Conservative Party ${ }^{42}$. Moreover, at the time of formation, given the position of the youth movement, it was necessary to speak about the libertarian anti-communist orientation of the party. This, according to P. Kende, was manifested in the fact that by 1993, the party's statute provided for the highest age limit of party members at the level of 35 years. However, since the mid 90's of the twentieth century (after the failure of the 1994 parliamentary elections) the party began to change its ideological orientation. Since then, it has gradually begun to acquire the features/attributes of technocratism, Hungarian nationalism, social conservatism, «soft» euroscepticism, national populism. In 1995, due to modernization, the name of the political party was changed / modified Fidesz / Hungarian Civic Party (Fidesz-MPSz). However, another interesting thing is that, being overwhelmingly opposition in the Hungarian Legislature, thereafter began a steady increase in the electoral success of the party (from $7.02 \%$ of the vote in 1994 to $52.73 \%$ of the vote in 2010 and $44.87 \%$ of the vote) voters in 2014.). As a consequence, in 1998-2002 and since 2010, the party has positioned itself as a government (V. Orbán's cabinets) and even dominant in the party system of Hungary (though in coalition with the Christian Democratic People's Party, KDNP).

Thus, in Hungary, three key protest groups prior to the roundtable negotiations in 1989 were able to develop their own programs and organizational structure in the form of political parties. As a result, the negotiations with the communist regime were characterized by internal and opposition power. It was on the basis of this specificity, in particular the influence of protest groups and parties, that in 1989 it was decided to hold a referendum, and in 1990 - the constituent parliamentary elections. In addition, on this basis, unlike Poland, the formation of post-protest parties took place in Hungary and, accordingly, the generation of organizational

${ }^{42}$ Szabo M. From a Suppressed Anti-Communist Dissident Movement to a Governing Party: The Transformations of Fidesz in Hungary. Corvinus Journal Of Sociology And Social Policy. 2011. Vol. 2. No. 2. P. 46-47. 
experience, which in the future had a positive impact on the functioning of parties and the party system of the country.

In the Czech Republic and Slovakia (initially within the Czechoslovakia), protest / opposition groups had significantly fewer opportunities to organize effectively themselves in political parties and movements. Although in the late 80's of the twentieth century, there was an increase in protest groups in the country ${ }^{43}$, they were usually positioned as poorly structured and insignificant in size (public support). In addition (given the strength of the communist regime discussed in the previous section of the study), such opposition / protest organizations have been severely repressed by the authoritarian regime.

This was evident in the case of the Czech part of Czechoslovakia that the formation of the Civic Forum (OF) - the main protest / opposition movement within the historical Czech Republic, which initiated the roundtable negotiations in Czechoslovakia and the collapse of the communist regime in this federation, could not have taken place until November 1989, when there was a brutal repressive suppression of the student demonstration in Prague, which led to the «velvet revolution». In this context, the specificity of the formation of the anti-communist protest / opposition movement in the Czech Republic was that the Civic Forum did not have the time and organizational capacity to develop itself (even in comparison with Hungary) just before the roundtable negotiations and to the point where he took political control of the country. This was due to the fact that in June 1990, when the first democratic (constituent) elections took place in the Czech Republic and Czechoslovakia, an organization that did not have a consolidated program of further development, but spoke exclusively about overcoming the communist regime, even though it received support of almost 50\% of Czech voters and more than $36 \%$ of Czechoslovakia's voters overall (with the KSCS succeeding in $13 \%$ of voters' support), but not positioned as a political party. And this is at a time when other political parties have already been formed or restored in the Czech Republic - the Movement for Autonomous Democracy - the Moravian and Silesian Party (HSD-SMS), the Christian and Democratic Union (KDU), etc. Moreover, the organizational non-solidarity of the movement emerged immediately after the 1990 voters, when a political confrontation broke out between V. Havel (leader of the Civic Forum, who was elected President of Czechoslovakia in 1989) and the formal leadership of the protest / opposition Civic Forum the person of J. Urban, and soon in

${ }^{43}$ Tůma O. Czechoslovakia. Pollack D., Wielgohs J. Dissent and opposition in communist Eastern Europe: origins of civil society and democratic transition. Ashgate, 2004. P. 38-40. 
the person of V. Klaus). As a result, protest / opposition unity became questionable and at the January 1991 congress of the Civic Forum, supporters of V. Klaus declared the need to form a new political force - the Civic Democratic Party (ODS). Throughout the post-communist history of the Czech Republic, to a lesser extent today, it is the largest conservative (liberal-conservative) and partly Eurosceptic center-right party of the Czech Republic (formally created in April 1991), modeled after the British Conservative Party ${ }^{44}$, but has in its structure political groups / factions of different ideological lines - social-conservative, national-conservative, neoconservative and national-liberal. At the same time, it is noteworthy that at the time of its formation, the Civic Democratic Party was positioned as a «pro-market» (liberal) political force, and in its development was characterized as a stable party, on the basis of which the Czech Republic's party system was institutionalized. This is manifested in the fact that the party is a permanent member of the Czech Parliament and periodically forms governmental (mostly coalition) cabinets. In 1992-1998, it was positioned as the largest parliamentary party and the dominant government party (the three coalition cabinets of V. Klaus and the coalition cabinet of J. Toshovsky). In 1998-2006, it was the largest opposition party in the Czech Republic (as opposed to the Czech Social Democratic Party, CSSD, dominant during this period). During 2006-2013 (except for the period 2009-2010), the party repositioned itself as the largest government (with 2006-2009 being the dominant government and the largest in parliament). However, since 2013 the electoral ratings of the party have worsened and it has transformed into an opposition one.

At the same time, another party in the Czech Republic emerged from the remnants of the Civic Forum in 1991 - the centrist liberal, social liberal, national liberal, and environmentalist $(\mathrm{OH})$ movement, which even in 19911992 even had representation at the level of several federal ministers. Thus, the protest / opposition movement organized in the short term in the Czech Republic successfully transformed itself into a party, first of all, into the ODS, which immediately became the basis for the institutionalization of this country's party system.

In the rest of the federal republic, and later in the independent state Slovakia - the development of the protest / opposition movement was similar.

At the same time, a centrist Liberal Democratic Party (ODU) was formed on the other part of the post-protest / post-opposition movement

${ }^{44}$ Hanley S. The New Right in the New Europe: Czech transformation and right-wing politics, 1989-2006. London: Routledge, 2008. P. 9. 
«Community against Violence», but a little earlier, including 1989, but it only existed until November 1992. According to analogy with the Czech Republic, only one post-opposition political party has succeeded in Slovakia, but it is still not represented in the national parliament today. Against this background, it is quite clear that protest / opposition movements were determinant in the formation and early stages of the party system in Slovakia.

\section{CONCLUSIONS}

Summarizing the attributes and logic of the formation and political influence of protest / opposition movements on the formation of parties and party systems in the modern countries of the Visegrad Group in 1989-2017, we can draw the following conclusions: a) the most politically (in particular by the result of constituent parliamentary elections) successful protest / opposition socio-political movements and organizations were in the Czech Republic and Hungary, and to a lesser extent in Poland and Slovakia; b) the largest number of socio-political movements, even those transformed into political parties that were represented in the national legislature, were in Hungary; c) the largest number of parties formed on the basis of protest / opposition movements was in Poland, slightly fewer in Hungary and the smallest in the Czech Republic and Slovakia; d) the most politically successful were political parties formed on the basis of protest / opposition movements in Hungary, less successful in Slovakia and the Czech Republic, and the least successful in Poland; e) parties that emerged from protest / opposition movements in the modern countries of the Visegrad Group were the most politically successful after the first (constituent) parliamentary elections, as well as in the first decade (90-ies of the XX century) after the collapse of the «real socialism» regimes. «And soon (except for the most part Hungary and to a lesser extent began to decline politically and even ceased to exist in some places; f) political parties formed on the basis of protest / opposition anticommunist socio-political movements are today (as of 2017) averagely marginalized or discontinued in Poland and Slovakia, much weaker than before in the Czech Republic, and very influential as before in Hungary; g) political parties formed on the basis of protest / opposition movements had the greatest influence on the formation and institutionalization of party systems in Hungary and the Czech Republic, as well as in their time (especially in the 1990s) in Slovakia, and to a lesser extent - in Poland; h) political parties that emerged on the basis of protest anticommunist socio-political movements did not become the exclusive descriptors and attributes of the party systems of the Visegrad Group 
countries, given that the political and legal status of political opposition in the region is determined by a number of other attributes.

Based on the use of multifactorial and cross-thematic regional comparisons, it is also clear that parties emerging from anti-communist political protest / opposition in the modern countries of the Visegrad Group were largely rooted in the late 1980s.

As for evaluating the transformational logic and prospects of turning protest / opposition socio-political movements into political parties, in particular on the basis of an analysis of the roles and motivations of key actors in the environment of anti-communist protest / opposition, it is clear that these were important people, in particular, in the sense that they played a prominent leadership role in social and political movements until at least 1989, and participated in negotiations with the communist regime on the prospects and features of creating democratic systems.

Therefore, in most countries, it is the protest / opposition anti-communist socio-political movements that transform into political parties (even regardless of how politically successful they are afterwards), that is, the phenomena and processes of socio-political protest and, in particular, opposition, proved to be the initials in the newest period of party building.

\section{SUMMARY}

The article deals with the phenomenon of protest socio-political movements and organizations and their transformation in the late 1980s on the example of the modern countries of the Visegrad Group. It has been determined that protest socio-political movements have been largely constructed on the logic and strategies of opposition resistance. It turned out that, relying primarily on the «forces» of society, for the first time in the conditions of «real socialism» regimes, they began to put pressure on political power and the party-state over how they functioned and were supposed to function. It was found that the three key factors that configured variations were first the changes and subsequently the collapse of the «real socialism» regimes in the modern countries of the Visegrad Group were: mobilization of the population at large and civil society in particular; the ability of protest / opposition groups to act; the level of cohesion of the communist leadership and the quality of its response to the crisis of the system. Based on the use of multifactorial and cross-thematic regional comparisons, it is also averagely evident that parties that emerged from anticommunist political protest / opposition in the modern countries of the Visegrad Group were largely rooted in the late 1980s. It has been proved that the most politically (particularly by the results of the constituent 
parliamentary elections) successful protest / opposition socio-political movements and organizations were in the Czech Republic and Hungary, and to a lesser extent in Poland and Slovakia, and the largest number of sociopolitical movements, even transformed in political parties that were represented in the national legislature were in Hungary.

\section{REFERENCES}

1. Ackerman P., Duvall J. A Force More Powerful. A Century of Nonviolent Conflict. New York: St. Martin's Press, 2000. 544 p.

2. Batt J. The End of Communist Rule in East-Central Europe. Government and Opposition. 1991. Vol. 26. No. 3. P. 368-390.

3. Bernhard M. Civil Society and Democratic Transition in East Central Europe. Political Science Quarterly. 1993. Vol. 108. No. 2. P. 307-326.

4. Bozöki A. Post-Communist Transition: Political Tendencies in Hungary. East European Politics and Societies. 1990. Vol. 4. P. 211-230.

5. Bruszt L. 1989: the Negotiated Revolution in Hungary. Social Research. 1990. Vol. 57. No. 2. P. 365-387.

6. Bruszt L., Stark D. Remaking the Political Field in Hungary: From the Politics of Confrontation to the Politics of Competition. Banac I. Eastern Europe in Revolution. Ithaca: Cornell University Press, 1992. P. 13-71.

7. Bugajski J., Pollack M. East European Fault Lines. Dissent, Opposition and Social Activism. Boulder, San Francisco, London: Westview Press, $1989.333 \mathrm{p}$.

8. Cockerham W. Health and Social Change in Russia and Eastern Europe. Routledge, 1999. 284 p.

9. Curp T. The politics of ethnic cleansing: The P.P.R., P.Z.Z., Wielkopolska nationalist revolution, 1944-1946. Nationalities Papers. 2001. Vol. 29. No. 4. P. 575-604.

10. Duverger M. Political Parties: Their organization and activity in the modern state. London: Methuen, 1954. 439 p.

11. Ekiert G. Democratization Processes in East Central Europe: A Theoretical Reconsideration. British Journal of Political Science. 1991. Vol. 21. P. 285-313.

12. Ekiert G., Kubik K. Contentious politics in new democracies: East Germany, Hungary, Poland, and Slovakia, 1989-1993. World Politics. 1998. Vol. 50. No. 4. P. 547-582.

13. Enyedi Z. The Survival of the Fittest: Party System Concentration in Hungary. Jungerstam-Mulders S. Post-communist EU Member States: Parties and Party Systems. Burlington: Ashgate, 2006. P. 177-202.

14. Ettrich F. Die «Zerstörung des Zerstörten» (Hegel). Der Zusammenbruch des Sozialismus sowjetischen Typs als 
sozialwissenschaftliches Problem. Brussig M., Ettrich F., Kollmorgen R. Konflikt und Konsens: Transformationsprozesse in Ostdeutschland. Leske, Budrich, Opladen, 2003. P. 215-254.

15. Gati C. Reforming Communist Systems: Lessons from the Hungarian Experience. Griffith W. Central and Eastern Europe, The Opening Curtain. Boulder, CO: Westview Press, 1989. P. 235-236.

16. Grabowski T. The Party That Never Was: The Rise and Fall of the Solidarity Citizens' Committees in Poland. East European Politics and Societies. 1996. Vol. 10. No. 2. P. 214-254.

17. Grzymala-Busse A. Redeeming the Communist Past: The Regeneration of Communist Parties in East-Central Europe. Cambridge: Cambridge University Press, 2002. 341 p.

18. Hankiss E. In Search of a Paradigm. Daedalus. 1990. Vol. 119. No. 1. P. 183-214.

19. Hanley S. The New Right in the New Europe: Czech transformation and right-wing politics, 1989-2006. London: Routledge, 2008. $292 \mathrm{p}$.

20. Hlousek V., Kopecek L. Origin, Ideology and Transformation of Political Parties: East-Central and Western Europe Compared, Ashgate, 2010. $263 \mathrm{p}$.

21. Horowitz S., Browne E. Sources of Post-Communist Party System Consolidation: Ideology Versus Institutions. Party Politics. 2005. Vol. 11. No. 6. P. 689-706.

22. Innes A. Czechoslovakia: The Short Goodbye. New Haven: Yale University Press, 2001. 334 p.

23. Jenkins R. Movements Into Parties: The Historical Transformation of the Hungarian Opposition. Program on Central and Eastern Europe Working Paper Series. 1992. No. 25. 80 p.

24. Jenkins R. Stabilizing the Democratic Transition: The 1990 Hungarian Parliamentary Elections. Rutgers. URL: http://hi.rutgers.edu/szelenyi60/jenkins.html.

25. Kende P., Smolar A. Die Rolle oppositioneller Gruppen am Vorabend der Demokratisierung in Polen und Ungarn (1987-1989). Köln, 1989. S. 64-93.

26. Kenney P. A Carnival of Revolution: Central Europe 1989. New Jersey: Princeton University Press, 2002. 341 p.

27. Kolakowski L. Hope and Hopelessness. Survey. 1971. Vol. 17. P. 42-48.

28. Kubicek P. Unbroken Ties: The State, Interest Associations, and Corporatism in Post-Soviet Ukraine. Michigan: University of Michigan Press, 2000. 275 p. 
29. Michnik A. The New Evolutionism. Survey. 1976. Vol. 22. P. 272-274.

30. Nohlen D., Stöver P. Elections in Europe: A data handbook. Baden-Baden: Nomos Verlagsgesellschaft Mbh \& C., 2010. 2070 p.

31. Pollack D. Politischer Protest. Politisch alternative Gruppen in der DDR. Opladen: Leske und Budrich, 2000. $282 \mathrm{s.}$

32. Prizel I. National Identity and Foreign Policy. Nationalism and Leadership in Poland, Russia, and Ukraine. Cambridge University Press, 1998. 443 p.

33. Rakovski M. Towards an East European Marxism. New York: St. Martin's, 1978. 139 p.

34. Ramet S. Central and Southeast European Politics Since 1989. Cambridge University Press, 2010. 600 p.

35. Reich G. Coordinating Party Choice in Founding Elections: Why Timing Matters. Comparative Political Studies. 2001. Vol. 34. No. 10. P. 1237-1263.

36. Siedlecki M. Time for Positive Action. East European Reporter. 1989. Vol. 3. No. 4.

37. Skilling G. Czechoslovakia Between East and West. Griffith W. Central and Eastern Europe, The Opening Curtain. Boulder, CO: Westview Press, 1989. $458 \mathrm{p}$.

38. Snyder T. The Polish-Lithuanian commonwealth since 1989: national narratives in relations among Poles, Lithuanians, Belarusians and Ukrainians. Nationalism and Ethnic Politics. 1998. Vol. 4. No. 3. P. 1-32.

39. Sonntag S. Poland. Pollack D., Wielgohs J. Dissent and opposition in communist Eastern Europe: origins of civil society and democratic transition. Ashgate, 2004. P. 3-28.

40. Stark D., Bruszt L. Postsocialist pathways: Transforming politics and property in East-Central Europe. Cambridge: Cambridge University Press, 1998. 284 p.

41. Szabo M. From a Suppressed Anti-Communist Dissident Movement to a Governing Party: The Transformations of Fidesz in Hungary. Corvinus Journal Of Sociology And Social Policy. 2011. Vol. 2. No. 2. P. 47-66.

42. Szabo M. Repertoires of Contention in Post-Communist Protest Cultures. Social Research. 1996. Vol. 63. P. 1155-1182.

43. Szabo M. Some Lessons of Collective Protests in Central European Post-Communist Countries: Poland, Hungary, Slovakia, and East Germany Between 1989-1993. East Central Europe. 2000. Vol. 27. No. 1. P. 59-75.

44. Tilly C. From Mobilization to Revolution. Addison-Wesley, 1978. 349 p. 
45. Tůma O. Czechoslovakia. Pollack D., Wielgohs J. Dissent and opposition in communist Eastern Europe: origins of civil society and democratic transition. Ashgate, 2004. P. 29-50.

46. Urban L. Hungary in Transition: The Emergence of Opposition Parties. Telos. 1989. Vol. 79. P. 108-118.

47. Wolchik S. Czechoslovakia's «Velvet Revolution». Current History. 1990. Vol. 89. No. 551. P. 413-437.

48. Кольцов В. Вплив протестних суспільно-політичних рухів і організацій на формування політичної опозиції в сучасних країнах Вишеградської групи (70-80 роки XX століття). Молодий вчений: науковий журнал. 2017. № 6 (46). С. 28-32.

49. Кольцов В. Методологічний інструментарій дослідження демократичного транзиту. Актуальні проблеми філософії та соиіологіï. 2016. № 10. С. 65-67.

50. Кольцов В. Роль політичної опозиції у краху режимів «реального соціалізму» в сучасних країнах Вишеградської групи (7080 роки ХХ ст.). Вісник національного технічного університету Украӥни «Київський політехнічний інститут». Серія: Політологія. Соиіологія. Право. 2016. № 3-4 (31-32). С. 154-157.

\section{Information about the author: Koltsov V. M.,}

$\mathrm{PhD}$ in Political Sciences, Associate Professor at the Department of Political Theories of the National University «Odessa Law Academy» 2, Academichna str., Odesa, 65009, Ukriane 
DOI https://doi.org/10.36059/978-966-397-158-2/271-290

\section{IMPACT OF CRIMEA'S ANNEXATION ON SECURITY POLICIES IN EUROPE: ADDRESING CHALLENGES AND MANAGING VULNERABILITIES BY THE EU AND VISEGRAD GROUP}

\section{Dvornichenko D.}

\section{INTRODUCTION}

Five years have passed since the Russian Federation annexed Crimea. The annexation of Crimea by the Kremlin turned out to be the most serious breach of European borders since the Second World War. Russia violated the fundamental principles of international law, its international obligations and bilateral agreements with Ukraine. The annexation has sharply increased instability of the European security environment, created new dividing lines and greatly enhanced the risk of the destruction of the existing world order. A proper understanding of how the annexation of Crimea affected Europe's security policy and shaped its response can provide essential insights to measure the effectiveness of its approach to ensuring the European security and preventing similar crises on a regional scale.

The following paper will assess how the annexation of Crimea affected the EU and its four member-states' policy. By taking an interdisciplinary and critical look at the impact the annexation of Crimea made on Europe, the paper aims to provide answers to the following questions:

1) How coherent and effective is the non-recognition, sanction-based and information security policy of the EU?

2) How has the annexation of Crimea impacted the narrative and political decisions in security field adopted by Russia understanders and Russia opponents among of the Visegrad Group?

3) How does the position of the EU and Visegrad Group contribute to the European security?

At the end of the paper the conclusions and recommendations on how to ensure Europe's own political, energetic and information security are presented.

\section{The Annexation of Crimea: Background and Implications}

The strategic importance of the Crimean peninsula was realized thousands of years ago. Its geopolitical location almost in the centre of the 
Black Sea between the Caucasus and Southern Europe as well as the wealth of natural resources makes its strategically important. A significant portion of Russia's navy stationed in Sevastopol and the ethnic diversity of Crimea with the largest population of ethnic Russians within Ukraine and a strong Muslim minority of the Crimean Tatars turned it into the most sensitive issue in Ukraine-Russia relations which could easily explode.

At different times Crimea was owned by the Tauris, Cimmerians, Greeks, Scythians, Romans, Huns, Goths, Bulgarians, Tatars, Slavs and other peoples. Its history as part of the Russian Empire started in 1783 when Catherine the Great annexed it from the Ottoman Empire. In 1921, Crimea became the Crimean Autonomous Soviet Socialist Republic, part of the Soviet Union. Thirty-three years later, in 1954, Nikita Khrushchev transferred Crimea to Ukraine in a move hailed as a noble act on behalf of the Russian people. When Ukraine held a referendum in December 1991, $54 \%$ of the Crimean residents favoured the independence from the Soviet Union. It was a majority, but the lowest one found in Ukraine. Thus Crimea became part of independent Ukraine with significant autonomy including its own constitution and parliament. In 1997, Ukraine and Russia signed a bilateral Treaty on Friendship, Cooperation and Partnership, which formally allowed Russia to keep its Black Sea Fleet in Sevastopol. From 1997 to 2014, the situation in Crimea was considered under control.

However, the second decade of the XXI century has marked a shift in Russian military mindset. A refusal to accept Western dominance alongside with a more active form of resistance has been deeply embedded in a new doctrine articulated by Chief of Russian General Staff Valery Gerasimov in his article «The Value of Science is in the Foresight». Based on the lessons of the Georgia conflict, he described a framework of the new operational concept as the role of «Non-Military Methods in the Resolution of Interstate Conflicts» ${ }^{1}$. According to V. Gerasimov, Russia heavily relies on proxy forces, both paramilitary and cyber, supported by media institutions and companies, Spetsnaz and Cossack fighters to conduct different types of operations, like unconventional, information, psychological and cyber operations, as well as security forces assistance and strategic communication. Due to the fact that the proxy forces consist of a mixture of Russians and ethnic Russians abroad, Russia not only exploits social conditions, but also cultural and linguistic factors in former Soviet states and

1 Герасимов В. Ценность науки в предвидении. Военно-Промышленный Курьер. 2013 // www.vpk-news.ru/articles/14632 
at home to create proxy forces ${ }^{2}$. The open use of forces often under the guise of peacekeeping and crisis regulation is resorted to only at a certain phase, primarily for the achievement of final success in the conflict. Altogether, the new generation warfare concept by V. Gerasimov has six phases which proved to be a successful approach in taking over Crimea from Ukraine.

Main part in the operation orchestrated by Russia was the media campaign to gain support in Crimea and to isolate the government of Ukraine. Television and the Internet were the dominant news media in Ukraine. The Russian information campaign started with the comparison of the Ukrainian government and their Western allies to Nazis, gays, Jews and other groups of people that Russia claimed were part of the conspiracy ${ }^{3}$. Russia showed swastikas on billboards and in the media to compare the Ukrainian government to Nazi Germany. Russian media used past events to emphasize how aggressive NATO and the West were and how these powers violated agreements on NATO expansion into Eastern Europe.

The annexation of Crimea has serious implications for Ukraine and Europe in all areas. In the economic area, the annexation of Crimea and further Russia's military actions in Donbas led to the displacement of 1.5 million registered Ukrainians, who have become a challenge not only for Ukrainian economy but also for the neighbouring EU member-states. In the energetic area, the annexation of Crimea led to the breakdown of energetic ties between Ukraine and Russia which might pose a challenge to the energy security of the other European states benefitting from transit routes via Ukraine's and their territory. In the military area, Russia can now block the Black Sea Straits in the South-West strategic direction, using forces located on the Crimean peninsula. In the geopolitical area, the annexation of Crimea demonstrated that European states security might be also challenged by Russia.

Although the Crimean scenario is unlikely to be repeated in other European countries, Russia's efforts to interfere in their internal affairs (especially in those countries which either have Russian-speaking population or common energetic and economic interests) via disinformation campaigns with the purpose to destabilize the situation and challenge the unity of the EU will be more assiduous. That actualizes the search for a proper response of the EU to the Kremlin's actions against Ukraine's territorial integrity.

2 Selhorst T. Russia's Perception Warfare. Militaire Spectator. 2016 // https://www.militairespectator.nl/thema/strategie-operaties/artikel/russias-perception-warfare

${ }^{3}$ Yuhas A. Russian Propaganda over the Crimea and the Ukraine: How Does it Work? The Guardian of 17 March 2014 // https://www.theguardian.com/world/2014/mar/17/the The the Crimea-crisis-russia-propaganda-media 


\section{EU's Response to the Annexation of Crimea}

The EU has demonstrated its strong commitment to support Ukraine since 2014. The EU conclusions, high-level statements and declarations have been used to address actions against Ukraine's territorial integrity, human rights violations and the infringement of navigational rights in Ukraine's territorial waters.

The situation in Crimea was first addressed by the EU during the extraordinary meeting of the EU Heads of State on 6March, 2014. In the joint statement, the EU leaders condemned Russia's unprovoked violation of the Ukrainian sovereignty and territorial integrity and called on Russia to immediately withdraw its armed forces and allow immediate access for international monitors ${ }^{4}$.

The violation of Ukrainian sovereignty and territorial integrity has become the key message in the numerous EU documents especially when the attention of the international community shifted from Crimea to Eastern Ukraine. However, since the outbreak of war in eastern Ukraine, the EU has been rather vocal in its support of any negotiating format in regard to the conflict in Donbas, whereas the issue of Crimea remains non-negotiable. In this regard there are serious doubts as to the consistency of the EU's position towards the annexed peninsula as «the EU insists on dividing the two issues, Donbas and Crimea» and omitting «the Crimean case from the current discussions» ${ }^{5}$.

The human rights violations have also been a topic of consistently keen interest of the EU. Since the Russian attack against Crimea, the European Parliament has paid close attention to the situation of the Crimean Tatars. Meanwhile, the European Parliament resolutions adopted in 2014 only vaguely addressed the human rights-related activities. The rapidly developing territorial conflict overshadowed other concerns. Five years on from the illegal annexation of the Autonomous Republic of Crimea and the city of Sevastopol by the Russian Federation, the High Representative Federica Mogherini on behalf of the EU adopted the Declaration on the Autonomous Republic of Crimea and the city of Sevastopol which states that the human rights situation in the Crimean peninsula has significantly deteriorated. Residents of the peninsula face systematic restrictions of

\footnotetext{
${ }^{4}$ Extraordinary meeting of EU Heads of State or Government on Ukraine of 6 March 2014 // https://www.consilium.europa.eu/en/meetings/european-council/2014/03/06/

${ }^{5}$ Ivashchenko-Stadnik K., Petrov R., Rieker P., Russo A. Implementation of the EU's crisis response in Ukraine. EUNPACK working paper. 2018 // http://www.eunpack.eu/sites/ default/files/publications/2018-01-31\%20D6.3\%20Working\%20paper\%20on\% 20implementation \%20of\%20EU\%20crisis\%20response\%20in\%20Ukraine.pdf
} 
fundamental freedoms, such as freedom of expression, religion or belief and association and the right to peaceful assembly. The Declaration also confirms the grave violations of rights of the Crimean Tatars through the shutting down of the Crimean Tatar media outlets, the banning of the activities of the Mejlis, their self-governing body, and the persecution of its leaders and members of their community ${ }^{6}$. Unfortunately, the Declaration contains nothing but the EU expectations that Russia will reverse its decisions and end the pressure on the Crimean Tatar community.

The infringement of navigational rights in Ukraine's territorial waters has also appeared to be one of the topics in the declarations and resolutions initiated by the EU. On 24 October 2018, the European Parliament adopted the Resolution which expressed its very serious concern about the volatile security situation in the Sea of Azov and condemned the excessive stopping and inspection of commercial vessels, including both Ukrainian ships and those with flags of third-party states. ${ }^{7}$ The resolution had no effect on further Russia actions in the Sea of Azov and did not stop the Kremlin from using force a month later when Russian forces fired on and seized two Ukrainian gunboats and one tug after the Ukrainian vessels tried to pass under the Kerch Strait Bridge.

In December 2018, following the events of 25 November, the European Parliament adopted the resolution on the implementation of the EU Association Agreement with Ukraine. It strongly condemned the deliberate act of aggression by the Russian Federation against Ukraine on 25 November 2018 in the Kerch Strait and called on the EU and its Member States to close access to EU ports for Russian ships coming from the Sea of Azov if Russia did not re-establish freedom of navigation through the Kerch Strait and in the Sea of Azov. ${ }^{8}$

On 17 June 2019, the Council adopted the Conclusions on the Black Sea confirming again that the EU policy decisions and its non-recognition policy on the illegal annexation of Crimea are fundamental to the EU's approach to

\footnotetext{
${ }^{6}$ Declaration by the High Representative Federica Mogherini on behalf of the EU on the Autonomous Republic of Crimea and the city of Sevastopol of 17March 2019 // https://www.consilium.europa.eu/en/press/press-releases/2019/03/17/declaration-by-the-highrepresentative-federica-mogherini-on-behalf-of-the-eu-on-the-autonomous-republic-of-crimeaand-the-city-of-sevastopol/

${ }^{7}$ European Parliament resolution $\{2018 / 2870$ (RSP)) on the situation in the Sea of Azov of 24 October 2018 // http://www.europarl.europa.eu/doceo/document/RC-8-2018-0493_EN.html

${ }^{8}$ European Parliament resolution (2017/2283(INI)) on the implementation of the EU Association Agreement with Ukraine of 12 December 2018 // http://www.europarl.europa.eu/ doceo/document/TA-8-2018-0518_EN.html?redirect
} 
regional cooperation in the Black Sea area ${ }^{9}$. However, the document remains silent on what exactly the EU is willing to do about Russia's unlawful actions in the Kerch Strait.

The non-recognition policy is rather seldom introduced in isolation from other foreign policy instruments such as restrictive measures. Since March 2014, the EU has progressively imposed restrictive measures against Russia in response to the annexation of Crimea. The first set of restrictive measures was imposed in 2014 against 21 Russian and Ukrainian officials responsible for actions threatening Ukraine's territorial integrity. The same year the EU adopted a package of targeted economic sanctions which included a ban on imports of goods originating in Crimea or Sevastopol unless they have Ukrainian certificates; a prohibition to invest in the Crimea, a ban to buy real estate or entities in the Crimea, finance the Crimean companies or supply related services, a ban to invest in infrastructure projects in the following sectors: transport; telecommunications; energy, exploration and production of oil, gas and mineral resources; a ban on providing tourism services in the Crimea; a ban on exporting transport, telecommunications and resources to the Crimea; a ban on providing technical assistance, brokering, construction or engineering services related to infrastructure in the Crimea.

In late November 2018, a new Crimean crisis challenged the international community. Russian coast guard ships opened fire on a group of vessels of the Ukrainian Navy in international waters as they were leaving the Kerch Strait ${ }^{10}$. However, it took the EU almost 4 months to renew sanctions over actions on 15 March 2019 to add eight Russian officials to the list of those subject to restrictive measures in respect of actions undermining or threatening the territorial integrity, sovereignty and independence of Ukraine $^{11}$. On 20 June 2019, Council prolonged the restrictive measures introduced in response to the illegal annexation of Crimea and Sevastopol by Russia until 23 June 2020.

However, there are particular weak spots in the sanctions regime. The EU is not expected to only condemn the party of the conflict but rather demonstrate how much pain can be tolerated. According to Paul

\footnotetext{
${ }^{9}$ Council Conclusions on the EU's engagement to the Black Sea regional cooperation of 17 June 2019 // https://www.consilium.europa.eu/media/39779/st10219-en19.pdf

${ }_{10}$ Ukraine urges EU to impose new sanctions on Russia over attack near Kerch Strait. UNIAN. 26 November 2018, // https://www.unian.info/politics/10351809-ukraine-urgeseu-to-impose-new-sanctions-on-russia-over-attack-near-kerch-strait.html

${ }^{11}$ Ukraine: EU responds to escalation at the Kerch Strait and the Sea of Azov, and renews sanctions over actions against Ukraine's territorial integrity of 15 March 2019 // https://www.consilium.europa.eu/en/press/press-releases/2019/03/15/ukraine-eu-responds-toescalation-at-the-kerch-straits-and-the-azov-sea-and-renews-sanctions-over-actions-againstukraine-s-territorial-integrity/
} 
Kalinichenko, the EU sanctions in response to the actions threatening Ukraine's territorial integrity and Russia's countersanctions have frozen negotiations and consequently have not achieved anything. ${ }^{12}$ The sanctions have neither stopped the annexation nor restrained Russia from taking further aggressive steps.

Besides, tighter implementation is required. In 2015 and 2016, Siemens sold gas turbines to Russia, four of which were later installed in Russiaannexed the Crimea. In May 2018, the construction of Nord Stream 2, which will deliver gas to Europe from northern Russia's Yamal Peninsula, started. Vessels from several EU member states have repeatedly infringed the sanctions by docking in the Crimean ports. The sanctions remain rather soft and thus fail to destroy the relations between the EU and Russia in such areas as energy, investments and manufactured goods trade.

Last but not least, most sanctions have been imposed in regard to such violations of international law as actions against Ukraine's territorial integrity, although breaches of human rights have been present so far. The EU addresses human rights violations by adopting particular conclusions and declarations rather than deploying restrictive measures. Hopefully, after the adoption of the EU Global Human Rights Act further sanctions in response to human rights violations in Crimea will be considered.

The annexation of Crimea has forced the EU to reconsider its own its own security approach due to new challenges and threats. Since 2014 Russia has been active in influencing public opinion and justifying its actions in Ukraine in 2014 by means of cyber activities. On the one hand, these activities, mainly but not exclusively expressed through cyberattacks, are targeted at the EU institutions and the governments of the European Union member-states. On the other hand, the citizens of the European states are also one of the targets of the Russia's cyber actions such as dissemination of propaganda and disinformation.

Since 2014 the EU has taken active measures to reduce its internal vulnerabilities in response to hybrid warfare, in the face of the challenges from Russia's disinformation and propaganda. The European Parliament in November 2016 adopted a resolution stating that «Russia's goal is to distort truths, provoke doubt, divide member states, engineer a strategic split between the European Union and its North American partners, discredit the EU institutions and transatlantic partnerships as well as to undermine and erode the European narrative based on democratic values, human rights and

12 Kalinichenko P. Post-Crimean Twister: Russia, the EU and the Law of Sanctions. Russian Law Journal. 2017. No 5(3). P. 9-28 // https://doi.org/10.17589/2309-8678-2017-53-9-28 
the rule of law» ${ }^{13}$. In 2017, The Council agreed to develop a framework for a joint EU diplomatic response to malicious cyber activities, the «cyber diplomacy toolbox» ${ }^{14}$. On 17 May 2019, the Council adopted the Council Decision (CFSP) 2019/797 concerning restrictive measures (sanctions) «to deter and respond to cyber-attacks which constitute an external threat to the EU or its member states, including cyber-attacks against third States or international organisations» ${ }^{15}$.

As Moscow is doing its best to deliver «the same disinformation stories in as many languages as possible through as many channels as possible ${ }^{16}$, the EU has also taken formal steps towards tackling this issue. The European security experts have appealed to the EU High Representative, Federica Mogherini to start taking the Russian disinformation threat seriously in 2015. ${ }^{17}$ Later that year, the European Council asked the EU High Representative for an action plan regarding strategic communication targeting Russia's ongoing disinformation efforts ${ }^{18}$. These actions resulted in the establishment of the East StratCom task force, set up in 2015 under the European External Action Service (EEAS). StratCom collects examples of pro-Kremlin false information articles in Europe and issues its weekly newsletters on the platform «EU vs Disinfo». As «EU vs Disinfo» sees the fight against disinformation as an extension of the EU's common foreign and security policy in the East, it is concentrated primarily against Russian propaganda efforts, especially in Ukraine, and the Russian state media's reporting on the EU. The task force has an additional task and aims also at promoting the European Union's policies mostly in the EU's eastern

\footnotetext{
${ }^{13}$ European Parliament Resolution of 23 November 2016 on EU Strategic Communication to Counteract Propaganda against it by Third Parties // https://www.europarl.europa.eu/ doceo/document/TA-8-2016-0441_EN.html

${ }^{14}$ Council Conclusions. Brussels on a Framework for a Joint EU Diplomatic Response to Malicious Cyber Activities of 7 June 2017 // http://data.consilium.europa.eu/doc/document/ST9916-2017-INIT/en/pdf

${ }^{15}$ Council Decision (CFSP) 2019/797 of 17 May 2019 concerning restrictive measures against cyber-attacks threatening the Union or its Member States // https://eurlex.europa.eu/legal-content/GA/TXT/?uri=CELEX:32019D0797

${ }^{16}$ Stone, J. 2018. Russian disinformation campaign has been 'extremely successful' in Europe, warns EU. Independent. 17 January 2018 // http://www.independent.co.uk/ news/uk/politics/russian-fakenews-disinformation-europe-putin-trump-eu-european-parliamentcommission-a8164526.html

${ }^{17}$ European Values. Open Letter of European security experts to Federica Mogherini: Please start taking the Russian disinformation threat seriously // http://www.europeanvalues.net/ mogherini/

${ }_{18}$ European Parliament. Disinformation, 'fake news' and the EU's response 2017. // http://www.europarl.europa.eu/RegData/etudes/ ATAG/2017/614584/EPRS_ATA(2017)614584_EN.pdf
} 
neighbourhood by addressing disinformation circulating within the EU that repeats Kremlin talking points. The latter is subject to harsh criticism as by meddling into the entire European information space and commenting on domestic media the European External Action Service's East Stratcom Task Force is increasingly emerging as a domestic censorship machine which goes far beyond the EEAS expertise.

In order to make the StratCom more effective, the European Parliament called for the development of «criteria for measuring the efficiency of its work and ensuring sufficient financing and adequate staffing of the East StratCom Task Force» ${ }^{19}$. The suggestion to provide adequate budgetary resources for the task force was highly welcomed as the team experienced sufficient difficulties with funding. Initially the East StratCom Task Force did not dispose its own budget but depended on the existing EU strategic communication budget. ${ }^{20}$

Further efforts were made in 2018, when the European Council endorsed the Action Plan against Disinformation which stated that the East StratCom Task Force analysed and put the spotlight on over 4,500 examples of disinformation by the Russian Federation. The same year, the Task Force was additionally granted $€ 1.1$ million for its work to address Russia's disinformation. In 2019, the budget increases to $€ 3$ million. From January 2019, the budget is being directed to ensure professional media monitoring, disinformation analysis and data analysis. The objective is to gain a more comprehensive, regular and reliable picture of Russia's disinformation campaigns $^{21}$.

\section{Security Policy of the Visegrad Group after the Annexation of Crimea}

The present study will focus on evaluating public statements and actions taken by the Visegrad Four with the aim to assess the impact of annexation of Crimea on their security policies and the level of their alignment with the official Brussels course.

${ }^{19}$ European Parliament resolution of 23 November 2016 on EU strategic communication to counteract propaganda against it by third parties // http://www.europarl.europa.eu/doceo/ document/TA-8-2016-0441_EN.html

${ }^{20}$ Benková L.. The Rise of Russian Disinformation in Europe. FOKUS. \#3. 2018 // https://www.aies.at/download/2018/AIES-Fokus_2018-03.pdf

${ }_{21}$ Questions and Answers about the East StratCom Task Force // https://eeas.europa.eu/headquarters/headquarters-homepage/2116/-questions-and-answersabout-the-east-stratcom-task-force_en 


\subsection{Security Policy of Poland after the Annexation of Crimea}

Poland has been at the forefront of the European response to Russia's aggression. Unlike other Visegrad Group states, condemnation of Russian actions against territorial integrity of Ukraine is seen on an all-country political scale, drawing criticism from the right, left, and centre. The annexation of Crimea increased fears towards Russia that have always been very strong in Poland. Naturally, Poland has shown full support to sanctions against Russia and non-recognition policy. The annexation of Crimea has also affected Poland's internal policies and its perception of Europe's security system.

Poland has been firm on abandoning Russian natural gas imports in favour of alternative import sources from Denmark and Norway. The LNG terminal focused on the imports from Qatar, Norway and the United States was put into operation in 2016. In 2018, Poland announced plans to revive the Baltic Pipe Project - construction of an underwater pipeline in order to pump Norwegian North Sea offshore gas $^{22}$.

Poland has also increased its military expenses from 1,6\% GDP in 2013 to 2,2\% in 2015. As a part of Operation Atlantic Resolve, American soldiers have been deployed in Poland along with tanks and heavy equipment ${ }^{23}$ serving as a response to the militarization of Kaliningrad Oblast. Since the annexation of Crimea Polish state leadership has redoubled efforts to convince their partners and allies in the West that the enhancement of NATO Eastern flank is a very urgent need. Polish diplomacy instigated a demarche oriented toward persuading the leading NATO powers that the cheapest and easiest manner to deter potential future Russian invasion on the Transatlantic Alliance is to deploy additional troops to the countries which are the most susceptible to invasion ${ }^{24}$.

The Concept of Defence of the Republic of Poland adopted in 2017 considers the «aggressive policy of the Russian Federation, including the use of such tools as disinformation campaigns against other countries» as

\footnotetext{
${ }^{22}$ Miroslavov O. Poland refuses LNG terminal in favor of the gas corridor with Norway. RuBaltic. 6 March 2018 // https://www.rubaltic.ru/articles/06032018-poland-refuses-lngterminal-in-favor-of-the-gas-corridor-to-norway/

${ }^{23}$ Kremlin Watch Report. How do European democracies react to Russian aggression? Review of shifts in strategic \& policy documents of EU28 following Russian aggression against Ukraine. 2017// https://www.europeanvalues.net/wp-content/uploads/2017/04/How-doEuropean-democracies-react-to-Russian-aggression.pdf

${ }^{24}$ Furgacz P. Poland's Military Security Policy in the Context of the Russian Ukrainian War: Change or Continuity, Ante Portas - Studia nad Bezpieczeństwem, 2017. No $1 / /$ file:///D:/\%D0\%97\%D0\%B0\%D0\%B3\%D1\%80\%D1\%83\%D0\%B7\%D0\%BA\%D0\%B8/AP.V III_Furgacz\%20(1).pdf
} 
one of the main threats and challenges. However, the Concept does not contain any precise developments or tasks regarding information security. Meanwhile, the same year Polish Prime Minister Beata Szydło announced the creation of a department of cyber security within the Chancellery of the Prime Minister ${ }^{25}$.

Fight against Russian information influence has become a topic of regular discussions. In 2015, Poland started to draft the Cyber-security Doctrine of Republic of Poland as a response to the increase in hybrid threats, propaganda, disinformation, and psychological influence operation. The Doctrine is supposed to be the key document clarifying the scope of responsibilities and the mode of cooperation and coordination between the government, private institutions, and citizens. The document is still in the drafting phase.

In March 2017, the Polish Ministry of Digital Affairs published the draft Cyber Security Strategy for the years 2017-2022 as an extensive update of the 2013 edition. On 7 August, 2019, it was replaced by the Poland's Cybersecurity Strategy for 2019-2024.

Polish authorities publicly recognise the disinformation operations from Russia and consider them as a major threat at the national and international level $^{26}$. Among the most prominent steps in this field are the cancellation of the broadcasting license of the Warsaw-based station Radio Hobby that rebroadcasted programming produced in Polish by Radio Sputnik and the launch of the consultations on disinformation in Warsaw in 2016.

However, the civil society efforts in combatting Russia's disinformation are not so strong as in other Visegrad states. Poland is flourished by the nationalists and the groups that appeal to anti-immigrant sentiments, PolishUkrainian history or support the anti-Ukrainian demonstrations. Despite being marginalised, pro-Russian activists are getting more and more effective in spreading disinformation. Nowadays, the most vocal are the antiimmigrant groups. With the tacit consent from the government, the far-right nationalist groups act more freely and their activities are more visible to the general public. Setting up the Ukrainian flag on fire during the commemoration of Polish Independence Day in 2016 is the best example ${ }^{27}$.

25 Polish PM to set up new cybersecurity department. Radio Poland. 2017 // http://www.thenews.pl/1/9/Artykul/329562,Polish-PM-to-set-up-new-cybersecurity-department

${ }^{26}$ Minister Witold Waszczykowski opens conference on disinformation. MFA. 2016 // http://www.msz.gov.pl/en/news/minister_witold_waszczykowski_opens_conference_on_disinf ormation

${ }^{27}$ Milo D., Klingova K. Vulnerability Index: Subversive Russian Influence in Central Europe. GLOBSEC Policy Institute 2017 // https://www.globsec.org/wp-content/uploads/ 2017/08/globsec-vulnerability-index.pdf 
There are only a few NGOs monitoring the disinformation narratives in Poland and actively debunking them, e.g. CEPA has been producing weekly briefs on country-specific applications of Russian disinformation content and techniques and the effectiveness or weakness of propaganda.

\subsection{Security Policy of the Czech Republic after the Annexation of Crimea}

In the Czech Republic, several documents have been adopted to address the security issues after Crimea's annexation. The Security Strategy of the Czech Republic, adopted in 2015, warns about «threats of a military nature, stemming from the aspirations of some states that, more than ever, tend to show a disregard for the international order and basic principles of international law in their pursuit of power. Driven by such aspirations, these actors substantially reinforce their military capabilities, including offensive cyber capabilities. ${ }^{28}$ The document also mentions, that the Czech Republic includes among the relevant security threats also those that have no direct impact on its own security, but do threaten its allies.

In 2016, the Czech Government launched a process called «Audit of National Security», analysing 11 areas of internal security for blind spots in the security architecture «in context of events in Ukraine and with the emerging awareness that the Czech Republic has also been facing hybrid threats ${ }^{29}$. Among the 11 areas, there were two relevant for Russian influence: «Influence of Foreign Powers» and «Hybrid Threats». The Audit of National Security presented particular suggestions for strengthening the resilience of the Czech Republic such as the establishment of the Centre Against Terrorism and Hybrid Threats (CTHH) within the Ministry of Internal Affairs, a unit of 20 experts monitoring the spread of disinformation in the Czech media and disinformation campaigns in general, especially coming from Russia and the Islamic State. Its task is to monitor the disinformation campaigns, send early warning alerts on politically relevant disinformation and train other parts of the state administration with special program focused on this threat ${ }^{30}$. The Audit also highlighted the need for creation of a system of education for public officials to make them more

\footnotetext{
${ }^{28}$ Security Strategy of the Czech Republic. Ministry of Defence \& Armed Forces of the Czech Republic. $2015 \quad / / \quad$ http://www.army.cz/images/id_8001_9000/8503/ Security_Strategy_2015.pdf

Disinformation Resilience in Central and Eastern Europe. Kyiv. 2018 // http://prismua.org/wp-content/uploads/2018/06/DRI_CEE_2018.pdf

${ }^{30}$ Milo D., Klingova K. Vulnerability Index: Subversive Russian Influence in Central Europe. GLOBSEC Policy Institute 2017 // https://www.globsec.org/wpcontent/uploads/2017/08/globsec-vulnerability-index.pdf
} 
resilient towards foreign influence, launching active media strategies for important democratic institutions or measures concerning media law ${ }^{31}$.

However, concerning the practical steps, there are a lot of gaps and insufficiencies. Although the existing documents describe the threat well, they are not focused enough on practical measures. The establishment of CTHH is the only recommendation which has been implemented so far by the state.

The Annual Report of the Security Information Service for $2016^{32}$, an intelligence institution active within the Czech Republic, states that the Czech Republic is one of the primary targets of Russian hybrid campaign in the context of the Ukrainian crisis. As a part of subversive activities aimed against the sovereignty and territorial integrity of Ukraine, Russia and its intelligence services coordinated and financed operations of so-called nongovernmental organizations, which conducted grey and black active measures against territorial integrity of Ukraine. Representatives of «nongovernmental» entities directly or indirectly controlled by Russia and its intelligence services systematically attempted to gain support of Czech parliamentary and non-parliamentary political parties and officials from top state administrative authorities. The report also mentions APT28/Sofacy campaign which is currently the most visible Russian cyberespionage campaign with various areas of activities - ranging from principal areas, such as diplomacy and defence, to science and research and academia. The Security Information Service attributed the responsibility for attacks against Czech military research institution and several European Foreign Affairs Ministries in European states to APT28/Sofacy.

In the last couple of years, a few civil society projects and initiatives have been established to ensure the resilience of Czech society in the context of disinformation campaigns. The Czech think-tank European Values issues weekly newsletter the Kremlin Watch. The Association for International Affairs together with StopFake.org launched a Czech version of StopFake website. Another fact-checking initiative is project 'Demagog' whose primary goal is to teach the public to think critically about information provided by anybody as well as to raise awareness about the fact that disinformation can be used in public space. The launch of successful initiatives aimed at active monitoring of the influence of the disinformation and Russian propaganda has become possible due to the well-established and

31 National Security Audit. Government of the Czech Republic. 2016 // https://www.vlada.cz/assets/media-centrum/aktualne/Audit-narodni-bezpecnosti-20161201.pdf

32 Annual Report of the Security Information Service of the Czech Republic. 2016 // https://www.bis.cz/public/site/bis.cz/content/vyrocni-zpravy/en/ar2016en.pdf 
active civil society in the Czech Republic which according to the Vulnerability Index $2017^{33}$ ranked as the second most resilient towards the foreign influence.

\subsection{Security Policy of Slovakia after the Annexation of Crimea}

Slovakia does not consider Russian influence a threat, therefore, does not securitize disinformation campaigns and does not give a priority to strategic counter-measures. Besides, a «pragmatic» approach of Slovakia's leadership who regards Russia as an inevitable, unavoidable partner upon which Slovakia's economic development is dependent does not contribute to take adequate steps in combatting Russia's propaganda.

In this regard, there is no surprise, that in Slovakia, no specific document has been adopted to address the issue of security since 2005. The Slovak National Security Strategy was developed in 2005 and has not been updated since then. As such, it reflects the security threats existing at the time of its creation and the post $9 / 11$ era.

Currently, a new National Security Strategy has been drafted. The document claims that the security environment has deteriorated significantly due to the rising ambition of some states to the use of military force. It points to the specific manifestations of deteriorated security environment such as the promotion of foreign-political interests by some states and their use of military force to disrupt the territorial integrity of other states that is a direct reference to Russia ${ }^{34}$. It also emphasizes the negative impact of hybrid activities that both state and non-state actors can use to achieve specific goals without a formal declaration of war.

In this regard the most active forces in Slovakia in managing vulnerabilities are not the government but civil society. Slovak civil society ranked as the least vulnerable to external influence within the Visegrad Group $^{35}$ and the most active in addressing the influence of disinformation and Russian propaganda. A number of civic organizations and think tanks are currently taking the most visible countermeasures and activities in Slovakia. The annual Forum Against Propaganda (Fórum proti propaganda),

\footnotetext{
${ }^{33}$ Milo D., Klingova K. Vulnerability Index: Subversive Russian Influence in Central Europe. GLOBSEC Policy Institute 2017 // https://www.globsec.org/wpcontent/uploads/2017/08/globsec-vulnerability-index.pdf

${ }^{34}$ Nečej E., Žilinčík S. Analysis of the draft of Security Strategy of Slovak Republic 2017: Comparison with strategic documents of Czech Republic and Poland. STRATPOL. 2017 // https://www.stratpol.sk/wp-content/uploads/2017/08/fSSSR-2017-ENG-v-final-OND-final.pdf

${ }^{35}$ Milo D., Klingova K. Vulnerability Index: Subversive Russian Influence in Central Europe. GLOBSEC Policy Institute 2017 // https://www.globsec.org/wp-content/uploads/ 2017/08/globsec-vulnerability-index.pdf
} 
which is organized as a side event of the Slovak Security Forum, brings together individuals and organizations interested in the topic of disinformation from the public, private and NGO sectors. This platform serves as a place for the exchange of ideas and better coordination of joint efforts in counter measures. The GLOBSEC Policy Institute based in Bratislava issues Information War Monitor, analysing the narratives and disinformation spread in the Czech Republic, Hungary and Slovakia. The Slovak Security Policy Institute has been translating Disinformation Digest of EEAS' Strategic Communication Unit into Slovak language.

\subsection{Security Policy of Hungary after the Annexation of Crimea}

Hungary's latest document on its security policy, Governmental decree $1035 / 2012$, was adopted in $2012^{36}$. It neither mentions Russia not takes into account the new regional architecture of the international relations after 2014. Since then, the strategy has not been updated.

Hungarian Prime Minister Viktor Orban is considered the key political ally of the Kremlin who is sympathetic towards the behaviour of the Russian Federation and thus promotes the narratives used to justify Russia's occupation of the Crimea.

Hungary has two largest opposition parties, the socialist Magyar Szocialista Párt which is considered neutral, and the far-right Jobbik, which is openly pro-Russian. This is compounded by the strong economic ties between Hungary and Russia, especially in the energy sector, and the fact that the Hungarian government is openly critical to the EU sanctions on Russia.

There is no surprise, that according to the GLOBSEC Vulnerability Index, Hungary is the most vulnerable country in the Visegrad group to subversive Russian influence ${ }^{37}$. Although there are some efforts from the non-governmental organisations to manage the country's vulnerability to foreign influence (among which Political Capital is the most influential), there is no thematic debunking site in Hungary.

Hungary is not only reluctant to counteract Russia's threat but also actively deepens cooperation with it. The Russian disinformation centres are welcomed. In April 2017 Orban's government allowed Debrecen University to establish a Russkiy Mir Center, providing a EUR 50,000 grant ${ }^{38}$. There are also NGOs directly involved in spreading Russian views. Honfoglalás

\footnotetext{
${ }^{36}$ Hungary's National Security Strategy. 2012 // https://www.eda.europa.eu/docs/defaultsource/documents/hungary-national-security-strategy-2012.pdf

${ }^{37}$ Milo D., Klingova K. Vulnerability Index: Subversive Russian Influence in Central Europe. GLOBSEC Policy Institute 2017/ / https://www.globsec.org/wpcontent/uploads/2017/08/globsec-vulnerability-index.pdf

${ }^{38}$ KrekóP., Győri L. Hungary: A State Captured by Russia. Heinrich Böll Foundation. 2017 // https://www.boell.de/en/2017/10/11/hungary-state-captured-russia
} 
2000 and the Nationalist Social Democrats are Hungarian organizations supporting the government and its pro-Russian foreign policy, including the organisation of rallies supporting Russian-Hungarian friendship. Furthermore, both of these organizations were founded by the Friends of Vladimir Putin Circle. According to the press release, the Friends of Vladimir Putin Circle was established to «inform the population on the incredibly successful work of the Russian president ${ }^{39}$.

\section{CONCLUSIONS}

The annexation of Crimea by the Kremlin has become a test for the EU. So far the EU has managed to develop a non-recognition and sanction-based approach towards Russia's actions in Crimea. It has also made certain efforts in tackling Russia's propaganda and disinformation. However, there are certain doubts whether this response is really an effective means of deterrence. It has neither led to the return of Crimea to Ukraine nor stopped Kremlin's further aggressive actions in the Sea of Azov. The only consideration that occupies the minds of the EU officials is how to save the face and keep on implementing ambitious energy projects in collaboration with Russia. That reveals a number of weaknesses and hidden reputational risks in the EU's response to the security challenges in its nearest neighbourhood.

All the Visegrad Group states differ in how they define and address security threats. They experience current political regime changes, rely on different institutional and technical capacities, as well as develop distinct relationships with Russia. The security challenges management remains rather state-centralized in all four states. The engagement with civic society, research centres and private stakeholders is underdeveloped which results in their vulnerability to foreign, particularly Russia's, influence. Although the EU-level adopted documents as well as the launch of the East StratCom Task Force allow for a greater cooperation among the Visegrad Group states in tackling foreign influence, such initiatives are seriously challenged by domestic political regimes. In this regard, we can hardly expect an effective common approach to security in the region in the nearest future which is only beneficial for Moscow, which focuses on bilateral relations with particular Visegrad Group states and actively seeks to exploit differences between them.

The annexation of Crimea concerns the most basic principles of Europe and therefore should be considered in a much broader context as a test of endurance for it. The challenge for the EU member states is how to ensure

\footnotetext{
${ }^{39}$ Milo D., Klingova K. Vulnerability Index: Subversive Russian Influence in Central Europe. GLOBSEC Policy Institute 2017 // https://www.globsec.org/wpcontent/uploads/2017/08/globsec-vulnerability-index.pdf
} 
Europe's own political, energetic and information security. This task is not easy but therefore, the most important thing is to make sure that all the EU member-states follow the Brussels-based course. Firstly, Europe should draw certain red lines in relations with Russia and make it clear that their trespassing will not be tolerated. Secondly, the European states should have a common position and vision of what should happen to have sanctions lifted. Besides, the EU member states should consider the application of additional sanctions on Russia in response to human rights violations in Crimea and reputational sanctions for others who support Putin's aggressive behaviour. Thirdly, there should be more awareness on the need to cooperate in order to counter hybrid threats and any interference in the internal affairs of the European countries.

\section{SUMMARY}

The article deals with the assessment how the annexation of Crimea affected Europe's security policy. The research focuses on the EU's response to the annexation of Crimea, as well as examines the post-2014 security policy of the four countries which are the most susceptible to invasion and vulnerable to Russia's influence - Poland, Slovakia, the Czech Republic and Hungary. By taking an interdisciplinary and critical look at the impact the annexation of Crimea made on Europe, the paper aims to provide essential insights on how the annexation of Crimea has impacted the narrative and political decisions in security field adopted by EU and the Visegrad Group states. Several vulnerabilities and challenges to greater cooperation and common approach to security in the region at the EU level and the four member-states' level are identified. At the end of the paper the recommendations on how to ensure Europe's own political, energetic and information security are presented.

\section{REFERENCES}

1. Герасимов В. Ценность науки в предвидении. ВоенноПромыиленный Курьер. 2013. URL: www.vpk-news.ru/articles/14632

2. Annual Report of the Security Information Service of the Czech Republic. 2016. URL: https://www.bis.cz/public/site/bis.cz/content/vyrocnizpravy/en/ar2016en.pdf

3. Benková L. The Rise of Russian Disinformation in Europe. FOKUS. 2018. No 3. URL: https://www.aies.at/download/2018/AIES-Fokus_201803.pdf

4. Council Conclusions on the EU's engagement to the Black Sea regional cooperation of 17 June 2019. URL: https://www.consilium.europa.eu/media/39779/st10219-en19.pdf 
5. Council Conclusions. Brussels on a Framework for a Joint EU Diplomatic Response to Malicious Cyber Activities of 7 June 2017. URL: http://data.consilium.europa.eu/doc/document/ST-9916-2017-INIT/en/pdf

6. Council Decision (CFSP) 2019/797 of 17 May 2019 concerning restrictive measures against cyber-attacks threatening the Union or its Member States. URL: https://eur-lex.europa.eu/legal-content/GA/TXT/ ?uri=CELEX:32019D0797

7. Declaration by the High Representative Federica Mogherini on behalf of the EU on the Autonomous Republic of Crimea and the city of Sevastopol of 17March 2019. URL:https://www.consilium.europa.eu/en/press/pressreleases/2019/03/17/declaration-by-the-high-representative-federicamogherini-on-behalf-of-the-eu-on-the-autonomous-republic-of-crimea-andthe-city-of-sevastopol/

8. Disinformation Resilience in Central and Eastern Europe. Kyiv. 2018. URL: http://prismua.org/wp-content/uploads/2018/06/ DRI_CEE_2018.pdf

9. European Parliament resolution (2017/2283(INI)) on the implementation of the EU Association Agreement with Ukraine of 12 December 2018. URL: http://www.europarl.europa.eu/doceo/document/ TA-8-2018-0518_EN.html?redirect

10. European Parliament resolution $\{2018 / 2870(\mathrm{RSP}))$ on the situation in the Sea of Azov of 24 October 2018. URL: http://www.europarl.europa.eu/doceo/document/RC-8-2018-0493_EN.html

11. European Parliament Resolution of 23 November 2016 on EU Strategic Communication to Counteract Propaganda against it by Third Parties. URL: https://www.europarl.europa.eu/doceo/document/TA-8-20160441_EN.html

12. European Parliament. Disinformation, 'fake news' and the EU's response 2017. URL: http://www.europarl.europa.eu/RegData/etudes/ ATAG/2017/614584/EPRS_ATA(2017)614584_EN.pdf

13. European Values. Open Letter of European security experts to Federica Mogherini: Please start taking the Russian disinformation threat seriously. URL: http://www.europeanvalues.net/mogherini/

14. Extraordinary meeting of EU Heads of State or Government on Ukraine of 6 March 2014. URL: https://www.consilium.europa.eu/en/ meetings/european-council/2014/03/06/

15. Furgacz P. Poland's Military Security Policy in the Context of the Russian Ukrainian War: Change or Continuity, Ante Portas - Studia nad Bezpieczeństwem, 2017. No 1. URL: file:///D:/\%D0\%97\%D0\%B0\%D0\% B3\%D1\%80\%D1\%83\%D0\%B7\%D0\%BA\%D0\%B8/AP.VIII_Furgacz\%20( 1).pdf 
16. Hungary's National Security Strategy. 2012. URL: https://www.eda.europa.eu/docs/default-source/documents/hungarynational-security-strategy-2012.pdf

17. Ivashchenko-Stadnik K., Petrov R., Rieker P., Russo A. Implementation of the EU's crisis response in Ukraine. EUNPACK working paper. 2018. URL: http://www.eunpack.eu/sites/default/files/publications/ 2018-01-31\%20D6.3\%20Working\%20paper\%20on\%20

implementation\%20of\%20EU\%20crisis\%20response\%20in\%20Ukraine.pdf

18. Kalinichenko P. Post-Crimean Twister: Russia, the EU and the Law of Sanctions. Russian Law Journal. 2017. No 5(3). P. 9-28 . URL: https://doi.org/10.17589/2309-8678-2017-5-3-9-28

19. KrekóP., Győri L. Hungary: A State Captured by Russia. Heinrich Böll Foundation. 2017 . URL: https://www.boell.de/en/2017/10/11/hungarystate-captured-russia

20. Kremlin Watch Report. How do European democracies react to Russian aggression? Review of shifts in strategic \& policy documents of EU28 following Russian aggression against Ukraine. 2017. URL: https://www.europeanvalues.net/wp-content/uploads/2017/04/How-doEuropean-democracies-react-to-Russian-aggression.pdf

21. Milo D., Klingova K. Vulnerability Index: Subversive Russian Influence in Central Europe. GLOBSEC Policy Institute. 2017. URL: https://www.globsec.org/wp-content/uploads/2017/08/globsec-vulnerabilityindex.pdf

22. Minister Witold Waszczykowski opens conference on disinformation. MFA. 2016. URL:http://www.msz.gov.pl/en/news/minister_ witold_waszczykowski_opens_conference_on_disinformation

23. Miroslavov $\mathrm{O}$. Poland refuses $\mathrm{LNG}$ terminal in favor of the gas corridor with Norway. RuBaltic. 2018. URL: https://www.rubaltic.ru/ articles/06032018-poland-refuses-lng-terminal-in-favor-of-the-gas-corridorto-norway/

24. National Security Audit. Government of the Czech Republic. 2016. URL: https://www.vlada.cz/assets/media-centrum/aktualne/Auditnarodni-bezpecnosti-20161201.pdf

25. Nečej E., Žilinčík S. Analysis of the draft of Security Strategy of Slovak Republic 2017: Comparison with strategic documents of Czech Republic and Poland. STRATPOL. 2017. URL: // https://www.stratpol.sk/wp-content/uploads/2017/08/fSSSR-2017-ENG-vfinal-OND-final.pdf

26. Polish PM to set up new cybersecurity department. Radio Poland. 2017. URL: http://www.thenews.pl/1/9/Artykul/329562,Polish-PM-to-setup-new-cybersecurity-department 
27. Questions and Answers about the East StratCom Task Force. URL: https://eeas.europa.eu/headquarters/headquarters-homepage/2116/questions-and-answers-about-the-east-stratcom-task-force_en

28. Security Strategy of the Czech Republic. Ministry of Defence \& Armed Forces of the Czech Republic. 2015. URL: http://www.army.cz/ images/id_8001_9000/8503/Security_Strategy_2015.pdf

29. Selhorst T. Russia's Perception Warfare. Militaire Spectator. 2016. URL: https://www.militairespectator.nl/thema/strategieoperaties/artikel/russias-perception-warfare

30. Stone, J. 2018. Russian disinformation campaign has been 'extremely successful' in Europe, warns EU. Independent. 17 January 2018. URL: http://www.independent.co.uk/news/uk/politics/russian-fakenewsdisinformation-europe-putin-trump-eu-european-parliament-commissiona8164526.html

31. Ukraine urges EU to impose new sanctions on Russia over attack near Kerch Strait. UNIAN. 26 November 2018. URL: https://www.unian.info/politics/10351809-ukraine-urges-eu-to-impose-newsanctions-on-russia-over-attack-near-kerch-strait.html

32. Ukraine: EU responds to escalation at the Kerch Strait and the Sea of Azov, and renews sanctions over actions against Ukraine's territorial integrity of 15 March 2019. URL: https://www.consilium.europa.eu/ en/press/press-releases/2019/03/15/ukraine-eu-responds-to-escalation-at-thekerch-straits-and-the-azov-sea-and-renews-sanctions-over-actions-againstukraine-s-territorial-integrity/

33. Yuhas A. Russian Propaganda over the Crimea and the Ukraine: How Does it Work? The Guardian of 17 March 2014. URL: https://www.theguardian.com/world/2014/mar/17/the The the Crimea-crisisrussia-propaganda-media

\section{Information about the author: Dvornichenko D., $\mathrm{PhD}$ in Political Sciences,} Associate Professor at the Department of Maritime Law of the National University «Odesa Maritime Academy» 8, Didrikhson str., Odesa, 65029, Ukraine 
NOTES 
Publishing house «Liha-Pres»

9 Kastelivka str., Lviv, 79012, Ukraine

44 Lubicka str., Toruń, 87-100, Poland

Printed by the publishing house «Liha-Pres»

Passed for printing: November 12, 2019.

A run of 150 copies. 